Flooding in the United States Midwest, 2008

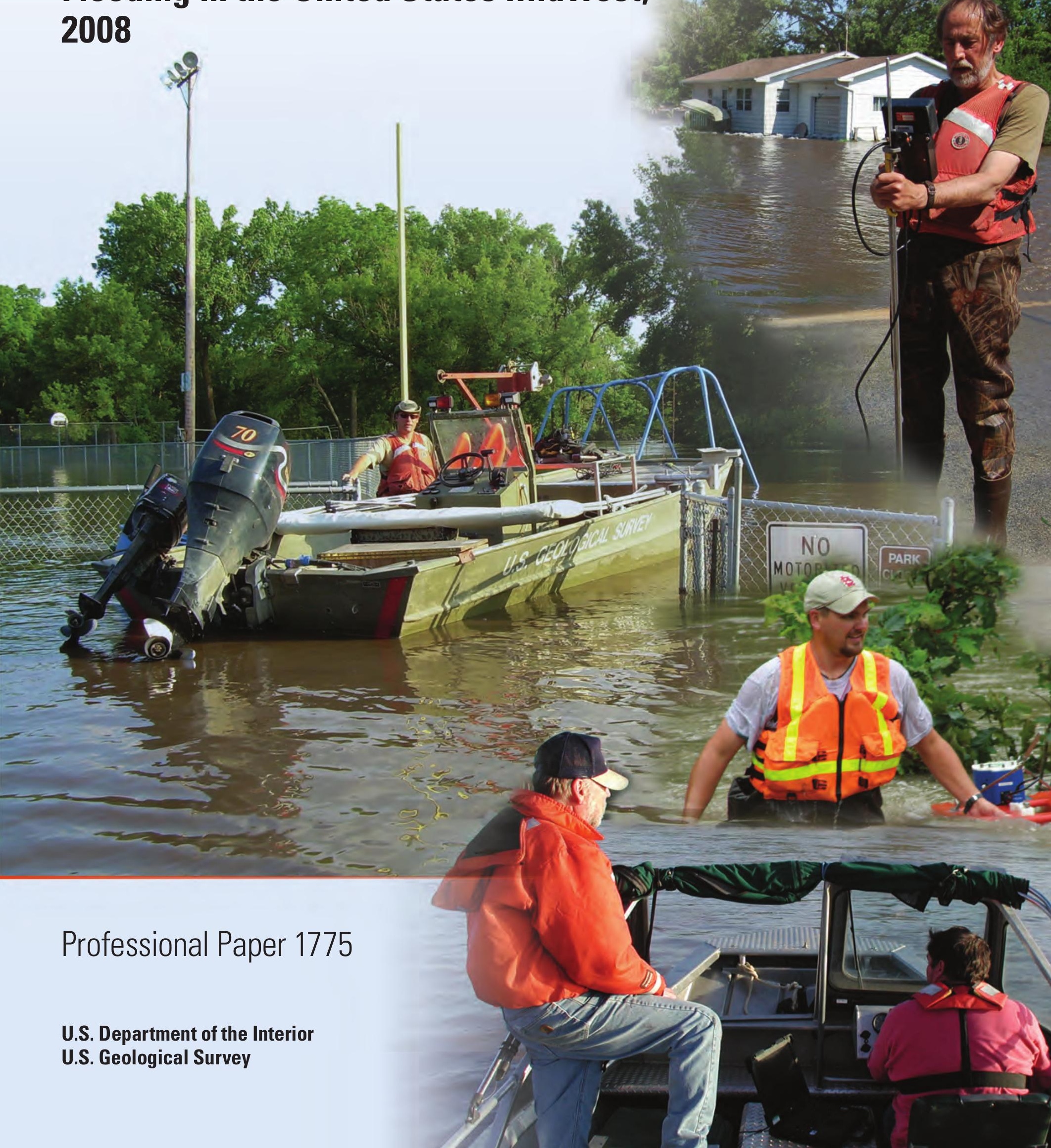




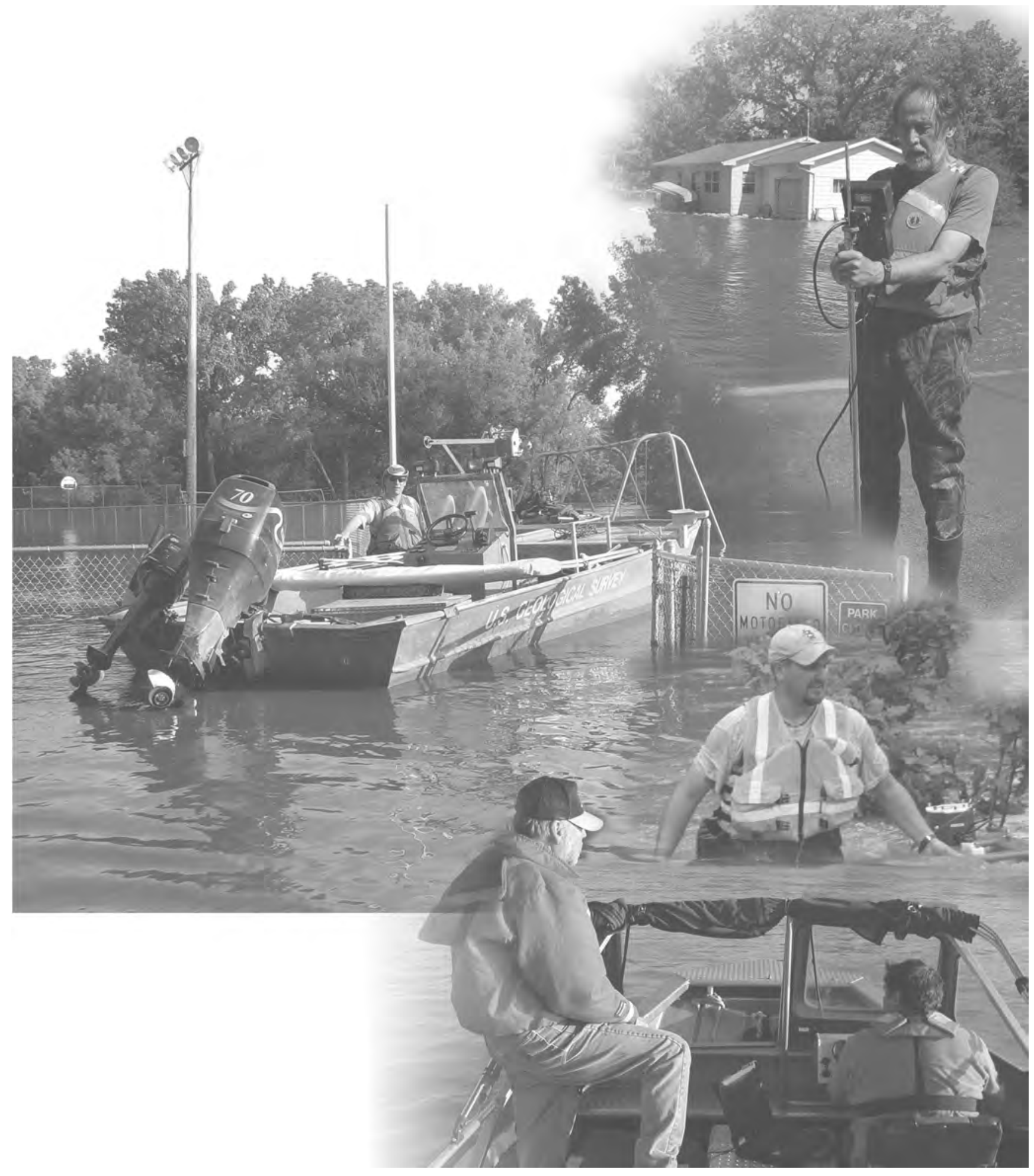

\section{Front cover.}

Left center: USGS personnel launching boat in Janesville, lowa park. Boat was used to access the streamgage on the Cedar River at Janesville, lowa (USGS streamgage 05458500). Photograph by Scott Strader, USGS.

Upper right: USGS hydrographer analyzing stream velocity data collected in the road overflow caused by West Fork Cedar Creek in Finchford, lowa (USGS streamgage 05458900). Photograph by Don Becker, USGS.

Center right: USGS hydrographer retrieving streamflow measurement instrument temporarily lodged in overbank trees on Long Branch Creek at Atlanta, Missouri (USGS streamgage 06906150). Photograph by C. Shane Barks, USGS.

Lower right: USGS hydrographers making a measurement of streamflow on the Gasconade River at Jerome, Missouri (USGS streamgage 06933500). Photograph by Richard Huizinga, USGS. 


\section{Flooding in the United States Midwest, 2008}

By Robert R. Holmes, Jr., Todd A. Koenig, and Krista A. Karstensen

Professional Paper 1775

U.S. Department of the Interior

U.S. Geological Survey 


\section{U.S. Department of the Interior KEN SALAZAR, Secretary \\ U.S. Geological Survey Marcia K. McNutt, Director}

\section{U.S. Geological Survey, Reston, Virginia: 2010}

For more information on the USGS - the Federal source for science about the Earth, its natural and living resources, natural hazards, and the environment, visit http://www.usgs.gov or call 1-888-ASK-USGS

For an overview of USGS information products, including maps, imagery, and publications, visit http://www.usgs.gov/pubprod

To order this and other USGS information products, visit http://store.usgs.gov

Any use of trade, product, or firm names is for descriptive purposes only and does not imply endorsement by the U.S. Government.

Although this report is in the public domain, permission must be secured from the individual copyright owners to reproduce any copyrighted materials contained within this report.

Suggested citation:

Holmes, R.R., Jr., Koenig, T.A., and Karstensen, K.A., 2010, Flooding in the United States Midwest, 2008: U.S. Geological Survey Professional Paper 1775, 64 p.

\section{Library of Congress Cataloging-in-Publication Data}

Holmes, Robert R., 1965-

Flooding in the United States Midwest, 2008 / by Robert R. Holmes, Jr., Todd A. Koenig, and Krista A. Karstensen. p. cm. -- (Professional paper ; 1775)

ISBN 978-1-4113-2841-9

1. Floods--Middle West. 2. Flood damage--Middle West. I. Koenig, Todd A. II. Karstensen, Krista A. III. Geological Survey (U.S.) IV. Title. V. Series: U.S. Geological Survey professional paper ; no. 1775.

GB1399.4.M6H65 2010

$551.48^{\prime} 90978^{\prime} 090511--d c 22$ 


\section{Contents}

Glossary

Abstract.

Introduction.

The Role of the U.S. Geological Survey in Flood Response

2008 Flooding: Causes, Chronology, and Magnitude

Antecedent Conditions for the 2008 Midwest Flooding

Chronology and Magnitude of Flooding: January through September 2008

2008 Flooding: Comparison with Historic Floods

2008 Flooding: Annual Exceedance Probability

Effects of the 2008 Flooding on Annual Exceedance Probability Estimates

Trends in Flood Maxima.

Summary.

References Cited

Tables 1-7.

\section{Figures}

1. Map showing the United States Midwest and general areas of flooding streams, January to September, 2008

2. Photograph showing U.S. Geological Survey hydrographer measuring streamflow on the Platte River near Sharps Station, Missouri (USGS streamgage 06821190), with an acoustic Doppler current profiler (ADCP) mounted to a tethered boat to collect velocity and depth readings that are sent by radio link to a laptop computer inside the field vehicle

3. Graph showing changes in the rating curve for the Platte River near Kearney, Nebraska (USGS streamgage 06770200), as a result of on-site direct streamflow measurements made in May 2008.

4-5. Maps showing:

4. Streamflow conditions at U.S. Geological Survey streamgages across the United States on November 30, 2007

5. Observed precipitation across the United States for the previous 24 hours at 7:00 a.m. Central Standard Time on January 8, 2008

6. Graphs showing cumulative precipitation totals from June 1,2007 , to July 31,2008 , in relation to historic average cumulative precipitation for selected sites in the Midwest.

7-14. Maps showing:

7. Cumulative precipitation totals for January $7-9,2008$, and locations of U.S. Geological Survey streamgages in Illinois, Indiana, and Michigan with peak streamflows that had an annual exceedance probability less than 10 percent ...vi

1

. .1

4

6

6

USGS hydrographer inspecting the gage house on the Current River near Doniphan, Missouri (USGS streamgage 07068000). Photograph by Paul Rydlund, USGS. 


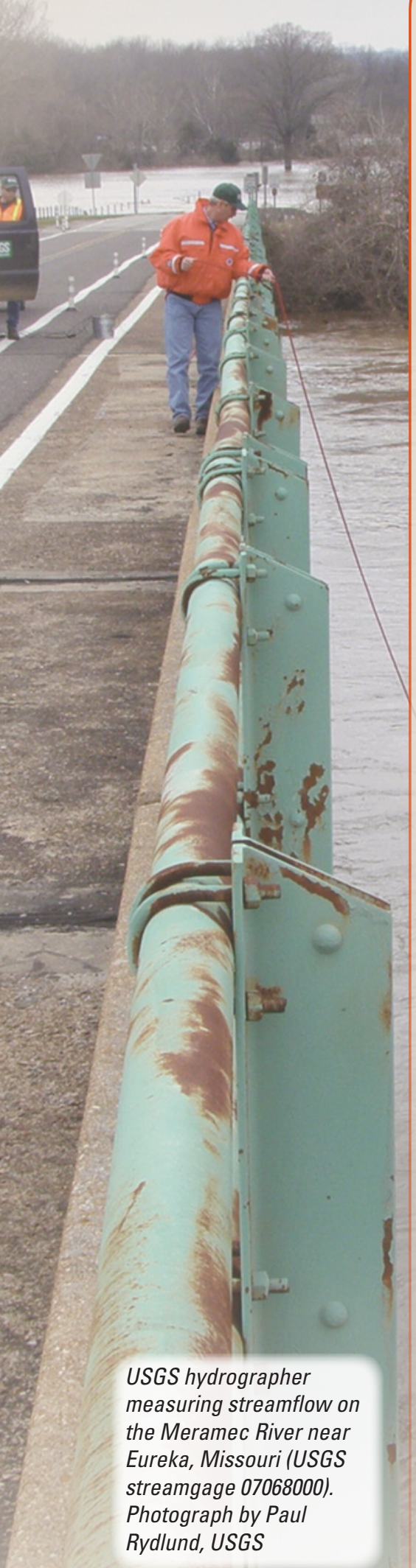

8. Cumulative precipitation totals for February 3-7, 2008, and locations of U.S. Geological Survey streamgages in Illinois and Indiana with peak streamflows that had an annual exceedance probability less than 10 percent

9. Streamflow conditions at U.S. Geological Survey streamgages on February 28, 2008 (U.S. Geological Survey, 2007)

10. Cumulative precipitation totals for March 16-20, 2008, and locations of U.S. Geological Survey streamgages in Arkansas, Illinois, Indiana, Missouri, and Oklahoma with peak streamflows that had an annual exceedance probability less than 10 percent.

11. Cumulative precipitation totals for $A$, April 7-11, 2008, and locations of U.S. Geological Survey streamgages in Arkansas, Missouri, and Oklahoma with peak streamflows that had an annual exceedance probability less than 10 percent; and $B$, cumulative precipitation totals for April 21-25, 2008, and locations of U.S. Geological Survey streamgages in lowa with peak streamflows that had an annual exceedance probability less than 10 percent.

12. Cumulative precipitation totals for May 21 through June 14, 2008, and locations of U.S. Geological Survey streamgages in several Midwestern States with peak streamflows that had an annual exceedance probability less than 10 percent.

13. Annual exceedance probability for the rainfall total from May 23, 2008, to June 12, 2008

14. Streamflow for Wabash River at Riverton, Indiana and White River at Petersburg, Indiana

15-16. Maps showing:

15. Cumulative precipitation totals for $A$, July $5-8,2008$, and locations of U.S. Geological Survey streamgages in lowa with peak streamflows that had an annual exceedance probability less than 10 percent; and $B$, cumulative precipitation totals for July $17-28,2008$, and locations of U.S. Geological Survey streamgages in lowa and Missouri with peak streamflows that had an annual exceedance probability less than 10 percent.

16. Cumulative precipitation totals for $A$, September $1-5,2008$, the path of the remnants of Hurricane Gustav, and locations of U.S. Geological Survey streamgages in Arkansas with peak streamflow that had an annual exceedance probability less than 10 percent; and $B$, cumulative precipitation totals for September 11-15, 2008, the path of the remnants of Hurricane Ike, and locations of U.S. Geological Survey streamgages in Illinois, Indiana, lowa, Kansas, Michigan, Missouri, and Oklahoma with peak streamflows that had an annual exceedance probability less than 10 percent

17. Map and graphs showing annual peak streamflows for the period of record up to 2008 and the 1-percent annual exceedance probability at selected U.S. Geological Survey streamgages in the Midwest

18-20. Graphs showing:

18. Streamflow for selected U.S. Geological Survey streamgages for the 2008 flood period and previous major floods, and the 10-percent annual exceedance probability for each site 
19. Effects of annual peak streamflows on moving 50-percent, 2-percent, and 1-percent unweighted annual exceedance probability flood quantiles through time at selected U.S. Geological Survey streamgages.

20. Increase in the 0.2-percent, 1-percent, and 50-percent unweighted annual exceedence probability flood quantiles for unregulated streams in the Midwest with more than 10 years of record when 2008 peak streamflow data were included in the flood-probability analysis.

21-22. Maps showing:

21. Percentage changes in the median annual peak streamflow values for selected U.S. Geological Survey streamgages on unregulated streams with data from 1958 to 2007

22. Percentage changes in the median annual peak streamflow values for selected U.S. Geological Survey streamgages on unregulated streams with data from 1918 to 2007

\section{Tables}

1-7. Summary of peak stages, streamflows, and flood-probability estimates for selected U.S. Geological Survey streamgages during:

1. January 2008.

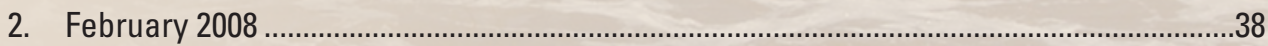

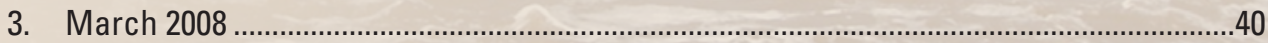

4. April 2008

5. May and June 2008

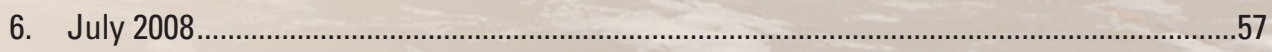

7. September 2008

\section{Conversion Factors}

Inch/Pound to SI

\begin{tabular}{|c|c|c|}
\hline Multiply & By & To obtain \\
\hline & Length & $35 x^{2}=$ \\
\hline foot $(\mathrm{ft})$ & 0.3048 & $\operatorname{meter}(\mathrm{m})$ \\
\hline \multirow[t]{2}{*}{ mile (mi) } & 1.609 & kilometer $(\mathrm{km})$ \\
\hline & Area & $3 x^{2}-2$ \\
\hline square mile $\left(\mathrm{mi}^{2}\right)$ & 259.0 & hectare (ha) \\
\hline \multirow[t]{3}{*}{ square mile $\left(\mathrm{mi}^{2}\right)$} & 2.590 & square kilometer $\left(\mathrm{km}^{2}\right)$ \\
\hline & Volume & 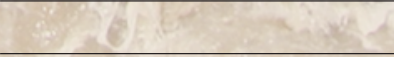 \\
\hline & Flow rate & \\
\hline foot per second (ft/s) & 0.3048 & meter per second $(\mathrm{m} / \mathrm{s})$ \\
\hline cubic foot per second $\left(\mathrm{ft}^{3} / \mathrm{s}\right)$ & 0.02832 & cubic meter per second $\left(\mathrm{m}^{3} / \mathrm{s}\right)$ \\
\hline
\end{tabular}




\section{Glossary}

Note: Glossary definitions are taken from Langbein and Iseri (1960) whenever possible

Annual exceedance probability (AEP) The probability, or chance, of a flood of a given streamflow magnitude being equaled or exceeded in any given year. The probability can be expressed as a fraction, decimal, or percentage.

\section{Annual exceedance probability flood} quantile (AEP flood quantile) The value of the peak streamflow that corresponds to a particular annual exceedance probability (for example, 1-percent AEP flood quantile)

Bulletin 17B Report by the Interagency Advisory Committee on Water Data, published in 1982, that delineates the recommended method for flood-probability analysis in the United States.

Confidence Limits To gauge the accuracy of an approximation based on a probability distribution, upper and lower confidence limits can be estimated based on the properties of the probability distribution. This report includes the 95-percent confidence limits of the estimate of the flood quantiles as computed by the methods outlined in Bulletin $17 \mathrm{~B}$.

Discharge In its simplest concept discharge means outflow; therefore, the use of this term is not restricted as to course or location, and it can be applied to describe the flow of water from a pipe or from a drainage basin.

Flood An overflow or inundation that comes from a river or other body of water, and causes or threatens damage.

Flood Peak The highest value of the stage or streamflow attained by a flood; often designated as peak stage or peak streamflow respectively.

Flood Quantile See "Annual Exceedance Probability Flood Quantile"

Flood Stage The stage at which overflow of the natural banks of a stream begins to cause damage in the reach in which the water surface elevation is measured.

Hydrograph A graph showing stage, streamflow, velocity, or other property of water with respect to time.

Log-Pearson Type III Probability Distribution (LPIII) One of the family of probability distributions developed by Karl Pearson that is used in the United States as a bestfit for the distribution of annual peak flood streamflows in the Bulletin 17B analysis procedures developed by the Interagency Advisory Committee on Water Data (1982).

Peak-of-Record Streamflow The largest instantaneous streamflow value for the period that data have been collected.

Peak Stage See "Flood Peak."

Peak Streamflow See "Flood Peak."

Precipitation As used in hydrology, precipitation is the discharge of water, in liquid or solid state, out of the atmosphere, generally upon a land or water surface. It is the common process by which atmospheric water becomes surface or subsurface water. The term "precipitation" is also commonly used to designate the quantity of water that is precipitated.

Probability A means to express the likelihood of something occurring, also known as chance. The probability can be expressed as a fraction, decimal, or percentage.

Probability Distribution Describes the range of possible values that a random variable can attain and the probability that the value of the random variable is within any subset of that range.

Rating Curve A graph showing the relation between the stage (gage height), usually plotted as the ordinate, and amount of water flowing in the channel (streamflow) expressed as volume per unit time, plotted as abscissa. 
Recurrence Interval The average interval of time within which the given flood is expected to be equaled or exceeded once.

Regional Regression Equation Equation developed through use of regression techniques that relate the flood-probability data at many streamgages in a region to the basin characteristics of the streams monitored by the streamgages. For any location along a stream, a user can enter the basin characteristics (drainage area, basin slope, etc.) as independent variables into the equations and compute various flow characteristics (for example, 1-percent AEP flood quantile, 2-percent AEP flood quantile, and annual mean streamflow).

Stage Height of a water surface above an established datum, also known as gage height.

Streamflow The discharge that occurs in a natural channel. Although the term discharge can be applied to flow in a canal, the word streamflow uniquely describes the discharge in a surface stream course. The units of measurement often are reported in cubic feet per second $\left(\mathrm{ft}^{3} / \mathrm{s}\right)$.

Streamgage A particular site on a stream where a record of streamflow is obtained.

Trend The change of a particular variable with either time or spatial location as computed by statistical analysis.

Trend Magnitude The value of the trend as computed by a statistical analysis.

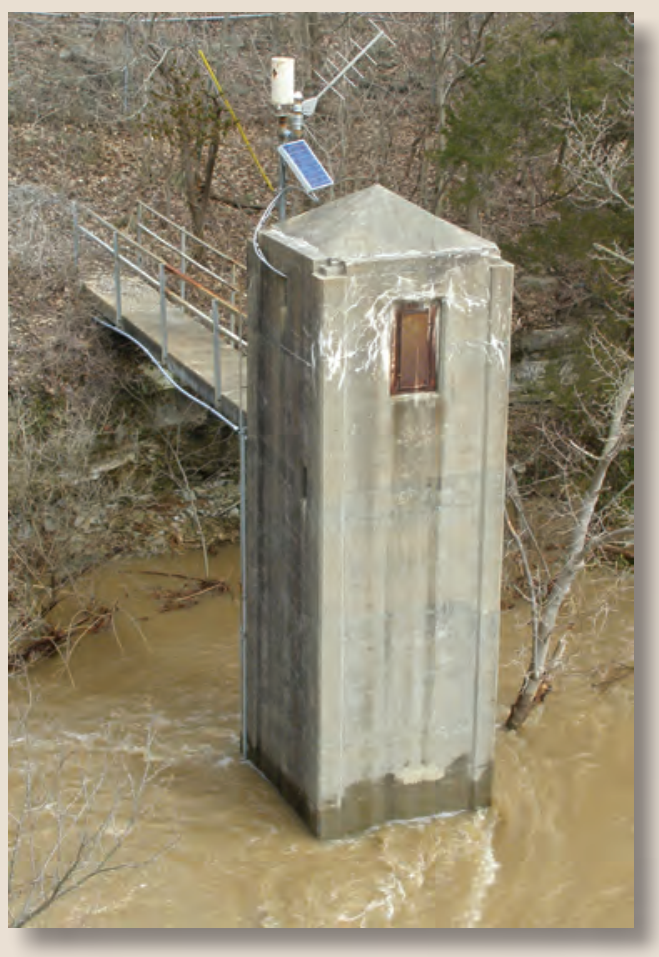

USGS streamgage on the Meramec River near Eureka, Missouri (USGS streamgage 07019000). Photograph by Robert Holmes, USGS. 


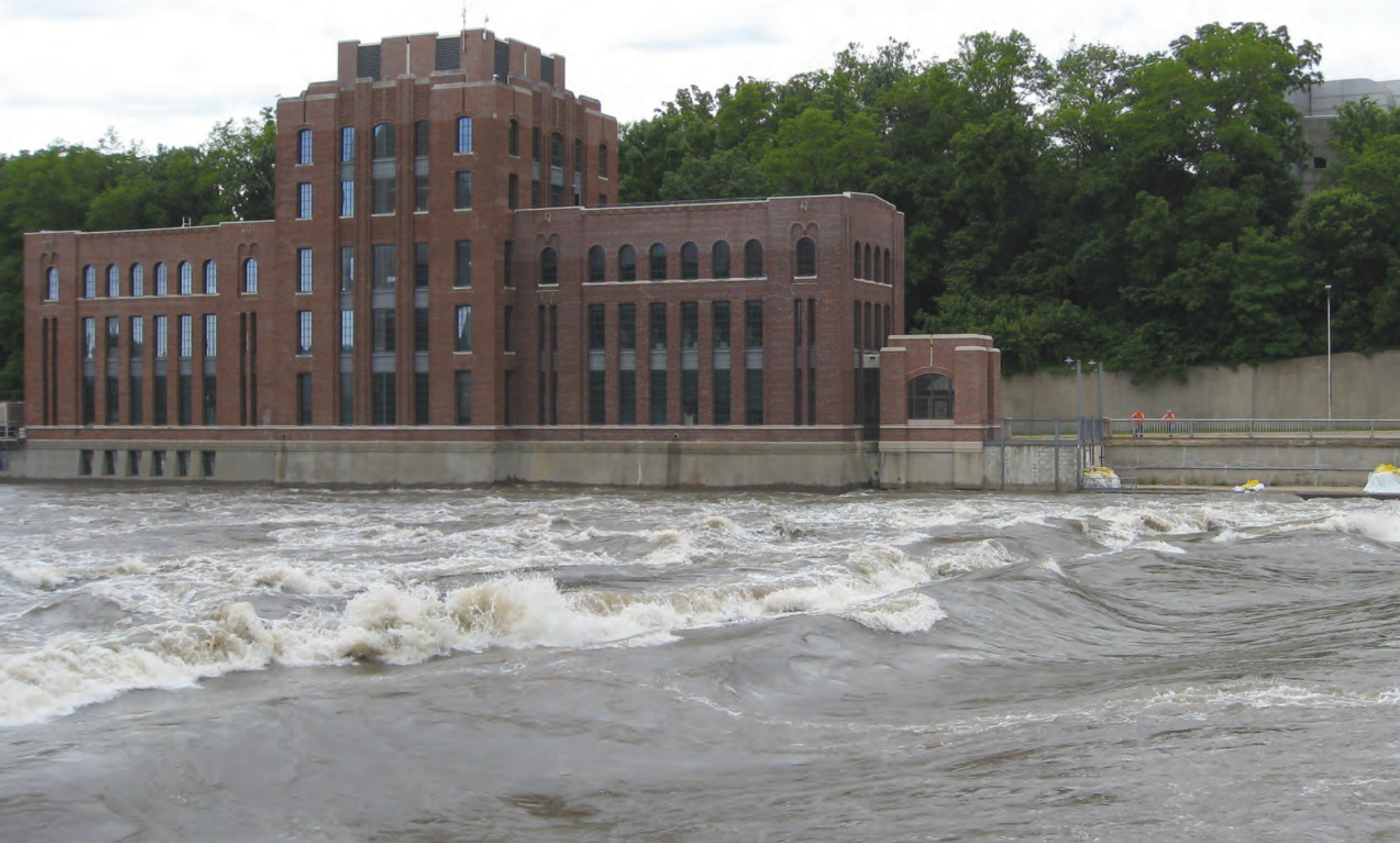

Flooding at Burlington Street Bridge over the lowa River at lowa City, lowa, July 2008. Photograph by James Caldwell, USGS. 


\title{
Flooding in the United States Midwest, 2008
}

\author{
By Robert R. Holmes, Jr., Todd A. Koenig, and Krista A. Karstensen
}

\section{Abstract}

During 2008, record precipitation amounts, coupled with already saturated soils, resulted in flooding along many rivers in the United States Midwest. Separate flooding events occurred in January, February, March, April, May, June, July, and September of 2008. The June floods were by far the most severe and widespread with substantial (and in places record) flooding and damage occurring in Illinois, Indiana, Iowa, Kansas, Michigan, Minnesota, Missouri, Nebraska, Oklahoma, South Dakota, and Wisconsin. Indiana had the most recurrent flooding during 2008, with peak-of-record streamflows occurring during January, February, March, June, and September. During 2008, peak-of-record streamflows were recorded at more than 147 U.S. Geological Survey (USGS) streamgages. The annual exceedance probability of the peak streamflows at 26 streamgages was less than 0.2 percent and between 0.2 and 1 percent at 67 streamgages. Trends in flood magnitudes were computed for USGS Midwest streamgages that had no regulation. No Midwest-wide systematic trends upward or downward were evident, although clusters of consistent trends (both upward and downward) were detected in parts of the Midwest.

\section{Introduction}

Flooding occurred on numerous rivers throughout the Midwestern United States (hereafter referred to as the Midwest) at various times during 2008 (fig. 1). The Midwest, and in particular the southern Midwest, has been identified as an area of the conterminous United States where the largest flood streamflows are likely to occur because of the close proximity of subtropical moisture from the Gulf of Mexico (O'Connor and Costa, 2003). This tendency toward large floods was dramatically displayed in 2008 as flooding dominated the media for weeks, with reports of property destruction, evacuations, and loss of life. At various times during 2008, flooding in the Midwest occurred in parts of Arkansas, Illinois, Indiana, Iowa, Kansas, Michigan, Minnesota, Missouri, Nebraska, Oklahoma, South Dakota, and Wisconsin. Examples of the severity of the flooding include the Cedar River, which inundated 14 percent of Cedar Rapids, Iowa, displaced more than 24,000 people, and damaged or destroyed an estimated 5,400 houses and 700 businesses (National Weather Service, 2009). In southwestern Wisconsin, an earthen embankment between Lake Delton and the Wisconsin
USGS hydrographer making a streamflow measurement on the Salt Fork near Sidney, Illinois (USGS streamgage 03337848). Photograph by Robert Holmes, USGS. 


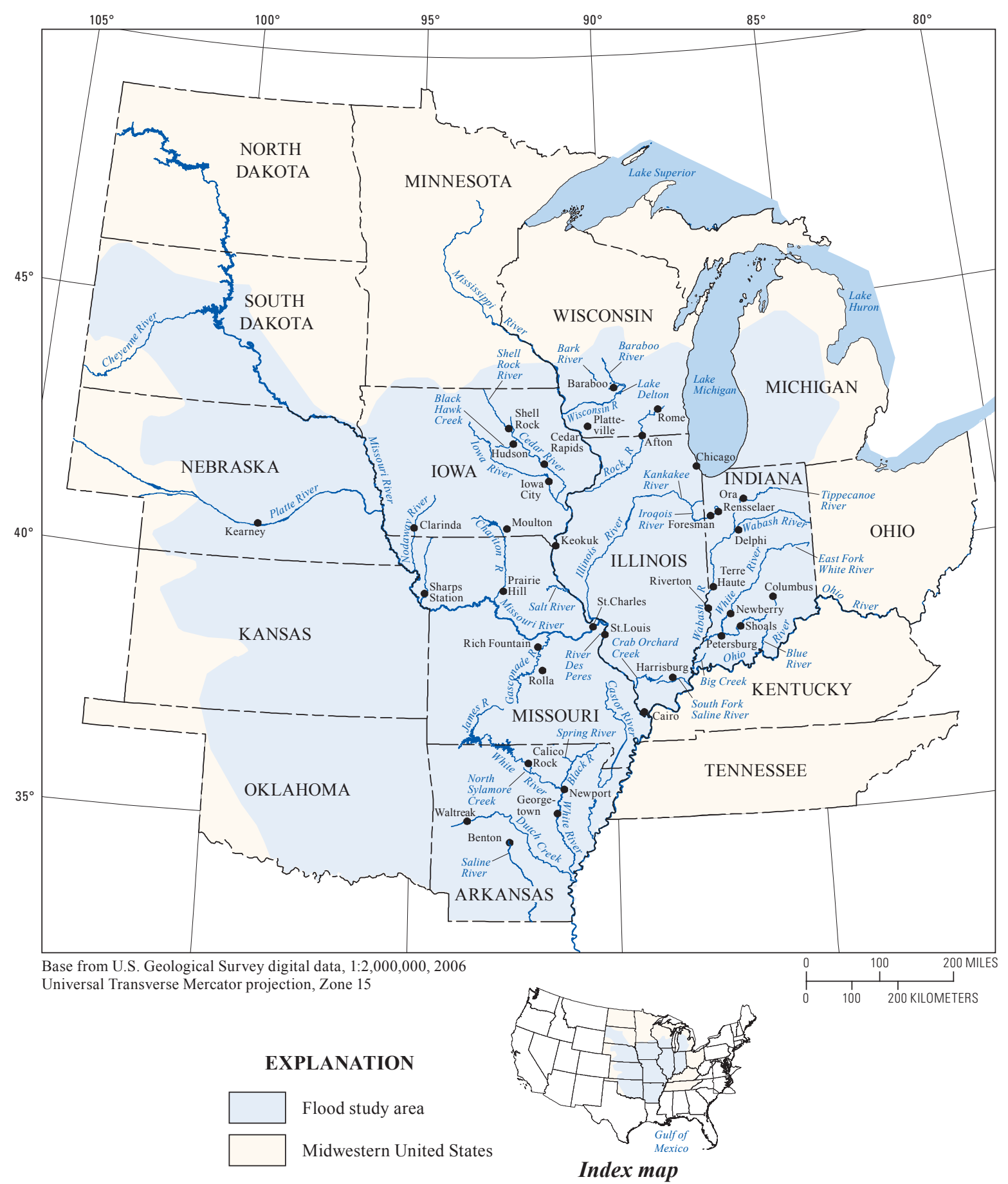

Figure 1. The United States Midwest and general areas of flooding streams, January to September, 2008. 


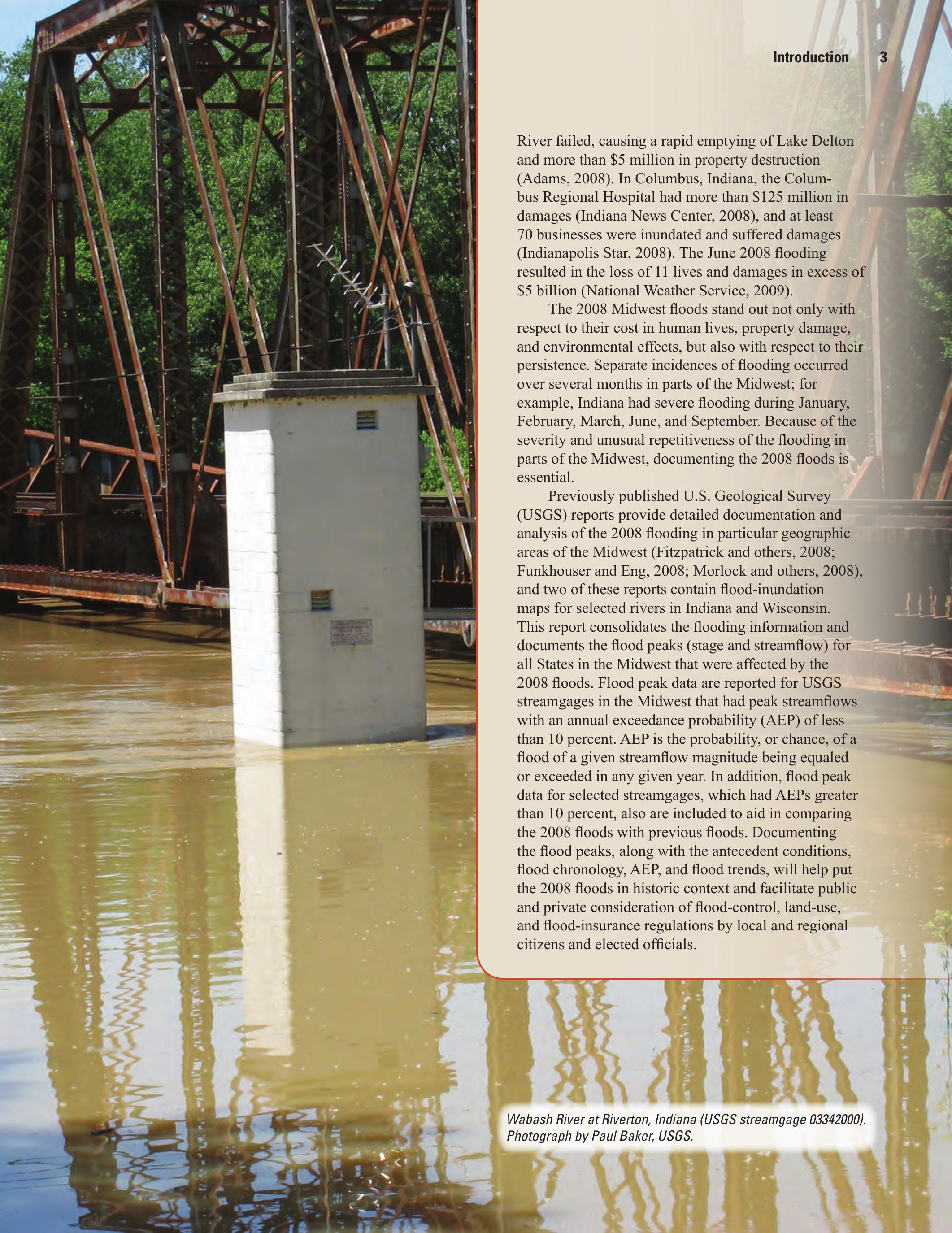




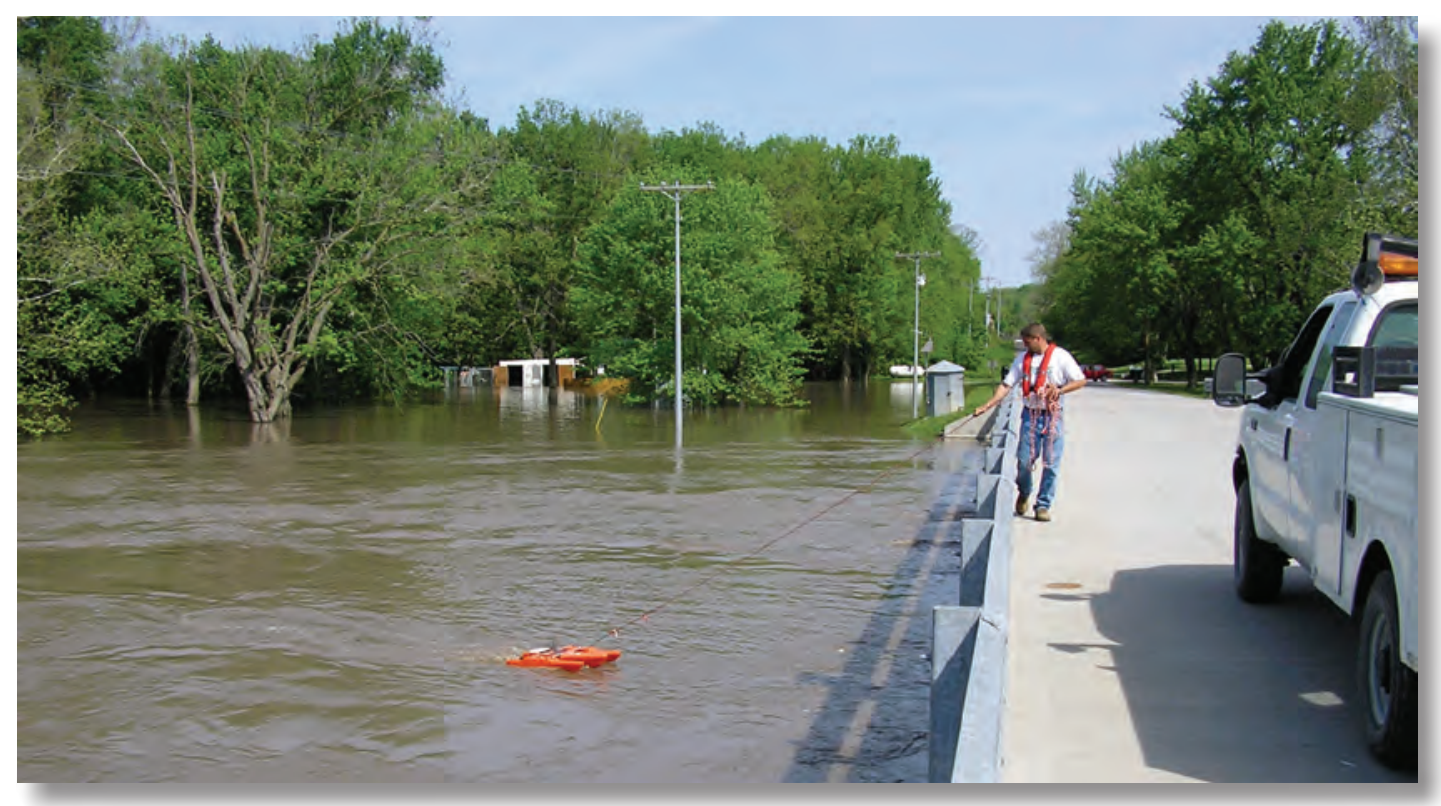

Figure 2. U.S. Geological Survey hydrographer measuring streamflow on the Platte River near Sharps Station, Missouri (USGS streamgage 06821190), with an acoustic Doppler current profiler (ADCP) mounted to a tethered boat to collect velocity and depth readings that are sent by radio link to a laptop computer inside the field vehicle. The gage house for this site can be seen in the background. Photograph by Chris Rowden, USGS.

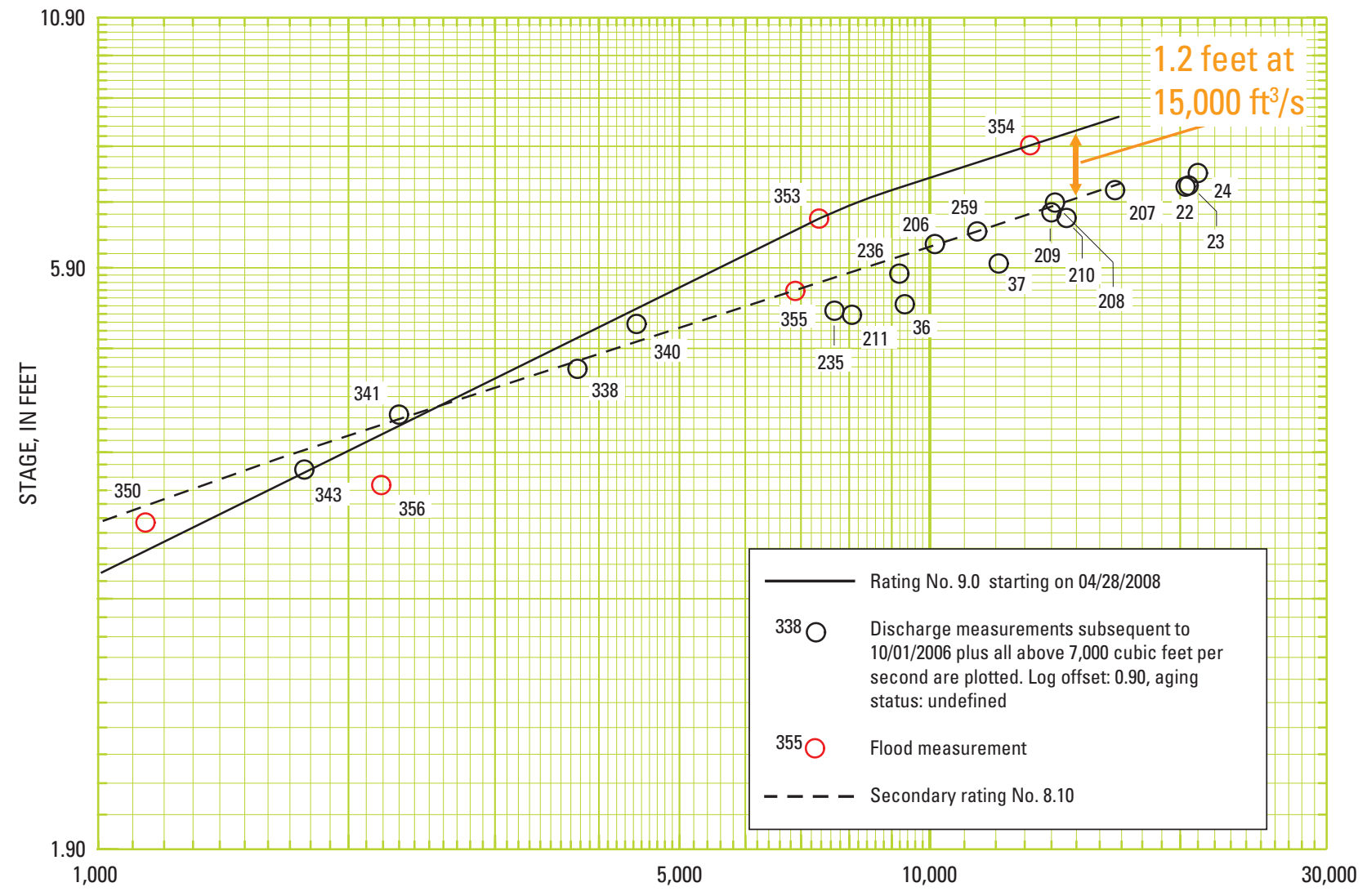

DISCHARGE, IN CUBIC FEET PER SECOND $\left(\mathrm{ft}^{3} / \mathrm{s}\right)$

Figure 3. Changes in the rating curve for the Platte River near Kearney, Nebraska (USGS streamgage 06770200), as a result of on-site direct streamflow measurements made in May 2008. 


\section{Flooding: Causes, Chronology, and Magnitude}

An understanding of the causes of flooding requires some knowledge of hydrology and the hydrologic cycle. The hydrologic cycle is described by Hjelmfelt and Cassidy (1975) as follows:

"Water occurs in many places and in many phases on, in, and over the earth. The transformation from one phase to another and the motion from one location to another constitutes the hydrologic cycle, which is a closed system having no beginning nor end."

The hydrology of a region as large as the Midwest is complex because of the heterogeneity of the variables controlling the movement of water in the hydrologic cycle: precipitation (source, type, rate, and amount), vegetation, temperature, soil, geology, topography, stream gradient, and man-made structures. In addition, the flood hydrology of small basins is different than that of large basins, with different characteristic causes of flooding. Flooding in small basins often is caused by localized intense precipitation of short duration (minutes to hours). Flooding in large basins often is caused by large amounts of sustained precipitation over a long duration (days to weeks) and broad geographic area.

The 2008 flooding in the Midwest occurred on small and large streams. The area of flooding was widespread and, at various times, included parts of Arkansas, Illinois, Indiana, Iowa, Kansas, Michigan, Minnesota, Missouri, Nebraska,

Oklahoma, South Dakota, and Wisconsin. Separate flooding events occurred in January, February, March, April, May, June, July, and September of 2008.

\section{Antecedent Conditions for the $\mathbf{2 0 0 8}$ Midwest Flooding}

The genesis of most major widespread flooding is not one particular storm or precipitation event. Most flooding is the result of frequent and consistently abundant precipitation occurring over the same geographic area for an extended period. As the soil becomes increasingly saturated and the receiving streams reach bankfull stage, additional precipitation results in flooding. Much of the area in the Midwest that was affected by flooding in 2008 began in the early winter of 2007 with streamflows in the normal to above-normal ranges (fig. 4). Above-average snowfalls occurred in the northern one-half of the Midwest during the winter of 2007-2008, and the snow accumulated into large snowpacks. In some parts of central Wisconsin, the snowpacks contained the equivalent of 10 to 12 inches (in.) of water (National Weather Service, 2009). Although the melting of the snowpacks was not a direct cause of catastrophic flooding, the melting contributed to the flooding by saturating the soils and filling the streams to near bankfull conditions in numerous locations.

The first flood-inducing precipitation event began on January 7, 2008 (fig. 5). This was the first of many rainfall events that occurred during the next several months across areas of the Midwest, and this event caused major flooding in parts of east-central Illinois and northern, western, and southwestern Indiana. Although this event did not result in severe 


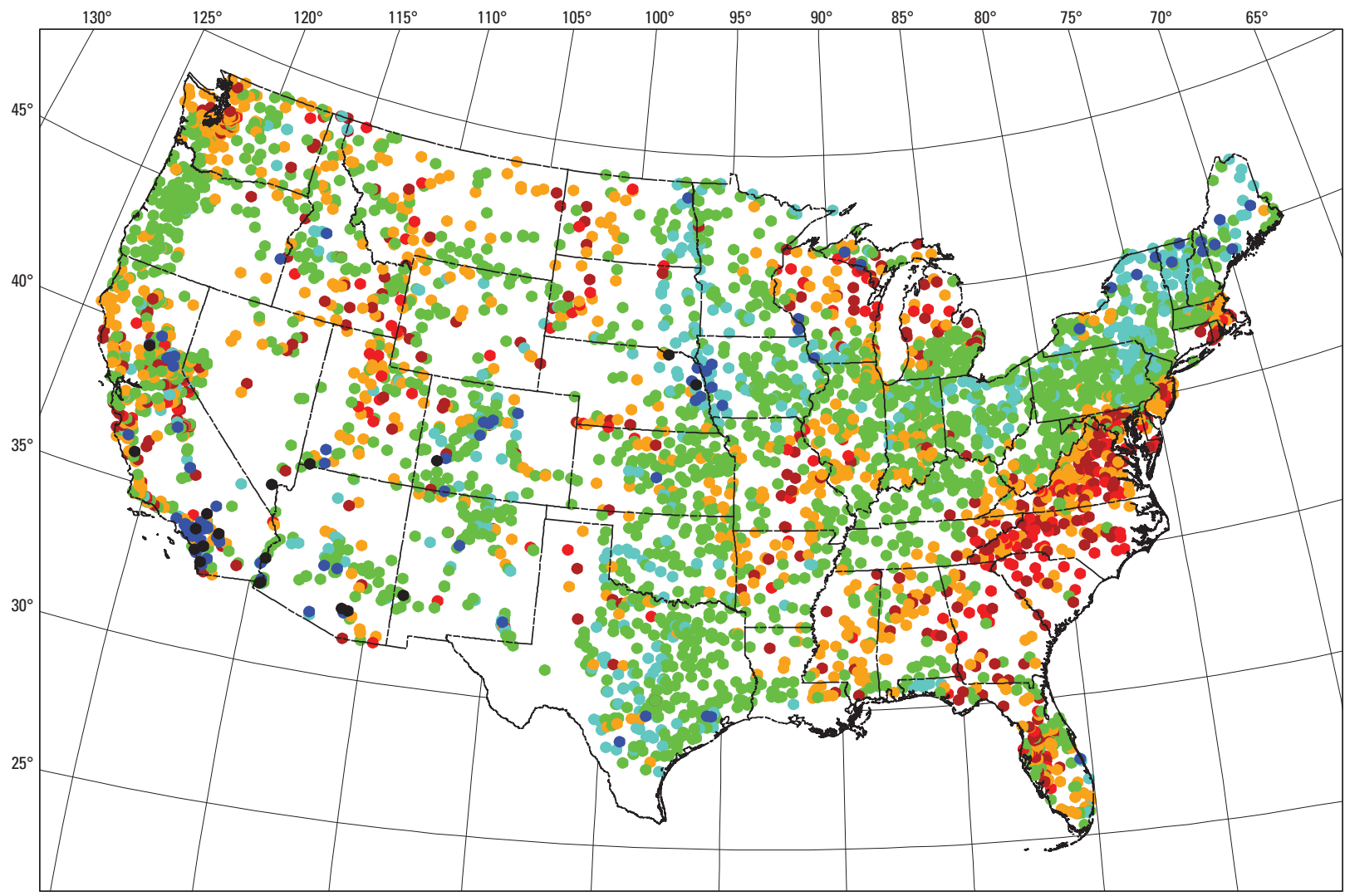

Base from U.S. Geological Survey digital data, 1:2,000,000, 2006

From U.S. Geological Survey WaterWatch, accessed Universal Transverse Mercator projection, zone 15

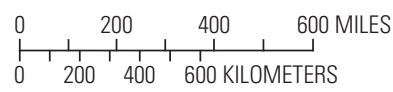

\section{EXPLANATION}

Streamflow conditions, in percentile classes
- High
- $10-24$, below normal
- Greater than 90 , much
- Less than 10 , much above normal below normal
- 76 - 90, above normal
- Low
- $25-75$, normal

Figure 4. Streamflow conditions at U.S. Geological Survey streamgages across the United States on November 30, 2007 (U.S. Geological Survey, 2007). 


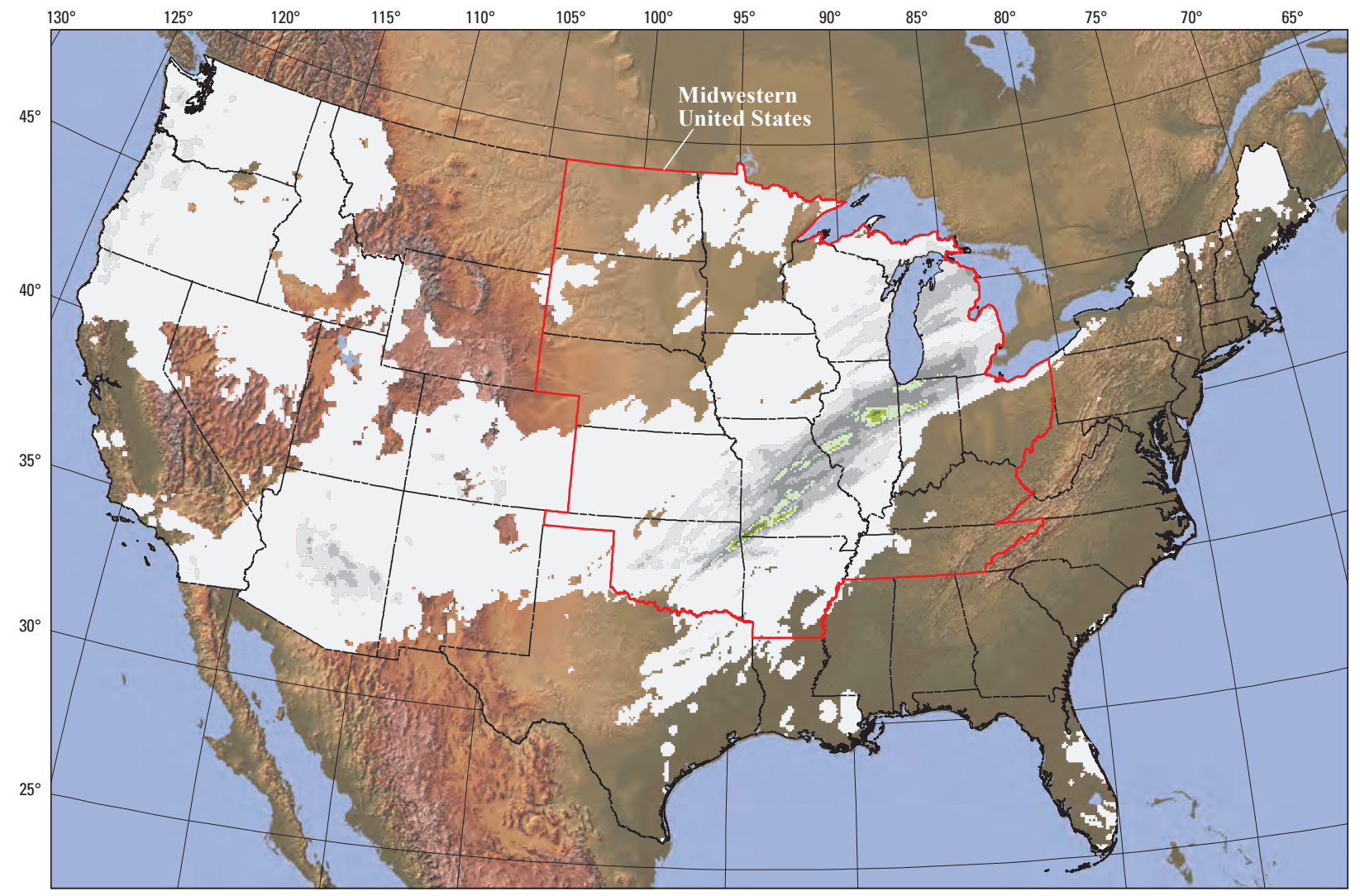

Base from U.S. Geological Survey digital data, 1:2,000,000, 2006 Universal Transverse Mercator projection, zone 15

From Advanced Hydrologic Prediction Service, National Weather Service, accessed February 1, 2009 (http://water.weather.gov)

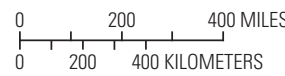

\section{EXPLANATION}

\section{Precipitation, in inches}

\begin{tabular}{|l|l|}
\hline $0-0.5$ & $3.0-4.0$ \\
\hline $0.5-1.0$ & $4.0-5.0$ \\
\hline $1.0-2.0$ & $5.0-6.0$ \\
\hline $2.0-3.0$ & $6.0-8.0$ \\
\hline
\end{tabular}

Figure 5. Observed precipitation across the United States for the previous 24 hours at 7:00 a.m. Central Standard Time on January 8, 2008. (National Weather Service, 2008a). 
A. Cedar Rapids, lowa

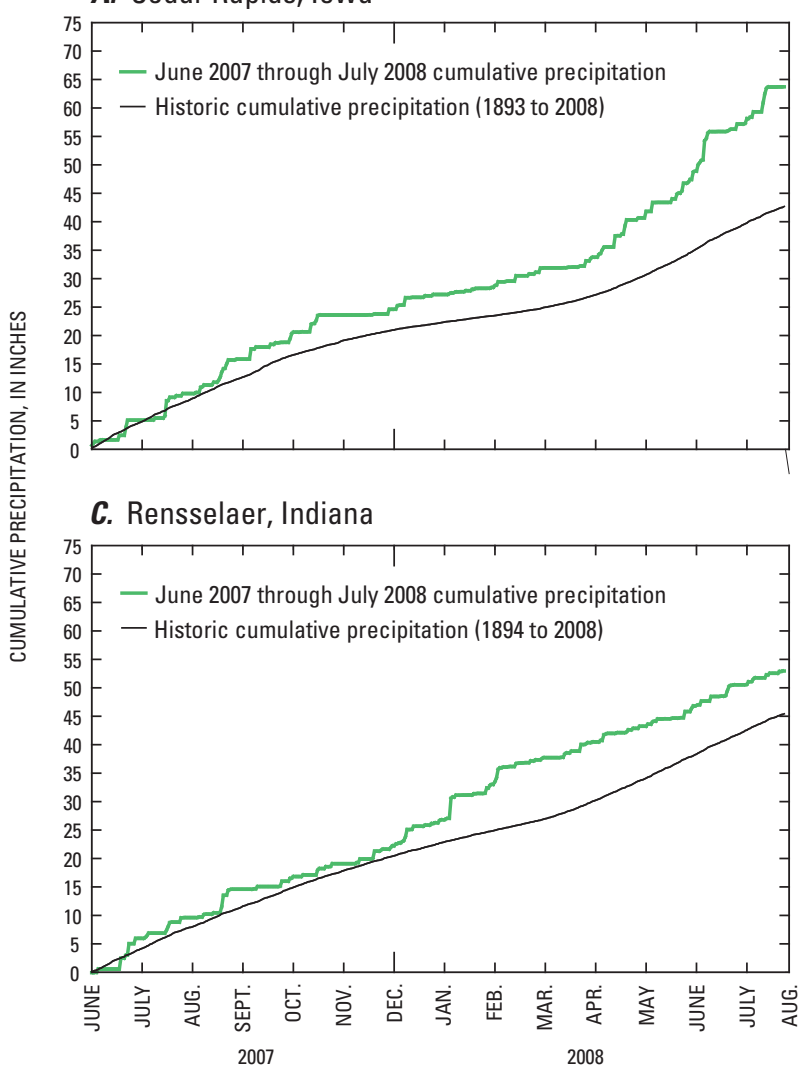

B. Platteville, Wisconsin

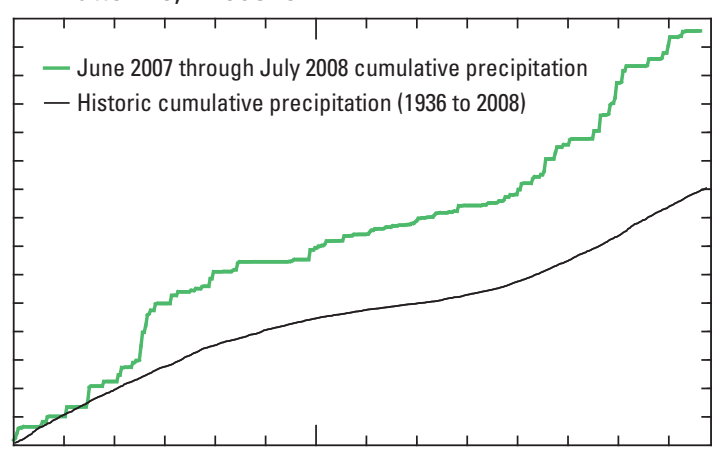

D. Rolla, Missouri

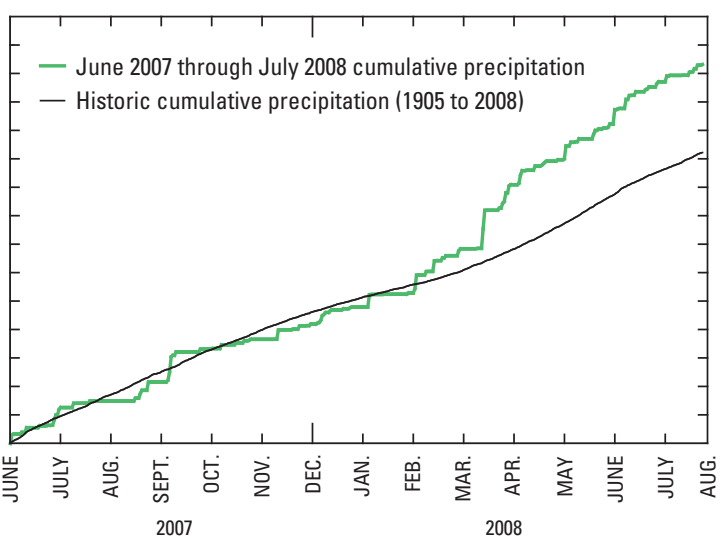

Figure 6. Cumulative precipitation totals from June 1, 2007, to July 31, 2008, in relation to historic average cumulative precipitation for selected sites in the Midwest. (National Climatic Data Center, 2008).

flooding outside of Indiana, the widespread rainfall contributed to increased soil-moisture levels and streamflows in other areas of the Midwest. Consistent above-normal precipitation during 2007-2008 occurred in much of the Midwest, as evidenced when comparing the June 2007 to July 2008 cumulative precipitation with historic average cumulative precipitation for four selected precipitation gages in the Midwest (figs. 6A-D).

\section{Chronology and Magnitude of Flooding: January through September 2008}

The 2008 Midwest floods were caused by persistent and excessive precipitation amounts on saturated soils. Record 6-month precipitation totals were set at 106 Midwest locations during January through June 2008 (Midwest Regional Climate Center, 2008). The 6-month total precipitation was composed of numerous discrete storm sequences that induced multiple flooding events in different geographic locations. Peak-of-record streamflows were set at 147 USGS Midwestern streamgages during 2008. The USGS streamgages that had peak streamflows with an AEP of less than 10 percent are listed in tables 1-7 (at the back of this report), with each table representing a unique flooding period during 2008. Selected streamgages that reported peak streamflow with AEPs greater than 10 percent also appear in the tables for comparison with other record flood periods [for example, Mississippi River at St. Louis, Missouri, and Wabash River at Terre Haute, Indiana (table 5)]. Each USGS streamgage listed in these tables contains a map "site number" that allows cross reference from the table to the respective map figure for that flood period. To minimize figure clutter, only the major rivers (for example, Illinois, Mississippi, Missouri, Ohio, and Wabash Rivers) and selected small rivers mentioned in the report text for that particular flood period are shown on the figures. The tables include 2008 peak-stage and streamflow data, previous peakof-record flood data, the estimated AEP for the 2008 peak streamflow, and estimates of the magnitude of the streamflow corresponding to the 4-percent, 2-percent, 1-percent, and 0.2-percent AEP. For each figure corresponding to a particular flood period, the size of the symbol for each streamgage represents the estimated AEP that corresponds to the magnitude of the observed peak streamflow - the less probable (less frequent) the peak streamflow, the larger the symbol.

The first major flooding occurred just after the new year began as the result of precipitation during January 7-9, 2008. Examination of daily NWS Next Generation Weather Radar (NEXRAD) observations indicated as much as 6.7 in. of precipitation occurred during these 3 days (fig. 7) on 


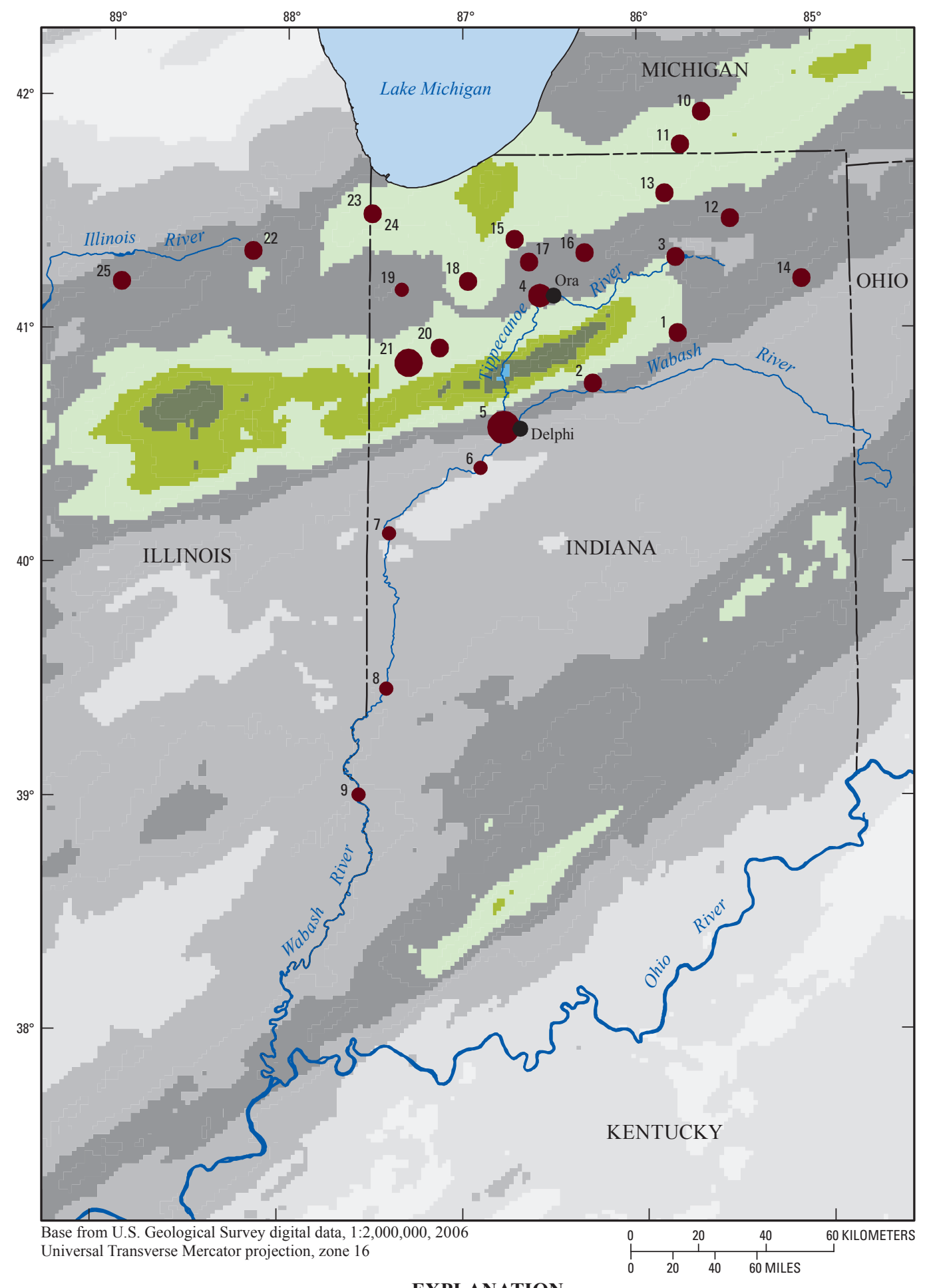

Precipitation, in inchesInterval $0.5,1$, and 2 inches

$\begin{array}{ll}0-0.5 & 3.0-4.0\end{array}$

$0.5-1.0 \quad 4.0-5.0$

$\begin{array}{ll}1.0-2.0 & 5.0-6.0\end{array}$

\begin{tabular}{l}
$2.0-3.0 \quad 6.0-8.0$ \\
\hline
\end{tabular}

EXPLANATION

Flood annual exceedance probability (AEP),

in percent-Number is site identifier (table 1).

Not all ranges are represented on map

- No data

- Greater than 10

$4.0-10$

$1.0-2.0$

$2.0-4.0$

$0.2-1.0$
Less than 0.2

Figure 7. Cumulative precipitation totals for January 7-9, 2008, and locations of U.S. Geological Survey streamgages in Illinois, Indiana, and Michigan with peak streamflows that had an annual exceedance probability less than 10 percent. 


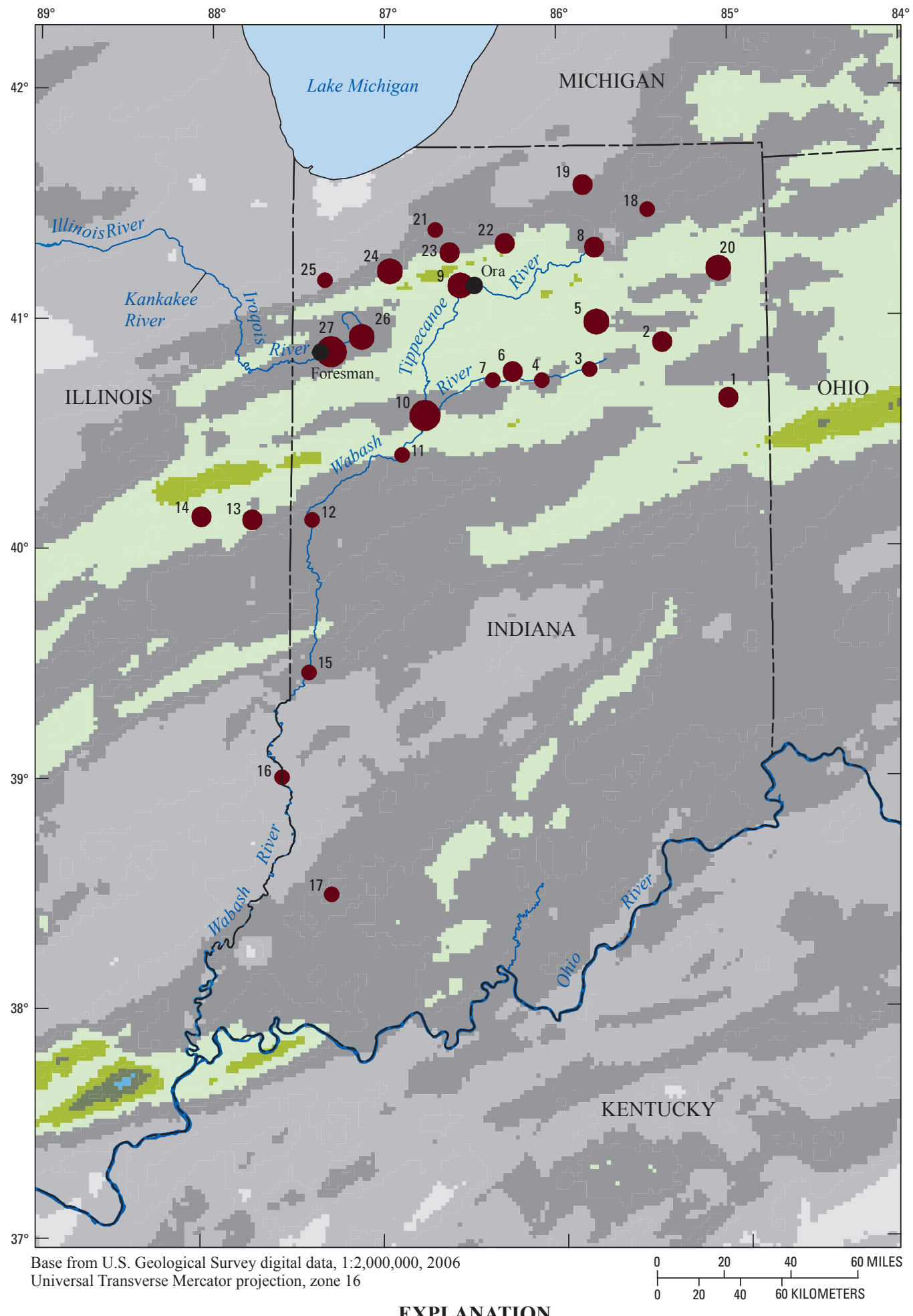

\section{EXPLANATION}

\begin{tabular}{|c|c|c|}
\hline \multicolumn{2}{|c|}{ Precipitation, in inches- } & $\begin{array}{l}\text { Flood annual exceedance probability } \\
\text { in percent-Number is site identifier }\end{array}$ \\
\hline $0-0.5$ & $3.0-4.0$ & Not all ranges are represented on map \\
\hline $0.5-1.0$ & $4.0-5.0$ & - No data \\
\hline $1.0-2.0$ & $5.0-6.0$ & Greater than 10 \\
\hline $2.0-3.0$ & $6.0-8.0$ & $\begin{array}{l}\text { Greater than } 10 \\
4.0-10\end{array}$ \\
\hline
\end{tabular}

Figure 8. Cumulative precipitation totals for February 3-7, 2008, and locations of U.S. Geological Survey streamgages in Illinois and Indiana with peak streamflows that had an annual exceedance probability less than 10 percent. 
frozen, often bare, ground, which resulted in major flooding in Illinois, Indiana, and Michigan. Peak-of-record streamflow occurred at USGS streamgages on the Tippecanoe River at Ora and Delphi, Indiana (USGS streamgages 03331500 and 03333050, respectively, table 1).

Precipitation that began on February 3, 2008, and continued through much of February 7 (fig. 8) resulted in an accumulation of up to $6.3 \mathrm{in}$. and flooding in Illinois and Indiana. The Iroquois River had a peak-of-record streamflow at the Foresman, Indiana, streamgage (USGS streamgage 05524500) that surpassed the 1958 record (table 2). The February flooding occurred in many of the same areas that had flooding during the previous month, with the Tippecanoe River being a prime example of recurrent flooding. The USGS streamgage near Ora, Indiana (USGS streamgage 03331500 ), had a peak streamflow of $9,200 \mathrm{ft}^{3} / \mathrm{s}$ on February 8 (table 2), which was within $90 \mathrm{ft}^{3} / \mathrm{s}$ of the January 10 peak streamflow of $9,290 \mathrm{ft}^{3} / \mathrm{s}$ (table 1). Although the severe flooding during February was limited to Illinois and Indiana, by the end of February 2008, the additional precipitation across the Midwest resulted in streamflows that were above normal at numerous USGS streamgages in Arkansas, Illinois, Indiana, Iowa, Kansas, Michigan, Minnesota, Missouri, Nebraska, Oklahoma, South Dakota, and Wisconsin (fig. 9).

Substantial rainfall that contributed amounts as much as 12.8 in. occurred during March 16-20, 2008, in a band through Arkansas, Illinois, Indiana, Missouri, and Oklahoma (fig. 10). Most of the rivers in the five-State flood area peaked by March 19, although some of the large basins peaked as late as March 24 (for example, White River near Georgetown,

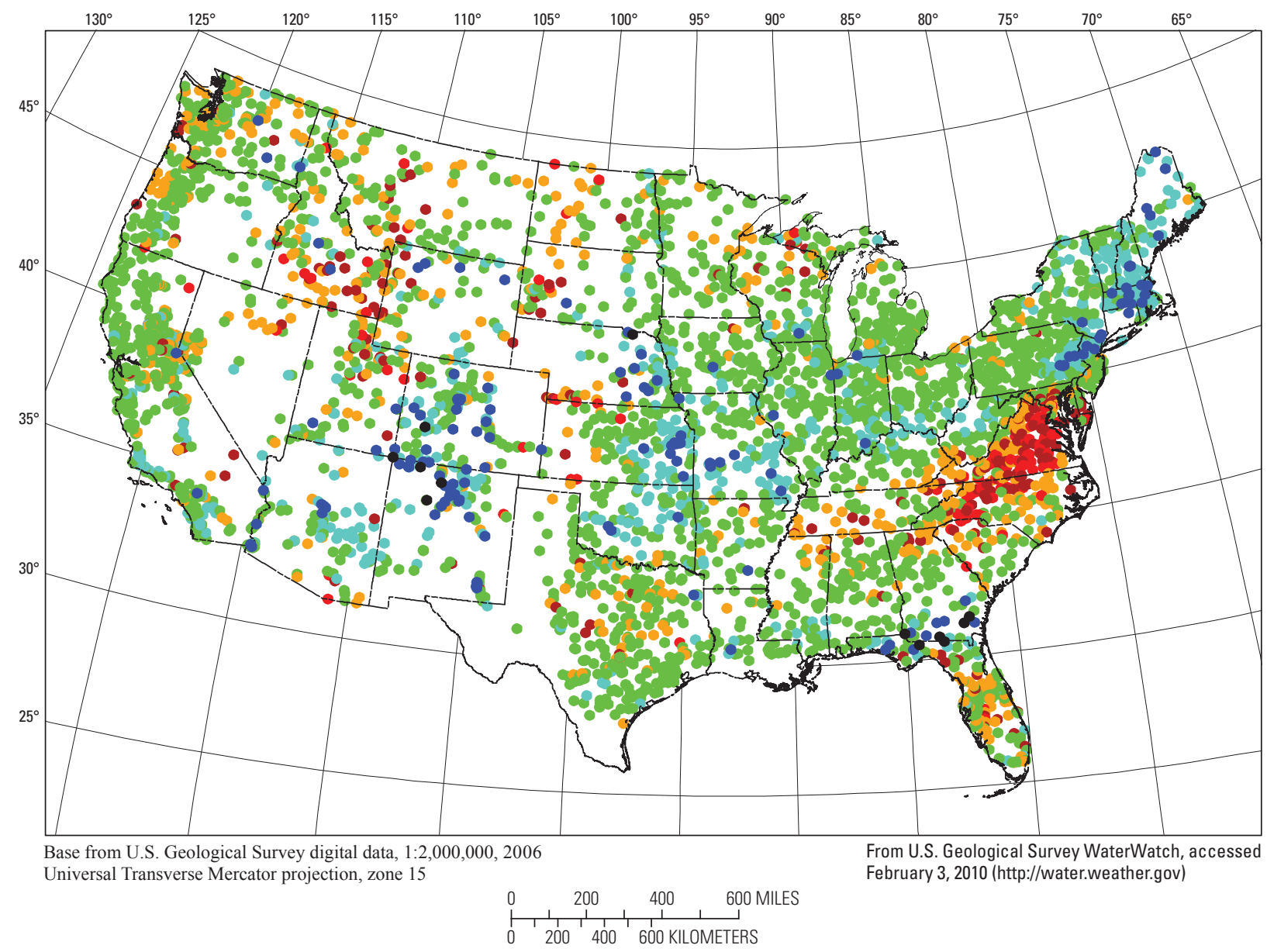

\section{EXPLANATION}

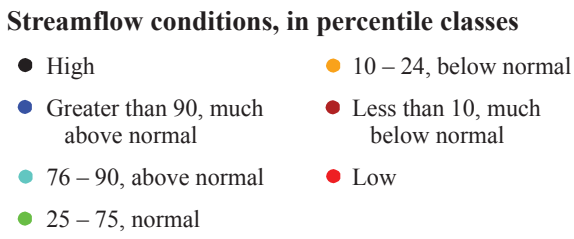

Figure 9. Streamflow conditions at U.S. Geological Survey streamgages on February 28, 2008 (U.S. Geological Survey, 2007). 
Arkansas (USGS streamgage 07076750), table 3). Peakof-record streamflows occurred on the Spring, White, and Black Rivers in Arkansas; the Castor and James Rivers in Missouri; the South Fork Saline River and Crab Orchard Creek in southern Illinois; and the Blue River and Big Creek in southern Indiana (table 3). Streamflow peaks on the Gasconade River in Missouri were near the flood of record (for example, Gasconade River near Rich Fountain, Missouri (USGS streamgage 06934000), table 3). The town of Harrisburg, Illinois, which is surrounded by a levee to protect it from backwater from the Ohio River approximately 30 miles (mi) away, was inundated by flooding from more than $11.5 \mathrm{in}$. of rain in less than 48 hours on March 18 and 19, 2008. Local drainage, interior to the levee system, proved to be too much for the pumping system and resulted in more than 44 businesses and 30 homes being flooded. The flooding resulted in an estimated \$16.8 million in damages (Fodor, 2009). In Arkansas, one remarkable scene of destruction was captured on video by USGS hydrologic technician Steven B. Franks, (U.S. Geological Survey, 2010) as he witnessed a house that had been washed into the White River floating downstream and colliding with a bridge at the White River at Calico Rock, Arkansas (USGS streamgage 07060500).

Additional flooding occurred in early April 2008 in many of the same areas of Arkansas, Missouri, and Oklahoma as in March. As much as 9.6 in. of rain fell during April 7-11, 2008,

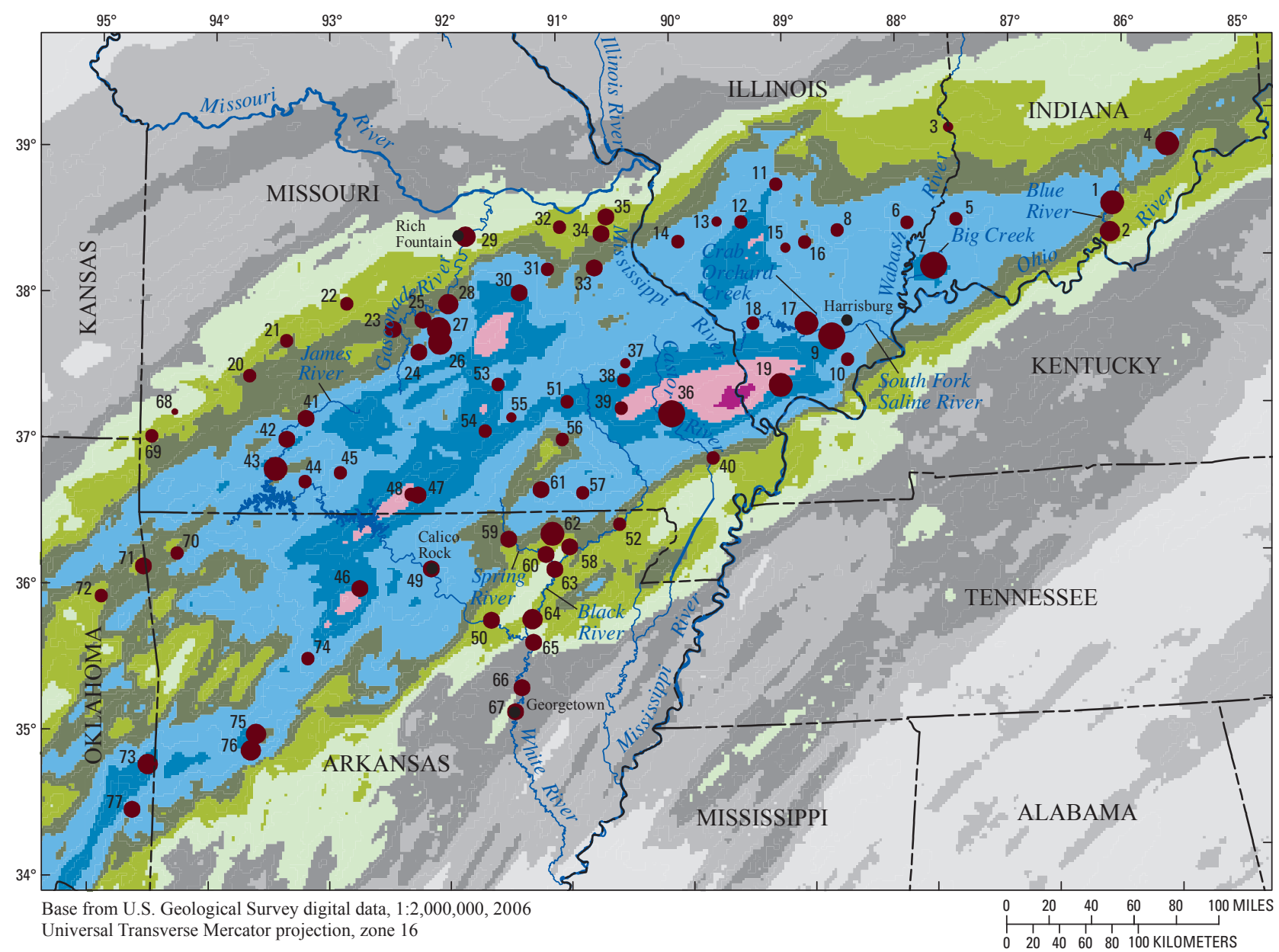

EXPLANATION

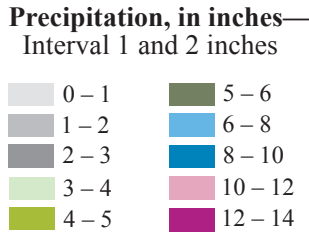

Flood annual exceedance probability (AEP), in percent-Number is site identifier (table 3 ). Not all ranges are represented on map

- No data

- Greater than 10

- $4.0-10$

- $2.0-4.0$

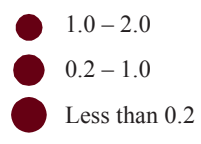

Less than 0.2

Figure 10. Cumulative precipitation totals for March 16-20, 2008, and locations of U.S. Geological Survey streamgages in Arkansas, Illinois, Indiana, Missouri, and Oklahoma with peak streamflows that had an annual exceedance probability less than 10 percent. 
which produced flooding along numerous rivers (fig. 11A) and peak-of-record streamflow on North Sylamore Creek in Arkansas that exceeded the 1982 record peak streamflow (USGS streamgage 07060710, table 4).

An isolated system in late April produced flooding from up to 6.3 in. of precipitation that fell in eastern Iowa during April 22-26, 2008 (fig. 11B). Substantial flooding was limited mostly to streams with drainage areas less than 400 square miles $\left(\mathrm{mi}^{2}\right)$, such as Black Hawk Creek at Hudson, Iowa (USGS streamgage 05463500), where a peak-of-record streamflow occurred on April 25, 2008 (table 4). Although the
late-April precipitation produced only isolated flooding on smaller drainages, it provided additional moisture for continued soil saturation in Iowa.

Substantial rainfalls occurred during May and June throughout much of the Midwest, resulting in some of the worst flooding during 2008. Examination of daily NEXRAD rainfall observations for the Midwest area that included Illinois, Indiana, Iowa, Michigan, Missouri, and Wisconsin indicated that from May 21 to June 14, 2008, precipitation amounts greater than $0.5 \mathrm{in}$. occurred daily somewhere within the six-State area (National Weather Service, 2008a). Total

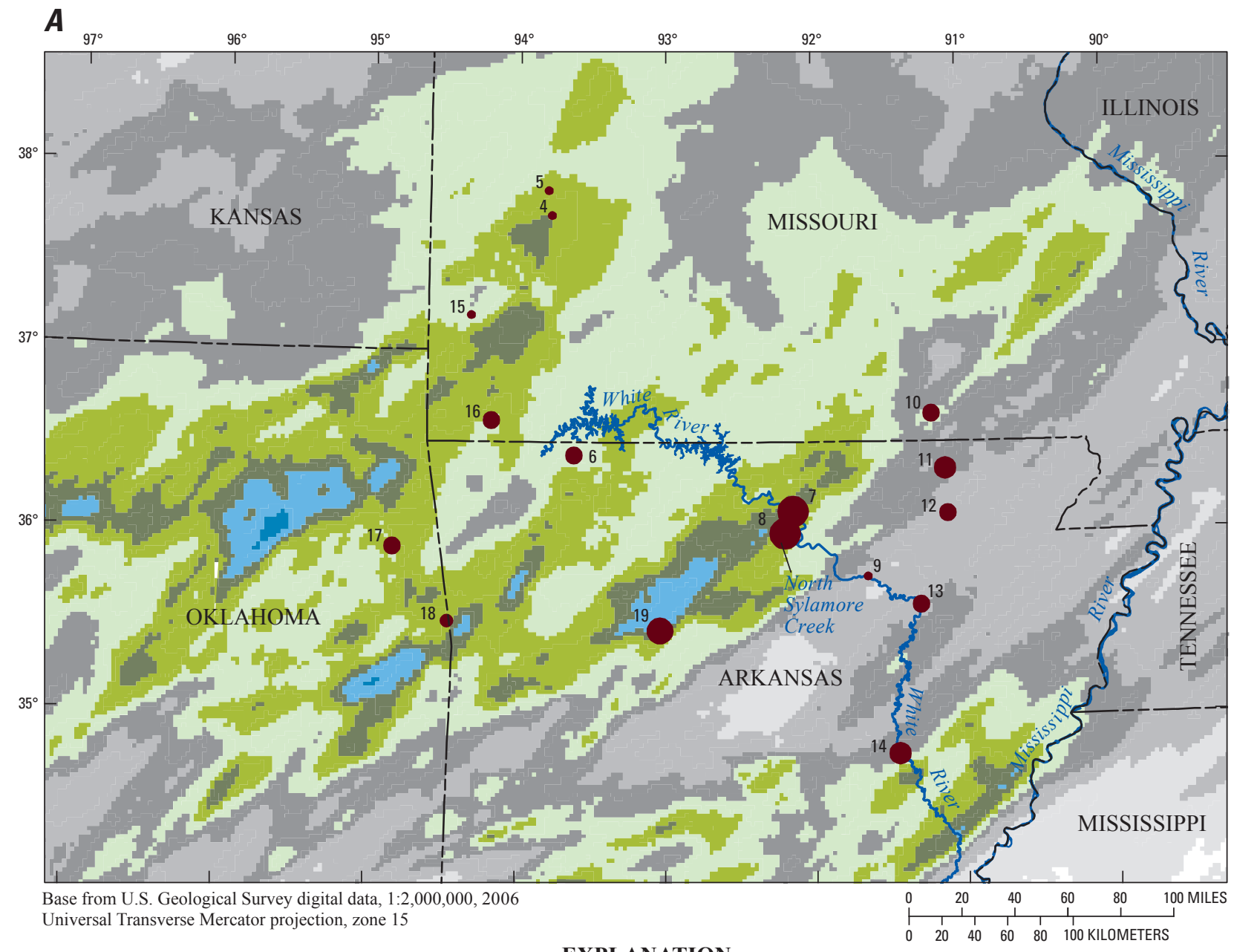

EXPLANATION

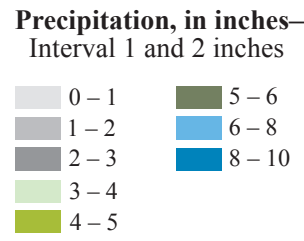

Flood annual exceedance probability (AEP),

in percent-Number is site identifier (table 4).

Not all ranges are represented on map

- No data

- Greater than 10

$4.0-10$

$2.0-4.0$

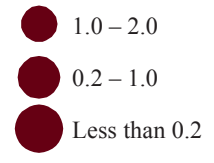

Figure 11. Cumulative precipitation totals for $A$, April 7-11, 2008, and locations of U.S. Geological Survey streamgages in Arkansas, Missouri, and Oklahoma with peak streamflows that had an annual exceedance probability less than 10 percent; and $B$, cumulative precipitation totals for April 21-25, 2008, and locations of U.S. Geological Survey streamgages in lowa with peak streamflows that had an annual exceedance probability less than 10 percent. 
precipitation for this 25-day period was more than $20 \mathrm{in}$. in several locations (fig. 12). The rainfall amounts for this period are considered extreme by the NWS, which determined the annual exceedance probabilities to be between 0.1 to 0.2 percent for the observed rainfall in parts of Iowa, east-central Illinois, and south-central Indiana and less than 0.1 percent for isolated areas in Iowa (fig. 13) (Geoffrey M. Bonnin, National Oceanic and Atmospheric Administration, National Weather Service, Office of Hydrologic Development, written commun., 2008). New June total precipitation records were set at 66 sites in the Midwest (Midwestern Regional
Climate Center, 2008). The record precipitation produced 77 peak-of-record streamflows at USGS streamgages during June, particularly in Iowa (39 peak-of-record streamflows) and Wisconsin (19 peak-of-record streamflows). The USGS streamgage at Cedar Rapids, Iowa (USGS streamgage 05464500 ), recorded a peak streamflow of $140,000 \mathrm{ft}^{3} / \mathrm{s}$ on June 13 that was 92 percent greater than the previous peakof-record streamflow $\left(73,000 \mathrm{ft}^{3} / \mathrm{s}\right)$ set in 1961 , and the peak stage of $31.12 \mathrm{ft}$ was $11 \mathrm{ft}$ above the previous peak-of-record stage of $20.00 \mathrm{ft}$ set in 1929 (table 5). Other peak-of-record streamflows were observed at USGS streamgages in Illinois,

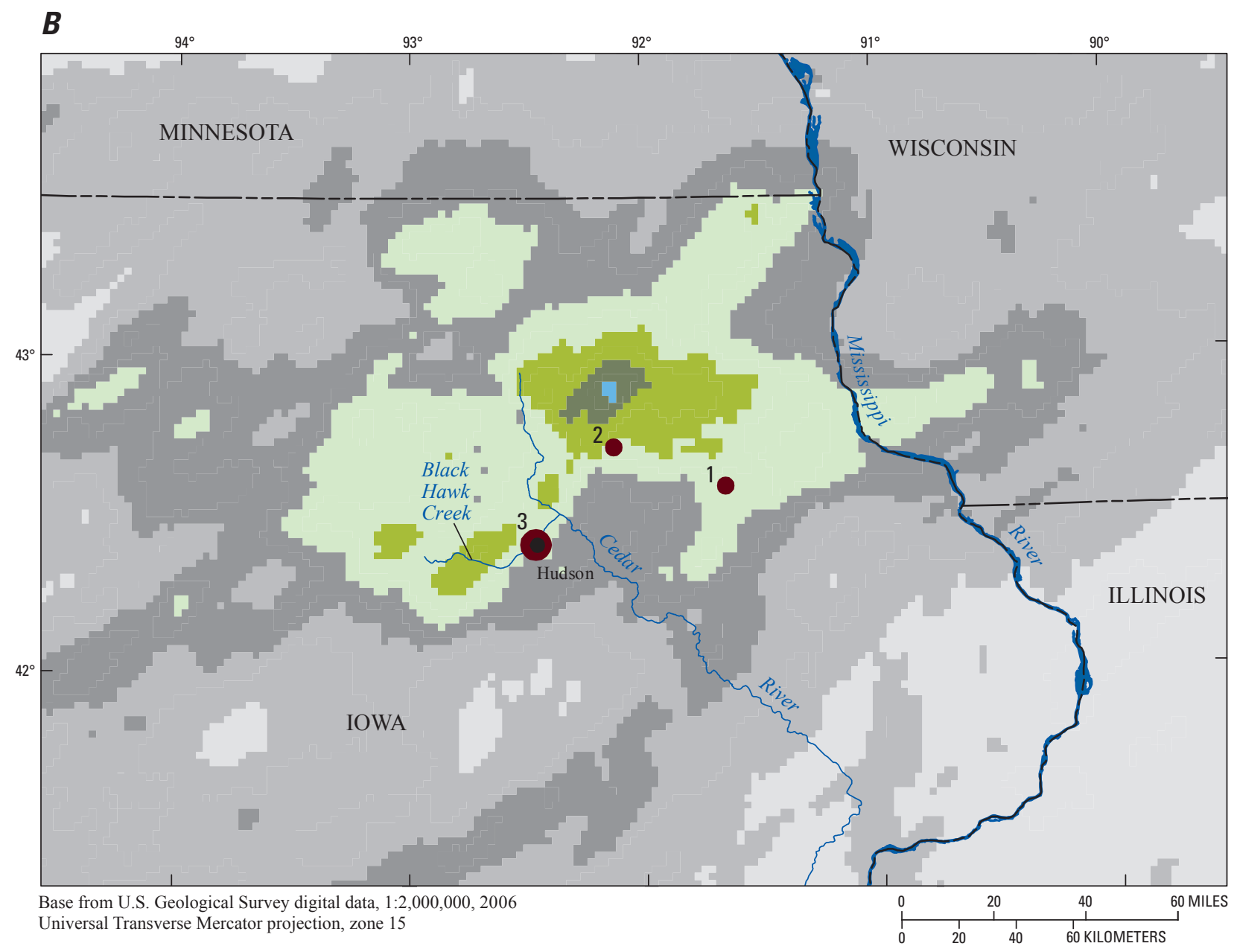

EXPLANATION

Precipitation, in inches-
Interval 1 and 2 inches

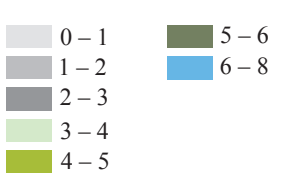

Flood annual exceedance probability (AEP),

in percent-Number is site identifier (table 4).

Not all ranges are represented on map
- No data
- Greater than 10
$4.0-10$
$2.0-4.0$

Figure 11. Cumulative precipitation totals for $A$, April 7-11, 2008, and locations of U.S. Geological Survey streamgages in Arkansas, Missouri, and Oklahoma with peak streamflows that had an annual exceedance probability less than 10 percent; and $B$, cumulative precipitation totals for April 21-25, 2008, and locations of U.S. Geological Survey streamgages in lowa with peak streamflows that had an annual exceedance probability less than 10 percent.-Continued 


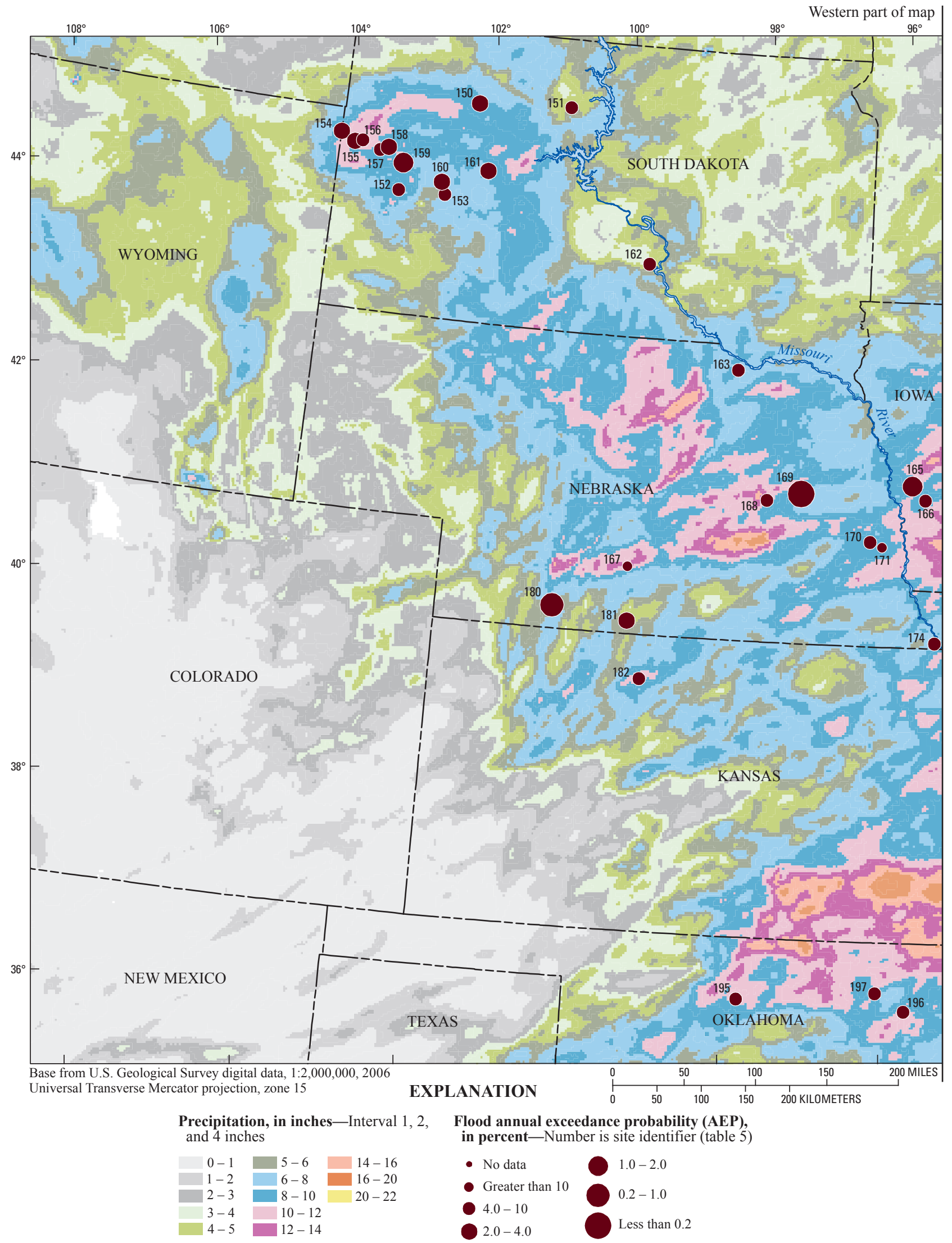

Figure 12. Cumulative precipitation totals for May 21 through June 14, 2008, and locations of U.S. Geological Survey streamgages in several Midwestern States with peak streamflows that had an annual exceedance probability less than 10 percent. 


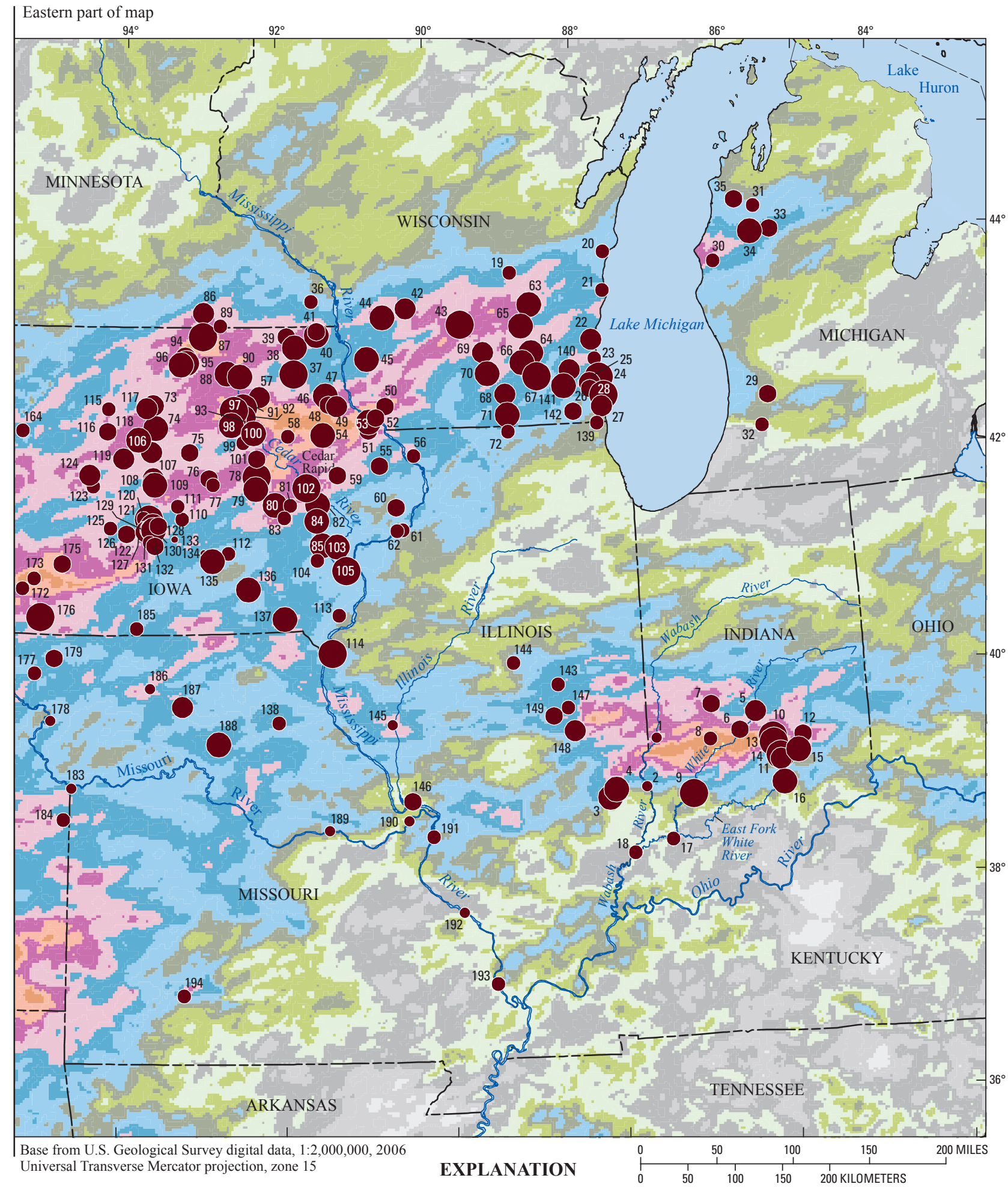

Precipitation, in inches-Interval 1, 2, Flood annual exceedance probability (AEP), and 4 inches

in percent-Number is site identifier (table 5)

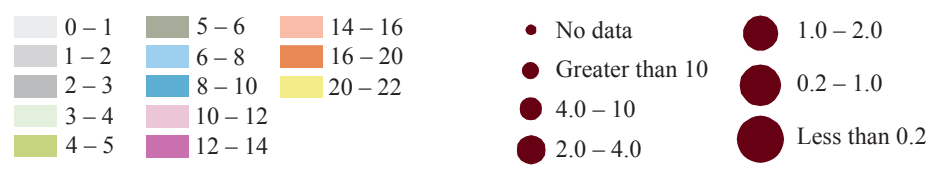

Figure 12. Cumulative precipitation totals for May 21 through June 14, 2008, and locations of U.S. Geological Survey streamgages in several Midwestern States with peak streamflows that had an annual exceedance probability less than 10 percent.-Continued 
Indiana, Michigan, Nebraska, Oklahoma, and South Dakota. Some locations in Indiana received a third or fourth round of flooding (fig. 14).

July proved to be no drier in southern Iowa and northern Missouri, which had two periods of substantial precipitation and subsequent flooding. Slightly more than 8 in. of precipitation occurred in south-central Iowa during July 5-8, 2008 (fig. 15A), causing peak streamflows on some small and mid-size streams on the order of 2-percent AEP, including the Chariton River near Moulton, Iowa (USGS streamgage 06904010, table 6). More abundant precipitation, as much as
17 in., over a much wider area between July 17 and July 28, 2008 (fig. 15B) fell on Iowa and Missouri. The later July precipitation produced new peak-of-record streamflows at USGS streamgages on the Salt and Chariton Rivers in Missouri (table 6).

Hurricanes Gustav and Ike initiated substantial precipitation events in September. The remnants of Hurricane Gustav passed over the Midwest during September 1-5, 2008, by tracking through Arkansas, Missouri, Illinois, and Michigan. Arkansas received the brunt of the precipitation as more than $12 \mathrm{in.} \mathrm{of} \mathrm{rainfall} \mathrm{occurred} \mathrm{during} \mathrm{this} \mathrm{period} \mathrm{(fig.} \mathrm{16A).}$

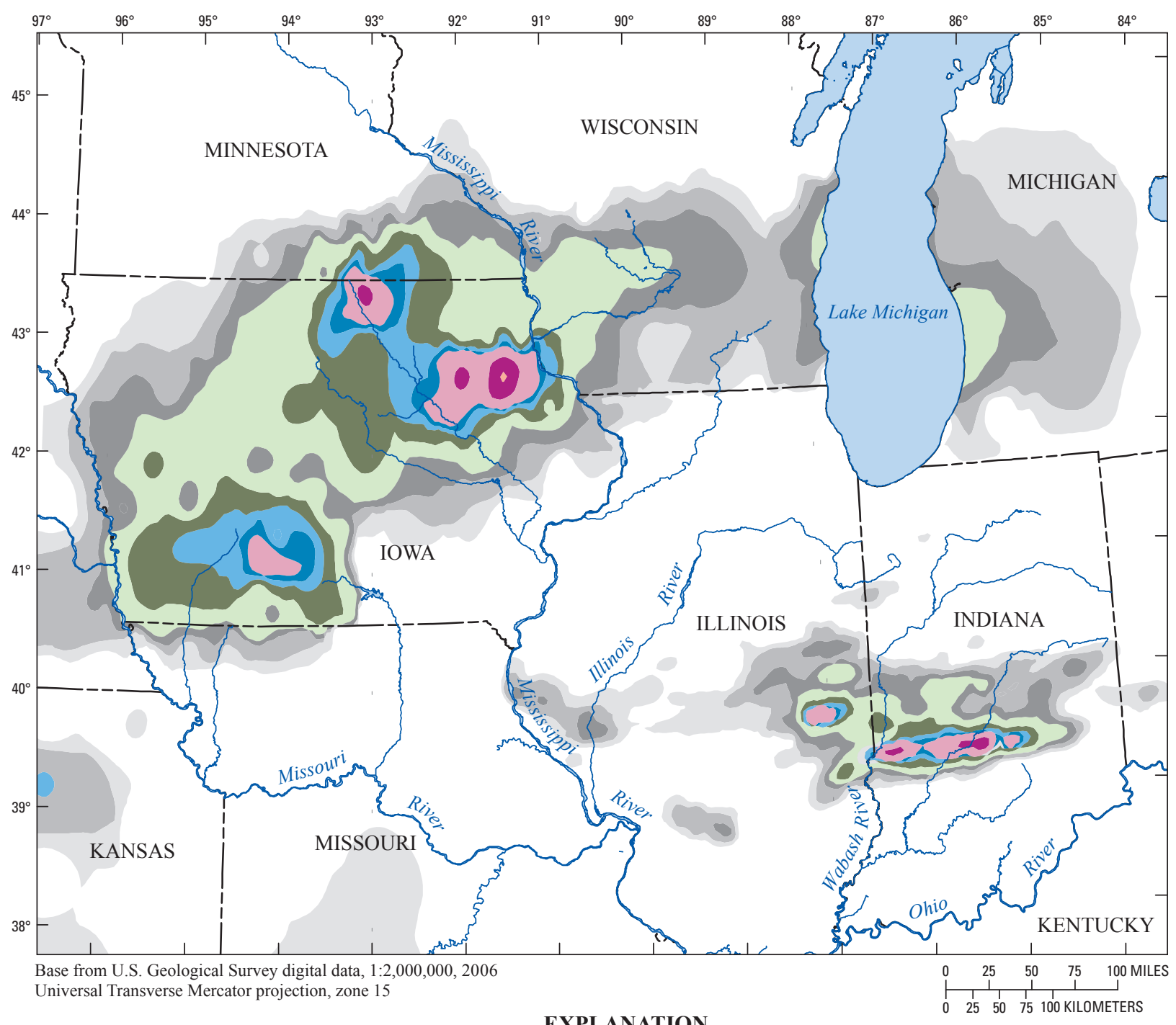

EXPLANATION

Rainfall annual exceedance probability, in percent

\begin{tabular}{|l|l|}
\hline $20-33$ & $0.67-1$ \\
$10-20$ & $0.5-0.67$ \\
$5-10$ & $0.2-0.5$ \\
$2-5$ & $0.1-0.2$ \\
$1-2$ & Less than 0.1
\end{tabular}

Figure 13. Annual exceedance probability for the rainfall total from May 23, 2008, to June 12, 2008 (revised from Geoffrey M. Bonnin, NOAA, National Weather Service, Office of Hydrologic Development, written commun., 2008) 


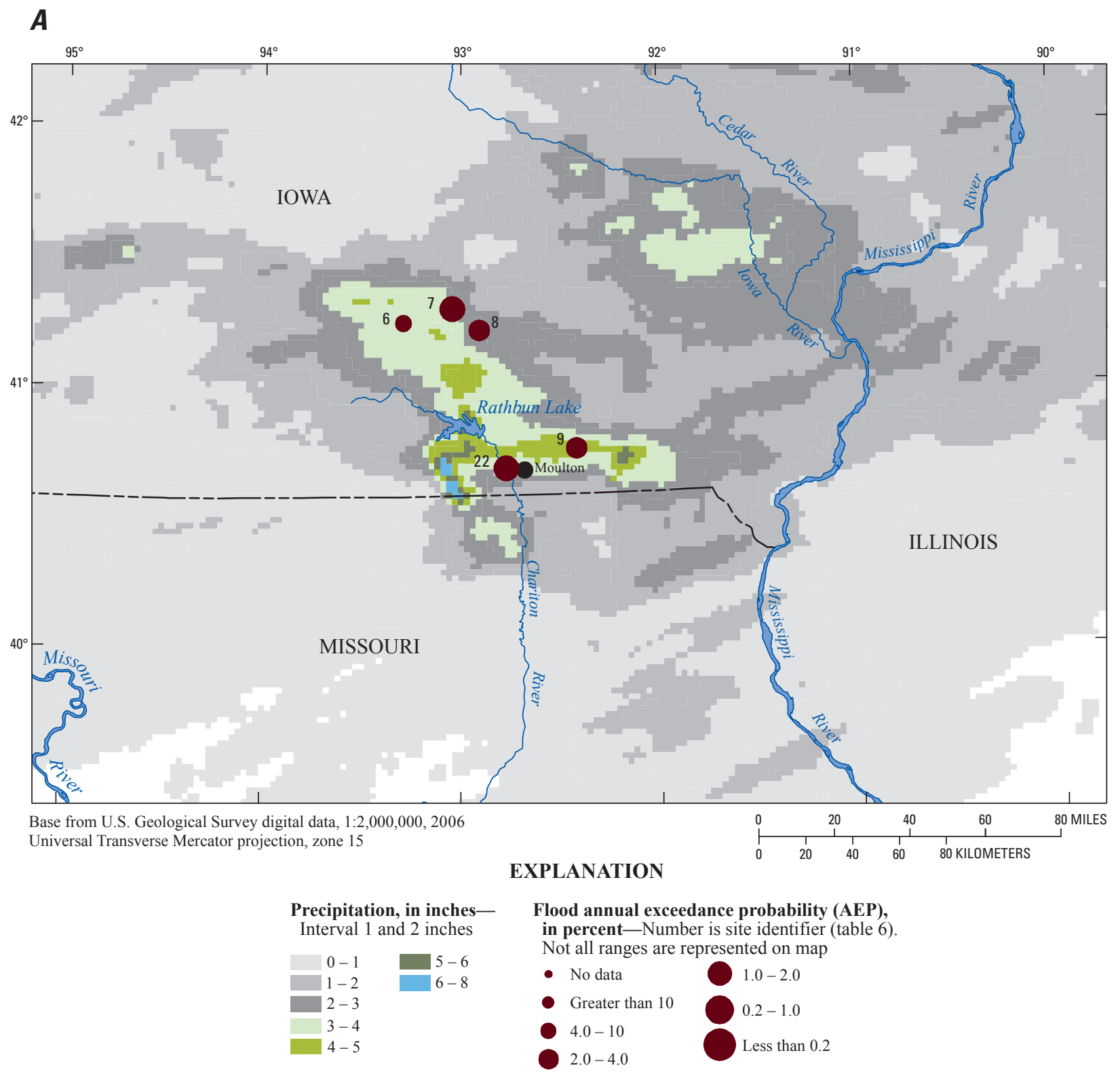

Figure 15. Cumulative precipitation totals for $A$, July 5-8, 2008, and locations of U.S. Geological Survey streamgages in lowa with peak streamflows that had an annual exceedance probability less than 10 percent; and $B$, cumulative precipitation totals for July 17-28, 2008, and locations of U.S. Geological Survey streamgages in lowa and Missouri with peak streamflows that had an annual exceedance probability less than 10 percent. 


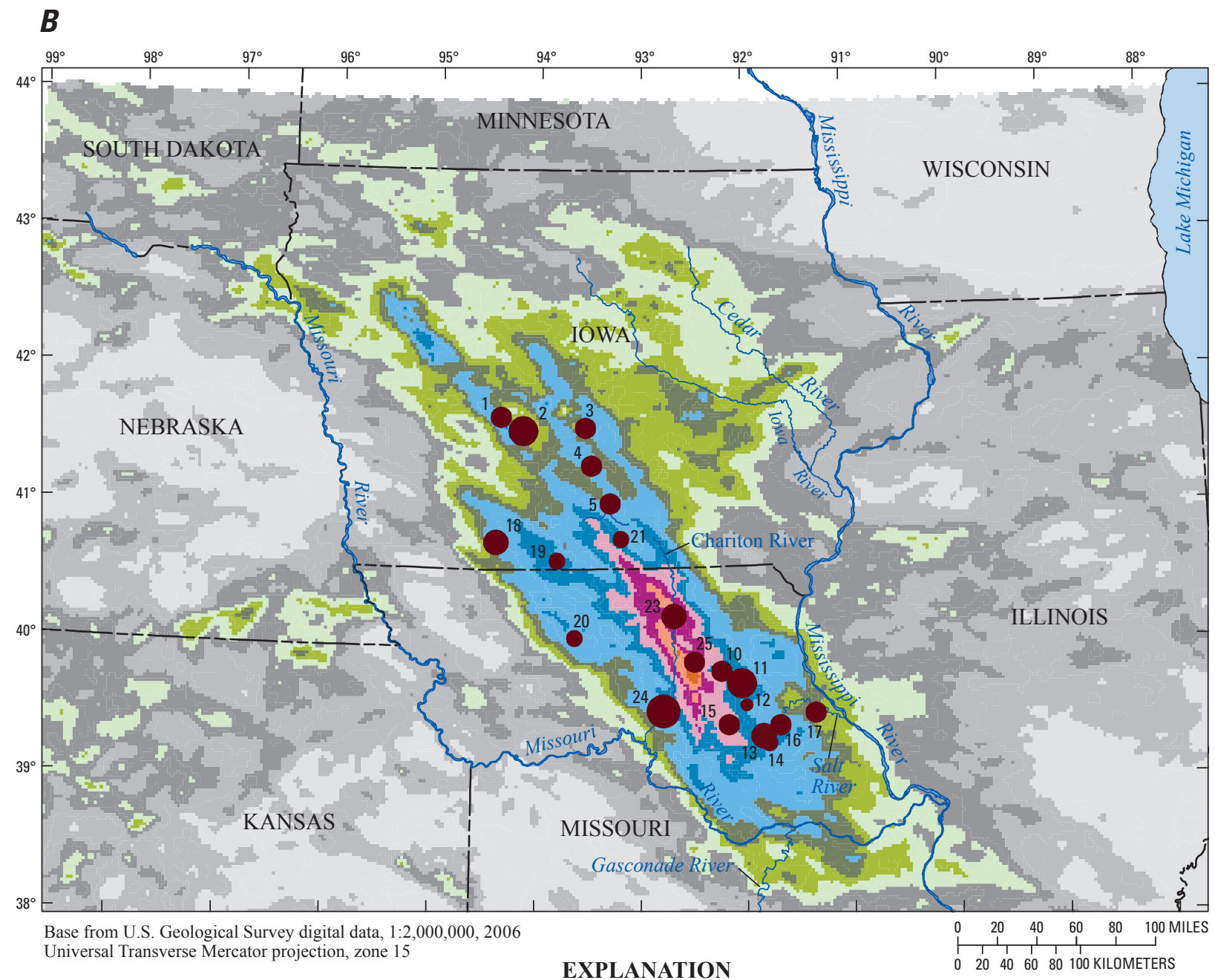

Flood annual exceedance probability (AEP), in percent-Number is site identifier (table 6). Not all ranges are represented on map
- No data
- Greater than 10
$4.0-10$
$2.0-4.0$
$1.0-2.0$
$0.2-1.0$
Less than 0.2

Figure 15. Cumulative precipitation totals for $A$, July 5-8, 2008, and locations of U.S. Geological Survey streamgages in lowa with peak streamflows that had an annual exceedance probability less than 10 percent; and $B$, cumulative precipitation totals for July 17-28, 2008,and locations of U.S. Geological Survey streamgages in lowa and Missouri with peak streamflows that had an annual exceedance probability less than 10 percent.-Continued 
$\boldsymbol{A}$

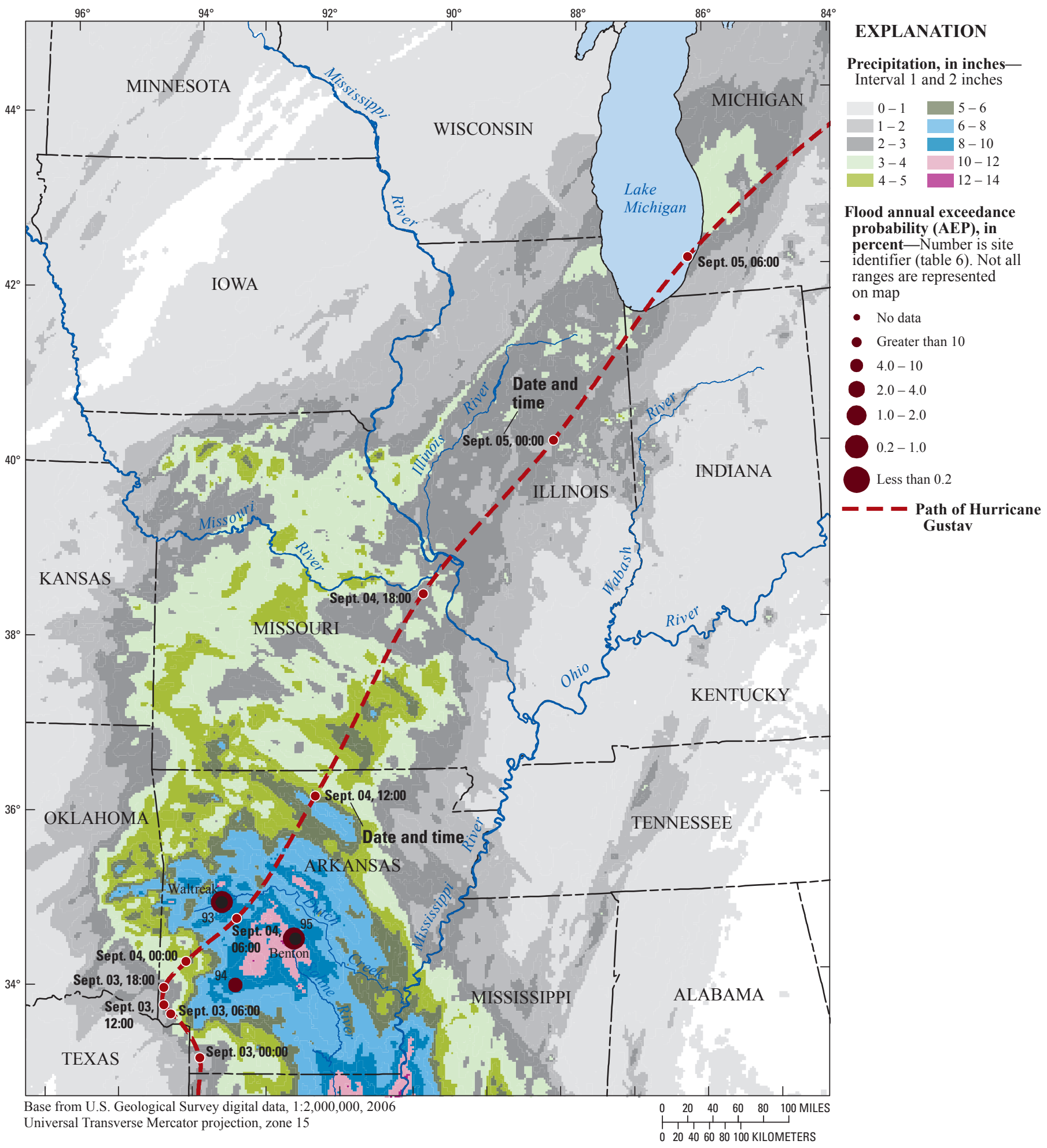

Figure 16. Cumulative precipitation totals for $A$, September 1-5, 2008, the path of the remnants of Hurricane Gustav, and locations of U.S. Geological Survey streamgages in Arkansas with peak streamflow that had an annual exceedance probability less than 10 percent; and $B$, cumulative precipitation totals for September 11-15, 2008, the path of the remnants of Hurricane Ike, and locations of U.S. Geological Survey streamgages in Illinois, Indiana, lowa, Kansas, Michigan, Missouri, and Oklahoma with peak streamflows that had an annual exceedance probability less than 10 percent. 


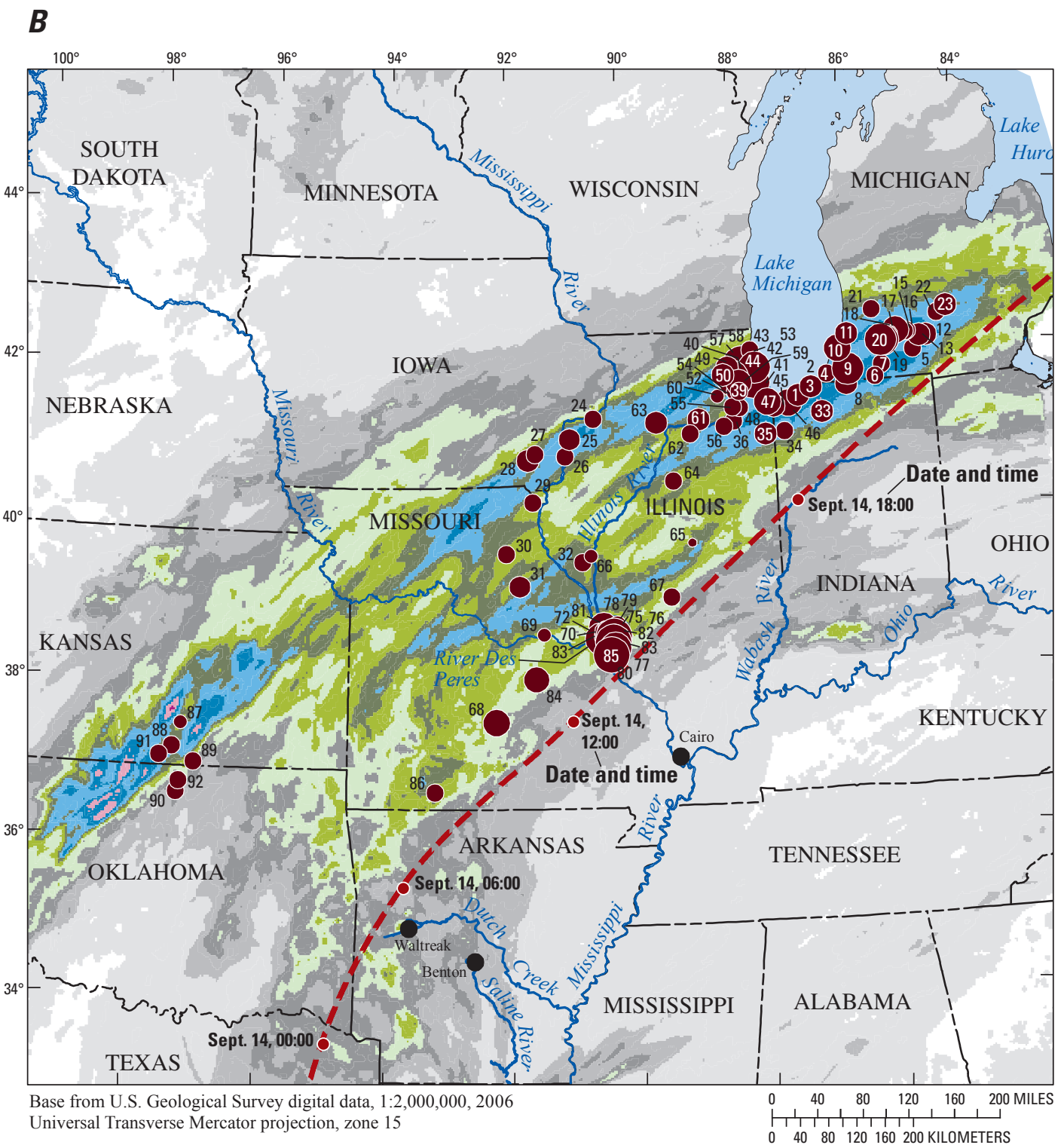
Precipitation, in inches-
Interval 1 and 2 inches
Flood annual exceedance probability (AEP),
$0-1 \quad 5-6$
in percent-Number is site identifier (table 7)

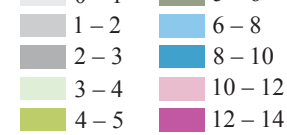
- No data
$1.0-2.0$
- Greater than 10
4.0-10
$0.2-1.0$
$2.0-4.0$
Less than 0.2

EXPLANATION

$--\infty-$ Path of Hurricane Ike

Figure 16. Cumulative precipitation totals for $A$, September 1-5, 2008, the path of the remnants of Hurricane Gustav, and locations of U.S. Geological Survey streamgages in Arkansas with peak streamflow that had an annual exceedance probability less than 10 percent; and $B$, cumulative precipitation totals for September 11-15, 2008, the path of the remnants of Hurricane Ike, and locations of U.S. Geological Survey streamgages in Illinois, Indiana, lowa, Kansas, Michigan, Missouri, and Oklahoma with peak streamflows that had an annual exceedance probability less than 10 percent.-Continued 


\section{Flooding: Comparison with Historic Floods}

Placing the magnitude of a flood into context is desirable for comparison with previous floods. Ranking the observed 2008 peak streamflows at USGS streamgages against previous streamflow peaks of record indicates the relative magnitude of the 2008 floods (tables 1-7). In many locations, the 2008 streamflow peaks were the largest to occur in many decades. For example, the June 2008 flood on the Cedar River at Cedar Rapids, Iowa, (USGS streamgage 05464500 , table 5) is the largest streamflow ever recorded at this site and exceeds the previous peak-of-record stage by more than $11 \mathrm{ft}$. During 2008, 147 USGS streamgages recorded new peak-of-record streamflows, with 77 peak-of-record streamflows set during the June floods alone.

To gain perspective of the magnitude of 2008 peak streamflows compared with previous annual peak streamflows, the annual streamflow peaks through time were plotted from data recorded at six USGS streamgages across the Midwest (fig. 17). Also included in these plots is the estimated value of the 1-percent AEP flood quantile at these six sites. The benchmark for major flooding on many of the major tributaries and much of the main stem of the upper Mississippi River (above Cairo, Illinois) is the 1993 flood; however, for some of the tributaries, and certainly for the rivers in Arkansas, Indiana, Illinois, Michigan, Nebraska, Oklahoma, and South Dakota, floods other than 1993 flood serve as the benchmarks for record flooding as evidenced in figure 17. The 2008 flood hydrographs for selected USGS streamgages in the Midwest are presented in figure 18 with previous record flood hydrographs to enable comparisons. Although the June 2008 floods were record setting on some of the Mississippi River tributaries in Iowa, Wisconsin, Illinois, and Missouri, [for example, Cedar River at Cedar Rapids, Iowa (fig. 18A) and Iowa River at Iowa City, Iowa (fig. 18B)], the Mississippi River main stem did not have record-setting streamflows at the USGS streamgages. The Mississippi River at Keokuk, Iowa (fig. 18C) peak streamflow in June 2008 ranked second in 131 years of systematic streamflow records, just $8,000 \mathrm{ft}^{3} / \mathrm{s}$ shy of the 1993 record peak streamflow of $446,000 \mathrm{ft}^{3} / \mathrm{s}$. Contrast the near peak-of-record streamflow at Keokuk, Iowa (ranked 2nd in 131 years of record), with the 2008 peak streamflow $184 \mathrm{mi}$ downstream on the Mississippi River at St. Louis, Missouri. The 2008 peak streamflow ranked only 25th in the 147 years of systematic streamflow records, well below the 1993 record peak streamflow (fig. 18D). The 2008 streamflow on the Mississippi River at St. Louis was lower primarily because of the smaller streamflow contribution from the Missouri River in 2008, which contributed streamflow of as much as 750,000 ft $3 / \mathrm{s}$ in 1993 (Parrett and others, 1993) compared with a maximum streamflow during June 2008 of
$302,000 \mathrm{ft}^{3} / \mathrm{s}$ at the USGS streamgage at St. Charles, Missouri (table 5).

\section{Flooding: Annual Exceedance Probability}

Although ranking floods helps to illustrate the relative magnitude of the floods, it has limited use for evaluating the future risk of flooding. Determining the AEP requires floodprobability analysis, which involves determining the parameters needed to estimate a probability distribution from a set of observed peak streamflow data. The probability distribution relates probability to the magnitude of a certain size flood being equaled or exceeded.

Selection of the probability distribution and the process for fitting the parameters of the distribution may vary depending on the underlying characteristics of the data. For consistency, Federal agencies that estimate flood frequencies follow standard guidelines, known as Bulletin 17B (Interagency Advisory Committee on Water Data, 1982), which recommend the use of the log-Pearson type III (LPIII) distribution and the "method of moments" for estimating the distribution parameters (mean, standard deviation, and skewness of the data). The analysis is based on annual peak streamflow data. For USGS streamgages, the data are available from the USGS National Water Information System database (U.S. Geological Survey, 2008).

In previous flood reports (for example, Chin and others, 1975; Parrett and others, 1993; Holmes and Kupka, 1997), flood probabilities were expressed as flood frequencies by listing the T-year recurrence interval for a particular flood quantile (for example, the "100-year flood"). Use of the T-year recurrence interval to describe flood probability is now discouraged by the USGS because it tends to confuse the general public. A T-year recurrence interval is sometimes interpreted to imply that there is a set time interval between floods of a specific magnitude when, in fact, floods are random processes that are best understood using probabilistic terms. The use of an AEP percentage for a flood is now recommended because of the clear communication, by the terminology, that the peak streamflow is being characterized by its probability or chance of occurrence. The reader can easily convert from the AEP to the T-year recurrence interval by simply taking the reciprocal of the AEP. For example, a 1-percent AEP flood corresponds to the streamflow magnitude that is equaled or exceeded by a probability (expressed as a decimal) of 0.01 in any given year. The reciprocal of 0.01 is 100 , thus the T-year recurrence interval for the 1-percent AEP flood is the 100-year flood. Equivalence of selected AEP and recurrence intervals are as follows: 

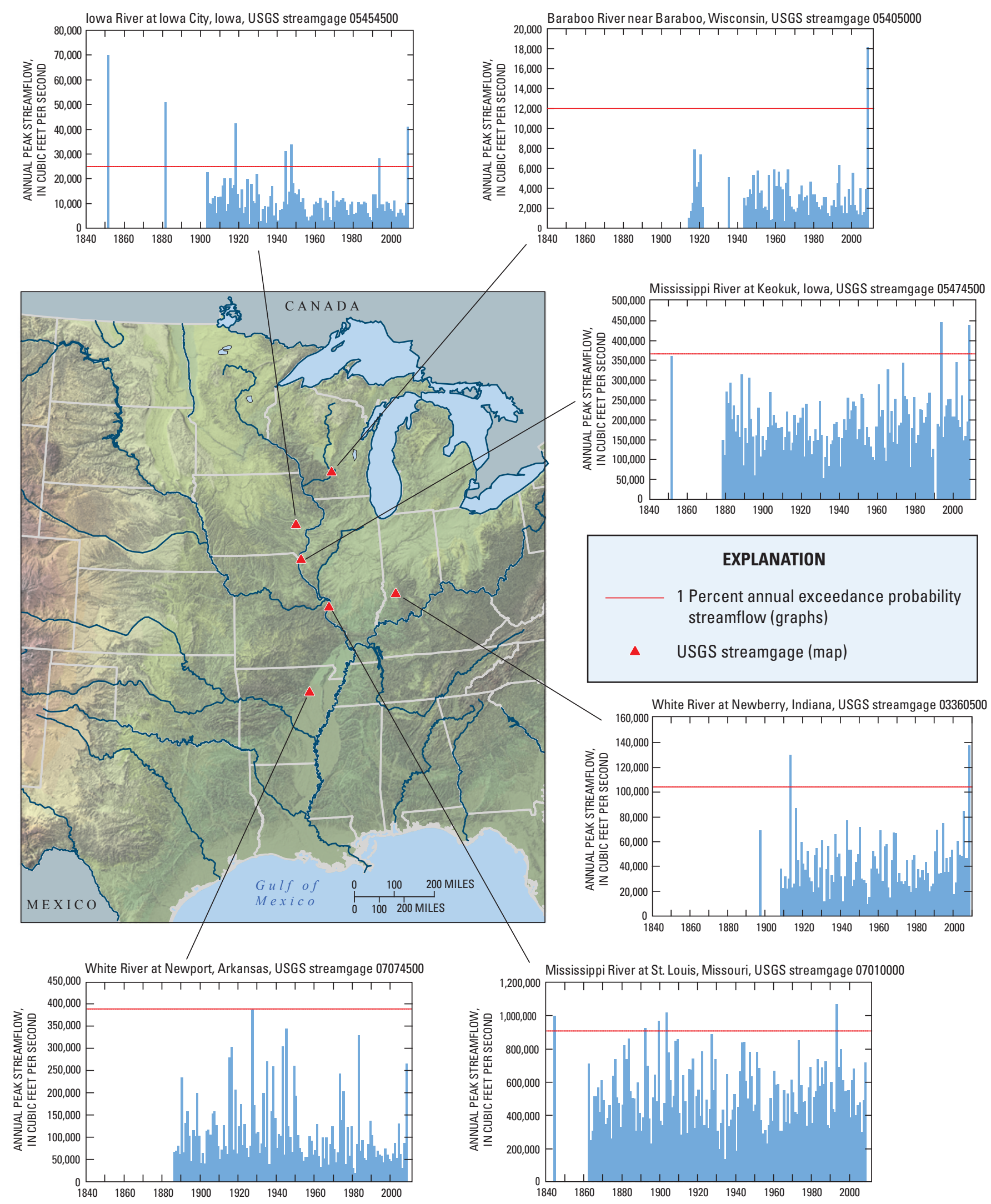

Figure 17. Annual peak streamflows for the period of record up to 2008 and the 1-percent annual exceedance probability at selected U.S. Geological Survey streamgages in the Midwest. 

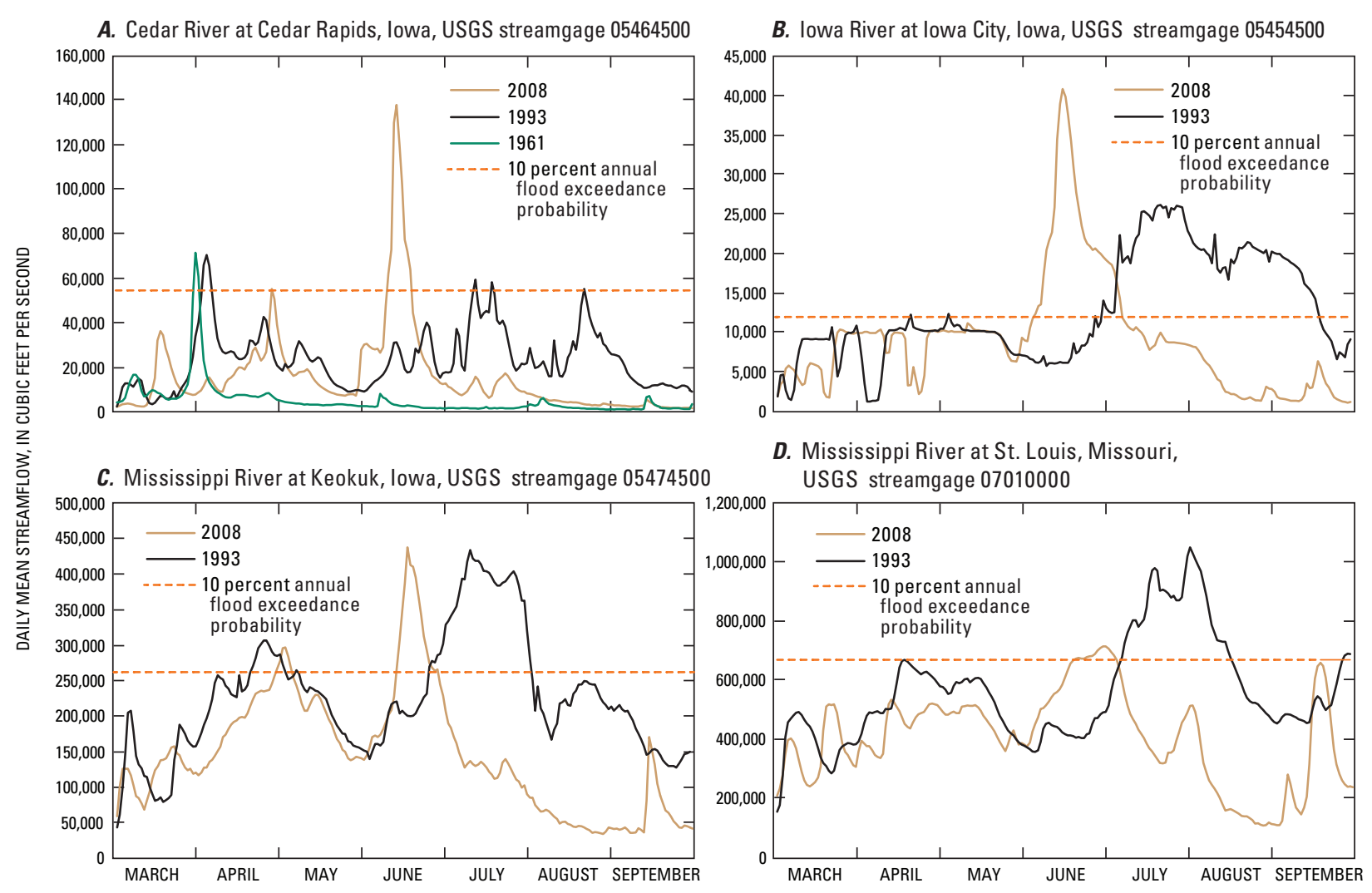

Figure 18. Streamflow for selected U.S. Geological Survey streamgages for the 2008 flood period and previous major floods, and the 10-percent annual exceedance probability for each site.

\begin{tabular}{|c|c|}
\hline $\begin{array}{c}\text { AEP } \\
\text { (percent) }\end{array}$ & $\begin{array}{c}\text { Recurrence interval } \\
\text { (years) }\end{array}$ \\
\hline 50 & 2 \\
\hline 20 & 5 \\
\hline 10 & 10 \\
\hline 4 & 25 \\
\hline 2 & 50 \\
\hline 1 & 100 \\
\hline 0.2 & 500 \\
\hline
\end{tabular}

The reliability of an AEP flood quantile from Bulletin 17B methods may be expressed as a "variance of prediction" and is computed by using the asymptotic formula given by Cohn and others (2001), with the addition of the mean-squared error of generalized skew (Griffis and others, 2004). The variance of prediction varies as a function of the length of record, the fitted flood-probability distribution parameters (mean, standard deviation, and weighted skew), and the accuracy of the method used to determine the regional skew component of the weighted skew. The variance of prediction generally decreases with length of record and the fit of the LPIII distribution.
Besides estimating AEP flood quantiles by Bulletin 17B methods, another way to obtain an AEP flood quantile estimate is by using regional regression equations (RRE). RRE are developed by using regression techniques that relate the floodprobability data at many streamgages in a particular region to the basin characteristics of the streams being monitored by the streamgages (Jennings and others, 1994). For any location along a stream (gaged or ungaged), a user can enter the basin characteristics (drainage area, basin slope, and so on) as independent variables into the equations and compute various streamflow characteristics, such as the 1-percent AEP flood quantile. The variance of prediction from the regional regression is a function of the RRE and the values of the independent variables used to develop the streamflow estimate from the RRE. The variance generally increases with departure of the actual values from the mean values of the independent variables. The USGS uses software programs, such as GLSNET (Generalized Least Squares NETwork analysis; Tasker and Stedinger, 1989), to compute the model error variance.

The optimal estimate of the AEP flood quantile for a gaged site is determined by weighting the AEP flood quantile estimate determined from the Bulletin 17B methods with the AEP flood quantile estimate determined from the RRE. The 
weights are inversely proportional to the variances of prediction, yielding the weighted estimator:

$$
\begin{aligned}
& \log Q_{P, O P T}=\frac{\left(\operatorname{Var}[R R E]^{*} \log Q_{P, L P I I}+\operatorname{Var}[L P I I I] * \log Q_{P, R R E}\right)}{(\operatorname{Var}[R R E]+\operatorname{Var}[L P I I I])} \\
& \text { where } \\
& Q_{P, O P T} \quad \text { is the optimal estimate of AEP flood quantile } \\
& \text { for a particular probability of flooding } \\
& \text { (p) (Interagency Advisory Committee on } \\
& \text { Water Data, 1982, Appendix 8); } \\
& \operatorname{Var}[R R E] \quad \text { is the variance of the RRE estimate of } \\
& \text { the AEP flood quantile for a particular } \\
& \text { probability of flooding }(\mathrm{p}) \text {; } \\
& Q_{P, L P I I} \quad \text { is the Bulletin 17B method estimate of } \\
& \text { the AEP flood quantile for a particular } \\
& \text { probability of flooding }(p) \text {; } \\
& \operatorname{Var}[L P I I] \quad \text { is the variance of the Bulletin 17B estimate } \\
& \text { of the AEP flood quantile for a particular } \\
& \text { probability of flooding (p); and } \\
& Q_{P, R R E} \quad \text { is the RRE estimate of the AEP flood quantile } \\
& \text { for a particular probability of flooding }(p) \text {. }
\end{aligned}
$$

Previous USGS reports have expressed the accuracy of RREs in terms of equivalent years of record and used these estimates with the length of record at the streamgage to combine RRE and LPIII AEP flood quantile estimates (for example, Hodge and Tasker, 1995; Soong and others, 2004; Ries and Dillow, 2006). The length of record, however, can fail to account for the true variance of LPIII flood-probability estimates. For example, the length of record fails to account for any improvement in the information provided by the regional skew. Furthermore, flood-probability distributions computed from two different streamgaging records of the same length may not be of equal reliability because of differences in underlying variances of the streamflow records for each site. For example, a small drainage basin may have dynamic, more highly varied records and may be more difficult to accurately measure the streamflow than a large drainage basin; hence, the LPIII distributions in a small drainage basin could be expected to have larger variances than in a large drainage basin. More importantly, the equivalent years-of-record concept, although relatively easy to grasp, misconstrues the relation between the AEP flood quantile estimates and the variances. Using estimated variances provides a more natural characterization of the underlying uncertainty of the various streamflow estimates.

The optimal (weighted) estimates of the AEP flood quantiles corresponding to the 4-percent, 2-percent, 1-percent, and 0.2-percent AEP, along with their respective 95-percent confidence limits, for most of the streams in the Midwest that were flooded during the January to September 2008 time frame, are given in tables 1-7. Presenting this information for the streams in this report allows the reader to better assess the uncertainty of the AEP for each stream in the tables. During January through September 2008, peak streamflows at 26 USGS streamgages had a less than 0.2-percent AEP, and peak streamflows at 67 USGS streamgages had an AEP in the range of 0.2 to 1 percent.

\section{Effects of the 2008 Flooding on Annual Exceedance Probability Estimates}

The calculation of AEP flood quantiles by the guidelines published in Bulletin 17B is dependent on annual peak streamflow data from USGS streamgages. As more data become available, the AEP flood quantile estimates are affected. As a result, the AEP flood quantiles for the various AEP values (for example, 50-percent, 2-percent, and 1-percent AEP) change through time at each site. The effects of changing the length of the annual peak streamflow record on AEP flood quantiles are shown for selected sites in figure 19, which has the moving unweighted (not weighted with RRE estimate) AEP flood quantile plotted through time. A minimum of 10 years of annual peak streamflow data was needed for these sites before the first unweighted AEP flood quantile was computed by Bulletin 17B methods. Thereafter, the moving unweighted AEP flood quantiles for the 50-percent, 2-percent, and 1-percent AEP were computed using the Bulletin 17B guidelines for each successive year, keeping all previous annual peak streamflow data in the analysis. By examining the time series for each graph, it is apparent that increases in the 1-percent and 2-percent unweighted AEP flood quantile occur with each new major flood, followed by slight decreases in the years following each major flood. The 50-percent unweighted AEP flood quantile estimate is mostly insensitive to major floods.

Inclusion of the 2008 flood-peak streamflow in the analysis increases the 2-percent and 1-percent unweighted AEP flood quantile estimate for each of the six selected USGS streamgages (fig. 19). The unregulated streams in the Midwest with more than 10 years of record and that had peak streamflows during 2008 with an estimated AEP less than 1 percent are presented in figure 20. Including the 2008 peak streamflow in the flood-probability analysis increased the estimate of the 1-percent unweighted AEP flood quantile anywhere from 20 percent to more than 100 percent for streamgages with less than 25 years of record (fig. 20). In contrast, streamgages with more than 80 years of record had a less than 10 percent increase in the 1-percent unweighted AEP flood quantile, inferring that the longer the period of record used for the flood-probability analysis, the less pronounced the effect of including the 2008 flood data. A similar observation can be made for the confidence limits. All other factors being equal, one can reasonably conclude that as the length of record increases, the instability in the AEP flood quantile estimate decreases and the confidence limits narrow, resulting in a decrease in the level of uncertainty in the AEP flood quantile estimate. For this report, the 2008 peak streamflows were included in all flood-probability analyses to determine the AEP flood quantile estimates provided in tables 1-7. 
Bark River near Rome, Wisconsin, USGS streamgage 05426250

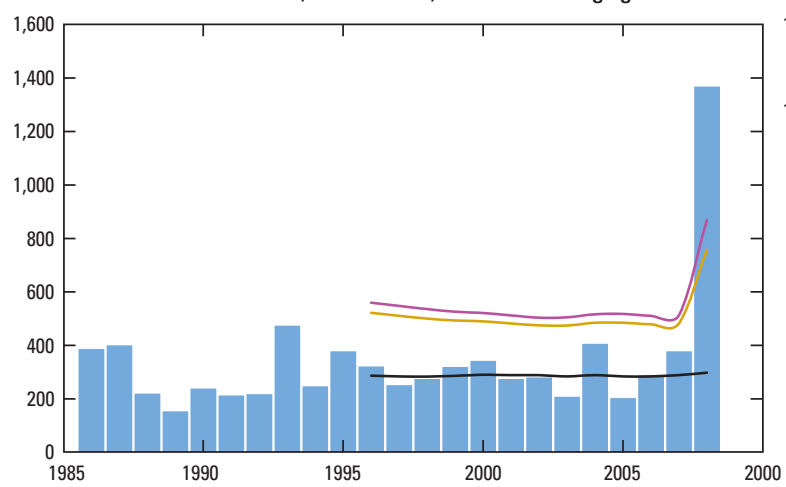

Chariton River near Prairie Hill, Missouri, USGS streamgage 06905500

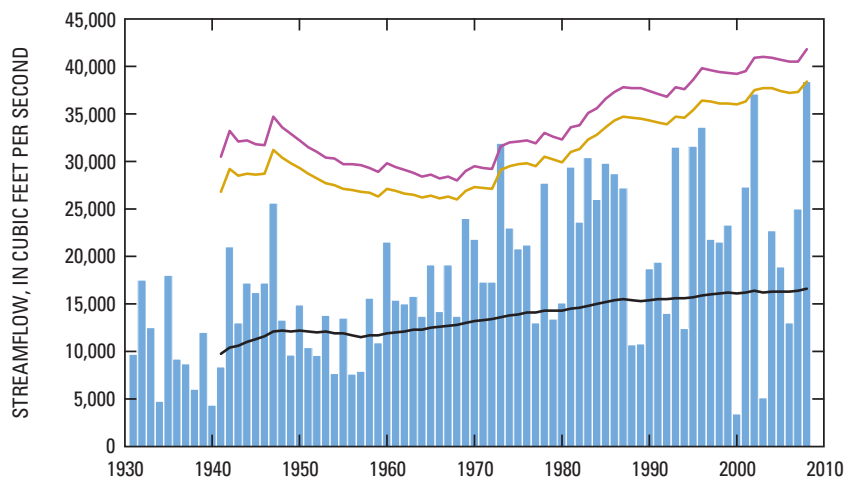

Rock River at Afton, Wisconsin, USGS streamgage 05430500

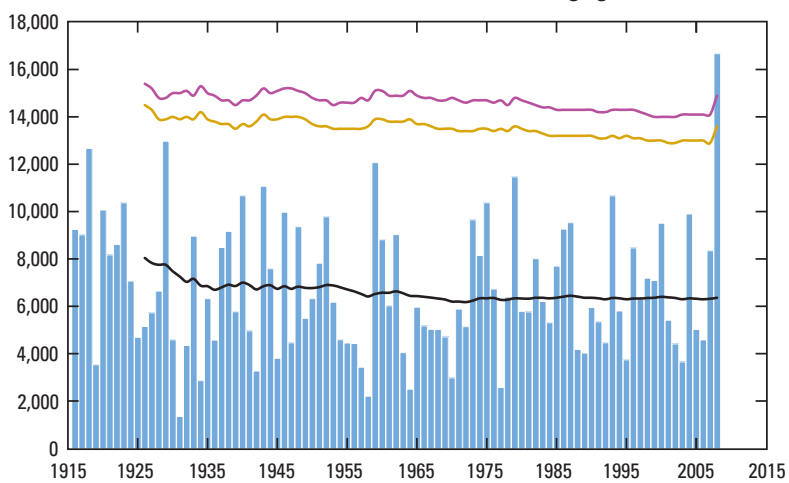

Cedar River at Cedar Rapids, Iowa, USGS streamgage 05464500

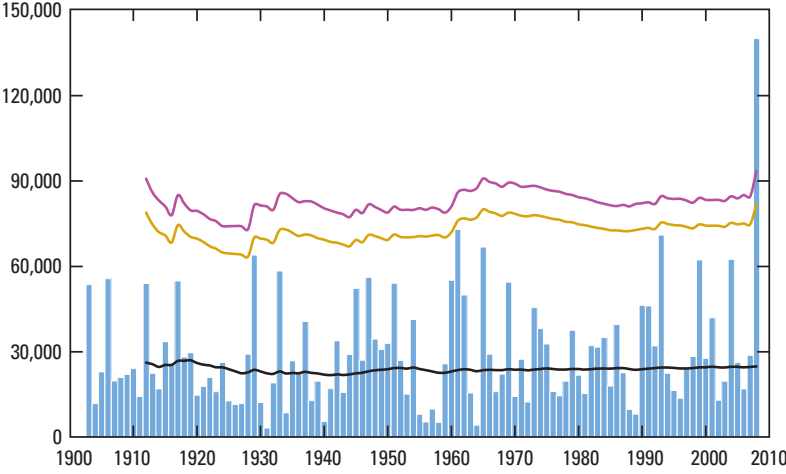

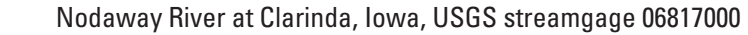

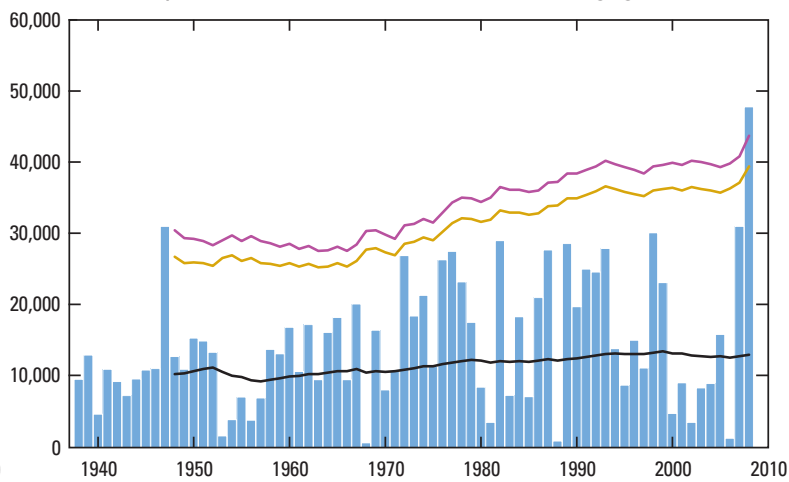

Shell Rock River at Shell Rock, lowa, USGS streamgage 05462000

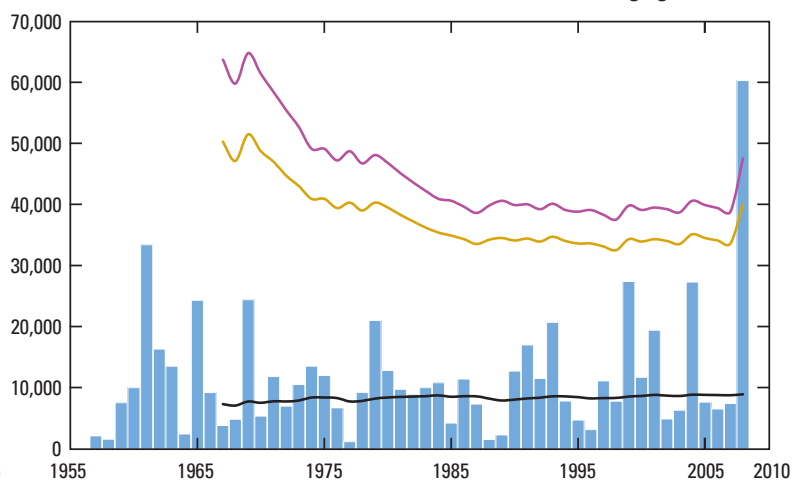

\section{EXPLANATION}

Annual peak streamflow

— Moving 1-percent annual exceedance probability flood quantile

Moving 2-percent annual exceedance probability flood quantile

Moving 50-percent annual exceedance probability flood quantile

Figure 19. Effects of annual peak streamflows on moving 50-percent, 2-percent, and 1-percent unweighted annual exceedance probability flood quantiles through time at selected U.S. Geological Survey streamgages. 


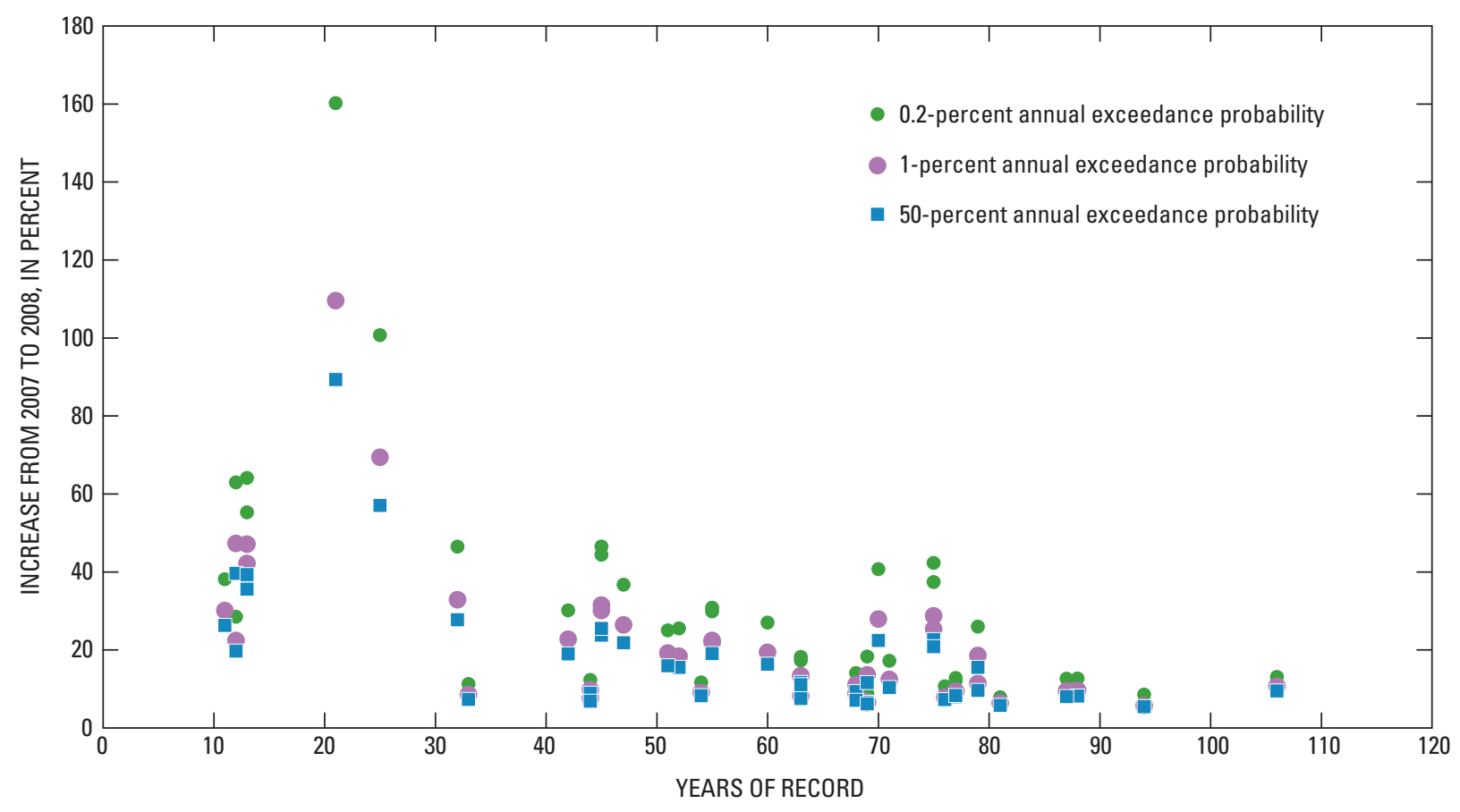

Figure 20. Increase in the 0.2-percent, 1-percent, and 50-percent unweighted annual exceedence probability flood quantiles for unregulated streams in the Midwest with more than 10 years of record when 2008 peak streamflow data were included in the flood-probability analysis.

\section{Trends in Flood Maxima}

Trends in peak streamflows are important to investigate, as a trend may indicate to emergency and infrastructure managers changes in levels of risk to public safety. The annual peak-streamflow time-series data were analyzed for selected USGS streamgages in the Midwest to determine the presence and subsequent magnitude of trends through time at each site. Only trend magnitudes were computed with no effort to conduct null hypothesis significance testing (NHST), as much discussion in recent literature has focused on problems with NHST (Nichols, 2001) and the issue of long-term persistence (Cohn and Lins, 2005).

The trend magnitudes were computed based on the Sen slope estimator (Sen, 1968) using the MAKESENS application from the Finnish Meteorological Institute (Salmi and others, 2002). The Sen slope, also known as the Kendall-Theil robust line, is a nonparametric estimate of trend magnitude slope for a univariate time series when the time interval is constant (equally spaced).

$$
f(t)=M_{\mathrm{q}} t+B
$$

where

$f(\mathrm{t}) \quad$ is the increasing or decreasing function of time for the trend magnitudes of the peak streamflows used in the investigation,

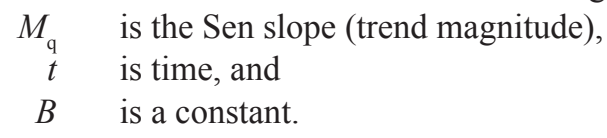

The Sen slope is the median slope of all pairwise comparisons with each pairwise difference divided by the number of years separating the records. To determine the Sen slope estimate in equation 2, the slopes of all data pairs are calculated:

$$
M_{\mathrm{j}, \mathrm{k}}=\frac{\left(\mathrm{x}_{\mathrm{k}}-\mathrm{x}_{\mathrm{j}}\right)}{\Delta \mathrm{t}_{\mathrm{j}, \mathrm{k}}} \quad \text { for } \mathrm{j}=1, \ldots, \mathrm{n}-1 ; \mathrm{j}<\mathrm{k} \leq \mathrm{n}
$$

where

$$
\begin{aligned}
M_{\mathrm{j}, \mathrm{k}} & \text { is the slope between data points } \mathrm{x}_{\mathrm{j}} \text { and } \mathrm{x}_{\mathrm{k}} ; \\
\mathrm{x}_{\mathrm{j}} & \text { is the data measurement at time } j ; \\
\mathrm{x}_{\mathrm{k}} & \text { is the data measurement at time } k \text {; and } \\
\Delta \mathrm{t}_{\mathrm{j}, \mathrm{k}} & \text { is the change in time between observations. }
\end{aligned}
$$

The Sen slope, $M_{\mathrm{q}}$, is equal to the median value of all the $M_{\mathrm{j}, \mathrm{k}}$.

The streamgages selected for trend analysis were selected from the streamgages that had peak streamflows less than 10-percent AEP in 2008 and met the criteria outlined in Hodgkins and others (2007). The criteria stipulate that the streamgage must have at least 50 years of data with no more than 5 percent missing and that the stream must not be 


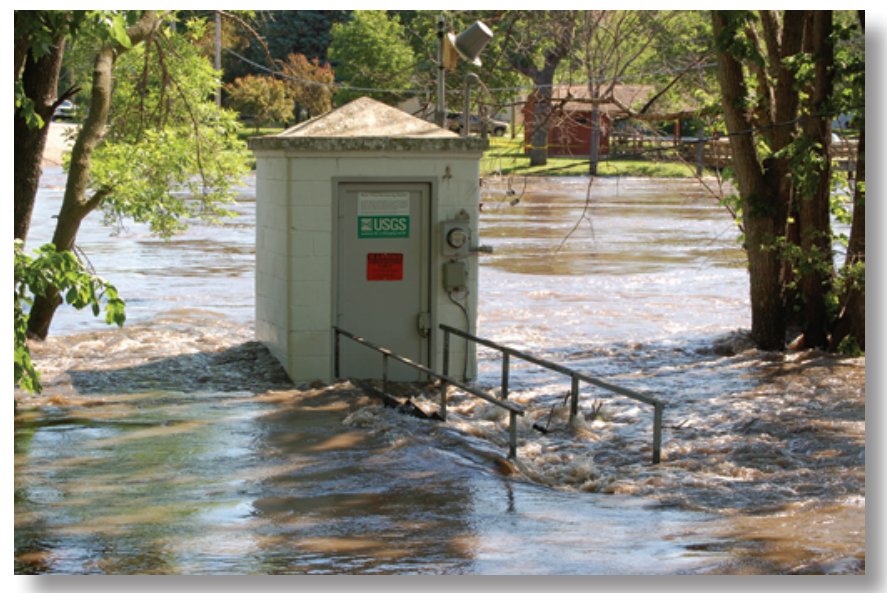

regulated by the presence of a substantial dam or other waterdiversion and control structure. The minimum timeframe of 50 years of record is arbitrary. The USGS streamgages that did not meet these criteria were eliminated from the analyses. In the Midwestern States included in this investigation, 147 streamgages on unregulated streams met the criteria and were included in the computation of trend magnitudes of annual peak streamflows.

For comparison of streamgages with varying basin sizes, the Sen slope for each streamgage was divided by the median annual peak streamflow value to determine the percentage of

4 Streamgage 05462000, Shell Rock River at Shell Rock, lowa. Photograph by Don Becker, USGS.

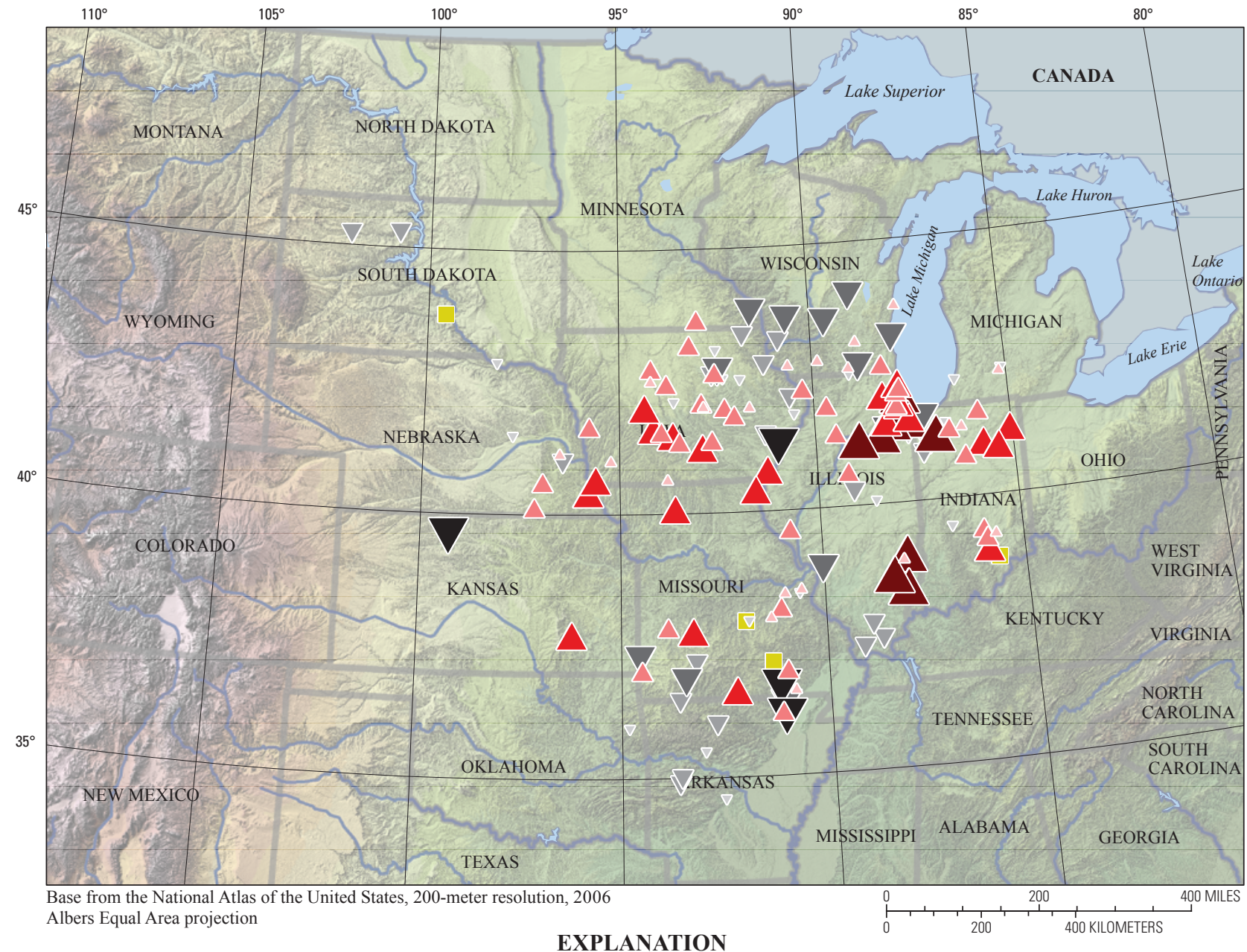

Percent change of the median flood, per year

\begin{tabular}{|c|c|c|}
\hline Positive & Negative & No change \\
\hline$\triangle \quad 0-0.3$ & $\nabla \quad-0.3-0$ & 0 \\
\hline $0.4-0.6$ & $-0.7--0.4$ & \\
\hline $0.7-1.0$ & $\nabla-1.9--0.8$ & \\
\hline $1.1-1.7$ & $-3.1--2.0$ & \\
\hline
\end{tabular}

Figure 21. Percentage changes in the median annual peak streamflow values for selected U.S. Geological Survey streamgages on unregulated streams with data from 1958 to 2007. 
change with respect to the median annual peak streamflow at each streamgage. Examination of the trend magnitude (scaled by median annual peak flood streamflow) from1958 to 2007 does not indicate a systematic trend for the Midwest in either direction. Of the 147 streamgages, 83 had an upward trend, 60 had a downward trend, and 4 had no trend (fig. 21). The clustering of upward trends in magnitude (positive percentages) in northeastern Illinois and northwestern Indiana (fig. 21) likely is explained partially by increased urbanization in the Chicago metropolitan area between 1958 and 2007. A clustering of downward trends in magnitude (negative percentages) occurred in areas of eastern Iowa, southern Wisconsin, and southern Illinois. An additional analysis was conducted on 14 streamgages on unregulated streams with annual peak streamflow data from 1918 to 2007; of these 14 sites, 10 streamgages had an upward trend (fig. 22).

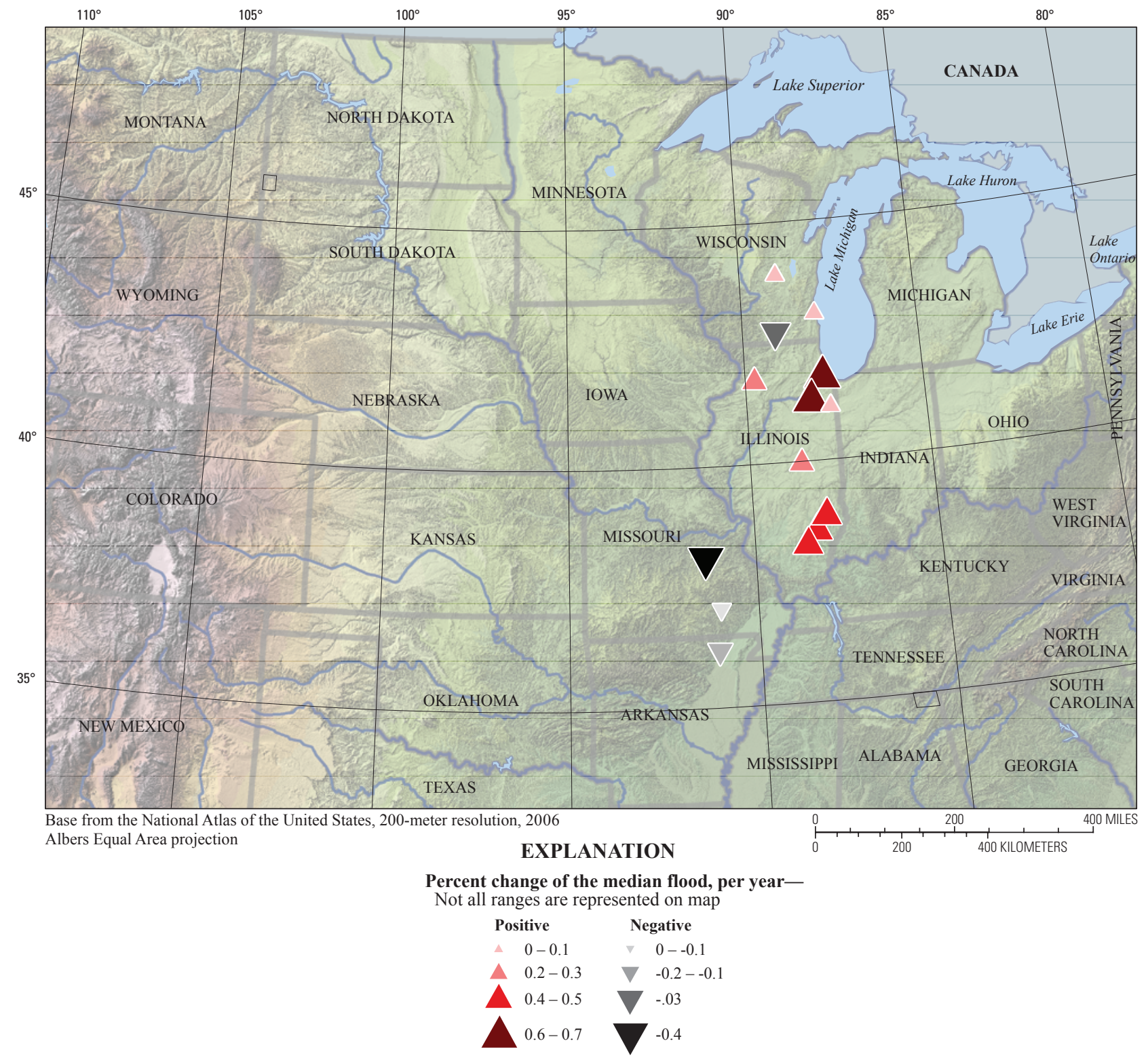

Figure 22. Percentage changes in the median annual peak streamflow values for selected U.S. Geological Survey streamgages on unregulated streams with data from 1918 to 2007. 


\section{Summary}

Above-average precipitation occurred throughout much of the United States Midwest during late 2007, which left soils extremely wet or saturated as the 2007-2008 winter months approached. Melting of the above-average snow accumulations in the upper Midwest provided a perfect setting for enhanced runoff by keeping the soil saturated and streams flowing well above baseflow throughout spring 2008. Heavy precipitation occurred in January in parts of Illinois and Indiana and initiated the first of many rounds of flooding in the Midwest. Discrete episodes of extreme or heavy precipitation resulted in flooding in parts of the Midwest during the months of January-April, June, July, and September, 2008. New total precipitation records were set at 106 National Weather Service rain gages during January through June 2008. During June 2008, new monthly total precipitation records were set at 66 rain gages, with precipitation totals in the range of 0.2-percent to 0.1-percent annual exceedance probability in parts of Illinois, Indiana, and Iowa.

In 2008, more than 147 USGS Midwestern streamgages had peak-of-record streamflows. Of these 147 peak-of-record streamflows, 77 were set in June alone, and 39 of the 77 were in Iowa.

Rare floods (less than 0.2-percent chance of exceedance) were recorded at USGS streamgages at 26 sites, and 67 streamgages recorded peak streamflows having an annual exceedance probability between 0.2 percent and 1 percent. Recurrent flooding in Indiana set new records at several streamgages during the months of January, February, March, June, and September 2008. The June flooding was by far the most severe and widespread, causing damage in Illinois, Indiana, Iowa, Kansas, Michigan, Minnesota, Missouri, Nebraska, Oklahoma, South Dakota, and Wisconsin.

Trend magnitudes were computed at 147 unregulated Midwest streamgages. The computed trend magnitudes and percentages of change in the median annual peak streamflow values indicated that although clustering of increasing and decreasing trends occurred, no consistent trend was evident across the Midwest.

\section{References Cited}

Adams, Barry, 2008, Hope returns to Lake Delton: Madison, Wisconsin, Wisconsin State Journal, December 5, 2008.

Benson, M.A., and Dalrymple, Tate, 1967, General field and office procedures for indirect measurements: U.S. Geological Survey Techniques of Water-Resources Investigations, book 3, chap. A1, 30 p.
Chin, E.H., Skelton, John, and Guy, H.P., 1975, The 1973 Mississippi River basin flood: compilation and analysis of meteorologic, streamflow, and sediment data: U.S. Geological Survey Professional Paper 937, 137 p.

Cohn, T.A., Lane, W.L., and Stedinger, J.R., 2001, Confidence intervals for expected moments algorithm flood quantile estimates: Water Resources Research, v. 37, no. 6, p. 1,695-1,706.

Cohn, T.A., and Lins, H.F., 2005, Nature's style: Naturally trendy: Geophysical Research Letters, v. 32, L23402, 5 p.

Eash, D.A., 2001, Techniques for estimating flood-frequency discharges for streams in Iowa: U.S. Geological Survey Water-Resources Investigations Report 00-4233, 88 p.

Fitzpatrick, F.A., Peppler, M.C., Walker, J.F., Rose, W.J., Waschbusch, R.J., and Kennedy, J.L., 2008, Flood of June 2008 in southern Wisconsin: U.S. Geological Survey Scientific Investigations Report 2008-5235, 24 p.

Fodor, Eric, 2009, Flooding is a continual problem: Harrisburg, IL, Harrisburg Daily Register, March 17, 2009.

Funkhouser, J.E., and Eng, Ken, 2008, Floods of selected streams in Arkansas, spring 2008: U.S. Geological Survey Fact Sheet 2008-3103, 4 p.

Gillerman, Margaret, 2008, University City flood victims plead for help: St. Louis, Missouri, St. Louis Post Dispatch, September 23, 2008.

Griffis, V.A., Stedinger, J.R., and Cohn, T.A., 2004, Log Pearson type 3 quantile estimators with regional skew information and low outlier adjustments: Water Resources Research, v. 40, W07503, 17 p.

Hjelmfelt, A.T., Jr., and Cassidy, J.J., 1975, Hydrology for engineers and planners: Ames, Iowa, Iowa State University Press, $210 \mathrm{p}$.

Hodge, S.A., and Tasker, G.D., 1995, Magnitude and frequency of floods in Arkansas: U.S. Geological Survey Water-Resources Investigations Report 95-4224, 52 p.

Hodgkins, G.A., Dudley, R.W., and Aichele, S.S., 2007, Historical changes in precipitation and streamflow in the U.S. Great Lakes Basin, 1915-2004: U.S. Geological Survey Scientific Investigations Report 2007-5118, 31 p.

Holmes, R.R., Jr., and Kupka, A.L., 1997, Floods of July 18-20, 1996, in northern Illinois: U.S. Geological Survey Open-File Report 97-425, 29 p.

Indiana NewsCenter, 2008, 125-million flood damage at Columbus Hospital, accessed August 31, 2008, at http:// www.indianasnewscenter.com/news/local/20601219.html. 
Indianapolis Star, 2008, Assessing the damage, accessed August 31, 2008, at http://www.indystar.com/apps/pbcs.dll/ article? AID=/20080615/LOCAL/806150400/1001/NEWS.

Interagency Advisory Committee on Water Data, 1982, Guidelines for determining flood flow frequency: Reston, Virginia., U.S. Geological Survey, Bulletin 17B of the Hydrology Subcommittee, Office of Water Data Coordination, 183 p., available online at http://water.usgs.gov/osw/ bulletin17b/dl flow.pdf.

Jennings, M.E., Thomas, T.O., Jr., and Riggs, H.C., 1994, Nationwide summary of U.S. Geological Survey regional regression equations estimating magnitude and frequency of floods for ungaged sites: U.S. Geological Survey WaterResources Investigations Report 94-4002, 196 p.

Langbein, W.B., and Iseri, K.T., 1960, General introduction and hydrologic definitions: U.S. Geological Survey WaterSupply Paper 1541-A, 29 p.

Midwestern Regional Climate Center, 2008, Recordsetting precipitation totals in the Midwest: accessed on December 15, 2008, at http://mcc.sws.uiuc.edu/news/ releases/2008/20080702_Precipitation\%20Records.pdf.

Morlock, S.E., Menke, C.D., Arvin, D.V., and Kiim, M.H., 2008, Flood of June 7-9, 2008, in central and southern Indiana: U.S. Geological Survey Open-File Report 2008-1322, 15 p.

National Climatic Data Center, 2008, Climate-radar data inventories: accessed on September 15, 2009, at http://www4.ncdc.noaa.gov/cgi-win/wwcgi. dll? WWDI getstate $U S A$.

National Weather Service, 2009, Central United States flooding of June 2008: Service assessment: Silver Spring, MD, National Oceanic and Atmospheric Administration, National Weather Service, $50 \mathrm{p}$

National Weather Service, 2008a, Advanced Hydrologic Prediction Service, current 1-day observed precipitation, January 8, 2008: National Oceanic and Atmospheric Administration, National Weather Service, accessed January 8, 2008, at http://water.weather.gov/.

National Weather Service, 2008b, NOAA's source for snow information: National Oceanic and Atmospheric Administration, National Weather Service, National Operational Hydrologic Remote Sensing Center, accessed on February 18, 2008, at http://www.nohrsc.nws.gov/.

Nichols, Neville, 2001, The insignificance of significance testing: Bulletin of American Meteorology Society, v. 81, no. 5, p. $981-986$.

O'Connor, J.E., and Costa, J.E., 2003, Large floods in the United States: where they happen and why: U.S. Geological Survey Circular 1245, $13 \mathrm{p}$.
Parrett, Charles, Melcher, N.B., and James, R.W., Jr., 1993, Flood streamflows in the upper Mississippi River basin, 1993: U.S. Geological Survey Circular 1120-A, 14 p.

Rabbitt, M.C., 1989. The United States Geological Survey, 1879-1989: U.S. Geological Survey Circular 1050, 52 p., available online at $h t t p: / / p u b s . u s g s . g o v / c i r c / c 1050 /$ index. htm.

Rantz, S.E., Measurement and computation of streamflow: volumes 1 and 2: U.S. Geological Survey Water-Supply Paper 2175, $632 \mathrm{p}$.

Ries, K.G., III, and Dillow, J.J.A., 2006, Magnitude and frequency of floods on nontidal streams in Delaware: U.S. Geological Survey Scientific Investigations Report 2006-5146, 59 p.

Salmi, T., Määttä, A., Anttila, P., Ruoho-Airola, T., and Amnell, T., 2002, Detecting trends of annual values of atmospheric pollutants by the Mann-Kendall test and Sen's slope estimates-The excel template application MAKESENS: Helsinki, Finland, Finnish Meteorological Institute Report 31, 35 p.

Sando, S.K., Driscoll, D.G., and Parrett, Charles, 2008, Peakflow Frequency Estimates Based on Data through Water Year 2001 for Selected Streamflow-Gaging Stations in South Dakota: U.S. Geological Survey Scientific Investigations Report 2008-5104, 367 p. available online at http:// pubs.usgs.gov/sir/2008/5104.

Sen, P.K., 1968, Estimates of the regression coefficient based on Kendall's tau: Journal of American Statistical Association, vl. 63, p. 1,379-1,389.

Soong, D.T., Ishii, A.L., Sharpe, J.B., and Avery, C.F., 2004, Estimating flood-peak streamflow magnitudes and frequencies for rural streams in Illinois: U.S. Geological Survey Scientific Investigations Report 2004-5103, 147 p.

Tasker, G.D., and Stedinger, J.R., 1989, An operational GLS model for hydrologic regression: Journal of Hydrology, v. 111, p. 361-375.

U.S. Army Corps of Engineers , 2009, Iowa River regulated flow frequency study. U.S. Army Corps of Engineers, Rock Island, Illinois, October 2009, 65 p.

U.S. Army Corps of Engineers , 2004, Upper Mississippi River System flow frequency study. U.S. Army Corps of Engineers, Rock Island, Illinois, available online at http://www.mvr.usace.army.mil/pdw/pdf/flowfrequency/ Documents/FinalReport/default.asp.

U.S. Army Corps of Engineers, 2002, Regulated Frequency Curve and Pool Elevation Frequency Estimates for the Des Moines and Iowa River Basins, Iowa, Prepared for the Rock Island District Corps of Engineers by the Hydrologic Engineering Center, Davis, California, January 2002. 
U.S. Geological Survey, 2010, Flood Photo and Video Archive, White River at Calico Rock, Arkansas Video: U.S. Geological Survey, accessed on January 1, 2010 at http://water.usgs.gov/osw/floods/photo vid archive/ 2008 March/calicovideo.wmv.

U.S. Geological Survey, 2008, National Water Information System, peak streamflow for the Nation: U.S. Geological Survey Web interface, accessed on October 31, 2008, at http://nwis.waterdata.usgs.gov/usa/nwis/peak.
U.S. Geological Survey, 2007, WaterWatch-Current water resources conditions, map of real-time streamflow compared to historical streamflow for the day of the year (United States): U.S. Geological Survey, accessed on November 30, 2007, and February 28, 2008, at http://waterwatch.usgs.gov/.

Flooding on the West Fork Cedar River near Finchford, lowa. Photograph by Don Becker, USGS.

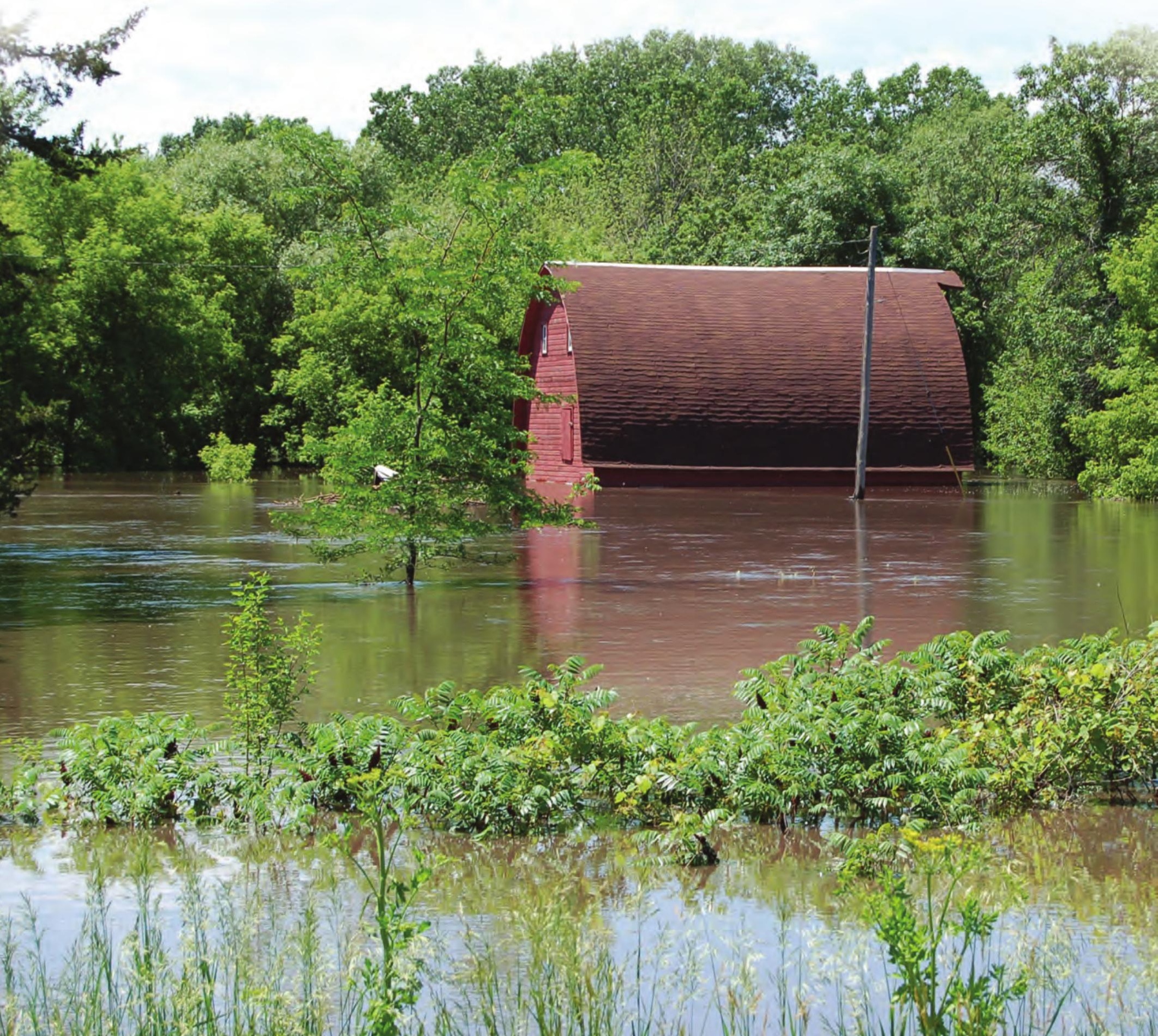




\section{Tables 1-7}

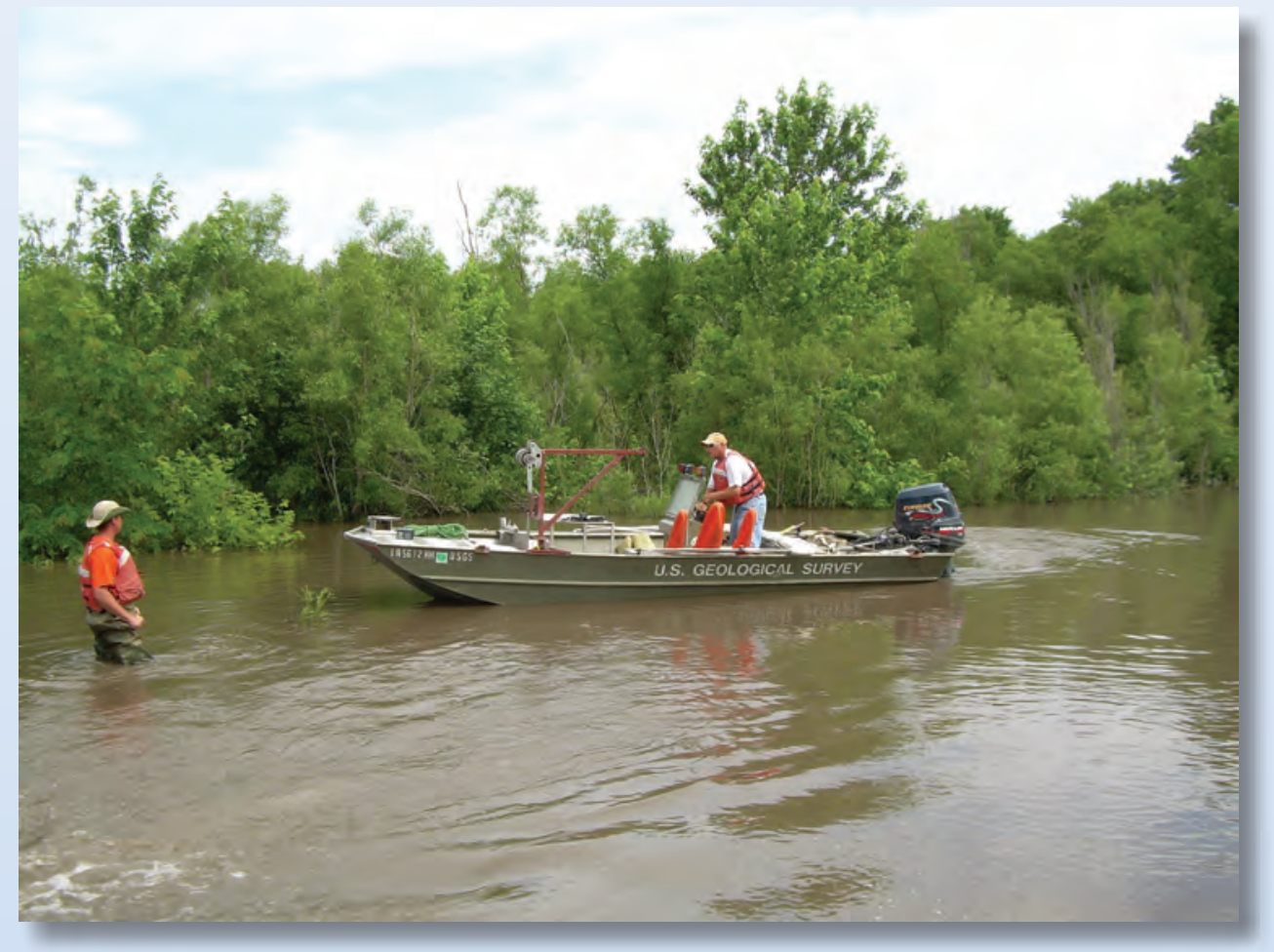

USGS hydrographers preparing to make a boat measurement of the streamflow coming across the road on the Cedar River near Conesville, lowa (USGS streamgage 05465000). Photograph by Scott Strader, USGS. 
Table 1. Summary of peak stages, streamflows, and flood-probability estimates for selected U.S. Geological Survey streamgages during January 2008.

[mi², square mile; ff, foot; ffis, cubic foot per second; AEP, annual exceedance probability; $<$, less than; --, no data; $>$, greater than $]$

\begin{tabular}{|c|c|c|c|c|c|c|c|c|c|c|}
\hline \multirow{3}{*}{$\begin{array}{c}\text { Site } \\
\text { number } \\
\text { (fig. 7) }\end{array}$} & \multirow{3}{*}{$\begin{array}{l}\text { Station } \\
\text { number }\end{array}$} & \multirow{3}{*}{ Station name } & \multirow{3}{*}{$\begin{array}{l}\text { Contributing } \\
\text { drainage } \\
\text { area } \\
\text { (mí) }\end{array}$} & \multicolumn{7}{|c|}{ Flood data } \\
\hline & & & & \multicolumn{3}{|c|}{ Previous maximum streamflow } & \multicolumn{4}{|c|}{ Flood of January 2008} \\
\hline & & & & Date & $\begin{array}{c}\text { Stage } \\
\text { (ft) }\end{array}$ & $\begin{array}{c}\text { Streamflow } \\
\left(\mathrm{ft}^{\mathrm{t}} \mathrm{s} / \mathrm{s}\right)\end{array}$ & $\begin{array}{l}\text { Ranke/ } \\
\text { annual } \\
\text { peaks }\end{array}$ & Date & $\begin{array}{l}\begin{array}{l}\text { Peak } \\
\text { stage } \\
\text { (ft) }\end{array} \\
\text { s. }\end{array}$ & $\begin{array}{l}\text { Peak } \\
\text { streamtlow } \\
\left.\left(t^{\prime}+s\right) / s\right)\end{array}$ \\
\hline 1 & 03328000 & Eel River at North Manchester, Ind. & 417 & $12 / 1990$ & 20.16 & 8,740 & (c) & 1/9/2008 & 13.88 & 7,950 \\
\hline 2 & 03328500 & Eel River near Logansport, Ind. & 789 & $02 / 1985$ & 12.68 & 17,700 & (c) & $1 / 10 / 2008$ & 11.26 & 13,300 \\
\hline 3 & 03330500 & Tippecanoe River at Oswego, Ind. & 113 & 03/1982 & 9.25 & d950 & (c) & 1/13/2008 & 8.51 & ${ }^{d} 650$ \\
\hline 4 & 03331500 & Tippecanoe River near Ora, Ind. & 856 & 06/1981 & 15.08 & 8,660 & $1 / 64$ & $1 / 10 / 2008$ & 15.63 & 9,290 \\
\hline 5 & 03333050 & Tippecanoe River near Delphi, Ind. & 1,869 & $12 / 1990$ & 12.87 & 22,100 & 1/20 & 1/8/2008 & 17.83 & 937,600 \\
\hline 6 & 03335500 & Wabash River at Lafayette, Ind. & 7,267 & 03/1913 & 32.90 & 190,000 & (') & $1 / 10 / 2008$ & 21.95 & ${ }^{\mathrm{d} 59,800}$ \\
\hline 7 & 03336000 & Wabash River at Covington, Ind. & 8,218 & 03/1913 & 35.10 & 200,000 & (c) & $1 / 11 / 2008$ & 25.99 & ${ }^{\mathrm{d} 56,700}$ \\
\hline 8 & 03341500 & Wabash River at Terre Haute, Ind. & 12,263 & 03/1913 & 31.20 & 245,000 & (c) & $1 / 13 / 2008$ & 21.56 & ${ }^{\mathrm{s} 58,500}$ \\
\hline 9 & 03342000 & Wabash River at Riverton, Ind. & 13,161 & $03 / 1913$ & 26.40 & 250,000 & (c) & 1/17/2008 & 21.21 & ${ }^{\mathrm{d} 55,800}$ \\
\hline 10 & 04097500 & St. Joseph River at Three Rivers, Mich. & 1,350 & 04/1950 & 10.60 & 8,260 & $3 / 49$ & $1 / 12 / 2008$ & 9.44 & 6,330 \\
\hline 11 & 04099000 & St. Joseph River at Mottville, Mich. & 1,866 & 06/1989 & 10.41 & ${ }^{d 11,400}$ & 8/86 & 1/12/2008 & 8.59 & $\mathrm{~d} 8,110$ \\
\hline 12 & 04100222 & North Branch Elkhart River at Cosperville, Ind. & 142 & 03/1982 & 8.12 & d919 & 4/37 & 1/12/2008 & "7.28 & ${ }^{\mathrm{d}} 742$ \\
\hline 13 & 04100500 & Elkhart River at Goshen, Ind. & 594 & 02/1985 & 11.87 & 6,360 & (c) & 1/9/2008 & 10.07 & 4,860 \\
\hline 14 & 04180000 & Cedar Creek near Cedarville, Ind. & 270 & $12 / 1990$ & 13.38 & 5,580 & () & 1/9/2008 & 12.03 & 4,870 \\
\hline 15 & 05515500 & Kankakee River at Davis, Ind. & 537 & 01/2005 & 13.05 & 1,930 & (c) & 1/8/2008 & 13.61 & 1,760 \\
\hline 16 & 05516500 & Yellow River at Plymouth, Ind. & 294 & 10/1954 & 17.13 & 5,390 & 3/60 & 1/10/2008 & 15.13 & 4,010 \\
\hline 17 & 05517000 & Yellow River at Knox, Ind. & 435 & 10/1954 & 13.75 & 5,660 & (c) & $1 / 12 / 2008$ & 12.14 & 4,290 \\
\hline 18 & 05517500 & Kankakee River at Dunns Bridge, Ind. & 1,160 & 03/1982 & 13.38 & 5,870 & (c) & $1 / 13 / 2008$ & 12.69 & 5,230 \\
\hline 19 & 05518000 & Kankakee River at Shelby, Ind. & 1,779 & 03/1982 & 12.98 & 7,650 & (c) & $1 / 12 / 2008$ & 12.43 & 5,660 \\
\hline 20 & 05522500 & Iroquois River at Rensselaer, Ind. & 203 & 07/2003 & 16.59 & 2,620 & (c) & $1 / 10 / 2008$ & 15.06 & 2,290 \\
\hline 21 & 05524500 & Iroquois River near Foresman, Ind. & 449 & 06/1958 & 24.42 & 5,930 & (c) & $1 / 9 / 2008$ & 24.16 & 6,420 \\
\hline 22 & 05527500 & Kankakee River near Wilmington, Ill. & 5,150 & 07/1957 & 11.40 & 75,900 & $7 / 96$ & 1/9/2008 & 8.77 & 49,500 \\
\hline 23 & 05536179 & Hart Ditch at Dyer, Ind. & 37.6 & 11/1990 & 15.33 & 3,010 & (c) & $1 / 8 / 2008$ & 12.31 & 1,660 \\
\hline 24 & 05536195 & Little Calumet River at Munster, Ind. & 90.0 & 04/1959 & 13.67 & 1,510 & 6/50 & 1/9/2008 & 14.58 & 1,050 \\
\hline 25 & 05555300 & Vermilion River near Leonore, IIll. & 1,251 & 07/1958 & 15.30 & 33,500 & 3/78 & 1/9/2008 & 25.22 & 26,900 \\
\hline
\end{tabular}

${ }^{2}$ Rank of the maximum instantaneous peak streamflow measured during January 2008 compared to all systematic and historic annual peaks. A rank of 1

Unless otherwise noted, expected peak streamflows are based on Water Resources Council Bulletin 17B weighting by variance methoo

'The peak streamflow for January 2008 was exceeded by another peak streamflow during 2008.

Streamflow affected to unknown degree by regulation or diversion.

S Streamflow affected by regulation or diversion

Expected peak streamflows are Indiana Coordinated Discharges, which do not include confidence limits (htp://www.state.in.us/dnr/water/4898.htm).

Expected peak streamflows based on Bulletin 17B systematic frequency-curve estimate only.

"A higher stage exists that corresponds to a streamflow that is less than the peak streamflow.

\begin{tabular}{|c|c|c|c|c|c|c|c|c|c|c|c|c|}
\hline \multirow{4}{*}{$\begin{array}{l}\text { Estimated } \\
\text { AEP for } \\
\text { observed } \\
\text { peak } \\
\text { streamflow } \\
\text { (percent) }\end{array}$} & \multicolumn{12}{|c|}{ Expected peak streamflows for selected AEP with 95-percent confidence limits $\left(\mathrm{ft}^{3} \mathrm{~s}\right)^{\mathrm{b}}$} \\
\hline & \multicolumn{3}{|c|}{$\begin{array}{l}\text { 4-percent AEP } \\
\text { (25-year recurrence) }\end{array}$} & \multicolumn{3}{|c|}{$\begin{array}{c}\text { 2-percent AEP } \\
\text { (50-year recurrence) } \\
\end{array}$} & \multicolumn{3}{|c|}{$\begin{array}{c}\text { 1-percent AEP } \\
\text { (100-year recurrence) } \\
\end{array}$} & \multicolumn{3}{|c|}{$\begin{array}{c}\text { 0.2-percent AEP } \\
\text { (500-year recurrence) } \\
\end{array}$} \\
\hline & \multirow{2}{*}{ Estimate } & \multicolumn{2}{|c|}{ Confidence limit } & \multirow{2}{*}{ Estimate } & \multicolumn{2}{|c|}{ Confidence limit } & \multirow{2}{*}{ Estimate } & \multicolumn{2}{|c|}{ Confidence limit } & \multirow{2}{*}{ Estimate } & \multicolumn{2}{|c|}{ Confididnce limit } \\
\hline & & Low & High & & Low & High & & Low & High & & Low & High \\
\hline $4-10$ & 8,220 & 7,210 & 9,370 & 9,170 & 7,840 & 10,700 & 10,100 & 8,440 & 12,200 & 12,400 & 9,670 & 15,900 \\
\hline $4-10$ & 15,500 & 13,500 & 17,700 & 17,400 & 14,800 & 20,500 & 19,400 & 16,000 & 23,500 & 24,200 & 18,600 & 31,300 \\
\hline $4-10$ & 782 & 662 & 925 & 895 & 733 & 1,090 & 1,010 & 804 & 1,280 & 1,310 & 970 & 1,770 \\
\hline $2-4$ & 8,920 & 7,660 & 10,400 & 9,990 & 8,370 & 11,900 & 11,000 & 8,990 & 13,500 & 13,300 & 10,200 & 17,200 \\
\hline$<1$ & 22,200 & -- & -- & 24,600 & -- & -- & 27,100 & -- & -- & -- & -- & -- \\
\hline$>10$ & 96,100 & 86,500 & 107,000 & 110,000 & 96,500 & 125,000 & 124,000 & 106,000 & 144,000 & 158,000 & 128,000 & 195,000 \\
\hline$>10$ & 105,000 & 94,800 & 117,000 & 119,000 & 105,000 & 135,000 & 133,000 & 115,000 & 154,000 & 165,000 & 135,000 & 202,000 \\
\hline$>10$ & 139,000 & 125,000 & 154,000 & 156,000 & 138,000 & 177,000 & 174,000 & 150,000 & 201,000 & 213,000 & 174,000 & 260,000 \\
\hline$>10$ & 134,000 & 121,000 & 149,000 & 152,000 & 134,000 & 172,000 & 169,000 & 146,000 & 196,000 & 208,000 & 171,000 & 254,000 \\
\hline $4-10$ & ${ }^{86} 6,360$ & 5,720 & 7,310 & ${ }^{86,970}$ & 6,200 & 8,140 & ${ }^{87,560}$ & 6,660 & 8,950 & 88,900 & 7,680 & 10,900 \\
\hline $4-10$ & 88,780 & 8,080 & 9,730 & 89,800 & 8,930 & 11,000 & ${ }^{810,800}$ & 9,780 & 12,300 & 813,400 & 11,800 & 15,700 \\
\hline $4-10$ & 873 & 725 & 1,050 & 984 & 793 & 1,220 & 1,100 & 859 & 1,410 & 1,390 & 1,020 & 1,900 \\
\hline $4-10$ & 5,600 & 4,910 & 6,380 & 6,180 & 5,290 & 7,230 & 6,740 & 5,610 & 8,090 & 7,950 & 6,240 & 10,100 \\
\hline $4-10$ & 5,280 & 4,740 & 5,880 & 5,630 & 4,950 & 6,410 & 5,950 & 5,100 & 6,920 & 6,580 & 5,360 & 8,090 \\
\hline $4-10$ & 1,830 & 1,710 & 1,960 & 1,940 & 1,790 & 2,100 & 2,050 & 1,860 & 2,250 & 2,300 & 2,010 & 2,620 \\
\hline $4-10$ & 4,100 & 3,530 & 4,750 & 4,600 & 3,860 & 5,480 & 5,100 & 4,170 & 6,240 & 6,290 & 4,870 & 8,120 \\
\hline $4-10$ & 4,510 & 3,950 & 5,140 & 5,020 & 4,300 & 5,860 & 5,530 & 4,630 & 6,600 & 6,750 & 5,360 & 8,490 \\
\hline $4-10$ & 5,390 & 4,940 & 5,870 & 5,730 & 5,170 & 6,350 & 6,060 & 5,370 & 6,840 & 6,800 & 5,760 & 8,040 \\
\hline$>10$ & 6,370 & 5,940 & 6,830 & 6,730 & 6,180 & 7,320 & 7,060 & 6,390 & 7,810 & 7,760 & 6,740 & 8,930 \\
\hline $4-10$ & 2,360 & 2,160 & 2,580 & 2,570 & 2,310 & 2,860 & 2,770 & 2,450 & 3,140 & 3,250 & 2,740 & 3,860 \\
\hline $1-2$ & 5,690 & 4,930 & 6,550 & 6,300 & 5,340 & 7,430 & 6,880 & 5,690 & 8,320 & 8,210 & 6,430 & 10,500 \\
\hline $4-10$ & 54,700 & 47,300 & 63,300 & 61,300 & 51,600 & 72,900 & 67,500 & 55,200 & 82,600 & 80,800 & 61,300 & 106,000 \\
\hline$>10$ & 83,100 & 2,380 & 4,690 & 83,730 & 2,780 & 5,990 & ${ }^{84,420}$ & 3,200 & 7,540 & ${ }^{86,340}$ & 4,290 & 12,300 \\
\hline $4-10$ & 1,210 & 1,050 & 1,510 & 1,320 & 1,130 & 1,720 & 1,440 & 1,210 & 1,940 & 1,730 & 1,410 & 2,490 \\
\hline 4-10 & 30,700 & 25,600 & 36,900 & 35,000 & 28,300 & 43,400 & 39,100 & 30,500 & 50,200 & 48,200 & 34,400 & 67,500 \\
\hline
\end{tabular}
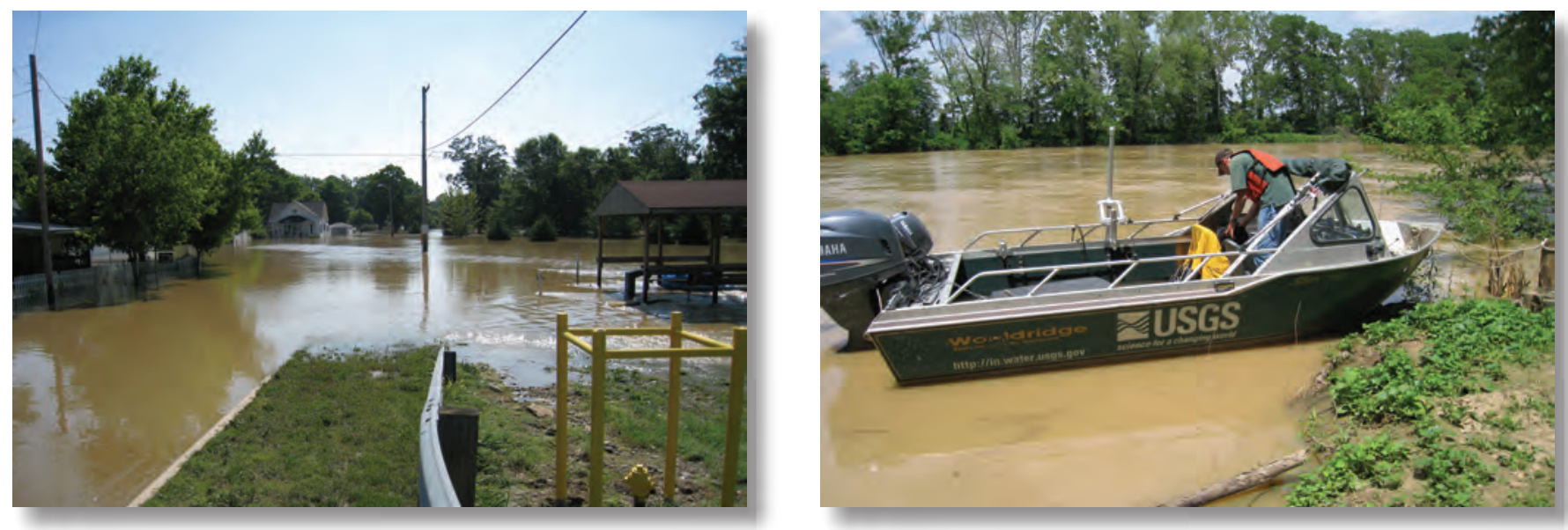

Flooding in Spencer, Indiana from the White River (left) and USGS personnel launching boat (right) to make a streamflow 
Table 2. Summary of peak stages, streamflows, and flood-probability estimates for selected U.S. Geological Survey streamgages during February 2008.

[mi², square mile; ft, foot; fris/s, cubic foot per second; AEP, annual exceedance probability; >, greater than; --, no data]

\begin{tabular}{|c|c|c|c|c|c|c|c|c|c|c|}
\hline \multirow{3}{*}{$\begin{array}{c}\text { Site } \\
\text { number } \\
\text { (fig. 8) }\end{array}$} & \multirow{3}{*}{$\begin{array}{l}\text { Station } \\
\text { number }\end{array}$} & \multirow{3}{*}{ Station name } & \multirow{3}{*}{$\begin{array}{c}\text { Contributing } \\
\text { drainage } \\
\text { area } \\
\left(\mathbf{m i}^{2}\right)\end{array}$} & \multicolumn{7}{|c|}{ Flood data } \\
\hline & & & & \multicolumn{3}{|c|}{ Previous maximum streamflow } & \multicolumn{4}{|c|}{ Flood of February 2008} \\
\hline & & & & Date & $\begin{array}{c}\text { Stage } \\
(\mathrm{ft})\end{array}$ & $\begin{array}{c}\text { Streamflow } \\
\left(\mathrm{t}^{3} / \mathrm{s}\right)\end{array}$ & $\begin{array}{l}\text { Ranka/ } \\
\text { annual } \\
\text { peaks }\end{array}$ & Date & $\begin{array}{l}\begin{array}{l}\text { Peak } \\
\text { stage } \\
\text { (ft) }\end{array}\end{array}$ & $\begin{array}{l}\text { Peak } \\
\text { streamflow } \\
\left(\mathrm{ft}^{2} / \mathrm{s}\right)\end{array}$ \\
\hline 1 & 03322900 & Wabash River at Linn Grove, Ind. & 453 & $07 / 2003$ & 14.76 & ${ }^{\circ} 14,500$ & $2 / 45$ & $2 / 7 / 2008$ & 13.52 & 99,890 \\
\hline 2 & 03324000 & Little River near Huntington, Ind. & 263 & $01 / 1950$ & 16.90 & 5,990 & $5 / 65$ & $2 / 7 / 2008$ & 18.91 & 5,180 \\
\hline 3 & 03325000 & Wabash River at Wabash, Ind. & 1,768 & $03 / 1913$ & 28.70 & 90,000 & $44 / 86$ & $2 / 6 / 2008$ & 16.37 & ${ }^{d} 14,400$ \\
\hline 4 & 03327500 & Wabash River at Peru, Ind. & 2,686 & $03 / 1913$ & 28.10 & 115,000 & $39 / 67$ & 2/6/2008 & 12.39 & ${ }^{\mathrm{d}} 15,800$ \\
\hline 5 & 03328000 & Eel River at North Manchester, Ind. & 417 & $12 / 1990$ & 20.16 & 8,740 & 3/87 & 2/6/2008 & 14.09 & 8,230 \\
\hline 6 & 03328500 & Eel River near Logansport, Ind. & 789 & $02 / 1985$ & 12.68 & 17,700 & 6/66 & $2 / 7 / 2008$ & 11.31 & 13,500 \\
\hline 7 & 03329000 & Wabash River at Logansport, Ind. & 3,779 & $03 / 1913$ & 25.30 & 140,000 & $41 / 94$ & $2 / 6 / 2008$ & 12.70 & ${ }^{c} 32,400$ \\
\hline 8 & 03330500 & Tippecanoe River at Oswego, Ind. & 113 & $03 / 1982$ & 9.25 & ${ }^{c} 950$ & $6 / 60$ & 2/10/2008 & 8.54 & ${ }^{\circ} 661$ \\
\hline 9 & 03331500 & Tippecanoe River near Ora, Ind. & 856 & $06 / 1981$ & 15.08 & 8,660 & () & $2 / 8 / 2008$ & 15.60 & 9,200 \\
\hline 10 & 03333050 & Tippecanoe River near Delphi, Ind. & 1,869 & $12 / 1990$ & 12.87 & 22,100 & () & $2 / 6 / 2008$ & 14.89 & ${ }_{2} 24,600$ \\
\hline 11 & 03335500 & Wabash River at Lafayette, Ind. & 7,267 & $03 / 1913$ & 32.90 & 190,000 & $15 / 105$ & 2/7/2008 & 23.94 & ${ }^{\circ} 72,400$ \\
\hline 12 & 03336000 & Wabash River at Covington, Ind. & 8,218 & $03 / 1913$ & 35.10 & 200,000 & $15 / 82$ & 2/8/2008 & 27.67 & ${ }^{\circ} 74,000$ \\
\hline 13 & 03336645 & Middle Fork Vermilion River, Oakwood, IIl. & 432 & $04 / 1994$ & 20.46 & 15,500 & $4 / 32$ & $2 / 6 / 2008$ & 16.16 & 12,600 \\
\hline 14 & 03336900 & Salt Fork near St. Joseph, Ill. & 134 & $05 / 1968$ & 18.26 & 6,860 & $4 / 38$ & $2 / 6 / 2008$ & 19.06 & 5,660 \\
\hline 15 & 03341500 & Wabash River at Terre Haute, Ind. & 12,263 & $03 / 1913$ & 31.20 & 245,000 & ()$^{()}$ & 2/10/2008 & 25.00 & ${ }^{c 92,200}$ \\
\hline 16 & 03342000 & Wabash River at Riverton, Ind. & 13,161 & $03 / 1913$ & 26.40 & 250,000 & (') & 2/12/2008 & 24.16 & 977,300 \\
\hline 17 & 03374000 & White River at Petersburg, Ind. & 11,125 & $03 / 1913$ & 29.50 & 235,000 & (') & 2/13/2008 & 23.58 & ${ }^{7} 70,600$ \\
\hline 18 & 04100222 & North Branch Elkhart River at Cosperville, Ind. & 142 & $03 / 1982$ & 8.12 & ${ }^{9919}$ & () & $2 / 11 / 2008$ & 7.58 & ${ }^{\circ} 718$ \\
\hline 19 & 04100500 & Elkhart River at Goshen, Ind. & 594 & $02 / 1985$ & 11.87 & 6,360 & $8 / 81$ & 2/6/2008 & 10.39 & 5,080 \\
\hline 20 & 04180000 & Cedar Creek near Cedarville, Ind. & 270 & $12 / 1990$ & 13.38 & 5,580 & 3/62 & 2/7/2008 & 12.83 & 5,290 \\
\hline 21 & 05515500 & Kankakee River at Davis, Ind. & 537 & $01 / 2005$ & 13.05 & 1,930 & $($ () & $2 / 6 / 2008$ & ${ }^{8} 13.17$ & 1,580 \\
\hline 22 & 05516500 & Yellow River at Plymouth, Ind. & 294 & $10 / 1954$ & 17.13 & 5,390 & () & $2 / 7 / 2008$ & 14.94 & 3,590 \\
\hline 23 & 05517000 & Yellow River at Knox, Ind. & 435 & 10/1954 & 13.75 & 5,660 & $3 / 65$ & 2/9/2008 & 12.16 & 4,310 \\
\hline 24 & 05517500 & Kankakee River at Dunns Bridge, Ind. & 1,160 & $03 / 1982$ & 13.38 & 5,870 & $2 / 60$ & 2/12/2008 & ${ }^{8} 12.72$ & 5,420 \\
\hline 25 & 05518000 & Kankakee River at Shelby, Ind. & 1,779 & $03 / 1982$ & 12.98 & 7,650 & () & $2 / 13 / 2008$ & 12.27 & 5,710 \\
\hline 26 & 05522500 & Iroquois River at Rensselaer, Ind. & 203 & $07 / 2003$ & 16.59 & 2,620 & $4 / 61$ & $2 / 7 / 2008$ & 15.64 & 2,490 \\
\hline 27 & 05524500 & Iroquois River near Foresman, Ind. & 449 & $06 / 1958$ & 24.42 & 5,930 & $1 / 60$ & 2/7/2008 & 822.70 & 6,480 \\
\hline
\end{tabular}

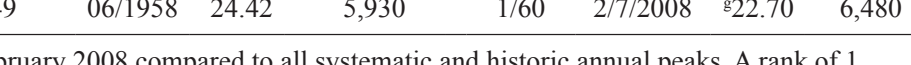

in Rank of the maximum instantaneous peak streamflow measured during February 2008 compare
indicates that the February 2008 peak streamflow was higher than all other recorded annual peaks.

${ }^{b}$ Unless otherwise noted, expected peak streamflows are based on Water Resources Council Bulletin 17B weighting by variance method.

Streamflow affected to unknown degree by regulation or diversion.

"Streamflow affected by regulation or diversion.

"Expected peak streamflows are Indiana Coordinated Discharges, which do not include confidence limits (http://wwwstate in .us/dnrrwater/4898. htm).

The peak streamflow for February 2008 was exceeded by another peak streamflow during 2008.

"A higher stage exists that corresponds to a streamflow that is less than the peak streamflow.

\begin{tabular}{|c|c|c|c|c|c|c|c|c|c|c|c|c|}
\hline \multirow{4}{*}{$\begin{array}{l}\text { Estimated } \\
\text { AEP for } \\
\text { observed } \\
\text { peak } \\
\text { streamflow } \\
\text { (percent) }\end{array}$} & \multicolumn{12}{|c|}{ Expected peak streamflows for selected AEP with 95-percent confidence limits $\left(\mathrm{ft}^{3} \mathrm{~s}\right)^{\mathrm{b}}$} \\
\hline & \multicolumn{3}{|c|}{$\begin{array}{l}\text { 4-percent AEP } \\
\text { (25-year recurrence) }\end{array}$} & \multicolumn{3}{|c|}{$\begin{array}{c}\text { 2-percent AEP } \\
\text { (50-year recurrence) } \\
\end{array}$} & \multicolumn{3}{|c|}{$\begin{array}{c}\text { 1-percent AEP } \\
\text { (100-year recurrence) } \\
\end{array}$} & \multicolumn{3}{|c|}{$\begin{array}{c}\text { 0.2-percent AEP } \\
\text { (500-year recurrence) } \\
\end{array}$} \\
\hline & \multirow{2}{*}{ Estimate } & \multicolumn{2}{|c|}{ Confidence limit } & \multirow{2}{*}{ Estimate } & \multicolumn{2}{|c|}{ Confidence limit } & \multirow{2}{*}{ Estimate } & \multicolumn{2}{|c|}{ Confidence limit } & \multirow[b]{2}{*}{ Estimate } & \multicolumn{2}{|c|}{ Confidence limit } \\
\hline & & Low & High & & Low & High & & Low & High & & Low & High \\
\hline $4-10$ & 10,100 & 8,610 & 12,000 & 11,000 & 9,100 & 13,400 & 11,800 & 9,440 & 14,700 & 13,200 & 9,940 & 17,500 \\
\hline $4-10$ & 5,530 & 5,010 & 6,090 & 5,940 & 5,290 & 6,670 & 6,340 & 5,540 & 7,260 & 7,250 & 6,040 & 8,700 \\
\hline$>10$ & e22,500 & -- & -- & 25,500 & -- & -- & 29,500 & -- & -- & -- & -- & -- \\
\hline$>10$ & ${ }^{2} 23,900$ & -- & -- & 26,900 & -- & -- & ${ }^{\circ} 30,900$ & -- & -- & -- & -- & -- \\
\hline $2-4$ & 8,220 & 7,210 & 9,370 & 9,170 & 7,840 & 10,700 & 10,100 & 8,440 & 12,200 & 12,400 & 9,670 & 15,900 \\
\hline $4-10$ & 15,500 & 13,500 & 17,700 & 17,400 & 14,800 & 20,500 & 19,400 & 16,000 & 23,500 & 24,200 & 18,600 & 31,300 \\
\hline$>10$ & 68,400 & 59,600 & 78,500 & 80,300 & 67,700 & 95,300 & 92,800 & 75,700 & 114,000 & 125,000 & 94,100 & 166,000 \\
\hline $4-10$ & 782 & 662 & 925 & 895 & 733 & 1,090 & 1,010 & 804 & 1,280 & 1,310 & 970 & 1,770 \\
\hline $2-4$ & 8,920 & 7,660 & 10,400 & 9,990 & 8,370 & 11,900 & 11,000 & 8,990 & 13,500 & 13,300 & 10,200 & 17,200 \\
\hline $1-2$ & 22,200 & -- & -- & '24,600 & -- & -- & $\cdot 27,100$ & -- & -- & -- & -- & -- \\
\hline$>10$ & 96,100 & 86,500 & 107,000 & 110,000 & 96,500 & 125,000 & 124,000 & 106,000 & 144,000 & 158,000 & 128,000 & 195,000 \\
\hline$>10$ & 105,000 & 94,800 & 117,000 & 119,000 & 105,000 & 135,000 & 133,000 & 115,000 & 154,000 & 165,000 & 135,000 & 202,000 \\
\hline $4-10$ & 14,800 & 12,200 & 18,000 & 17,300 & 13,700 & 21,800 & 19,900 & 15,200 & 26,100 & 26,500 & 18,500 & 37,900 \\
\hline $4-10$ & 6,280 & 4,830 & 8,150 & 7,390 & 5,460 & 10,000 & 8,580 & 6,070 & 12,100 & 11,600 & 7,430 & 18,200 \\
\hline$>10$ & 139,000 & 125,000 & 154,000 & 156,000 & 138,000 & 177,000 & 174,000 & 150,000 & 201,000 & 213,000 & 174,000 & 260,000 \\
\hline$>10$ & 134,000 & 121,000 & 149,000 & 152,000 & 134,000 & 172,000 & 169,000 & 146,000 & 196,000 & 208,000 & 171,000 & 254,000 \\
\hline$>10$ & 153,000 & 139,000 & 170,000 & 173,000 & 153,000 & 195,000 & 191,000 & 166,000 & 221,000 & 235,000 & 192,000 & 286,000 \\
\hline$>10$ & 873 & 725 & 1,050 & 984 & 793 & 1,220 & 1,100 & 859 & 1,410 & 1,390 & 1,020 & 1,900 \\
\hline 4-10 & 5,600 & 4,910 & 6,380 & 6,180 & 5,290 & 7,230 & 6,740 & 5,610 & 8,090 & 7,950 & 6,240 & 10,100 \\
\hline $2-4$ & 5,280 & 4,740 & 5,880 & 5,630 & 4,950 & 6,410 & 5,950 & 5,100 & 6,920 & 6,580 & 5,360 & 8,090 \\
\hline$>10$ & 1,830 & 1,710 & 1,960 & 1,940 & 1,790 & 2,100 & 2,050 & 1,860 & 2,250 & 2,300 & 2,010 & 2,620 \\
\hline $4-10$ & 4,100 & 3,530 & 4,750 & 4,600 & 3,860 & 5,480 & 5,100 & 4,170 & 6,240 & 6,290 & 4,870 & 8,120 \\
\hline $4-10$ & 4,510 & 3,950 & 5,140 & 5,020 & 4,300 & 5,860 & 5,530 & 4,630 & 6,600 & 6,750 & 5,360 & 8,490 \\
\hline $2-4$ & 5,390 & 4,940 & 5,870 & 5,730 & 5,170 & 6,350 & 6,060 & 5,370 & 6,840 & 6,800 & 5,760 & 8,040 \\
\hline$>10$ & 6,370 & 5,940 & 6,830 & 6,730 & 6,180 & 7,320 & 7,060 & 6,390 & 7,810 & 7,760 & 6,740 & 8,930 \\
\hline $2-4$ & 2,360 & 2,160 & 2,580 & 2,570 & 2,310 & 2,860 & 2,770 & 2,450 & 3,140 & 3,250 & 2,740 & 3,860 \\
\hline $1-2$ & 5,690 & 4,930 & 6,550 & 6,300 & 5,340 & 7,430 & 6,880 & 5,690 & 8,320 & 8,210 & 6,430 & 10,500 \\
\hline
\end{tabular}

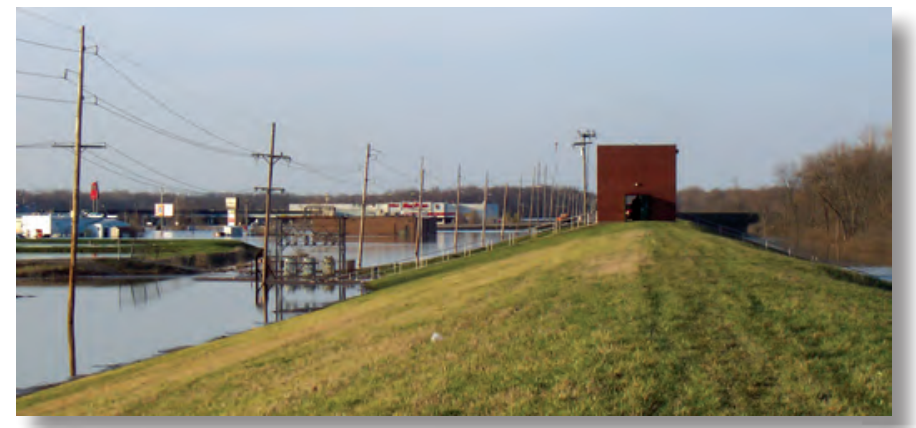

Flooding in Harrisburg, Illinois. Flooding was because of local drainage interior to the levee (foreground) that could not be evacuated quick enough by the pumping station located in the b
structure atop the levee. Photograph by Robert Holmes, USGS.

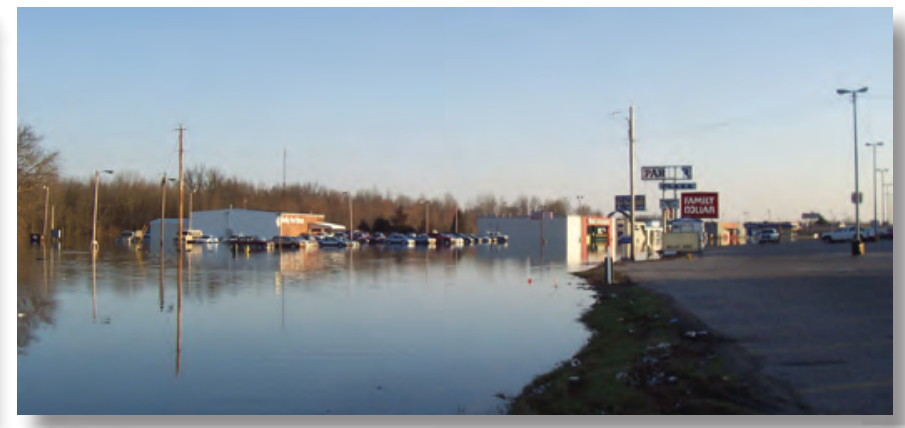

Flooding in Harrisburg, Illinois. Photograph by Robert Holmes, USGS. 
Table 3. Summary of peak stages, streamflows, and flood-probability estimates for selected U.S. Geological Survey streamgages during March 2008.

[mi², square mile; ft, foot; ft³/s, cubic foot per second; AEP, annual exceedance probability; $>$, greater than; $<$ less than; --, no data]

\section{Site
number Station}

Station name

\section{Contributing
drainage Previous maximum streamflow \\ area \\ Date $\underset{\substack{\text { Stage } \\(\mathrm{tt})}}{\substack{\text { Streamflow } \\(\mathrm{t} \mathrm{t} / \mathrm{s})}}$}

03302800 Blue River at Fredricksburg, Ind.

203303000 Blue River near White Cloud, Ind

$\begin{array}{lll}4 & 03366500 & \text { Museth }\end{array}$

503376500 Patoka River near Princeton, Ind.

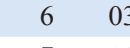

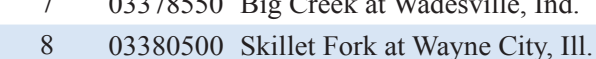

93382100 South Fork Saline River near Carrier Mills, III.

$10 \quad 03384450$ Lusk Creek near Eddyville, III.

$\begin{array}{lll}11 & 05592900 \text { East Fork Kaskaskia River near Sandoval, Ill } \\ 12 & 05593575 \text { Crooked Creek near New Minden, III }\end{array}$

1205593575 Crooked Creek near New Minden, III.

1405595200 Richland Creek near Hecker, Ill.

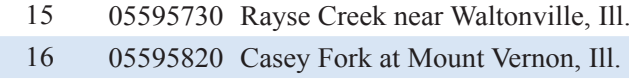

1705597500 Crab Orchard Creek near Marion, IIl.

$\begin{array}{lllll}2,159 & 05 / 1996 & 37.65 & 33,800\end{array}$

2006918440 Sac River near Dadeville, Mo.

70 Pon Rer near Dadeville, Mo.

$\begin{array}{lllll} & 01 / 2005 & 16.33 & 28,800\end{array}$

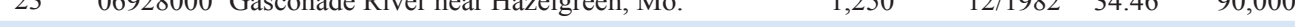

2406928300 Roubidoux Creek above Fort Wood, Mo.

$26-0693430$ Roubidoux Creek below Fort Wood,

27.0930000 Big Piney River near Big Piney, $\mathrm{M}$.

2806933500 Gasconade River at Jerome, Mo.

2906934000 Gasconade River near Rich Fountain, $\mathrm{M}$.
30
07013000 Meramec River near Steelville, Mo.

$31 \quad 07014500$ Meramec River near Sullivan, $\mathrm{M}$.

320701600 Bourbeuse River at Union, $\mathrm{M}$

$34 \quad 07018500$ Big River at Byrnesville, Mo.

3507019000 Meramec River near Eureka,

3607021000 Castor River at Zalma, Mo.

$\begin{array}{lll}37 & 07035800 & \text { St. Francis River near Mill Creek, } \\ 38 & 07036100 & \text { St. Francis }\end{array}$

390703750 St. Francis River near Saco, Mo.

$40 \quad 07043500$ Little River Ditch No.1 near Morehouse, Mo.

$41 \quad 07050700$

$\begin{array}{ll}41 & 07050700 \text { James River near Springfield, } \\ 42 & 07052250 \text { James River near Boaz, Mo }\end{array}$

4407053810 Bull Creek near Walnut Shade, Mo.

4507054080 Beaver Creek at Bradleyville, Mo.

$\begin{array}{llll}165 & 05 / 2002 & 14.86 & 12,900\end{array}$

$\begin{array}{llll}287 & 05 / 2002 & 14.13 & 14,000\end{array}$

$\begin{array}{llll}560 & 12 / 1982 & 24.50 & 81,200\end{array}$ $\begin{array}{lll}05 / 2002 & 18.89 & 43,400\end{array}$ $\begin{array}{llll}2,840 & 12 / 1982 & 31.34 & 136,000 \\ 3,180 & 12 / 1982 & 33.27 & 134,000\end{array}$ $\begin{array}{rrrr}781 & 08 / 1915 & 26.50 & 60,000\end{array}$ $\begin{array}{llll}1,475 & 08 / 1915 & 33.50 & 90,000\end{array}$ $\begin{array}{llll}808 & 12 / 1982 & 33.80 & 73,300\end{array}$ $\begin{array}{lll}08 / 1915 & 30.20 & 80,000\end{array}$ $\begin{array}{llll}3.788 & 08 / 1915 & 40.20 & 175,000\end{array}$ $\begin{array}{llll}423 & 12 / 1982 & 29.92 & \text { d97,100 }\end{array}$ $\begin{array}{llll}505 & 11 / 1993 & 33.10 & 130,000\end{array}$ $\begin{array}{llll}664 & 11 / 1993 & 36.10 & 161,000\end{array}$ $\begin{array}{llll}956 & 12 / 1982 & 35.77 & 155,000\end{array}$ $\begin{array}{llll}450 & 02 / 1989 & 19.30 & 12,000\end{array}$ $\begin{array}{llll}446 & 07 / 1909 & 22.00 & 62,000 \\ 462 & 071973 & 20.56 & 31,00\end{array}$ $\begin{array}{llll}462 & 07 / 1973 & 20.56 & 31,400\end{array}$ $\begin{array}{llll}987 & 09 / 1993 & 33.46 & 73,200 \\ 191 & 05 / 2002 & 14.41 & 32,200\end{array}$

4607056000 Buffalo River near St. Joe, Ark.

\section{Flood of March 2008}

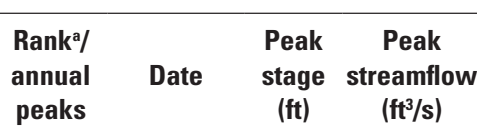
\begin{tabular}{lll} 
peaks & $(\mathrm{ft})$ & $\left(\mathrm{tt}^{3} / \mathrm{s}\right)$ \\
\hline
\end{tabular} $\begin{array}{llll}1 / 40 & 3 / 19 / 2008 & 27.37 & 41,700 \\ 1 / 83 & 3 / 202008 & 2.15 & 31,00\end{array}$ $\begin{array}{llll}\text { (c) } 3 / 22 / 2008 & 19.99 & 847,100\end{array}$ $\begin{array}{llll}2 / 61 & 3 / 492008 & 30.51 & 36,600\end{array}$ $\begin{array}{llll}6 / 68 & 3 / 20 / 2008 & 23.27 & 5,530\end{array}$ $\begin{array}{llll}1443 & 31192008 & 20.55 \quad 14300\end{array}$ $\begin{array}{lllll}6 / 91 & 3 / 20 / 2008 & 23.29 & 22,900\end{array}$

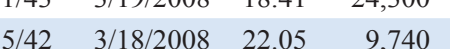
$\begin{array}{llll}4 / 29 & 3 / 19 / 2008 & 20.06 & 9,300 \\ 5 / 41 & 3 / 19 / 2008 & 21.22 & 9,950\end{array}$ $\begin{array}{lllll}8 / 39 & 3 / 21 / 2008 & 24.01 & 9,950\end{array}$ $\begin{array}{llll}4 / 39 & 3 / 19 / 2008 & 42.90 & 13,200\end{array}$ $\begin{array}{llll}7 / 29 & 3 / 19 / 2008 & 16.09 & 13,700 \\ 4 / 23 & 3 / 192008 & 16.09 & 10,300\end{array}$ $\begin{array}{lllll}1 / 57 & 3 / 19 / 2008 & 13.74 & 10,000\end{array}$ $\begin{array}{llll}4 / 80 & 3 / 22 / 2008 & 37.24 & 31,500\end{array}$ $\begin{array}{lllll}1 / 67 & 3 / 19 / 2008 & 15.74 & 31,500 \\ 3 / 44 & 3 / 19 / 2008 & 21.32 & 14,600\end{array}$ $\begin{array}{llll}1 / 13 & 3 / 19 / 2008 & 17.06 & 32,600\end{array}$ $\begin{array}{llll}64 & 3 / 19 / 2008 & 34.92 & 89,500\end{array}$ (c) $3 / 1912008 \quad 19.92 \quad 24,500$ $\begin{array}{llll}1 / 8 & 3 / 19 / 2008 & 18.45 & 28,900\end{array}$ $\begin{array}{llll}2 / 79 & 3 / 19 / 2008 & 23.58 & 64,000\end{array}$ $\begin{array}{llll}3 / 8 & 3 / 19 / 2008 & 23.45 & 66,000\end{array}$

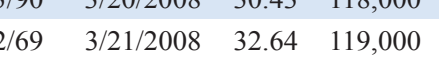
$\begin{array}{lllll}4 / 93 & 3 / 19 / 2008 & 26.84 & 52,700\end{array}$ $\begin{array}{llll}4 / 78 & 3 / 20 / 2008 & 31.69 & 66,900\end{array}$ $\begin{array}{lll}3 / 19 / 2008 & 28.70 & 52,800\end{array}$ $\begin{array}{llll}487 & 3202008 & 27.57 & 47,300\end{array}$ $\begin{array}{lllll}1 / 80 & 3 / 19 / 2008 & 30.47 & \mathrm{~d} 114,000\end{array}$ $\begin{array}{llll}3 / 20 & 3 / 19 / 2008 & 23.61 & 50,500\end{array}$ $\begin{array}{llll}2 / 17 & 3 / 19 / 2008 & 28.93 & 69,000\end{array}$ $\begin{array}{llll}3 / 87 & 3 / 19 / 2008 & 30.82 & 79,300 \\ 6 / 60 & 3 / 19 / 2008 & 18.66 & 10,100\end{array}$ $\begin{array}{llll}3 / 54 & 3 / 18 / 2008 & 19.32 & 34,200 \\ 1 / 15 & 31192008 & 23.55 & 41900\end{array}$ $\begin{array}{llll}3 / 19 / 2008 & 23.55 & 41,900\end{array}$ $\begin{array}{cccc}1 / 87 & 3 / 19 / 2008 & 35.96 & 85,100 \\ \text { (c) } & 3 / 18 / 2008 & 16.00 & 24,700\end{array}$ $\begin{array}{llll}1 / 14 & 3 / 19 / 2008 & 19.03 & 33,200 \\ 3 / 81 & 3 / 19 / 2008 & 49.41 & 134,000\end{array}$

\begin{tabular}{|c|c|c|c|c|c|c|c|c|c|c|c|c|}
\hline \multirow{4}{*}{$\begin{array}{l}\text { Estimated } \\
\text { AEP for } \\
\text { observed } \\
\text { peak } \\
\text { streamflow } \\
\text { (percent) }\end{array}$} & \multicolumn{12}{|c|}{ Expected peak streamflows for selected AEP with 95-percent confidence limits $\left(\mathrm{ft}^{2} / \mathrm{s}^{\mathrm{b}}\right.$} \\
\hline & \multicolumn{3}{|c|}{$\begin{array}{l}\text { 4-percent AEP } \\
\text { (25-year recurrence) }\end{array}$} & \multicolumn{3}{|c|}{$\begin{array}{l}\text { 2-percent AEP } \\
\text { (50-year recurrence) }\end{array}$} & \multicolumn{3}{|c|}{$\begin{array}{c}\text { 1-percent AEP } \\
\text { (100-year recurrence) }\end{array}$} & \multicolumn{3}{|c|}{$\begin{array}{c}\text { 0.2-percent AEP } \\
\text { (500-year recurrence) }\end{array}$} \\
\hline & \multirow{2}{*}{ Estimate } & \multicolumn{2}{|c|}{ Confidence limit } & \multirow{2}{*}{ Estimate } & \multicolumn{2}{|c|}{ Confidence limit } & \multirow{2}{*}{ Estimate } & \multicolumn{2}{|c|}{ Confidence limit } & \multirow{2}{*}{ Estimate } & \multicolumn{2}{|c|}{ Confidence limit } \\
\hline & & Low & High & & Low & High & & Low & High & & Low & High \\
\hline $0.2-1$ & 24,100 & 19,200 & 30,200 & 28,300 & 22,100 & 36,300 & 32,700 & 25,000 & 42,900 & 44,400 & 31,600 & 62,200 \\
\hline $1-2$ & 27,300 & 23,700 & 31,500 & 31,000 & 26,300 & 36,600 & 34,900 & 28,800 & 42,200 & 44,700 & 34,700 & 57,500 \\
\hline$>10$ & 134,000 & 121,000 & 149,000 & 152,000 & 134,000 & 172,000 & 169,000 & 146,000 & 196,000 & 208,000 & 171,000 & 254,000 \\
\hline $.2-1$ & 29,600 & 26,600 & 33,000 & 32,800 & 28,900 & 37,200 & 35,700 & 30,900 & 41,300 & 42,300 & 35,000 & 51,100 \\
\hline $4-10$ & 813,800 & 11,200 & 18,400 & 815,800 & 12,700 & 21,800 & ${ }^{8} 17,900$ & 14,100 & 25,300 & 822,800 & 17,300 & 34,200 \\
\hline $4-10$ & 6,600 & 5,640 & 7,740 & 7,480 & 6,210 & 9,010 & 8,370 & 6,750 & 10,400 & 10,500 & 7,880 & 14,100 \\
\hline$<.2$ & 8,940 & 7,330 & 10,900 & 9,730 & 7,730 & 12,200 & 10,500 & 8,070 & 13,600 & 12,100 & 8,650 & 16,900 \\
\hline $4-10$ & 29,800 & 23,200 & 38,300 & 36,700 & 27,300 & 49,200 & 43,900 & 31,200 & 61,800 & 62,300 & 39,600 & 98,000 \\
\hline$<.2$ & 7,780 & 5,7 & 10,5 & 9,450 & 6,660 & 13,400 & 11,300 & 7,550 & 16,8 & 00 & 9,610 & 27,300 \\
\hline $4-10$ & 11,900 & 9,370 & 15,100 & 13,600 & 10,400 & 17,900 & 15,400 & 11,300 & 21,100 & 19,700 & 13,100 & 29,500 \\
\hline $4-10$ & 11,500 & 8,170 & 16,300 & 13,700 & 9,290 & 20,300 & 16,000 & 10,300 & 24,900 & 21,600 & 12,500 & 37,500 \\
\hline 4-10 & 11,6 & & 15,5 & 13 & & 19,1 & 5,800 & 900 & 23,0 & 0 & 12,800 & 3,600 \\
\hline$>10$ & 854,800 & 44,600 & 72,300 & 862,600 & 50,100 & 84,700 & 870,200 & 55,400 & 97,100 & 887,200 & 66,900 & 126,000 \\
\hline $4-10$ & 14,600 & 11,100 & 19,200 & 17,100 & 12,400 & 23,500 & 19,700 & 13,700 & 28,200 & 25,900 & 16,300 & 41,200 \\
\hline$>10$ & & 12,6 & & & & 38,7 & & & & & &, 100 \\
\hline 4-10 & 13,600 & 8,990 & 20,500 & 16,200 & 10,200 & 25,700 & 18,800 & 11,200 & 31,400 & 25,100 & 13,300 & 7,200 \\
\hline $.2-1$ & 6,480 & 4,690 & 8,940 & 8,050 & 5,530 & 11,700 & 9,740 & 6,350 & 14,900 & 14,100 & 8,110 & 24,400 \\
\hline $4-10$ & 832,6 & & & & & & & & & & & \\
\hline $.2-1$ & 4,240 & 3,530 & 5,090 & 4,920 & 3,950 & 6,140 & 5,660 & 4,360 & 7,350 & 7,650 & 5,360 & 10,900 \\
\hline $4-10$ & 20,100 & 14,300 & 28,300 & 25,700 & 17,600 & 37,700 & 31,900 & 21,000 & 48,400 & 46,900 & 28,900 & 76,200 \\
\hline $4-10$ & & 22,10 & 31,30 & & 23,70 & 35,70 & & 25,200 & $40,30 c$ & & 28,500 & 52,600 \\
\hline $4-10$ & 40,100 & -- & -- & 47,300 & -- & -- & 55,100 & -- & - & 73,500 & -- & - \\
\hline $2-4$ & 79,700 & 64,000 & 99,300 & 94,900 & 73,400 & 123,000 & 110,000 & 81,800 & 147,000 & 144,000 & 98,900 & 209,000 \\
\hline $2-4$ & & -- & -- & & -- & -- & & - & -- & & -- & -- \\
\hline $2-4$ & i26,900 & -- & -- & i31,900 & -- & -- & 37,200 & -- & -- & is 50,000 & -- & -- \\
\hline .2-1 & & 33,200 & 51,800 & 50,200 & 38,700 & 65,000 & & 44,200 & 79,800 & & 56,500 & 119,000 \\
\hline $.2-$ & & -- & -- & & -- & -- & & & -- & & -- & -- \\
\hline $1-2$ & 97,900 & 81,900 & 117,000 & 116,000 & 93,800 & 143,000 & 135,000 & 105,000 & 173,000 & 181,000 & 131,000 & 251,000 \\
\hline $1-2$ & 94,900 & 77,700 & 116,000 & 114,000 & 89,800 & 144,000 & 134,000 & 102,000 & 175,000 & 184,000 & 130,000 & 260,000 \\
\hline $2-4$ & & 40, & & & & 75,1 & & & & & 61,600 & 130,000 \\
\hline 4-10 & 74,90 & 56,6 & & 89 & 63,500 & 125,000 & 104,000 & 70,800 & 152,000 & 138,000 & 87,500 & 218,000 \\
\hline $4-10$ & & 32,2 & & & & & & & & & 53,000 & 99,500 \\
\hline $2-4$ & 52,3 & 37, & 72,0 & 60,80 & 42,600 & 86,7 & 0 & 47,100 & 102,000 & , 800 & 57,000 & 142,000 \\
\hline $2-4$ & 46, & 38,7 & & & & & & 200 & 81, & & 60,500 & 116,000 \\
\hline $2-$ & 114,0 & & 136,0 & 136, & 110 & 167, & 159, & 125,000 & & & 160,000 & 300,000 \\
\hline$<.2$ & 50,9 & 37,6 & 68,7 & 63,90 & 45,300 & 90,1 & 77,100 & 52,600 & 113,000 & 07,000 & 67,900 & 170,000 \\
\hline$>1$ & $67, \mathrm{C}$ & 45,8 & & & & & & & & & 70,300 & , 000 \\
\hline 4-10 & & & & & & & & & & & 87,500 & 224,000 \\
\hline 4-10 & 84,7 & 70,600 & 102,000 & 98,300 & 79,400 & 122,000 & 112,000 & 87,700 & 144,000 & 146,000 & 106,000 & 202,000 \\
\hline 4-10 & & & & & 10,2 & & 13,000 & 800 & 15,600 & 15,300 & 11,800 & 19,700 \\
\hline $2-4$ & & & & & & & & & & & 38,300 & \\
\hline $2-4$ & & & & 44,11 & 32,800 & 59,1 & 50,200 & 35,700 & 70,600 & 65,900 & 42,900 & 101,000 \\
\hline & & 46,2 & & & 52,5 & & 75800 & & 97,900 & 101,000 & 72,200 & \\
\hline 4-10 & 33,000 & & & & & & & & 75,700 & 62,900 & 36,900 & \\
\hline $4-10$ & 34,200 & 22,600 & 51,800 & 40,800 & 26,200 & 63,500 & 47,600 & 29,900 & 75,800 & 64,200 & 38,300 & 107,000 \\
\hline & & & & & & & & & & & & \\
\hline
\end{tabular}


Table 3. Summary of peak stages, streamflows, and flood-probability estimates for selected U.S. Geological Survey streamgages during March 2008.-Continued

[mi², square mile; ft, foot; ff's/s, cubic foot per second; AEP, annual exceedance probability; $>$, greater than; $<$, less than; --, no data]

\begin{tabular}{|c|c|c|c|c|c|c|c|c|c|}
\hline \multirow{3}{*}{$\begin{array}{c}\text { Site } \\
\text { number } \\
\text { (fig. 10) }\end{array}$} & \multirow{3}{*}{ Station name } & \multirow{3}{*}{$\begin{array}{l}\text { Contributing } \\
\text { drainage } \\
\text { area } \\
\left(\mathrm{mi}^{2}\right)\end{array}$} & \multicolumn{7}{|c|}{ Flood data } \\
\hline & & & \multicolumn{3}{|c|}{ Previous maximum streamflow } & \multicolumn{4}{|c|}{ Flood of March 2008} \\
\hline & & & Date & $\begin{array}{c}\text { Stage } \\
\text { (ftre }\end{array}$ & $\begin{array}{c}\text { Streamflow } \\
\left(\mathrm{ft}^{\mathrm{t}} / \mathrm{s}\right)\end{array}$ & $\begin{array}{l}\text { Ranka/ } \\
\text { annual } \\
\text { peaks }\end{array}$ & Date & $\begin{array}{l}\text { Peak } \\
\text { stage } \\
\text { (tt) }\end{array}$ & $\begin{array}{c}\text { Peak } \\
\text { streanfllow } \\
\left(\mathbf{t}^{2} / \mathbf{s}\right)\end{array}$ \\
\hline 47 & 07057500 North Fork River near Tecumseh, Mo. & 561 & $11 / 1985$ & 28.10 & 133,000 & $4 / 64$ & 3/19/2008 & 22.79 & 60,600 \\
\hline 48 & 07058000 Bryant Creek near Tecumseh, Mo. & 570 & 12/1982 & 26.74 & 71,100 & 3/53 & 3/19/2008 & 22.12 & 42,800 \\
\hline 49 & 07060500 White River at Calico Rock, Ark. & 9,980 & 01/1916 & 52.90 & 350,000 & (c) & $3 / 19 / 2008$ & 39.64 & ${ }^{\prime} 197,000$ \\
\hline 50 & 07061000 White River at Batesville, Ark. & 11,100 & $02 / 1916$ & 31.90 & 382,000 & $17 / 93$ & 3/20/2008 & 26.96 & 208,000 \\
\hline 51 & 07061900 Logan Creek at Ellington, Mo. & 139 & 05/2002 & 13.22 & 16,300 & $1 / 15$ & $3 / 18 / 2008$ & 13.20 & 16,600 \\
\hline 52 & 07064000 Black River at Corning, Ark. & 1,749 & 03/1964 & 15.23 & 32,500 & 4/102 & $3 / 22 / 2008$ & 15.92 & 27,100 \\
\hline 53 & 07064533 Current River above Akers, Mo. & 295 & $11 / 2003$ & 7.07 & 5,540 & $1 / 7$ & 3/19/2008 & 18.52 & 29,500 \\
\hline 54 & 07065200 Jacks Fork near Mountain View, Mo. & 185 & 04/2004 & 17.68 & 17,400 & $1 / 6$ & 3/11/2008 & 20.39 & 23,600 \\
\hline 55 & 07065495 Jacks Fork at Alley Spring, Mo. & 298 & 11/1993 & 21.97 & 48,700 & $3 / 15$ & $3 / 19 / 2008$ & 15.23 & 30,000 \\
\hline 56 & 07067000 Current River at Van Buren, Mo. & 1,667 & 03/1904 & 29.00 & 153,100 & 10/96 & $3 / 20 / 2008$ & 25.71 & 82,600 \\
\hline 57 & 07068000 Current River at Doniphan, Mo. & 2,038 & 03/1904 & 24.90 & 130,000 & 4/92 & $3 / 19 / 2008$ & 24.11 & 95,200 \\
\hline 58 & 07069000 Black River at Pocahontas, Ark. & 4,840 & 04/1927 & 25.90 & 80,000 & $2 / 73$ & 3/22/2008 & 26.56 & ه72,200 \\
\hline 59 & 07069305 Spring River at Town Branch Bridge, Hardy, Ark. & 867 & 09/2006 & 16.75 & 44,500 & $1 / 7$ & $3 / 19 / 2008$ & 22.29 & 80,700 \\
\hline 60 & 07069500 Spring River at Imboden, Ark. & 1,180 & 12/1982 & 38.12 & 244,000 & 2/73 & $3 / 19 / 2008$ & 29.15 & 97,300 \\
\hline 61 & 07071500 Eleven Point River near Bardley, Mo. & 793 & $12 / 1982$ & 21.64 & 49,800 & $2 / 88$ & 3/19/2008 & 21.33 & 49,400 \\
\hline 62 & 07072000 Eleven Point River near Ravenden Springs, Ark. & 1,130 & 12/1982 & 29.06 & 162,000 & $2 / 77$ & $3 / 19 / 2008$ & 23.81 & 69,700 \\
\hline 63 & 07072500 Black River at Black Rock, Ark. & 7,370 & 12/1982 & 31.51 & 190,000 & $3 / 104$ & 3/20/2008 & 29.74 & 135,000 \\
\hline 64 & 07074420 Black River near Elgin Ferry, Ark. & 8,420 & 03/2002 & 26.33 & 59,500 & $1 / 17$ & 3/21/2008 & $e^{32.57}$ & "127,000 \\
\hline 65 & 07074500 White River at Newport, Ark. & 19,900 & 04/1927 & 35.60 & 387,000 & $8 / 123$ & $3 / 21 / 2008$ & 33.87 & 266,000 \\
\hline 66 & 07074850 White River near Augusta, Ark. & 20,500 & $02 / 1989$ & 35.54 & ${ }^{1} 140,000$ & $1 / 16$ & $3 / 22 / 2008$ & 38.41 & 252,000 \\
\hline 67 & 07076750 White River near Georgetown, Ark. & 22,400 & 12/1982 & 28.87 & f179,000 & $2 / 30$ & 3/24/2008 & 30.18 & ${ }^{f} 175,000$ \\
\hline 68 & 07185765 Spring River at Carthage, Mo. & 425 & 11/1972 & 17.15 & 24,800 & $1 / 20$ & $3 / 19 / 2008$ & 18.38 & -- \\
\hline 69 & 07187000 Shoal Creek above Joplin, Mo. & 427 & 05/1943 & 16.80 & 62,100 & $6 / 85$ & 3/19/2008 & 18.28 & 24,100 \\
\hline 70 & 07195000 Osage Creek near Elm Springs, Ark. & 130 & 05/1950 & 16.70 & 22,500 & $5 / 43$ & 3/118/2008 & 15.55 & 15,800 \\
\hline 71 & 07195500 Illinois River near Watts, Okla. & 635 & 07/1960 & 25.96 & 68,000 & $3 / 53$ & $3 / 19 / 2008$ & 24.73 & $\triangleleft_{53,000}$ \\
\hline 72 & 07196500 Illinois River near Tahlequah, Okla. & 959 & 05/1950 & 27.94 & 150,000 & $6 / 76$ & 3/20/2008 & 22.29 & 661,800 \\
\hline 73 & 07247250 Black Fork below Big Creek near Page, Okla. & 74.4 & 04/2002 & 20.94 & 23,300 & $1 / 16$ & 3/18/2008 & 23.36 & 34,600 \\
\hline 74 & 07257006 Big Piney at Highway 164 near Dover, Ark. & 306 & 12/1982 & 33.87 & 110,000 & $6 / 16$ & $3 / 18 / 2008$ & 21.76 & 73,700 \\
\hline 75 & 07260000 Dutch Creek at Waltreak, Ark. & 81.4 & 07/1969 & 22.38 & 24,500 & $2 / 73$ & 3/19/2008 & 20.00 & 22,400 \\
\hline 76 & 07261500 Fourche LaFave River near Gravelly, Ark. & 410 & 12/1982 & 32.45 & 162,000 & 2/69 & 3/19/2008 & 30.91 & 81,500 \\
\hline 77 & 07338750 Moun & 320 & 10/1998 & 30.40 & 46,500 & 1/15 & 3/19/2008 & 30.55 & 54,900 \\
\hline
\end{tabular}

${ }^{a}$ Rank of the maximum instantaneous peak streamflow measured during March 2008 compared
indicates that the March 2008 peak streamflow was higher than all other recorded annual peaks.

b Unless otherwise noted, expected peak streamflows are based on Water Resources Council Bulletin 17B weighting by variance method.

'The peak streamflow for March 2008 was exceeded by another peak streamflow during 2008.

${ }^{d}$ Streamflow affected to unknown degree by regulation or diversion.

'Peak stage was because of backwater. Backwater adjustments were made to the streamflow. Streamflow affected by regulation or diversion.

Expected peak streamflows based on Bulletin 17B systematic frequency-curve estimate only.

"Estimated.

Sreamgage previously was at a different location and datum (05599490 replaced 05599500 after 2007 and 07257006 replaced 07257000 after 1992).

Expected peak streamflows based on regional regression equation estimates only.

Estimated AEP based on Bulletin 17B expected probability method.

Expected peak streamflows based on Ries and Dillow method (2006) using 7 years of record

m Estimated AEP based on 2-station analysis using 17 non-consecutive years of record

Estimated AEP uncharacterized because of regulation or insufficient data.

\begin{tabular}{|c|c|c|c|c|c|c|c|c|c|c|c|c|}
\hline \multirow{4}{*}{$\begin{array}{l}\text { Estimated } \\
\text { AEP for } \\
\text { observed } \\
\text { peak } \\
\text { streamflow } \\
\text { (percent) }\end{array}$} & \multicolumn{12}{|c|}{ Expected peak streamflows for selected AEP with 95-percent confidence limits $\left(\mathrm{ft}^{2} / \mathrm{s}^{b}\right.$} \\
\hline & \multicolumn{3}{|c|}{$\begin{array}{l}\text { 4-percent AEP } \\
\text { (25-year recurrence) }\end{array}$} & \multicolumn{3}{|c|}{$\begin{array}{l}\text { 2-percent AEP } \\
\text { (50--year recurrence) }\end{array}$} & \multicolumn{3}{|c|}{$\begin{array}{c}\text { 19-percent AEP } \\
\text { (100-year recurrence) }\end{array}$} & \multicolumn{3}{|c|}{$\begin{array}{l}\text { 0.2-percent AEP } \\
\text { (500-year recurrence) }\end{array}$} \\
\hline & \multirow{2}{*}{ Estimate } & \multicolumn{2}{|c|}{ Confidence limit } & \multirow{2}{*}{ Estimate } & \multicolumn{2}{|c|}{ Confidence limit } & \multirow{2}{*}{ Estimate } & \multicolumn{2}{|c|}{ Confidence limit } & \multirow{2}{*}{ Estimate } & \multicolumn{2}{|c|}{ Confidence limit } \\
\hline & & Low & High & & Low & High & & Low & High & & Low & High \\
\hline $2-4$ & 57,800 & 40,900 & 81,800 & 72,500 & 49,100 & 107,000 & 87,400 & 57,100 & 134,000 & 121,000 & 74,100 & 199,000 \\
\hline $4-10$ & 45,200 & 34,500 & 59,200 & 55,900 & 41,100 & 76,100 & 67,500 & 47,900 & 95,300 & 96,500 & 63,300 & 147,000 \\
\hline${ }^{2}-4$ & -- & -- & -- & -- & -- & -- & -- & -- & -- & -- & -- & -- \\
\hline${ }^{2} 2-4$ & -- & -- & -- & -- & -- & -- & -- & -- & -- & -- & -- & -- \\
\hline $4-10$ & 22,300 & 13,600 & 36,600 & 27,500 & 16,500 & 45,900 & 32,800 & 19,400 & 55,500 & 45,400 & 25,900 & 79,400 \\
\hline $4-10$ & 828,700 & 24,200 & 35,500 & 833,000 & 27,500 & 41,600 & 837,300 & 30,700 & 47,900 & $\$ 47,100$ & 37,800 & 62,700 \\
\hline $4-10$ & $j_{34,800}$ & -- & -- & ${ }^{3} 41,700$ & -- & -- & i49,200 & -- & -- & ${ }^{3} 67,200$ & -- & -- \\
\hline $4-10$ & 28,400 & -- & -- & 34,300 & -- & -- & 400,600 & -- & -- & 56,000 & -- & -- \\
\hline$>10$ & 39,900 & 26,200 & 61,000 & 100 & 30,000 & 73,900 & 54,300 & 33,900 & 87,100 & 71,700 & 42,500 & 121,000 \\
\hline $4-10$ & 99,300 & 79,800 & 124,000 & 122,000 & 94,200 & 157,000 & 145,000 & 108,000 & 194,000 & 202,000 & 139,000 & 292,000 \\
\hline $4-10$ & 95,700 & 77,600 & 118,000 & 117,000 & 91,300 & 149,000 & 139,000 & 105,000 & 184,000 & 194,000 & 135,000 & 278,000 \\
\hline $2-4$ & 66,400 & 56,000 & 82,100 & 80,300 & 66,500 & 101,000 & 95,600 & 77,700 & 125,000 & 137,000 & 107,000 & 188,000 \\
\hline $2-4$ & 179,700 & -- & -- & 198,500 & -- & -- & '118,100 & -- & -- & -- & -- & -- \\
\hline $2-4$ & 94,700 & 77,000 & 123,000 & 120,000 & 95,400 & 160,000 & 149,000 & 116,000 & 205,000 & 232,000 & 172,000 & 341,000 \\
\hline $2-4$ & 46,900 & 36,100 & 60,900 & 60,440 & 44,700 & 81,700 & 75,400 & 53,600 & 106,000 & 114,000 & 74,700 & 174,000 \\
\hline $.2-1$ & 41,300 & 33,900 & 52,600 & 51,600 & 41,500 & 67,600 & 63,000 & 49,800 & 85,000 & 94,900 & 71,900 & 136,000 \\
\hline $2-4$ & 116,000 & 101,000 & 137,000 & 140,000 & 120,000 & 169,000 & 166,000 & 140,000 & 203,000 & 235,000 & 192,000 & 300,000 \\
\hline${ }^{\mathrm{m}} 1-2$ & -- & -- & -- & -- & -- & -- & -- & -- & -- & -- & -- & -- \\
\hline${ }^{2} 2-4$ & 238,000 & -- & -- & 306,000 & -- & -- & 389,000 & -- & -- & 666,000 & -- & -- \\
\hline$k_{2}-4$ & -- & -- & -- & -- & -- & -- & -- & -- & -- & -- & -- & -- \\
\hline$k_{2}-4$ & - & - & -- & -- & -- & -- & -- & -- & -- & -- & -- & -- \\
\hline${ }^{n_{--}}$ & 40,600 & 28,800 & 57,400 & 49,700 & 33,900 & 72,900 & 58,800 & 38,800 & 89,100 & 79,700 & 49,100 & 129,000 \\
\hline $4-10$ & 32,800 & 25,000 & 43,000 & 41,900 & 30,700 & 57,200 & 51,900 & 36,600 & 73,600 & 77,100 & 50,300 & 118,000 \\
\hline $4-10$ & 20,100 & 15,200 & 29,100 & 24,500 & 18,100 & 36,800 & 29,200 & 21,100 & 45,200 & 40,800 & 28,300 & 67,500 \\
\hline $2-4$ & 52,900 & 41,800 & 67,000 & 62,200 & 47,400 & 81,500 & 71,700 & 52,800 & 97,400 & 94,700 & 63,700 & 141,000 \\
\hline 4-10 & 71,800 & 56,600 & 91,000 & 89,400 & 67,700 & 118,000 & 109,000 & 79,200 & 150,000 & 163,000 & 107,000 & 249,000 \\
\hline $1-2$ & 29,500 & 20,600 & 42,400 & 34,600 & 23,200 & 51,700 & 39,800 & 25,700 & 61,900 & 53,200 & 31,100 & 91,100 \\
\hline 4-10 & 82,100 & 65,000 & 111,000 & 102,000 & 79,200 & 142,000 & 125,000 & 94,400 & 179,000 & 185,000 & 134,000 & 283,000 \\
\hline $1-2$ & 17,800 & 14,300 & 22,200 & 21,200 & 16,400 & 27,500 & 24,600 & 18,200 & 33,200 & 33,400 & 22,300 & 50,000 \\
\hline $1-2$ & 68,800 & 57,400 & 86,100 & 78,900 & 65,000 & 101,000 & 88,500 & 72,100 & 115,000 & 109,000 & 87,200 & 146,000 \\
\hline $2-4$ & 51,900 & 40,300 & 66,800 & 57,800 & 43,600 & 76,700 & 63,800 & 46,700 & 87,300 & 78,000 & 53,000 & 115,000 \\
\hline
\end{tabular}
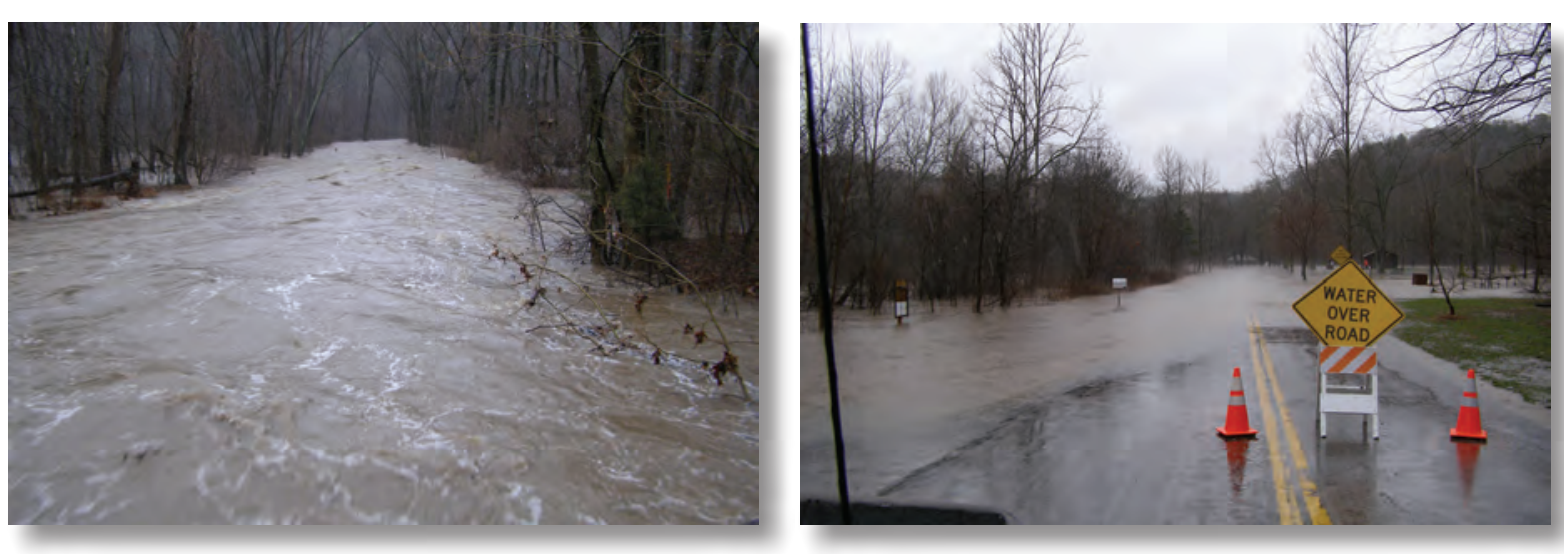

Flooding on the Current River at Montauk State Park, Montauk, Missouri. Photographs by Paul Rydlund, USGS. 
Table 4. Summary of peak stages, streamflows, and flood-probability estimates for selected U.S. Geological Survey streamgages during April 2008.

[mi2', square mile; ft, foot; fit3/s, cubic foot per second; AEP, annual exceedance probability; --, no data]

Flood data

\begin{tabular}{|c|c|c|c|c|c|c|c|c|c|c|}
\hline \multirow{3}{*}{$\begin{array}{l}\text { Site } \\
\text { number } \\
\text { (fig. 11) }\end{array}$} & \multirow{3}{*}{$\begin{array}{l}\text { Station } \\
\text { number }\end{array}$} & \multirow{3}{*}{ Station name } & \multirow{3}{*}{$\begin{array}{c}\text { Contributing } \\
\text { drainage } \\
\text { area } \\
\left(\mathrm{mi}^{2}\right)\end{array}$} & \multirow{2}{*}{\multicolumn{3}{|c|}{ Previous maximum streamflow }} & & & & \\
\hline & & & & & & & \multicolumn{4}{|c|}{ Flood of April 2008} \\
\hline & & & & Date & $\begin{array}{l}\text { Stage } \\
\text { (ft) }\end{array}$ & $\begin{array}{c}\text { Streamflow } \\
\left(t t^{2} / s\right)\end{array}$ & $\begin{array}{l}\text { Rank"/ } \\
\text { annual } \\
\text { peakss }\end{array}$ & Date & $\begin{array}{c}\text { Peak } \\
\text { stage } \\
\text { (ft) }\end{array}$ & $\begin{array}{l}\text { Peak } \\
\text { streammllow } \\
\text { (ttr/s) }\end{array}$ \\
\hline 1 & 05416200 & Lamont Creek Tributary near Lamont, Iowa & 1.8 & $06 / 2000$ & 20.13 & ${ }^{\circ} 635$ & $1 / 18$ & $4 / 25 / 2008$ & 23.18 & 1,190 \\
\hline 2 & 05420875 & Buck Creek near Oran, Iowa & 37.9 & 05/1999 & 91.02 & ${ }^{c 5,600}$ & $2 / 43$ & 4/25/2008 & 91.33 & 2,930 \\
\hline 3 & 05463500 & Black Hawk Creek at Hudson, Iowa & 303 & 07/1969 & 18.23 & 19,300 & $1 / 51$ & 4/25/2008 & 19.03 & 22,500 \\
\hline 4 & 06919020 & Sac River at Highway J below Stockton, Mo. & 1,292 & 09/1993 & 23.71 & 13,300 & $4 / 35$ & 4/10/2008 & 21.26 & ${ }^{d} 10,100$ \\
\hline 5 & 06919900 & Sac River near Caplinger Mills, Mo. & 1,810 & 04/1994 & 30.95 & 61,500 & $6 / 34$ & 4/11/2008 & 26.12 & ${ }_{223,300}$ \\
\hline 6 & 07050500 & Kings River near Berryville, Ark. & 527 & $11 / 1985$ & 38.91 & 66,000 & $5 / 80$ & 4/10/2008 & 35.29 & ${ }^{\circ 50,100}$ \\
\hline 7 & 07060500 & White River at Calico Rock, Ark. & 9,980 & 01/1916 & 52.90 & 350,000 & $11 / 116$ & $4 / 11 / 2008$ & 40.27 & $\mathrm{~d}_{202,000}$ \\
\hline 8 & 07060710 & North Sylamore Creek near Fifty Six, Ark. & 58.1 & 12/1982 & 20.60 & 25,200 & $1 / 54$ & $4 / 10 / 2008$ & 19.16 & 28,200 \\
\hline 9 & 07061000 & White River at Batesville, Ark. & 11,100 & $02 / 1916$ & 31.90 & 382,000 & (b) & 4/11/2008 & -- & ${ }^{d} 199,000$ \\
\hline 10 & 07071500 & Eleven Point River near Bardley, Mo. & 793 & 12/1982 & 21.64 & 49,800 & (") & 4/11/2008 & 19.72 & 41,400 \\
\hline 11 & 07072000 & Eleven Point River near Ravenden Springs, Ark. & 1,130 & 12/1982 & 29.06 & 162,000 & (b) & $4 / 11 / 2008$ & 21.35 & 43,600 \\
\hline 12 & 07072500 & Black River at Black Rock, Ark. & 7,370 & 12/1982 & 31.51 & 190,000 & (1) & 4/11/2008 & 28.67 & 108,000 \\
\hline 13 & 07074500 & White River at Newport, Ark. & 19,900 & 04/1927 & 35.60 & 387,000 & (b) & 4/13/2008 & -- & $\mathrm{d}_{237,000}$ \\
\hline 14 & 07077000 & White River at DeValls Bluff, Ark. & 23,400 & 04/1927 & 34.60 & ${ }^{d--}$ & 3/73 & 4/17/2008 & 31.41 & ${ }^{\top} 189,000$ \\
\hline 15 & 07185765 & Spring River at Carthage, Mo. & 425 & 11/1972 & 17.15 & 24,800 & (") & 4/10/2008 & 17.74 & -- \\
\hline 16 & 07188653 & Big Sugar Creek near Powell, Mo. & 141 & 05/2002 & 15.70 & 11,000 & $1 / 8$ & 4/10/2008 & 18.11 & 15,800 \\
\hline 17 & 07197000 & Baron Ford at Eldon, Okla. & 307 & 06/2000 & 26.77 & $\mathrm{i}_{54,700}$ & $5 / 63$ & 4/10/2008 & 23.50 & 399,600 \\
\hline 18 & 07249985 & Lee Creek near Short, Okla. & 420 & $04 / 1945$ & 35.00 & ${ }^{\prime} 112,000$ & $10 / 78$ & 4/10/2008 & 23.19 & 55,700 \\
\hline 19 & 07257500 & Illinois Bayou near Scottsville, Ark. & 241 & 12/1982 & 27.49 & 130,000 & $2 / 71$ & 4/10/2008 & 23.46 & 77,600 \\
\hline
\end{tabular}

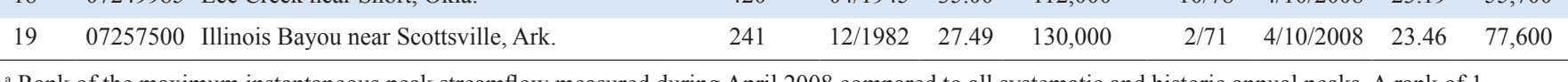
a Rank of the maximum instantaneous peak streamfllow measured during April 2008 compared to all systematic and historic annual peaks. A rank of 1
indicates that the April 2008 peak streamflow was higher than all other recorded annual peaks.

'Estimated.

${ }^{`}$ Estimated. Streamflow affected by regulation or diversion.

Estimated AEP uncharacterized because of regulation or insufficient dat.

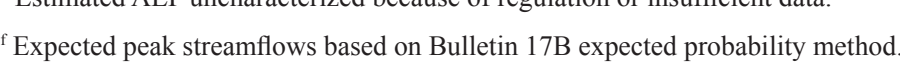

${ }^{8}$ Expected peak streamflows based on Bulletin 17B systematic frequency-curve estimate only.

"The peak streamflow for April 2008 was exceeded by another peak streamflow during 2008.

Expected peak streamflows based on regional regression equation estimates only

iStreamflow affected to unknown degree by regulation or diversion.

\begin{tabular}{|c|c|c|c|c|c|c|c|c|c|c|c|c|}
\hline \multirow{4}{*}{$\begin{array}{l}\text { Estimated } \\
\text { AEP for } \\
\text { observed } \\
\text { peak } \\
\text { streamflow } \\
\text { (percent) }\end{array}$} & \multicolumn{12}{|c|}{ Expected peak streamfllows for selected AEP with 95-percent confidence limits $\left(t^{t} t^{\prime} /\right)^{b}$} \\
\hline & \multicolumn{3}{|c|}{$\begin{array}{l}\text { 4-percent AEP } \\
\text { (25-year recurrence) }\end{array}$} & \multicolumn{3}{|c|}{$\begin{array}{l}\text { 2-percent AEP } \\
\text { (50-year recurrence) }\end{array}$} & \multicolumn{3}{|c|}{$\begin{array}{c}\text { 10-percent AEP } \\
\text { (100-year recurrence) }\end{array}$} & \multicolumn{3}{|c|}{$\begin{array}{l}\text { 0.2-percent AEP } \\
\text { (500-year recurrence) }\end{array}$} \\
\hline & \multirow{2}{*}{ Estimate } & \multicolumn{2}{|c|}{ Confidence limit } & \multirow{2}{*}{ Estimate } & \multicolumn{2}{|c|}{ Confidence limit } & \multirow{2}{*}{ Estimate } & \multicolumn{2}{|c|}{ Confidence limit } & \multirow{2}{*}{ Estimate } & \multicolumn{2}{|c|}{ Confidence limit } \\
\hline & & Low & High & & Low & High & & Low & High & & Low & High \\
\hline 4-10 & 1,380 & 1,030 & 1,840 & 1,770 & 1,300 & 2,410 & 2,200 & 1,580 & 3,060 & 3,380 & 2,260 & 5,050 \\
\hline $4-10$ & 3,630 & 2,840 & 4,640 & 4,650 & 3,560 & 6,080 & 5,720 & 4,270 & 7,660 & 8,440 & 5,880 & 12,100 \\
\hline $.2-1$ & 15,100 & 11,900 & 19,000 & 18,300 & 14,200 & 23,600 & 21,600 & 16,400 & 28,400 & 29,700 & 21,100 & 41,600 \\
\hline ¿- & -- & -- & -- & -- & -- & -- & -- & -- & -- & -- & -- & -- \\
\hline ¿- & -- & -- & -- & -- & -- & -- & -- & -- & -- & -- & -- & -- \\
\hline $4-10$ & 55,800 & 45,800 & 71,300 & 68,200 & 55,000 & 89,600 & 81,600 & 64,600 & 110,000 & 117,000 & 89,000 & 166,000 \\
\hline$\{2-1$ & -- & -- & -- & -- & -- & -- & -- & -- & - & - & -- & -- \\
\hline $.2-1$ & 817,000 & 12,400 & 23,300 & 820,000 & 14,300 & 28,000 & 822,800 & 15,900 & 32,500 & 829,500 & 19,700 & 44,300 \\
\hline$\therefore$ & -- & -- & -- & -- & -- & -- & -- & -- & - & -- & -- & -- \\
\hline $4-10$ & 46,900 & 36,100 & 60,900 & 60,400 & 44,700 & 81,700 & 75,400 & 53,600 & 106,000 & 114,000 & 74,700 & 174,000 \\
\hline $2-4$ & 41,300 & 33,900 & 52,600 & 51,600 & 41,500 & 67,600 & 63,000 & 49,800 & 85,000 & 94,900 & 71,900 & 136,000 \\
\hline $4-10$ & 116,000 & 101,000 & 137,000 & 140,000 & 120,000 & 169,000 & 166,000 & 140,000 & 203,000 & 235,000 & 192,000 & 300,000 \\
\hline $4-10$ & 238,000 & -- & -- & 306,000 & -- & -- & 389,000 & -- & -- & 666,000 & -- & -- \\
\hline $2-4$ & -- & -- & -- & - & -- & -- & - & -- & -- & -- & - & -- \\
\hline$\therefore$ & 40,600 & 28,800 & 57,400 & 49,700 & 33,900 & 72,900 & 58,800 & 38,800 & 89,100 & 79,700 & 49,100 & 129,000 \\
\hline $4-10$ & 21,400 & -- & -- & 25,700 & -- & -- & 30,400 & -- & -- & 41,500 & -- & -- \\
\hline $4-10$ & 51,000 & 39,300 & 66,200 & 60,900 & 45,200 & 82,000 & 70,900 & 50,600 & 99,500 & 95,300 & 61,500 & 148,000 \\
\hline$>10$ & 74,800 & 59,900 & 93,200 & 89,200 & 69,100 & 115,000 & 104,000 & 77,800 & 139,000 & 142,000 & 96,700 & 209,000 \\
\hline $1-2$ & 61,300 & 49,600 & 80,400 & 76,400 & 60,400 & 103,000 & 93,200 & 72,100 & 130,000 & 140,000 & 104,000 & 209,000 \\
\hline
\end{tabular}

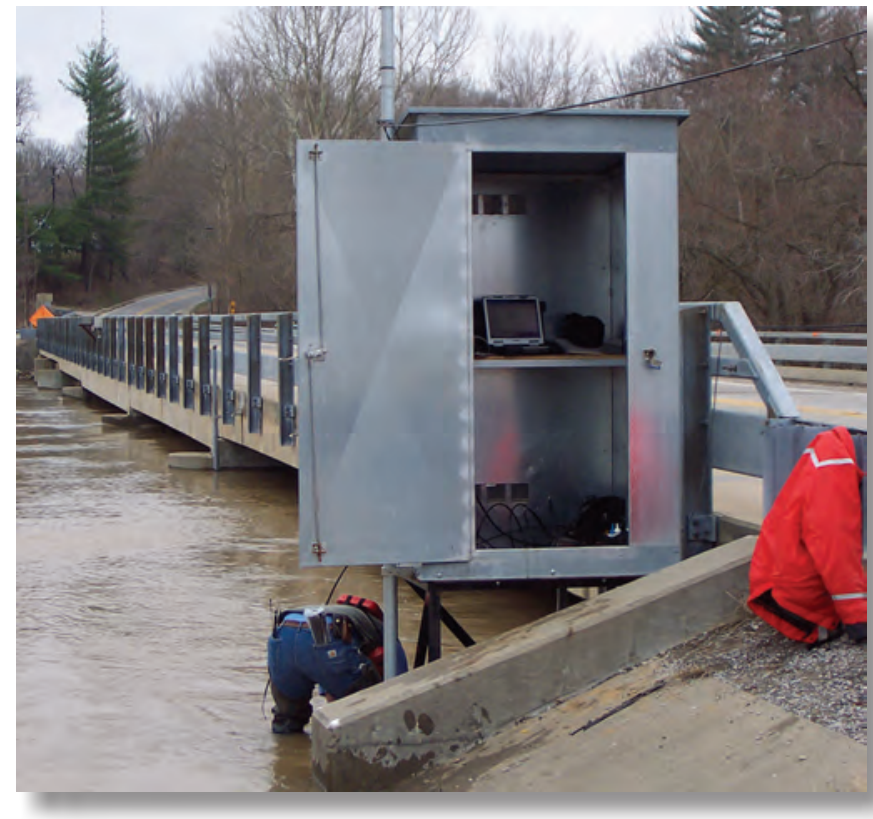

Hydrographer working to repair instrumentation on the Big Muddy River at Murphysboro, Illinois (USGS streamgage 05599490). River at Murphysboro, Illinois USGS
Photograph by Robert Holmes, USGS.

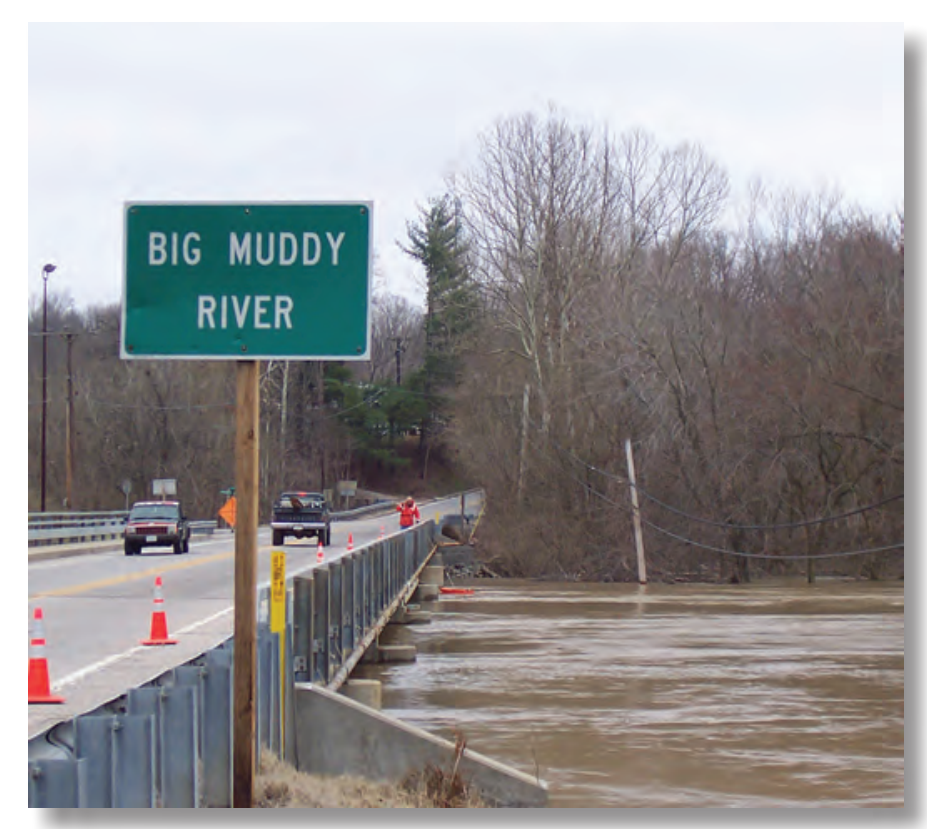

Hydrographer making a streamflow measurement on the Big Muddy Hydrographer makimg a streamflow measurement on the Big Muddy
at Murphysboro, Ilinois (USGS streamgage 05599490). Photograph by
Robert Holmes, USGS. 
Table 5. Summary of peak stages, streamflows, and flood-probability estimates for selected U.S. Geological Survey streamgages during May and June 2008.

[mi2', square mile; ft, foot; fťs, cubic foot per second; AEP, annual exceedance probability; $>$, greater than; $<$, less than; ;-, no data; R., River]

\begin{tabular}{|c|c|c|c|c|c|c|c|c|c|c|}
\hline \multirow{3}{*}{$\begin{array}{c}\text { Site } \\
\text { number } \\
\text { (fig. 12) }\end{array}$} & \multirow{3}{*}{$\begin{array}{l}\text { Station } \\
\text { number }\end{array}$} & \multirow{3}{*}{ Station name } & \multirow{3}{*}{$\begin{array}{c}\text { Contributing } \\
\text { drainage } \\
\text { area } \\
\text { (mi') }\end{array}$} & \\
\hline & & & & \multicolumn{3}{|c|}{ Previous maximum streamflow } & \multicolumn{4}{|c|}{ Flood of June 2008} \\
\hline & & & & Date & $\begin{array}{c}\text { Stage } \\
(\mathrm{ft})\end{array}$ & $\begin{array}{c}\text { Streamflow } \\
\left(\mathrm{ft}^{\mathrm{t}} / \mathrm{s}\right)\end{array}$ & $\begin{array}{l}\text { Ranke/ } \\
\text { annual } \\
\text { peaks }\end{array}$ & Date & $\begin{array}{l}\text { Peak } \\
\text { stage } \\
\text { (ft) }\end{array}$ & $\begin{array}{c}\text { Peak } \\
\text { streamflow } \\
\left(\mathrm{ft}^{2} / \mathrm{s}\right)\end{array}$ \\
\hline & 03341500 & Wabash River at Terre Haute, Ind. & 12,263 & $03 / 1913$ & 31.20 & 245,000 & $27 / 118$ & $6 / 8 / 2008$ & 25.02 & ${ }^{\circ} 92,400$ \\
\hline 2 & 03342000 & Wabash River at Riverton, Ind. & 13,161 & $03 / 1913$ & $\mathrm{~d}_{26.40}$ & 250,000 & $10 / 73$ & $6 / 10 / 2008$ & 26.56 & 98,100 \\
\hline 3 & 03345500 & Embarras River at Ste. Marie, Ill. & 1,516 & $01 / 1950$ & 25.95 & 44,800 & $1 / 98$ & 6/7/2008 & 28.06 & 60,400 \\
\hline 4 & 03346000 & North Fork Embarras River Near Oblong, Ill. & 318 & $01 / 1950$ & 24.38 & 27,100 & $1 / 68$ & 6/7/2008 & 26.26 & 46,200 \\
\hline 5 & 03353637 & Little Buck Creek near Indianapolis, Ind. & 17.0 & $12 / 1990$ & d9.10 & 2,300 & $1 / 19$ & 6/7/2008 & 13.01 & 2,850 \\
\hline 6 & 03354000 & White River near Centerton, Ind. & 2,444 & $03 / 1913$ & 21.90 & 90,000 & $2 / 65$ & 6/7/2008 & 19.85 & ‘63,500 \\
\hline 7 & 03357350 & Plum Creek near Bainbridge, Ind. & 3.0 & 09/1989 & 6.50 & 940 & $1 / 39$ & 6/4/2008 & 7.15 & 1,000 \\
\hline 8 & 03358000 & Mill Creek near Cataract, Ind. & 245 & 12/1990 & -- & 12,200 & $3 / 59$ & 6/7/2008 & 22.61 & 10,800 \\
\hline 9 & 03360500 & White River at Newberry, Ind. & 4,688 & $03 / 1913$ & 27.50 & 130,000 & 1/102 & 6/9/2008 & 28.59 & ${ }^{\circ} 138,000$ \\
\hline 10 & 03362000 & Youngs Creek near Edinburgh, Ind. & 107 & 01/1952 & 13.40 & 10,700 & $1 / 66$ & 6/7/2008 & 15.67 & 20,500 \\
\hline 11 & 03362500 & Sugar Creek near Edinburgh, Ind. & 474 & $05 / 1956$ & 18.38 & 27,600 & $1 / 66$ & 6/7/2008 & 19.23 & 39,900 \\
\hline 12 & 03363500 & Flatrock River at St. Paul, Ind. & 303 & $01 / 1949$ & ${ }^{d} 10.60$ & 18,500 & 6/78 & 6/7/2008 & 12.82 & 16,400 \\
\hline 13 & & & 534 & & 16.45 & & $1 / 41$ & & 19.94 & 62,500 \\
\hline 14 & 03364000 & East Fork White River at Columbus, Ind. & 1,707 & $03 / 1913$ & 17.90 & 100,000 & $2 / 64$ & 6/8/2008 & 18.61 & 68,100 \\
\hline 15 & 03364500 & Clifty Creek at Hartsville, Ind. & 91.4 & $03 / 1913$ & 25.10 & 20,000 & $2 / 62$ & 6/7/2008 & 17.85 & 16,200 \\
\hline 16 & 03365500 & East Fork White River at Seymou & 2,341 & $03 / 1913$ & 21.00 & 120,000 & $2 / 86$ & 6/8/2008 & 20.91 & 96,400 \\
\hline 17 & 03374000 & White River at Petersburg, Ind. & 11,125 & $03 / 1913$ & 29.50 & 235,000 & $7 / 86$ & $6 / 12 / 2008$ & 26.96 & ${ }^{\circ} 135,000$ \\
\hline 18 & 03377500 & Wabash River at Mount Carmel, III. & 28,635 & $03 / 1913$ & 33.00 & 428,000 & $11 / 128$ & $6 / 14 / 2008$ & 33.24 & 255,000 \\
\hline 19 & & Fox River at Berlin, Wis. & & 03/1946 & ${ }^{d} 15.50$ & 6,900 & $5 / 111$ & $6 / 22 / 2008$ & ‘ 16.08 & 6,020 \\
\hline 20 & 04085427 & Manitowoc River at Manitowoc, Wis. & 526 & 03/1979 & ${ }^{\mathrm{d}} 13.24$ & 8,280 & 2/35 & 6/13/2008 & 12.04 & 6,100 \\
\hline 21 & 04086000 & Sheboygan River at Sheboygan, Wis. & 418 & 08/1998 & ${ }^{\mathrm{f}} 12.02$ & 7,820 & $3 / 65$ & 6/9/2008 & 11.08 & 6,810 \\
\hline 22 & 04086600 & Milwauke & 607 & 05/2004 & 13.11 & 5,7 & $1 / 27$ & 6/13/2008 & 13.98 & 6,980 \\
\hline 23 & 04087000 & Milwaukee River at Milwaukee, & 696 & & 10.00 & 16,5 & 6/94 & 6/7/2008 & 8.07 & 10,4 \\
\hline 24 & 04087204 & Oak Creek at South Milwaukee, Wis. & 25.0 & $08 / 1986$ & 9.88 & 1,140 & $1 / 45$ & 6/7/2008 & 11.56 & 2,370 \\
\hline 25 & 04087220 & Root River near Franklin, Wis. & 49.2 & $03 / 1960$ & 9.57 & 5,130 & $1 / 46$ & 6/8/2008 & 11.00 & 5,350 \\
\hline 26 & 04087233 & Root River Canal near Franklin, & 57. & 03/1974 & 9.88 & 1,4 & $1 / 45$ & 9/2008 & 12.13 & 1,560 \\
\hline 27 & 04087240 & Root River at Racine, Wis. & 189 & 03/1974 & 8.54 & 4,500 & $1 / 45$ & 6/9/2008 & 11.29 & 8,050 \\
\hline 28 & 04087257 & Pike River near Racine, Wis. & 38.5 & 08/2007 & 8.24 & 1,720 & $1 / 37$ & 6/8/2008 & 8.97 & 1,960 \\
\hline 29 & 04108600 & Rabbit River near Hopkins, Mich. & 71.4 & 06/1997 & 11.11 & $n, 74$ & $3 / 44$ & 8/2008 & 9.37 & 1,770 \\
\hline 30 & 04122500 & Pere Marquette River at Scottville, Mich. & 681 & $09 / 1986$ & 8.07 & 6,44 & $2 / 69$ & $6 / 13 / 2008$ & 5.81 & 3,110 \\
\hline 31 & 04124000 & near Sherman, Mich. & 60.8 & & 7.10 & 3,5 & $5 / 89$ & 6/14/2008 & 16.37 & 3,200 \\
\hline 32 & 04124200 & Manistee River near Mesick, Mich. & 1,018 & $03 / 2006$ & 6.38 & ${ }^{3}, 150$ & $1 / 11$ & 6/14/2008 & 6.87 & 3,690 \\
\hline 33 & 04124500 & East Branch Pine River near Tustin, $\mathrm{P}$ & 60.0 & & & 876 & $3 / 53$ & & 6.26 & 760 \\
\hline 34 & 04125460 & Pine River & 245 & & 6.82 & 2,440 & $1 / 42$ & 6/14/2008 & 9.29 & 2,870 \\
\hline 35 & 04125550 & Manistee River near Wellston, Mich. & 1,451 & $03 / 1998$ & 10.91 & 6,130 & $1 / 12$ & 6/14/2008 & 11.06 & ${ }^{6} 6,500$ \\
\hline 36 & 05385500 & & 275 & & 14.90 & 13,80 & & & .35 & \\
\hline 37 & 05387440 & Upper Iowa River at Bluffton, Iowa & 367 & & 12.66 & 8,440 & $1 / 6$ & & 15.49 & 16,600 \\
\hline 38 & 05387490 & Dry Run Creek near Decorah, Iowa & 21.0 & 08/1993 & 20.80 & 4,620 & $1 / 26$ & 8/2008 & 21.53 & 5,820 \\
\hline 39 & 05387500 & & 511 & $08 / 1993$ & ${ }^{\mathrm{h}} 14.35$ & 20,500 & $1 / 57$ & $1 / 2008$ & 190 & \\
\hline 40 & & Upp & 770 & & 21.80 & 30,400 & $1 / 33$ & 6/9/2008 & 22.46 & 31,200 \\
\hline 41 & 05388310 & Waterloo Creek near Dorchester, Iowa & 43.6 & $07 / 1978$ & 14.80 & 9,380 & $2 / 39$ & 6/8/2008 & 14.57 & 8,800 \\
\hline 42 & 05404116 & West Branch Be & 39.1 & 06/1990 & 15.26 & & $1 / 21$ & /2008 & 12 & \\
\hline 43 & & & & & & & & & 48 & \\
\hline 44 & 05408000 & Kickapoo River at La Farge, Wis. & 266 & $07 / 1978$ & 14.92 & 14,300 & $1 / 70$ & 6/8/2008 & 15.78 & 22,100 \\
\hline 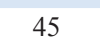 & 05410490 & 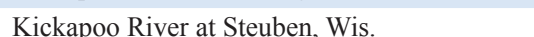 & 687 & $07 / 1978$ & 14.81 & .500 & $1 / 75$ & 6/10/2008 & 16 & \\
\hline & & & & 05/2004 & & 700 & $1 / 9$ & & 21.46 & \\
\hline
\end{tabular}

\begin{tabular}{|c|c|c|c|c|c|c|c|c|c|c|c|c|}
\hline \multirow{4}{*}{$\begin{array}{l}\text { Estimated } \\
\text { AEP for } \\
\text { observed } \\
\text { peak } \\
\text { streamflow } \\
\text { (percent) }\end{array}$} & \multicolumn{12}{|c|}{ Expected peak streamflows for selected AEP with 95-percent confidence limits $\left(\mathrm{ft}^{2} / \mathrm{s}^{b}\right.$} \\
\hline & \multicolumn{3}{|c|}{$\begin{array}{l}\text { 4-percent AEP } \\
\text { (25-year recurrence) }\end{array}$} & \multicolumn{3}{|c|}{$\begin{array}{l}\text { 2-percent AEP } \\
\text { (50--year recurrence) }\end{array}$} & \multicolumn{3}{|c|}{$\begin{array}{c}\text { 1-percent AEP } \\
\text { (100-year recurrence) } \\
\end{array}$} & \multicolumn{3}{|c|}{$\begin{array}{c}\text { 0.2-percent AEP } \\
\text { (500-year recurrence) }\end{array}$} \\
\hline & \multirow{2}{*}{ Estimate } & \multicolumn{2}{|c|}{ Confidence limit } & \multirow{2}{*}{ Estimate } & \multicolumn{2}{|c|}{ Confidence limit } & \multirow{2}{*}{ Estimate } & \multicolumn{2}{|c|}{ Confidence limit } & \multirow{2}{*}{ Estimate } & \multicolumn{2}{|c|}{ Confidence limit } \\
\hline & & Low & High & & Low & High & & Low & High & & Low & High \\
\hline$>10$ & 139,000 & 125,000 & 154,000 & 156,000 & 138,000 & 177,000 & 174,000 & 150,000 & 201,000 & 213,000 & 174,000 & 260,000 \\
\hline$>10$ & 134,000 & 121,000 & 149,000 & 152,000 & 134,000 & 172,000 & 169,000 & 146,000 & 196,000 & 208,000 & 171,000 & 254,000 \\
\hline $.2-1$ & 41,500 & 34,200 & 50,300 & 49,100 & 39,100 & 61,700 & 56,900 & 43,700 & 74,200 & 76,100 & 53,300 & 109,000 \\
\hline $.2-1$ & 26,100 & 20,500 & 33,200 & 31,000 & 23,400 & 41,000 & 35,900 & 26,000 & 49,600 & 47,500 & 31,000 & 72,800 \\
\hline $1-2$ & 2,450 & 2,220 & 2,700 & 2,800 & 2,490 & 3,150 & 3,160 & 2,750 & 3,620 & 4,070 & 3,380 & 4,900 \\
\hline $2-4$ & 55,500 & 49,800 & 61,900 & 63,700 & 56,000 & 72,400 & 71,900 & 62,000 & 83,500 & 91,600 & 75,400 & 111,000 \\
\hline $2-4$ & 909 & 741 & 1,120 & 1,050 & 839 & 1,320 & 1,200 & 935 & 1,540 & 1,550 & 1,150 & 2,080 \\
\hline $4-10$ & 11,300 & 9,660 & 13,300 & 13,000 & 10,900 & 15,600 & 14,700 & 12,000 & 18,000 & 18,700 & 14,600 & 23,800 \\
\hline$<.2$ & 79,700 & 70,700 & 89,800 & 91,700 & 79,500 & 106,000 & 104,000 & 88,100 & 123,000 & 135,000 & 107,000 & 170,000 \\
\hline$<.2$ & 8,670 & 7,070 & 10,600 & 9,820 & 7,840 & 12,300 & 10,800 & 8,500 & 13,800 & 13,000 & 9,860 & 17,200 \\
\hline$<.2$ & 20,600 & 17,000 & 25,000 & 23,700 & 19,100 & 29,400 & 26,500 & 21,000 & 33,500 & 32,800 & 25,000 & 43,000 \\
\hline $2-4$ & 16,300 & 13,700 & 19,300 & 18,600 & 15,400 & 22,500 & 20,800 & 16,900 & 25,700 & 25,700 & 20,000 & 33,100 \\
\hline$<.2$ & 24,200 & 19,100 & 30,600 & 27,900 & 21,700 & 35,900 & 31,100 & 23,800 & 40,700 & 38,500 & 28,600 & 51,800 \\
\hline $1-2$ & 57,000 & 48,600 & 66,900 & 65,600 & 54,600 & 78,700 & 73,500 & 60,000 & 90,100 & 91,300 & 71,300 & 117,000 \\
\hline $.2-1$ & 10,500 & 8,920 & 12,300 & 12,800 & 10,600 & 15,400 & 15,200 & 12,300 & 18,800 & 21,400 & 16,200 & 28,100 \\
\hline $.2-1$ & 74,300 & 66,300 & 83,200 & 83,200 & 72,700 & 95,200 & 91,100 & 78,000 & 107,000 & 108,000 & 88,300 & 133,000 \\
\hline $4-10$ & 153,000 & 139,000 & 170,000 & 173,000 & 153,000 & 195,000 & 191,000 & 166,000 & 221,000 & 235,000 & 192,000 & 286,000 \\
\hline $4-10$ & 281,000 & 252,000 & 315,000 & 311,000 & 272,000 & 356,000 & 339,000 & 289,000 & 398,000 & 397,000 & 318,000 & 494,000 \\
\hline $4-10$ & 6,340 & 5,650 & 7,110 & 7,060 & 6,150 & 8,100 & 7,770 & 6,610 & 9,140 & 9,290 & 8,250 & 10,700 \\
\hline $4-10$ & 6,270 & 4,990 & 8,580 & 7,450 & 5,800 & 10,600 & 8,690 & 6,630 & 12,800 & 11,900 & 8,650 & 18,600 \\
\hline $4-10$ & 7,630 & 6,350 & 9,170 & 8,610 & 6,950 & 10,700 & 9,550 & 7,450 & 12,200 & 11,600 & 9,460 & 15,100 \\
\hline $1-2$ & 6,100 & 5,080 & 7,940 & 6,940 & 5,680 & 9,320 & 7,790 & 6,270 & 10,800 & 9,870 & 7,640 & 14,600 \\
\hline $4-10$ & 11,000 & 9,250 & 13,000 & 12,700 & 10,400 & 15,500 & 14,600 & 11,600 & 18,300 & 19,600 & 16,500 & 24,300 \\
\hline$<.2$ & 1,230 & 975 & 1,540 & 1,400 & 1,070 & 1,850 & 1,590 & 1,150 & 2,200 & 2,310 & 1,870 & 3,110 \\
\hline $1-2$ & 83,430 & 2,730 & 4,630 & ${ }^{84,340}$ & 3,360 & 6,110 & 85,390 & 4,070 & 7,900 & 88,510 & 6,050 & 13,600 \\
\hline $2-4$ & 1,470 & 1,250 & 1,720 & 1,610 & 1,340 & 1,950 & 1,760 & 1,410 & 2,190 & 2,020 & 1,710 & 2,550 \\
\hline$<.2$ & 4,130 & 3,240 & 5,260 & 4,760 & 3,570 & 6,340 & 5,400 & 3,860 & 7,570 & 8,030 & 6,330 & 11,100 \\
\hline $1-2$ & ${ }^{8} 1,740$ & 1,510 & 2,110 & ${ }^{8} 1,900$ & 1,630 & 2,340 & 82,040 & 1,740 & 2,550 & ${ }^{2}, 330$ & 1,950 & 2,990 \\
\hline $2-4$ & 1,550 & 1,140 & 2,100 & 1,830 & 1,270 & 2,620 & 2,120 & 1,400 & 3,200 & -- & -- & -- \\
\hline $4-10$ & $8_{3,540}$ & 3,210 & 4,010 & 83,930 & 3,520 & 4,510 & ${ }^{84}, 310$ & 3,820 & 5,020 & ${ }^{85,190}$ & 4,520 & 6,210 \\
\hline $4-10$ & 83,240 & 3,090 & 3,440 & 83,420 & 3,240 & 3,640 & ${ }^{83,580}$ & 3,380 & 3,840 & 83,920 & 3,680 & 4,250 \\
\hline $4-10$ & 83,740 & 3,220 & 4,900 & 83,970 & 3,390 & 5,370 & 84,190 & 3,530 & 5,820 & 84,640 & 3,830 & 6,810 \\
\hline $2-4$ & ${ }^{8755}$ & 645 & 925 & ${ }^{8} 844$ & 712 & 1,050 & 8927 & 774 & 1,170 & ${ }^{8} 1,110$ & 905 & 1,440 \\
\hline $.2-1$ & ${ }^{22,150}$ & 1,870 & 2,590 & 82,440 & 2,090 & 3,020 & 82,750 & 2,320 & 3,470 & ${ }^{83,500}$ & 2,860 & 4,640 \\
\hline $2-4$ & 86,220 & 5,440 & 7,950 & ${ }^{86,680}$ & 5,760 & 8,830 & ${ }^{87,130}$ & 6,060 & 9,720 & 88,150 & 6,720 & 11,900 \\
\hline $4-10$ & 11,900 & 8,800 & 16,200 & 15,400 & 10,900 & 21,600 & 19,100 & 12,900 & 28,100 & 29,100 & 17,600 & 48,000 \\
\hline $2-4$ & ${ }^{i} 16,300$ & -- & -- & '19,300 & -- & -- & 22,300 & -- & -- & 229,600 & -- & -- \\
\hline $1-2$ & 4,590 & 3,750 & 5,620 & 5,530 & 4,420 & 6,910 & 6,530 & 5,100 & 8,360 & 9,150 & 6,700 & 12,500 \\
\hline $.2-1$ & ${ }^{1} 19,200$ & 16,200 & 22,700 & i22,800 & 18,800 & 27,600 & 26,400 & 21,300 & 32,800 & 35,300 & 26,700 & 46,600 \\
\hline $.2-1$ & 21,800 & 18,000 & 26,500 & 26,500 & 21,300 & 32,900 & 31,200 & 24,600 & 39,700 & 42,800 & 31,600 & 58,100 \\
\hline $2-4$ & 7,470 & 5,690 & 9,800 & 9,520 & 7,110 & 12,800 & 11,600 & 8,480 & 16,000 & 17,200 & 11,600 & 25,300 \\
\hline $1-2$ & 3,990 & 2,490 & & & 2,870 & 8,340 & 5,830 & 3,200 & 10,600 & 6,330 & 3,240 & 12,400 \\
\hline$<.2$ & 8,320 & 6,690 & 10,300 & 9,990 & 7,720 & 12,900 & 11,800 & 8,710 & 16,000 & 14,800 & 11,900 & 19,700 \\
\hline $.2-1$ & 8,870 & 6,460 & 12,200 & 11,400 & 7,790 & 16,600 & 14,300 & 9,160 & 22,200 & 23,500 & 17,400 & 34,700 \\
\hline $.2-1$ & 11,500 & 8,280 & & & 10,200 & & & 12,200 & & 32,700 & 23,800 & \\
\hline 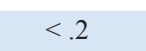 & i22,400 & & & 26,440 & & & 30,200 & & & 39,700 & & \\
\hline
\end{tabular}


Table 5. Summary of peak stages, streamflows, and flood-probability estimates for selected U.S. Geological Survey streamgages during May and June 2008.-Continued

[mi², square mile; ft, foot; fi³s, cubic foot per second; AEP, annual exceedance probability; $>$, greater than; $<$, less than; ;-, no data; R., River]

\begin{tabular}{|c|c|c|c|c|c|c|c|c|c|c|}
\hline \multirow{3}{*}{$\begin{array}{c}\text { Site } \\
\text { number } \\
\text { (fig. 12) }\end{array}$} & \multirow{3}{*}{$\begin{array}{l}\text { Station } \\
\text { number }\end{array}$} & \multirow{3}{*}{ Station name } & \multirow{3}{*}{$\begin{array}{c}\text { Contributing } \\
\text { drainage } \\
\text { area } \\
\left(\mathrm{mi}^{2}\right)\end{array}$} & \\
\hline & & & & \multicolumn{3}{|c|}{ Previous maximum streamflow } & \multicolumn{4}{|c|}{ Flood of June 2008} \\
\hline & & & & Date & $\begin{array}{c}\text { Stage } \\
(\text { fft }\end{array}$ & 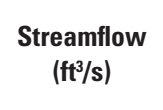 & $\begin{array}{l}\text { Ranka/ } \\
\text { annual } \\
\text { peaks }\end{array}$ & Date & $\begin{array}{c}\text { Peak } \\
\text { stage } \\
\text { (ft) }\end{array}$ & $\begin{array}{c}\text { Peak } \\
\text { streantlow } \\
\left(\mathbf{t}^{2} / \mathrm{s}\right)\end{array}$ \\
\hline 47 & 05412020 & Turkey River, French Hollow Creek, Elkader, Iowa & 903 & $06 / 1991$ & 27.32 & 38,300 & $1 / 8$ & $6 / 10 / 2008$ & 27.77 & 40,500 \\
\hline 48 & 05412400 & Volga River at Littleport, Iowa & 348 & $05 / 1999$ & 25.36 & n30,000 & $3 / 12$ & 6/8/2008 & 20.41 & 18,900 \\
\hline 49 & 05412500 & Turkey River at Garber, Iowa & 1,545 & 05/2004 & 32.80 & 66,700 & 4/90 & 6/10/2008 & 29.13 & 45,500 \\
\hline 50 & 05414000 & Platte River near Rockville, Wis. & 142 & $07 / 1950$ & 17.26 & 43,500 & $4 / 74$ & 6/12/2008 & "14.17 & ${ }^{n} 15,200$ \\
\hline 51 & 05414350 & Little Maquoketa River near Graf, Iowa & 39.6 & 06/2002 & 15.93 & 7,700 & $1 / 58$ & 6/8/2008 & 16.47 & 8,370 \\
\hline 52 & 05414450 & N. Fork Little Maquoketa River, Rickardsville, Iowa & 21.6 & $08 / 1972$ & 14.02 & 7,180 & $1 / 58$ & 6/8/2008 & 12.58 & 8,040 \\
\hline 53 & 05414605 & Bloody Run Tributary near Sherrill, Iowa & .6 & 06/1991 & 19.27 & "6992 & 1/18 & 6/8/2008 & 22.71 & 1,110 \\
\hline 54 & 05416900 & Maquoketa River at Manchester, Iowa & 275 & $05 / 2004$ & 21.66 & 26,000 & $2 / 8$ & $5 / 26 / 2008$ & 20.80 & 22,100 \\
\hline 55 & 05418400 & North Fork Maquoketa River near Fulton, Iowa & 505 & 06/2002 & 19.87 & 22,600 & $2 / 10$ & $6 / 13 / 2008$ & 18.67 & 20,700 \\
\hline 56 & 05419000 & Apple River near Hanover, IIl. & 247 & 06/2002 & 27.91 & 13,700 & 5/74 & 6/9/2008 & 25.20 & 11,300 \\
\hline 57 & 05420680 & Wapsipinicon River near Tripoli, Iowa & 346 & 07/1999 & 18.50 & 19,400 & $3 / 13$ & 6/9/2008 & 18.24 & 18,300 \\
\hline 58 & 05421000 & Wapsipinicon River at Independence, Iowa & 1,048 & $05 / 1999$ & 22.35 & 31,100 & $4 / 75$ & $6 / 11 / 2008$ & 18.86 & 23,700 \\
\hline 59 & 05421740 & Wapsipinicon River near Anamosa, Iowa & 1,575 & 05/2004 & 22.73 & n22,000 & $1 / 7$ & 6/13/2008 & 26.18 & 31,800 \\
\hline 60 & 05422000 & Wapsipinicon River at DeWitt, Iowa & 2,336 & $05 / 2004$ & 13.79 & 31,500 & $1 / 74$ & 6/16/2008 & ${ }^{\mathrm{d}} 14.13$ & 36,400 \\
\hline 61 & 05422470 & Crow Creek at Bettendorf, Iowa & 17.8 & 06/1990 & 11.03 & 7,700 & $2 / 30$ & 6/13/2008 & 9.56 & 3,590 \\
\hline 62 & 05422600 & Duck Creek, DC Golf Course, Davenport, Iowa & 57.3 & 06/2002 & 16.34 & 7,310 & 1/15 & 6/13/2008 2 , & 16.60 & 7,570 \\
\hline 63 & 05423500 & South Branch Rock River at Waupun, Wis. & 63.6 & 04/1959 & d7.97 & 1,500 & $1 / 42$ & 6/13/2008 & 10.09 & 2,350 \\
\hline 64 & 05425500 & Rock River at Watertown, Wis. & 969 & $03 / 1979$ & ${ }^{\mathrm{d}} 6.19$ & ${ }^{\circ}, 080$ & $1 / 71$ & $6 / 13 / 2008$ & 7.81 & 7,600 \\
\hline 65 & 05425912 & Beaver Dam River at Beaver Dam, Wis. & 157 & 06/2004 & 10.68 & ${ }^{1} 1,140$ & 1/23 & 6/16/2008 & e845.53 & '1,700 \\
\hline 66 & 05426000 & Crawfish River at Milford, Wis. & 762 & 04/1959 & 11.15 & 6,140 & 1/77 & 6/16/2008 & 13.35 & 7,190 \\
\hline 67 & 05426250 & Bark River near Rome, Wis. & 122 & $04 / 1993$ & 2.56 & 476 & $2 / 25$ & 6/9/2008 & 4.59 & 1,370 \\
\hline 68 & 05427570 & Rock River at Indianford, Wis. & 2,630 & $04 / 1979$ & 16.23 & ${ }^{\prime 11,900}$ & $1 / 33$ & $6 / 21 / 2008$ & 18.33 & ${ }^{\top} 4,900$ \\
\hline 69 & 05427718 & Yahara River at Windsor, Wis. & 37.0 & 07/1993 & 6.58 & 2,050 & $1 / 24$ & 6/9/2008 & 6.97 & 3,290 \\
\hline 70 & 05429500 & Yahara River at McFarland, Wis. & 290 & $04 / 1959$ & ${ }^{\mathrm{d}} .82$ & 1867 & $1 / 76$ & 6/14/2008 & ${ }^{\mathrm{d}} 7.17$ & 1976 \\
\hline 71 & 05430500 & Rock River at Afton, Wis. & 3,340 & 03/1929 & ${ }^{d} 11.80$ & ' 13,000 & $1 / 95$ & 6/21/2008 2 . & 13.51 & ' 16,700 \\
\hline 72 & 05437500 & Rock River at Rockton, IIll. & 6,363 & $03 / 1916$ & 13.06 & 32,500 & $4 / 80$ & 6/17/2008 & 14.72 & 27,800 \\
\hline 73 & 05449500 & Iowa River near Rowan, Iowa & 429 & 06/1954 & 14.88 & 8,460 & $3 / 67$ & 6/9/2008 & 15.89 & 7,890 \\
\hline 74 & 05451080 & South Fork Iowa River near Blairsburg, Iowa & 12.0 & $03 / 2007$ & 11.79 & 227 & $1 / 3$ & 6/8/2008 & 12.50 & 762 \\
\hline 75 & 05451210 & South Fork Iowa River, New Providence, Iowa & 224 & 06/2007 & 10.68 & 3,910 & $1 / 13$ & 6/8/2008 & 13.84 & 7,390 \\
\hline 76 & 05451500 & Iowa River at Marshalltown, Iowa & 1,532 & $06 / 1918$ & ${ }^{d} 17.74$ & 42,000 & 3/92 & 6/13/2008 & 21.79 & 22,400 \\
\hline 77 & 05451700 & Timber Creek near Marshalltown, Iowa & 118 & 08/1977 & 17.69 & 12,000 & $5 / 60$ & $6 / 8 / 2008$ & 16.19 & 7,010 \\
\hline 78 & 05451955 & Stein Creek near Clutier, Iowa & 23.4 & $06 / 1982$ & 77.92 & 11,400 & $1 / 36$ & $5 / 30 / 2008$ & 78.02 & 12,200 \\
\hline 79 & 05452000 & Salt Creek near Elberon, Iowa & 201 & 07/1993 & 20.85 & 36,600 & $5 / 64$ & 5/30/2008 & 19.75 & 22,400 \\
\hline 80 & 05453100 & Iowa River at Marengo, Iowa & 2,794 & $07 / 1993$ & 20.31 & 38,000 & $1 / 52$ & 6/12/2008 & 21.38 & 51,000 \\
\hline 81 & 05453200 & Price Creek at Amana, Iowa & 29.1 & $06 / 1990$ & 88.78 & 5,080 & 9/43 & 6/12/2008 & 91.09 & 3,110 \\
\hline 82 & 05453520 & Iowa River below Coralville Dam, Coralville, Iowa & 3,115 & 07/1993 & 63.95 & 25,800 & $1 / 16$ & $6 / 15 / 2008$ & 68.09 & 39,900 \\
\hline 83 & 05454180 & Clear Creek Tributary near Williamsburg, Iowa & & 06/2007 & 49.18 & 328 & $1 / 19$ & 6/12/2008 & 49.37 & 346 \\
\hline 84 & 05454500 & Iowa River at Iowa City, Iowa & 3,271 & $06 / 1851$ & 24.10 & 70,000 & $4 / 108$ & 6/15/2008 & 31.53 & 41,100 \\
\hline 85 & 05455700 & Iowa River at Lone Tree, Iowa & 4,293 & 07/1993 & 22.94 & '57,100 & 2/52 & 6/15/2008 & 23.10 & 153,700 \\
\hline 86 & 05457000 & Cedar River near Austin, Minn. & 399 & $09 / 2004$ & 23.26 & 20,000 & $3 / 69$ & 6/12/2008 & 21.42 & 15,300 \\
\hline 87 & 05457440 & Deer Creek near Carpenter, Iowa & 91.6 & 07/2004 & 85.75 & 4,150 & $1 / 36$ & 6/8/2008 & 87.86 & 11,800 \\
\hline 88 & 05457700 & Cedar River at Charles City, Iowa & 1,054 & 07/1999 & 22.81 & 31,200 & $1 / 54$ & 6/9/2008 & 25.33 & 34,600 \\
\hline 89 & 05457778 & Little Cedar River near Johnsburg, Minn. & 45.8 & 08/1993 & 17.58 & 9,280 & 4/23 & 6/12/2008 & 16.04 & 3,710 \\
\hline 90 & 05458000 & Little Cedar River near Ionia, Iowa & 306 & $08 / 1993$ & 18.99 & 14,000 & $1 / 55$ & 6/9/2008 & 21.32 & 24,700 \\
\hline 91 & & & & 04/2001 & 12.95 & 25,600 & $1 / 8$ & 10/2008 & 19.33 & \\
\hline 92 & 438500 & Cedar River at Janesville, Iow & & 07/1999 & 17.15 & 42,200 & 1/88 & 6/10/2008 & 19.45 & 53,400 \\
\hline
\end{tabular}

\begin{tabular}{|c|c|c|c|c|c|c|c|c|c|c|c|c|}
\hline \multirow{4}{*}{$\begin{array}{l}\text { Estimated } \\
\text { AEF for } \\
\text { observed } \\
\text { peak } \\
\text { streantlow } \\
\text { (percent) }\end{array}$} & \multicolumn{12}{|c|}{ Expected peak streamfllows for selected AEP with 95-percent confidence limits $\left(\mathrm{ft}^{\mathrm{t}} / \mathbf{s}^{b}\right.$} \\
\hline & \multicolumn{3}{|c|}{$\begin{array}{c}\text { 4-percent AEP } \\
\text { (25-year recurrence) }\end{array}$} & \multicolumn{3}{|c|}{$\begin{array}{l}\text { 2-percent AEP } \\
\text { (50-year recurrence) }\end{array}$} & \multicolumn{3}{|c|}{$\begin{array}{c}\text { 1-percent AEP } \\
\text { (100-year recurrence) }\end{array}$} & \multicolumn{3}{|c|}{$\begin{array}{l}\text { 0.2-percent AEP } \\
\text { (500-year recurrence) }\end{array}$} \\
\hline & \multirow[b]{2}{*}{ Estimate } & \multicolumn{2}{|c|}{ Confidence limit } & \multirow[b]{2}{*}{ Estimate } & \multicolumn{2}{|c|}{ Confidence limit } & \multirow[b]{2}{*}{ Estimate } & \multicolumn{2}{|c|}{ Confidence limit } & \multirow{2}{*}{ Estimate } & \multicolumn{2}{|c|}{ Confidence limit } \\
\hline & & Low & High & & Low & High & & Low & High & & Low & High \\
\hline $0.2-1$ & 26,600 & -- & -- & 31,100 & -- & -- & 35,600 & -- & -- & i 46,300 & -- & -- \\
\hline $2-4$ & 18,100 & 14,300 & 23,000 & 22,100 & 17,100 & 28,600 & 26,100 & 19,700 & 34,500 & 36,100 & 25,500 & 51,200 \\
\hline $1-2$ & 35,100 & 30,500 & 40,400 & 41,100 & 35,000 & 48,300 & 47,300 & 39,300 & 56,900 & 62,300 & 48,800 & 79,600 \\
\hline $2-4$ & 14,700 & 10,800 & 19,900 & 17,800 & 12,500 & 25,500 & 20,900 & 13,800 & 31,800 & 23,900 & 14,000 & 40,800 \\
\hline $2-4$ & 7,240 & 5,820 & 9,010 & 9,000 & 7,050 & 11,500 & 10,900 & 8,300 & 14,300 & 15,800 & 11,300 & 22,300 \\
\hline $.2-1$ & 5,010 & 3,920 & 6,400 & 6,260 & 4,800 & 8,180 & 7,610 & 5,680 & 10,200 & 11,200 & 7,820 & 16,100 \\
\hline $2-4$ & ${ }^{81,110}$ & 616 & 2,820 & ${ }^{81,620}$ & 842 & 4,680 & ${ }^{82,280}$ & 1,120 & 7,460 & ${ }^{84,660}$ & 1,990 & 19,800 \\
\hline $.2-1$ & ${ }^{i} 15,000$ & -- & -- & ${ }^{i} 17,900$ & -- & -- & 20,700 & -- & -- & 27,800 & -- & -- \\
\hline $2-4$ & ${ }^{j} 19,200$ & 15,700 & 23,500 & 222,900 & 18,300 & 28,600 & 26,600 & 20,800 & 34,000 & 35,500 & 26,000 & 48,400 \\
\hline 4-10 & 12,200 & 10,000 & 14,800 & 14,300 & 11,300 & 18,000 & 16,400 & 12,600 & 21,500 & 22,000 & 15,400 & 31,500 \\
\hline $1-2$ & 14,500 & 11,100 & 19,000 & 17,300 & 13,000 & 22,900 & 20,000 & 14,800 & 27,100 & 26,900 & 18,600 & 38,900 \\
\hline $4-10$ & 23,900 & 20,000 & 28,400 & 28,800 & 23,600 & 35,000 & 33,700 & 27,000 & 42,000 & 45,400 & 34,100 & 60,300 \\
\hline $2-4$ & $k_{227,600}$ & -- & -- & $k_{33,100}$ & -- & -- & ${ }^{k} 38,500$ & -- & -- & ${ }^{k} 51,400$ & -- & -- \\
\hline $2-4$ & 31,700 & 26,600 & 37,800 & 37,700 & 31,000 & 45,900 & 43,700 & 35,100 & 54,500 & 57,800 & 43,600 & 76,700 \\
\hline $4-10$ & ${ }^{85,040}$ & 3,370 & 8,920 & ${ }^{86}, 690$ & 4,300 & 12,600 & ${ }^{88,600}$ & 5,330 & 17,200 & ${ }^{8} 14,200$ & 8,180 & 32,300 \\
\hline $4-10$ & 88,420 & 5,930 & 15,100 & ${ }^{8} 10,100$ & 6,870 & 19,400 & ${ }^{811,800}$ & 7,830 & 24,200 & 816,300 & 10,100 & 38,000 \\
\hline $.2-1$ & 1,450 & 1,060 & 1,980 & 1,710 & 1,190 & 2,450 & 1,960 & 1,310 & 2,940 & 2,980 & 2,080 & 4,910 \\
\hline $.2-1$ & 4,990 & 4,150 & & & 4,600 & 7,150 & 6,500 & 5,020 & 8,520 & 8,400 & 6,950 & 10,700 \\
\hline $.2-1$ & ${ }^{81,200}$ & 978 & 1,630 & ${ }^{81,390}$ & 1,110 & 1,970 & ${ }^{81,600}$ & 1,240 & 2,350 & ${ }^{82}, 130$ & 1,580 & 3,420 \\
\hline $.2-1$ & 4,950 & 4,220 & 5,810 & 5,600 & 4,620 & 6,780 & 6,230 & 4,970 & 7,810 & 7,550 & 6,370 & 9,370 \\
\hline$<.2$ & 652 & 538 & 865 & 757 & 611 & 1,050 & 869 & 686 & 1,250 & 1,160 & 873 & 1,810 \\
\hline $1-2$ & 12,300 & 9,800 & 15,500 & 14,100 & 10,800 & 18,600 & 16,000 & 11,700 & 22,000 & 18,600 & 14,800 & 26,000 \\
\hline $1-2$ & 2,360 & 1,520 & 3,670 & 2,990 & 1,800 & 4,960 & 3,660 & 2,060 & 6,510 & 4,900 & 2,910 & 11,200 \\
\hline $.2-1$ & 735 & 675 & 817 & 811 & 738 & 913 & 887 & 800 & 1,010 & 1,060 & 942 & 1,240 \\
\hline $.2-1$ & 12,500 & 11,000 & 14,200 & 13,900 & 11,900 & 16,100 & 15,200 & 12,800 & 18,200 & 18,000 & 14,100 & 22,900 \\
\hline $4-10$ & 29,400 & 25,600 & 33,700 & 32,700 & 27,900 & 38,500 & 36,100 & 29,900 & 43,500 & 43,600 & 33,800 & 56,300 \\
\hline $1-2$ & 6,390 & 5,140 & 7,950 & 7,560 & 5,900 & 9,690 & 8,750 & 6,620 & 11,600 & 11,600 & 8,160 & 16,400 \\
\hline $.2-1$ & $i 545$ & -- & -- & ${ }^{1644}$ & - & -- & ${ }^{i} 743$ & -- & -- & i982 & -- & -- \\
\hline $2-4$ & 7,170 & 5,500 & 9,350 & 8,680 & 6,540 & 11,500 & 10,200 & 7,490 & 13,800 & 13,800 & 9,500 & 20,000 \\
\hline $2-4$ & 22,300 & 19,300 & 25,800 & 25,900 & 21,900 & 30,600 & 29,400 & 24,300 & 35,600 & 37,600 & 29,200 & 48,400 \\
\hline $4-10$ & 8,930 & 7,250 & 11,000 & 10,900 & 8,680 & 13,700 & 13,000 & 10,100 & 16,700 & 18,000 & 13,100 & 24,700 \\
\hline$<.2$ & 4,870 & 3,790 & 6,250 & 5,990 & 4,570 & 7,850 & 7,180 & 5,350 & 9,630 & 10,400 & 7,220 & 14,900 \\
\hline .2-1 & 15,200 & 12,000 & 19,3 & 18,200 & 14,100 & 23,500 & 21,300 & 16,100 & 28,200 & 29,300 & 20,700 & 41,500 \\
\hline $.2-1$ & 32,000 & 26,600 & 38,500 & 37,200 & 30,200 & 45,700 & 42,300 & 33,700 & 53,200 & 54,300 & 40,500 & 72,600 \\
\hline$>10$ & 4,320 & 3,540 & 5,270 & 5,090 & 4,050 & 6,390 & 5,900 & 4,560 & 7,630 & 7,960 & 5,690 & 11,100 \\
\hline $.2-1$ & 11,600 & -- & -- & $\mathrm{m}_{22,200}$ & -- & -- & $\mathrm{m} 28,600$ & - & -- & $\mathrm{m}_{44,400}$ & -- & -- \\
\hline 4-10 & 8559 & 269 & 1,740 & ${ }^{8} 852$ & 383 & 3,040 & ${ }^{81,240}$ & 523 & 5,020 & ${ }^{82,640}$ & 970 & 13,800 \\
\hline $.2-1$ & ${ }^{\mathrm{m}} 13,100$ & -- & -- & $\mathrm{m}_{23,800}$ & -- & -- & ${ }^{\mathrm{m}} 30,000$ & -- & -- & ${ }^{\mathrm{m}} 45,300$ & -- & -- \\
\hline $.2-1$ & ${ }^{\mathrm{m}} 30,200$ & -- & -- & $\mathrm{m}_{3}^{3} 3,100$ & -- & -- & $\mathrm{m}_{53,400}$ & -- & -- & ${ }^{\mathrm{m}} 76,100$ & -- & -- \\
\hline $1-2$ & 12,200 & 9,940 & 15,000 & 14,300 & 11,200 & 18,100 & 16,300 & 12,300 & 21,500 & 21,000 & 14,400 & 30,600 \\
\hline$<.2$ & 5,570 & 4,480 & 6,930 & 6,840 & 5,380 & 8,680 & 8,140 & 6,260 & 10,600 & 11,400 & 8,210 & 15,800 \\
\hline $.2-1$ & 25,100 & 21,200 & 29,800 & 28,900 & 23,800 & 35,000 & 32,500 & 26,200 & 40,400 & 41,000 & 31,100 & 54,200 \\
\hline $4-10$ & 4,950 & 3,400 & 7,200 & 6,000 & 4,000 & 8,980 & 7,240 & 4,600 & 11,400 & 10,400 & 5,900 & 18,500 \\
\hline $.2-1$ & 14,100 & 11,200 & 17,600 & 17,100 & 13,400 & 21,800 & 20,100 & 15,400 & 26,200 & 27,400 & 19,700 & 38,200 \\
\hline$<.2$ & '30,400 & -- & -- & ${ }^{\circ} 35,400$ & -- & -- & ${ }^{\circ} 40,300$ & -- & -- & ${ }^{\circ 51,800}$ & -- & -- \\
\hline .2-1 & 31,700 & 26,800 & 37,400 & 36,900 & 30,600 & 44,600 & 42,000 & 33,900 & 51,900 & 53,900 & 40,800 & 71,000 \\
\hline
\end{tabular}


Table 5. Summary of peak stages, streamflows, and flood-probability estimates for selected U.S. Geological Survey streamgages during May and June 2008. - Continued

[mi², square mile; ft, foot; fi³s, cubic foot per second; AEP, annual exceedance probability; $>$, greater than; $<$, less than; ;-, no data; R., River]

\begin{tabular}{|c|c|c|c|c|c|c|c|c|c|c|}
\hline \multirow{3}{*}{$\begin{array}{c}\text { Site } \\
\text { number } \\
\text { (fig. 12) }\end{array}$} & \multirow{3}{*}{$\begin{array}{l}\text { Station } \\
\text { number }\end{array}$} & \multirow{3}{*}{ Station nam } & \multirow{3}{*}{$\begin{array}{c}\text { Contributing } \\
\text { drainage } \\
\text { area } \\
\left(\mathrm{mi}^{2}\right)\end{array}$} & \multicolumn{7}{|c|}{ Flood data } \\
\hline & & & & \multicolumn{3}{|r|}{ um streamflow } & \multicolumn{4}{|c|}{ Flood of June 2008} \\
\hline & & & & Date & $\begin{array}{c}\begin{array}{c}\text { Stage } \\
\text { (tt) }\end{array} \\
\text { (a) }\end{array}$ & $\begin{array}{c}\text { Streamflow } \\
\left(\mathrm{ft}^{\prime} / \mathbf{s}\right)\end{array}$ & $\begin{array}{l}\text { Ranka/ } \\
\text { annual } \\
\text { peaks }\end{array}$ & Date & $\begin{array}{l}\begin{array}{c}\text { Peak } \\
\text { stage } \\
\text { (ft) }\end{array}\end{array}$ & $\begin{array}{c}\text { Peak } \\
\text { streamflow } \\
\left(\mathrm{tt}^{3} / \mathrm{s}\right)\end{array}$ \\
\hline 93 & 05458900 & West Fork Cedar River at Finchford, Iowa & 846 & $06 / 1951$ & 17.28 & 31,900 & $2 / 64$ & $6 / 10 / 2008$ & 20.82 & \\
\hline 94 & 05459490 & Spring Creek near Mason City, Iowa & 29.3 & 05/2004 & 91.15 & 5,340 & $2 / 43$ & 6/6/2008 & 92.91 & 4,680 \\
\hline 95 & 05459500 & Winnebago River at Mason City, Iowa & 526 & $03 / 1933$ & 15.70 & 10,800 & $1 / 76$ & 6/8/2008 & 18.74 & 13,100 \\
\hline 96 & 05460100 & Willow Creek near Mason City, Iowa & 78.6 & 05/2004 & 92.21 & 1,270 & $1 / 42$ & $6 / 8 / 2008$ & 93.28 & 2,380 \\
\hline 97 & 05462000 & Shell Rock River at Shell Rock, Iowa & 1,746 & 1856 & 17.70 & ${ }^{\mathrm{n}} 45,000$ & $1 / 56$ & 6/10/2008 & 20.36 & 60,400 \\
\hline 98 & 05463000 & Beaver Creek at New Hartford, Iowa & 347 & 06/1947 & 13.50 & 18,000 & $1 / 63$ & $6 / 8 / 2008$ & 15.71 & 25,900 \\
\hline 99 & 05463500 & Black Hawk Creek at Hudson, Iowa & 303 & 07/1969 & 18.23 & 19,300 & $\left({ }^{(p)}\right.$ & 6/13/2008 & 17.47 & 11,800 \\
\hline 100 & 05464000 & Cedar River at Waterloo, Iowa & 5,146 & $03 / 1961$ & 21.86 & 76,700 & $1 / 70$ & $6 / 11 / 2008$ & 27.01 & 112,000 \\
\hline 101 & & & 299 & & 17.39 & & & & & 15,700 \\
\hline 102 & 05464500 & Cedar River at Cedar Rapids, Iowa & 6,510 & $03 / 1961$ & ${ }^{9} 19.66$ & 73,000 & $1 / 107$ & $6 / 13 / 2008$ & 31.12 & 140,000 \\
\hline 103 & 05465000 & Cedar River near Conesville, Iowa & 7,787 & 04/1993 & 17.11 & 74,000 & $1 / 69$ & 6/14/2008 & $\mathrm{d} 23.37$ & 127,000 \\
\hline 104 & 05465150 & & 30.2 & & 90.66 & & $3 / 45$ & 6/13/2008 & 91.19 & 4,220 \\
\hline 105 & 05465500 & Iowa River at Wapello, Iowa & 12,500 & 07/1993 & 28.10 & $' 111,000$ & $1 / 106$ & 6/14/2008 & 32.15 & '188,000 \\
\hline 106 & 05469860 & Mud Lake Drainage Ditch 71 at Jewell, Iowa & 65.4 & 07/1993 & 91.32 & 3,700 & $2 / 43$ & 6/8/2008 & 91.87 & 3,120 \\
\hline 107 & & South Skunk River near Ames, Iowa & & 06/1996 & $\mathrm{d} 15.89$ & & $3 / 84$ & 6/9/2008 & 16.93 & \\
\hline 108 & 05470500 & Squaw Creek at Ames, Iowa & 204 & 07/1993 & 18.54 & 24,300 & $3 / 53$ & $5 / 30 / 2008$ & 15.85 & 12,600 \\
\hline 109 & 05471000 & S. Skunk River below Squaw Creek near Ames, Iowa & 556 & 07/1993 & $\mathrm{d}_{25.53}$ & 26,500 & $3 / 46$ & $5 / 30 / 2008$ & 24.70 & 19,800 \\
\hline 110 & 05471050 & South Skunk River at Colfax, Iowa & 803 & 07/1993 & 21.53 & & $2 / 23$ & 6/14/2008 & 20.25 & 10,900 \\
\hline 111 & & & & & & & & & 33 & \\
\hline 112 & 05471500 & South Skunk River near Oskaloosa, Iowa & 1,635 & $05 / 1944$ & 25.80 & 37,000 & 4/64 & 6/12/2008 & 24.61 & 17,300 \\
\hline 113 & 05474000 & Skunk River at Augusta, Iowa & & $/ 1973$ & 27.05 & & 9/96 & 6/16/2008 & 22.85 & 43,900 \\
\hline 114 & & & & & 27.58 & & $2 / 132$ & & -- & \\
\hline 115 & 05479000 & East Fork Des Moines River at Dakota City, Iowa & 1,308 & $09 / 1938$ & 17.40 & $\mathrm{~h}_{22,000}$ & $10 / 72$ & 6/14/2008 & 19.09 & 10,400 \\
\hline 116 & 05480500 & Des Moines River at Fort Dodge, Iowa & & & 17.79 & 35,600 & 3/78 & 6/8/2008 & 15.73 & 34,400 \\
\hline 117 & & & & & 93.59 & & & & 85 & \\
\hline 118 & 05481000 & Boone River near Webster City, Iowa & 844 & 06/1918 & 19.10 & 21,500 & $2 / 70$ & 6/10/2008 & 17.74 & 20,500 \\
\hline 119 & 05481300 & Des Moine & & & 25.68 & & $1 / 41$ & & 132 & \\
\hline 120 & 481650 & Des 1 & & & 24.50 & & $2 / 47$ & 6/13/2008 & 1.03 & 50,500 \\
\hline 121 & 05481950 & Beaver Crec & 358 & 1993 & 16.58 & & $3 / 49$ & 1/2008 & 14.51 & 7,800 \\
\hline 122 & 05482 & Des Moines & & & 30.16 & & $2 / 62$ & 2008 & đ31.50 & 147,300 \\
\hline 123 & 05482500 & Nort & & & 22.30 & & $5 / 69$ & 1/2008 & 18.41 & 18,300 \\
\hline 124 & & & & & 13.97 & & $1 / 57$ & 008 & 13.40 & \\
\hline 125 & 0548 & Sout & 994 & & 26.98 & 44,00 & $\left({ }^{(p)}\right.$ & & .80 & 26,300 \\
\hline 126 & 05484500 & Raccoon River at Van Meter, Iowa & & & 26.34 & & 3/94 & 6/12/2008 & 22.67 & 3,500 \\
\hline 127 & & & & & ‘40.77 & & $2 / 15$ & & 31 & \\
\hline 128 & & & & & 26.80 & & $2 / 22$ & & .66 & \\
\hline 129 & 05485500 & Des Moine & 9,879 & 07/1993 & $\mathrm{d}_{34.29}$ & $' 116,000$ & $2 / 68$ & 6/13/2008 & 5.55 & '104,000 \\
\hline 130 & 05485640 & Fourn & 92.7 & 06/1998 & 15.00 & & & 6/6/2008 & 15.14 & \\
\hline 131 & & & 349 & & & & & & 91 & \\
\hline 132 & & Middle River near Indianola, Iowa & 489 & & 26.40 & 34,000 & $2 / 69$ & 008 & .55 & 19,000 \\
\hline 133 & 05487500 & & & 07/1993 & 82.88 & & $3 / 23$ & 6/14/2008 & 79.28 & \\
\hline 134 & & & & & & & & & 108. & \\
\hline 135 & & Des Moines River near Tracy, Iowa & 12,479 & & 26.50 & 155,000 & $4 / 90$ & 6/14/2008 & 23.70 & 104,000 \\
\hline 136 & 05489500 & 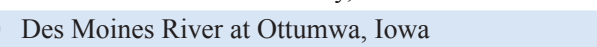 & 13,374 & $06 / 1903$ & ${ }^{d} 19.40$ & ${ }^{\mathrm{h}} 140,000$ & 4/94 & 6/17/2008 & 20.60 & ${ }^{\prime} 102,000$ \\
\hline 20 & & & & & & & & & & \\
\hline & & & & & & & & & & \\
\hline
\end{tabular}

\begin{tabular}{|c|c|c|c|c|c|c|c|c|c|c|c|c|}
\hline \multirow{4}{*}{$\begin{array}{c}\text { Estimated } \\
\text { AEP for } \\
\text { observed } \\
\text { peak } \\
\text { streamflow } \\
\text { (percent) }\end{array}$} & \multicolumn{12}{|c|}{ Expected peak streamflows for selected AEP with 95-percent confidence limits $\left(\mathrm{ft}^{\mathrm{t}} / \mathrm{s}\right)^{b}$} \\
\hline & \multicolumn{3}{|c|}{$\begin{array}{l}\text { 4-percent AEP } \\
\text { (25-year recurrence) }\end{array}$} & \multicolumn{3}{|c|}{$\begin{array}{l}\text { 2-percent AEP } \\
\text { (50-year recurrence) }\end{array}$} & \multicolumn{3}{|c|}{$\begin{array}{c}\text { 1-percent AEP } \\
\text { (100-year recurrence) } \\
\end{array}$} & \multicolumn{3}{|c|}{$\begin{array}{l}\text { 0.2-percent AEP } \\
\text { (500-year recurrence) }\end{array}$} \\
\hline & \multirow{2}{*}{ Estimate } & \multicolumn{2}{|c|}{ Confidence limit } & \multirow{2}{*}{ Estimate } & \multicolumn{2}{|c|}{ Confidence limit } & \multirow{2}{*}{ Estimate } & \multicolumn{2}{|c|}{ Confidence limit } & \multirow{2}{*}{ Estimate } & \multicolumn{2}{|c|}{ Confidence limit } \\
\hline & & Low & High & & Low & High & & Low & High & & Low & High \\
\hline $2-4$ & 22,300 & 18,200 & 27,200 & 26,400 & 21,100 & 32,900 & 30,400 & 23,800 & 38,900 & 39,800 & 29,100 & 54,500 \\
\hline $1-2$ & 3,300 & 2,330 & 4,680 & 4,040 & 2,780 & 5,860 & 4,750 & 3,200 & 7,060 & 6,500 & 4,160 & 10,200 \\
\hline $.2-1$ & 9,020 & 7,360 & 11,000 & 10,500 & 8,340 & 13,300 & 12,000 & 9,250 & 15,600 & 15,600 & 11,200 & 21,700 \\
\hline $.2-1$ & 1,500 & 1,230 & 1,840 & 1,750 & 1,390 & 2,210 & 2,020 & 1,560 & 2,610 & 2,680 & 1,940 & 3,720 \\
\hline$<.2$ & 29,600 & 25,400 & 34,500 & 34,900 & 29,200 & 41,600 & 40,000 & 32,700 & 49,000 & 51,900 & 39,800 & 67,700 \\
\hline $.2-1$ & 16,400 & 13,300 & 20,300 & 19,600 & 15,500 & 24,700 & 22,800 & 17,700 & 29,500 & 30,500 & 22,100 & 42,100 \\
\hline $4-10$ & 15,100 & 11,900 & 19,000 & 18,300 & 14,200 & 23,600 & 21,600 & 16,400 & 28,400 & 29,700 & 21,100 & 41,600 \\
\hline $.2-1$ & 877,100 & 62,400 & 100,000 & 891,200 & 72,600 & 121,000 & 8105,000 & 82,600 & 143,000 & ${ }^{8} 137,000$ & 105,000 & 193,000 \\
\hline $2-4$ & 13,300 & 10,100 & 17,600 & 15,900 & 11,900 & 21,300 & 18,500 & 13,500 & 25,200 & 24,900 & 17,100 & 36,300 \\
\hline$<.2$ & 870,300 & 60,500 & 84,000 & 882,200 & 69,900 & 99,800 & 894,100 & 79,200 & 116,000 & $8_{122,000}$ & 100,000 & 154,000 \\
\hline $.2-1$ & 876,400 & 64,000 & 95,100 & 888,600 & 73,200 & 113,000 & :101,000 & 82,200 & 130,000 & ${ }^{8} 128,000$ & 102,000 & 171,000 \\
\hline 4-10 & 4,300 & 3,360 & 5,510 & 5,330 & 4,080 & 6,960 & 6,400 & 4,780 & 8,560 & 9,180 & 6,410 & 13,100 \\
\hline$<.2$ & m86,100 & -- & -- & "'121,000 & -- & -- & ${ }^{m} 140,000$ & -- & -- & m185,000 & -- & -- \\
\hline $1-2$ & 2,430 & 1,900 & 3,110 & 2,790 & 2,110 & 3,680 & 3,130 & 2,300 & 4,270 & 3,920 & 2,680 & 5,730 \\
\hline $1-2$ & 8,840 & 7,520 & 10,400 & 10,600 & 8,770 & 12,700 & 12,300 & 9,970 & 15,200 & 16,500 & 12,600 & 21,800 \\
\hline $1-2$ & 9,300 & 7,560 & 11,400 & 11,500 & 9,070 & 14,500 & 13,600 & 10,500 & 17,700 & 19,400 & 13,900 & 27,100 \\
\hline $.2-1$ & 14,200 & 12,100 & 16,600 & 16,700 & 13,900 & 20,000 & 19,200 & 15,600 & 23,600 & 25,400 & 19,400 & 33,300 \\
\hline 4-10 & 14,200 & 11,500 & 17,600 & 16,700 & 13,200 & 21,200 & 19,300 & 14,900 & 24,900 & 25,200 & 18,300 & 34,800 \\
\hline $4-10$ & 11,100 & 9,030 & 13,600 & & 10,500 & 16,600 & 15,300 & & 19,800 & 20,800 & 15,000 & 28,800 \\
\hline 4-10 & 20,400 & 17,600 & 23,700 & 23,800 & 20,100 & 28,300 & 27,300 & 22,500 & 33,200 & 35,600 & 27,600 & 45,700 \\
\hline 4-10 & 44,800 & 40,300 & 49,700 & 50,300 & 44,500 & 56,900 & 55,700 & 48,200 & 64,300 & 67,800 & 55,700 & 82,400 \\
\hline$<.2$ & 298,000 & -- & -- & 331,000 & -- & -- & 366,000 & -- & -- & 4429,000 & -- & -- \\
\hline $4-10$ & 13,900 & 11,000 & 17,600 & 16,600 & 12,700 & 21,600 & 19,300 & 14,300 & 26,000 & 25,800 & 17,800 & 37,400 \\
\hline $2-4$ & 30,500 & 25,600 & 36,300 & 35,800 & 29,200 & 44,000 & 41,300 & 32,600 & 52,300 & 54,600 & 40,100 & 74,500 \\
\hline $1-2$ & 1,140 & 738 & 1,760 & 1,350 & 836 & 2,170 & 1,530 & 907 & 2,590 & 1,910 & 1,020 & 3,580 \\
\hline $.2-1$ & 15,300 & 12,900 & 18,200 & 17,700 & 14,400 & 21,600 & 19,900 & 15,800 & 25,100 & 25,200 & 18,600 & 34,000 \\
\hline $1-2$ & 441,500 & 34,900 & 49,300 & ${ }^{4} 48,300$ & 39,500 & 59,200 & is5,200 & 43,700 & 69,800 & ${ }^{3} 71,700$ & 52,700 & 97,600 \\
\hline$<.2$ & -- & -- & -- & "27,000 & -- & -- & "34,000 & -- & -- & ${ }^{n 50,000}$ & -- & -- \\
\hline 4-10 & 9,490 & 7,610 & 11,800 & 11,500 & 9,000 & 14,600 & 13,600 & 10,400 & 17,700 & 18,600 & 13,200 & 26,000 \\
\hline $.2-1$ & - & - & -- & ${ }^{\mathrm{n}} 30,000$ & - & -- & ${ }^{\mathrm{n} 37,000}$ & - & - & ${ }^{\mathrm{n} 52,000}$ & - & -- \\
\hline $4-10$ & 21,500 & 17,900 & 25,800 & 24,700 & 20,100 & 30,400 & 27,900 & 22,100 & 35,300 & 35,100 & 26,000 & 47,500 \\
\hline $1-2$ & 2,520 & 1,940 & 3,280 & 3,030 & 2,260 & 4,070 & 3,540 & 2,560 & 4,900 & 4,740 & 3,190 & 7,060 \\
\hline 4-10 & 27,400 & 22,900 & 32,800 & 31,600 & 25,900 & 38,600 & 35,800 & 28,600 & 44,800 & 45,900 & 34,400 & 61,100 \\
\hline $2-4$ & 39,200 & 33,200 & 46,300 & 45,300 & 37,500 & 54,700 & 51,500 & 41,600 & 63,700 & 65,900 & 49,900 & 87,000 \\
\hline $1-2$ & 43,500 & 37,000 & 51,100 & 49,700 & 41,300 & 59,700 & 55,500 & 45,100 & 68,400 & 69,400 & 52,800 & 91,100 \\
\hline $1-2$ & 47,300 & 40,200 & 55,800 & 53,600 & 44,400 & 64,600 & 59,400 & 48,000 & 73,500 & 73,200 & 55,400 & 96,600 \\
\hline .2-1 & r.- & -- & -- & "72,000 & -- & -- & "87,000 & -- & -- & ${ }^{\mathrm{n} 132,000}$ & -- & -- \\
\hline $2-4$ & 6,140 & 4,880 & 7,730 & 7,330 & 5,690 & 9,440 & 8,580 & 6,500 & 11,300 & 11,800 & 8,310 & 16,600 \\
\hline 4-10 & 16,200 & 13,000 & 20,200 & 20,000 & 15,700 & 25,400 & 23,700 & 18,200 & 30,900 & 33,000 & 23,800 & 45,900 \\
\hline $2-4$ & 18,400 & 15,700 & 21,600 & 21,300 & 17,800 & 25,500 & 24,100 & 19,700 & 29,600 & 30,700 & 23,600 & 40,100 \\
\hline s-- & -- & -- & -- & -- & -- & -- & -- & -- & -- & -- & -- & -- \\
\hline s-- & -- & -- & -- & & -- & -- & - & -- & -- & -- & -- & \\
\hline $.2-1$ & -- & -- & -- & ${ }^{\mathrm{n} 51,000}$ & -- & -- & ${ }^{\mathrm{n} 70,000}$ & -- & -- & ${ }^{\mathrm{n}} 135,000$ & -- & -- \\
\hline .2-1 & -- & -- & -- & ${ }^{n} 61,000$ & -- & -- & "81,000 & -- & -- & ${ }^{n} 144,000$ & -- & -- \\
\hline $.2-1$ & -- & -- & -- & ${ }^{n} 66,000$ & $\ldots$ & $\ldots$ & "86,000 & & 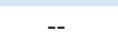 & ${ }^{n} 149,000$ & & 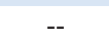 \\
\hline $4-10$ & $19,30 \mathrm{c}$ & 16,200 & 23,000 & 22,600 & 18,300 & 27,900 & 26,000 & 20,300 & 33,300 & 34,100 & 24,400 & 7,800 \\
\hline
\end{tabular}


Table 5. Summary of peak stages, streamflows, and flood-probability estimates for selected U.S. Geological Survey streamgages during May and June 2008. - Continued

[mi², square mile; ft, foot; fi³s, cubic foot per second; AEP, annual exceedance probability; $>$, greater than; $<$, less than; ;-, no data; R., River]

\begin{tabular}{|c|c|c|c|c|c|c|c|c|c|c|}
\hline \multirow{3}{*}{$\begin{array}{c}\text { Site } \\
\text { number } \\
\text { (fig. 12) }\end{array}$} & \multirow{3}{*}{$\begin{array}{l}\text { Station } \\
\text { number }\end{array}$} & \multirow{3}{*}{ Station name } & \multirow{3}{*}{$\begin{array}{l}\text { Contributing } \\
\text { drainage } \\
\text { area } \\
\left(\mathrm{mi}^{2}\right)\end{array}$} & \multicolumn{7}{|c|}{ Flood data } \\
\hline & & & & \multicolumn{3}{|c|}{ Previous maximum streamflow } & \multicolumn{4}{|c|}{ Flood of June 2008} \\
\hline & & & & Date & $\begin{array}{c}\text { Stage } \\
(\mathrm{tt})\end{array}$ & $\begin{array}{c}\text { Streamtlow } \\
(t \mathrm{t} / \mathrm{s})\end{array}$ & $\begin{array}{l}\text { Ranka/ } \\
\text { annual } \\
\text { peaks }\end{array}$ & Date & $\begin{array}{l}\begin{array}{c}\text { Peak } \\
\text { stage } \\
\text { (ft) }\end{array}\end{array}$ & $\begin{array}{c}\text { Peak } \\
\text { streamflow } \\
\left(\mathrm{tt}^{3} / \mathrm{s}\right)\end{array}$ \\
\hline 139 & 05527800 & Des Plaines River at Russell, IIll. & 123 & $05 / 2004$ & 11.09 & 3,500 & $5 / 49$ & $6 / 11 / 2008$ & 9.47 & 1,910 \\
\hline 140 & 05543830 & Fox River at Waukesha, Wis. & 126 & $04 / 1960$ & 8.00 & 2,500 & $2 / 47$ & 6/9/2008 & 8.85 & 2,440 \\
\hline 141 & 05544200 & Mukwonago River at Mukwonago, Wis. & 74.1 & 08/2007 & 3.96 & 317 & $1 / 33$ & 6/13/2008 & 4.95 & ${ }^{3} 364$ \\
\hline 142 & 05545750 & Fox River near New Munster, Wis. & 811 & $03 / 1960$ & 9.25 & 7,520 & $3 / 69$ & $6 / 15 / 2008$ & ‘5.18 & 5,960 \\
\hline 143 & 05572000 & Sangamon River at Monticello, Ill. & 550 & $10 / 1926$ & 18.50 & 19,000 & 7/100 & 6/4/2008 & 18.79 & 13,300 \\
\hline 144 & 05580000 & Kickapoo Creek at Waynesville, III. & 227 & $08 / 1981$ & 16.91 & 24,600 & $8 / 61$ & 6/4/2008 & 16.50 & 11,600 \\
\hline 145 & 05586100 & Illinois River at Valley City, Ill. & 26,743 & $05 / 1943$ & 28.61 & ${ }^{\circ} 123,000$ & $\left({ }^{(p)}\right.$ & $6 / 14 / 2008$ & 17.72 & ${ }^{6} 63,000$ \\
\hline 146 & 05587450 & Mississippi River at Grafton, IIl. & 171,300 & $08 / 1993$ & 38.17 & 1598,000 & $2 / 23$ & $6 / 28 / 2008$ & 30.80 & 1440,000 \\
\hline 147 & 05590800 & Lake Fork at Atwood, Ill. & 149 & $03 / 1979$ & 14.03 & 4,030 & $1 / 36$ & & 15.75 & 3,550 \\
\hline 148 & 05591200 & Kaskaskia River at Cooks Mills, IIl. & 473 & 05/2002 & 17.85 & 11,000 & $1 / 38$ & 6/7/2008 & 20.41 & 14,100 \\
\hline 149 & 05591700 & West Okaw River near Lovington, IIl. & 112 & $05 / 1996$ & 16.40 & 10,300 & $2 / 29$ & 6/7/2008 & 16.17 & 9,370 \\
\hline 150 & 06359500 & oreau River near Faith, S. Dak. & 2,660 & $04 / 1944$ & 21.90 & & 4/65 & 6/7/2008 & 21.50 & 22,900 \\
\hline 151 & 06360500 & Moreau River near Whitehorse, S. Dak. & 4,880 & 03/1997 & 26.93 & 29,700 & $4 / 55$ & 8/2008 & 25.56 & 25,000 \\
\hline 152 & 06425100 & Elk Creek near Rapid City, S. Dak. & 190 & $05 / 1996$ & 12.77 & 3,120 & $3 / 30$ & 6/6/2008 & 11.64 & 2,390 \\
\hline 153 & 06425500 & Elk Creek near Elm Springs, S. Dak. & 540 & $03 / 1952$ & 10.61 & & $4 / 59$ & 6/6/2008 & & 7,000 \\
\hline 154 & 06428500 & Belle Fourche R. at Wyo./S. Dak. State Line, S. Dak. & 3,280 & $05 / 1995$ & 16.33 & 16,320 & $2 / 62$ & 6/2008 & 15.98 & 15,190 \\
\hline 155 & 06433500 & Hay Creek at Belle Fourche, S. Dak. & 121 & $05 / 1995$ & 10.23 & 1,280 & $1 / 44$ & 6/6/2008 & 10.50 & ${ }^{\mathrm{n}} 1,400$ \\
\hline 156 & 06436000 & Belle Fourche River near Frui & 4,540 & $05 / 1982$ & 14.32 & $' 12,70$ & 4/63 & 6/6/2008 & 12.95 & 18,700 \\
\hline 157 & & & 102 & & 5.72 & & $1 / 26$ & & 7.29 & \\
\hline 158 & 06436760 & Horse Creek above Vale, S. Dak. & 464 & $05 / 1982$ & 24.80 & ${ }^{\circ} 17,700$ & $2 / 28$ & 6/6/2008 & 23.42 & ${ }^{\prime} 15,100$ \\
\hline 159 & 06437000 & Belle Fourche River near Sturgis, S. Dak. & 5,870 & $05 / 1982$ & 19.10 & 36,400 & $2 / 63$ & 6/6/2008 & 20.10 & 36,100 \\
\hline 160 & & & & & 15.90 & & $1 / 81$ & & 1.73 & \\
\hline 161 & 06438500 & Cheyenne River near Plainview, S. Dak. & 21,600 & $05 / 1996$ & 22.10 & 169,700 & $1 / 47$ & 6/7/2008 & 22.63 & 773,200 \\
\hline 162 & 06452000 & White River near Oacoma, S. Dak. & 9,940 & $03 / 1952$ & 19.40 & 51,900 & $5 / 80$ & 6/5/2008 & 19.39 & 33,800 \\
\hline 163 & 06465500 & & .580 & & ¿10.10 & & $5 / 53$ & & 5.56 & 00 \\
\hline 164 & 06606837 & (0660683710) Halfway Creek at Schaller, Iowa & 1.7 & 05/2007 & 94.64 & 486 & $1 / 19$ & 6/8/2008 & 97.31 & 1,010 \\
\hline 165 & 06609500 & Boyer River at Logan, Iowa & 871 & & 22.54 & 30,800 & $1 / 80$ & & $\mathrm{~d}_{24.75}$ & 33,600 \\
\hline 166 & 06610581 & Mosquito & 3.2 & 2004 & 87.50 & 1,96 & $2 / 18$ & 6/8/2008 & 85.24 & 1,360 \\
\hline 167 & 06768000 & Platte River near Overton, Nebr. & 51,620 & 1935 & ${ }^{8} 6.25$ & & 22/91 & $5 / 25 / 2008$ & 9.05 & $' 11,200$ \\
\hline 168 & 06794000 & Beaver Creek at Genoa & 429 & $/ 1950$ & ${ }^{d} 18.70$ & 21,200 & $6 / 68$ & $5 / 30 / 2008$ & 18.15 & 7,270 \\
\hline 169 & 06795500 & rell Crer & 294 & 1990 & 22.76 & 8,0 & $1 / 60$ & $5 / 30 / 2008$ & 22.06 & 11,200 \\
\hline 170 & & & & & d19.23 & $130, \mathrm{C}$ & $5 / 45$ & $5 / 31 / 2008$ & 21.06 & 185,600 \\
\hline 171 & 06805500 & & 71,000 & & ${ }^{\mathrm{d}} 11.90$ & 160,000 & $8 / 56$ & & 10.48 & 196,600 \\
\hline 172 & 06809500 & East Nishnabotna River at Red Oak, Iowa & 894 & /1998 & 29.39 & 60,500 & $6 / 82$ & 6/13/2008 & 24.09 & 27,000 \\
\hline 173 & 06811760 & & 10.7 & 998 & 14.68 & & $3 / 57$ & 5/2008 & 3.20 & \\
\hline 174 & & & 4,900 & & 25.60 & 358, & $8 / 59$ & & 198 & ${ }^{9} 167,000$ \\
\hline 175 & 06816290 & West Noda & 23.4 & $02 / 1973$ & 82.39 & & $1 / 43$ & 6/12/2008 & 80.54 & 4,850 \\
\hline 176 & 06817000 & & 762 & 2007 & 23.82 & & $1 / 81$ & $6 / 5 / 2008$ & .61 & \\
\hline 177 & & & & & & & $2 / 26$ & & .90 & \\
\hline 178 & & Missouri River at St. Joseph, & 420,100 & 1952 & 26.82 & 397,000 & $21 / 89$ & 6/13/2008 & 25.10 & ${ }^{\circ} 171,000$ \\
\hline 179 & 06819500 & 102 River at Maryville, Mo. & 515 & $/ 1973$ & 19.25 & 28,000 & $3 / 67$ & 6/6/2008 & 26.20 & 21,800 \\
\hline 180 & & & & & & & & & & \\
\hline 181 & & Republican River near Orleans, No & 8,880 & & 14.00 & 145,000 & 6/62 & $5 / 26 / 2008$ & 13.14 & 9,680 \\
\hline 182 & & Bow Creek near Stockton, Kans. & 341 & $07 / 1951$ & 13.60 & 12,900 & $5 / 58$ & $5 / 24 / 2008$ & 13.31 & 6,090 \\
\hline & & & & & & & & & & \\
\hline & & & & & & & & & & \\
\hline
\end{tabular}

\begin{tabular}{|c|c|c|c|c|c|c|c|c|c|c|c|c|}
\hline \multirow{4}{*}{$\begin{array}{c}\text { Estimated } \\
\text { AEP for } \\
\text { observed } \\
\text { peak } \\
\text { streamflow } \\
\text { (percent) }\end{array}$} & \multicolumn{12}{|c|}{ Expected peak streamfllows for selected AEP with 95-percent confidence limits $\left(\mathrm{ft}^{\mathrm{t}} / \mathrm{s}^{b}\right.$} \\
\hline & \multicolumn{3}{|c|}{$\begin{array}{c}\text { 4-percent AEP } \\
\text { (25-year recurrence) }\end{array}$} & \multicolumn{3}{|c|}{$\begin{array}{c}\text { 2-percent AEP } \\
\text { (50-year recurrence) }\end{array}$} & \multicolumn{3}{|c|}{$\begin{array}{c}\text { 1-percent AEP } \\
\text { (100-year recurrence) }\end{array}$} & \multicolumn{3}{|c|}{$\begin{array}{l}\text { 0.2-percent AEP } \\
\text { (500-year recurrence) }\end{array}$} \\
\hline & \multirow[b]{2}{*}{ Estimate } & \multicolumn{2}{|c|}{ Confidence limit } & \multirow{2}{*}{ Estimate } & \multicolumn{2}{|c|}{ Confidence limit } & \multirow{2}{*}{ Estimate } & \multicolumn{2}{|c|}{ Confidence limit } & \multirow{2}{*}{ Estimate } & \multicolumn{2}{|c|}{ Confidence limit } \\
\hline & & Low & High & & Low & High & & Low & High & & Low & High \\
\hline $4-10$ & 2,440 & 1,830 & 3,230 & 2,870 & 2,070 & 3,980 & 3,290 & 2,270 & 4,780 & 4,210 & 2,600 & 6,830 \\
\hline $1-2$ & 2,040 & 1,650 & 2,510 & 2,330 & 1,820 & 2,990 & 2,640 & 1,970 & 3,530 & 3,220 & 2,200 & 4,700 \\
\hline $.2-1$ & 320 & 292 & 364 & 340 & 308 & 392 & 359 & 322 & 418 & 397 & 352 & 475 \\
\hline $2-4$ & 5,940 & 5,030 & 7,010 & 6,760 & 5,540 & 8,230 & 7,580 & 6,010 & 9,560 & 9,120 & 7,700 & 11,400 \\
\hline $4-10$ & 15,000 & 12,500 & 18,100 & 17,800 & 14,300 & 22,200 & 20,600 & 16,000 & 26,700 & 27,700 & 19,600 & 39,200 \\
\hline $4-10$ & 15,500 & 11,300 & 21,200 & 19,400 & 13,400 & 27,900 & 23,600 & 15,500 & 35,900 & 34,500 & 20,000 & 59,500 \\
\hline$>10$ & ${ }^{1} 110,000$ & -- & -- & ${ }^{\top} 121,000$ & -- & -- & ז132,000 & --- & -- & ז157,000 & -- & -- \\
\hline $2-4$ & 408,000 & -- & -- & '446,000 & -- & -- & 488,000 & -- & -- & 585,000 & -- & -- \\
\hline $4-10$ & 4,150 & 3,440 & 5,010 & 4,610 & 3,710 & 5,720 & 5,050 & 3,940 & 6,470 & 6,060 & 4,390 & 8,360 \\
\hline $1-2$ & 11,500 & 9,140 & 14,400 & 13,100 & 10,100 & 17,000 & 14,600 & 10,900 & 19,700 & 18,300 & 12,400 & 26,900 \\
\hline $2-4$ & 8,710 & 6,150 & 12,300 & 10,300 & 6,960 & 15,400 & 12,000 & 7,700 & 18,700 & 16,000 & 9,180 & 28,000 \\
\hline $2-4$ & 20,000 & 15,100 & 28,800 & 26,400 & 19,600 & 39,900 & 33,700 & 24,500 & 52,900 & 54,300 & 28,000 & 89,500 \\
\hline $4-10$ & 29,900 & 22,800 & 41,500 & 38,600 & 28,800 & 55,300 & 48,100 & 35,300 & 70,900 & 73,700 & 51,800 & 115,000 \\
\hline $4-10$ & 13,460 & -- & -. & 4,490 & -- & -- & 5,660 & -- & -- & 25,900 & -- & -- \\
\hline $4-10$ & 8,600 & -- & -- & '11,300 & -- & -- & 14,600 & -- & -- & 48,600 & -- & -- \\
\hline $2-4$ & 5,080 & 3,950 & 6,950 & 6,200 & 4,740 & 8,730 & 7,360 & 5,530 & 10,600 & 10,200 & 7,390 & 15,400 \\
\hline $2-4$ & 1968 & -- & -- & '1,680 & -- & -- & 3,160 & -- & -- & 20,900 & -- & -- \\
\hline 4-10 & 11,200 & 7,220 & 19,100 & 14,400 & 9,120 & 25,500 & 17,700 & 11,000 & 32,200 & 25,100 & 15,100 & 48,000 \\
\hline $4-10$ & 6,170 & -- & -- & 8,760 & -- & -- & '12,100 & -- & -- & 27,200 & -- & -- \\
\hline $2-4$ & '10,600 & -- & -- & $' 16,100$ & -- & -- & 24,000 & -- & -- & 168,000 & -- & -- \\
\hline $1-2$ & 23,400 & 17,300 & 34,200 & 32,100 & 23,000 & 49,100 & 42,700 & 29,700 & 68,200 & 76,300 & 49,700 & 134,000 \\
\hline $2-4$ & 41,600 & 26,400 & 72,800 & 52,800 & 32,900 & 95,500 & 63,700 & 38,900 & 118,000 & 86,600 & 51,400 & 168,000 \\
\hline $2-4$ & 61,200 & 47,900 & 83,500 & & 59,800 & 111,000 & 97,800 & 72,900 & 143,000 & 153,000 & 109,000 & 240,000 \\
\hline 4-10 & 37,200 & 31,000 & 46,500 & 46,500 & 37,900 & 59,800 & 57,000 & 45,600 & 75,400 & 86,900 & 66,600 & 122,000 \\
\hline 4-10 & ${ } 16,000$ & 13,400 & 20,200 & ${ }^{420,000}$ & 16,300 & 26,300 & "24,700 & 19,700 & 33,900 & " 39,700 & 29,600 & 59,800 \\
\hline 4-10 & 1,280 & 956 & 1,710 & 1,670 & 1,230 & 2,280 & 2,100 & 1,510 & 2,930 & 3,260 & 2,190 & 4,880 \\
\hline $1-2$ & 27,100 & 23,200 & 31,600 & 30,600 & 25,600 & 36,500 & 34,100 & 27,900 & 41,600 & 42,200 & 32,500 & 54,900 \\
\hline 4-10 & 2,040 & 1,530 & 2,730 & 2,650 & 1,950 & 3,610 & 3,310 & 2,380 & 4,610 & 5,110 & 3,420 & 7,630 \\
\hline$>10$ & "18,200 & 15,000 & 23,300 & ${ }_{23,400}$ & 18,800 & 31,100 & ${ }^{* 29,600}$ & 23,100 & 40,700 & ${ }^{4} 48,700$ & 36,000 & 72,100 \\
\hline $4-10$ & 10,400 & 7,430 & 14,500 & 13,900 & 9,510 & 20,400 & 18,300 & 11,900 & 28,000 & 32,700 & 19,100 & 55,800 \\
\hline$<.2$ & 5,620 & 4,560 & 6,930 & 6,800 & 5,370 & 8,600 & 8,030 & 6,170 & 10,400 & 11,000 & 7,910 & 15,300 \\
\hline 4-10 & $" 102,000$ & 83,400 & 134,000 & "121,000 & 96,600 & 165,000 & "141,000 & 110,000 & 200,000 & "195,000 & 146,000 & 298,000 \\
\hline$>10$ & "129,000 & 107,000 & 165,000 & ${ }^{"} 154,000$ & 125,000 & 201,000 & ${ }^{u} 180,000$ & 144,000 & 241,000 & "246,000 & 189,000 & 348,000 \\
\hline $4-10$ & 29,200 & 24,500 & 34,900 & 33,800 & 27,700 & 41,200 & 38,400 & 30,700 & 48,000 & 49,200 & 36,900 & 65,600 \\
\hline 4-10 & 3,070 & 2,410 & 3,920 & 3,850 & 2,950 & 5,010 & 4,660 & 3,490 & 6,220 & 6,780 & 4,750 & 9,690 \\
\hline $4-10$ & ${ }^{\mathrm{n}} 194,000$ & -- & -- & 220,000 & -- & -- & 250,000 & - & -- & 320,000 & -- & -- \\
\hline $2-4$ & 4,010 & 3,140 & 5,100 & 4,970 & 3,830 & 6,460 & 5,970 & 4,490 & 7,940 & 8,510 & 5,990 & 12,100 \\
\hline$<.2$ & 29,800 & 25,100 & 35,500 & 33,500 & 27,500 & 40,900 & 37,100 & 29,700 & 46,400 & 45,800 & 34,300 & 61,100 \\
\hline $4-10$ & 54,500 & 38,300 & 77,600 & 64,700 & 43,400 & 96,600 & 75,000 & 47,900 & 118,000 & 99,300 & 56,800 & 174,000 \\
\hline$>10$ & "208,000 & -- & -- & 234,000 & -- & - & 260,000 & -- & -- & 324,000 & - & -- \\
\hline $2-4$ & 21,200 & 17,800 & 25,300 & 24,400 & 19,800 & 30,200 & 27,600 & 21,500 & 35,500 & 35,200 & 25,000 & 49,500 \\
\hline $.2-1$ & ${ }^{1} 1,700$ & 1,180 & 2,750 & ${ }^{2}, 520$ & 1,670 & 4,380 & "3,640 & 2,300 & 6,760 & ${ }^{"} 7,920$ & 4,530 & 17,100 \\
\hline $2-4$ & "8,440 & 6,100 & 12,800 & ${ }^{ } 10,400$ & 7,380 & 16,500 & ${ }^{" 12,500}$ & 8,650 & 20,300 & ${ }{ }_{1}^{17,400}$ & 11,600 & 30,100 \\
\hline 4-10 & 8,770 & 5,620 & 13,700 & 12,700 & 7,740 & 20,900 & 17,400 & 10,100 & 30,100 & -- & -- & -- \\
\hline$>10$ & 党306,000 & .- & -- & r351,000 & .- & -- & ז401,000 & ( & - & ${ }^{\mathrm{r}} 532,000$ & -. & -. \\
\hline 4-10 & 18,300 & 13,400 & 25,000 & 22,500 & 15,700 & 32,200 & 26,900 & 17,900 & 40,400 & & -- & \\
\hline
\end{tabular}


Table 5. Summary of peak stages, streamflows, and flood-probability estimates for selected U.S. Geological Survey streamgages during May and June 2008.-Continued

[mi², square mile; ft, foot; fťs, cubic foot per second; AEP, annual exceedance probability; $>$, greater than; <, less than; --, no data; R., River]

\begin{tabular}{|c|c|c|c|c|c|c|c|c|c|c|}
\hline \multirow{3}{*}{$\begin{array}{c}\text { Site } \\
\text { number } \\
\text { (fig. 12) }\end{array}$} & \multirow{3}{*}{$\begin{array}{l}\text { Station } \\
\text { number }\end{array}$} & \multirow{3}{*}{ Station name } & \multirow{3}{*}{$\begin{array}{l}\text { Contributing } \\
\text { drainage } \\
\text { area } \\
\left(\mathrm{mi}^{2}\right)\end{array}$} & \multicolumn{7}{|c|}{ Flood data } \\
\hline & & & & \multicolumn{3}{|c|}{ Previous maximum streamflow } & \multicolumn{4}{|c|}{ Flood of June 2008} \\
\hline & & & & Date & $\begin{array}{c}\text { Stage } \\
\text { (ftt) }\end{array}$ & $\begin{array}{c}\text { Streamflow } \\
\left(\mid t^{2} / s\right)\end{array}$ & $\begin{array}{l}\text { Ranke/ } \\
\text { annual } \\
\text { peaks }\end{array}$ & Date & $\begin{array}{l}\begin{array}{c}\text { Peak } \\
\text { stage } \\
\text { (tt) }\end{array}\end{array}$ & $\begin{array}{c}\text { Peak } \\
\text { streamillow } \\
\left(t^{2} / s\right)\end{array}$ \\
\hline 185 & 06898000 & Thompson River at Davis City, Iowa & 701 & $09 / 1992$ & 24.29 & 57,000 & (p) & 6/7/2008 & 16.46 & 20,900 \\
\hline 186 & 06899500 & Thompson River at Trenton, Mo. & 1,720 & $06 / 1947$ & 25.70 & 95,000 & $\left({ }^{(p)}\right.$ & 6/25/2008 & 31.01 & 50,400 \\
\hline 187 & 06901500 & Locust Creek near Linneus, Mo. & 550 & 06/1947 & 26.93 & 38,000 & $3 / 59$ & 6/25/2008 & 25.83 & 26,900 \\
\hline 188 & 06905500 & Chariton River near Prairie Hill, Mo. & 1,870 & 05/2002 & 23.01 & 37,100 & $\left({ }^{(p)}\right.$ & 6/26/2008 & 22.84 & 36,100 \\
\hline 189 & 06934500 & Missouri River at Hermann, Mo. & 522,500 & 07/1993 & 36.97 & 750,000 & $\left({ }^{(}\right)$ & $6 / 17 / 2008$ & -- & 286,000 \\
\hline 190 & 06935965 & Missouri River at St. Charles, Mo. & 524,000 & 05/2002 & 31.69 & 350,000 & $\left({ }^{(p)}\right.$ & 6/18/2008 & -- & 303,000 \\
\hline 191 & 07010000 & Mississippi River at St. Louis, Mo. & 697,000 & 08/1993 & 49.58 & $1,080,000$ & $25 / 48$ & 6/30/2008 & 38.67 & 1720,000 \\
\hline 192 & 07020500 & Mississippi River at Chester, IIl. & 708,600 & $04 / 1927$ & 34.40 & $1,060,000$ & $21 / 84$ & $7 / 1 / 2008$ & 39.44 & '696,000 \\
\hline 193 & 07022000 & Mississippi River at Thebes, IIl. & 713,200 & 07/1844 & -- & 1,075,000 & $26 / 77$ & 7/3/2008 & 41.10 & 717,000 \\
\hline 194 & 07050700 & James River near Springfield, Mo. & 246 & 07/1909 & 22.00 & 62,000 & $\left({ }^{(p)}\right.$ & $6 / 14 / 2008$ & 18.53 & 28,400 \\
\hline 195 & 07160350 & Skeleton Creek at Enid, Okla. & 70.3 & 11/1998 & 14.70 & ${ }^{18,180}$ & $1 / 13$ & 6/9/2008 & 15.97 & 9,860 \\
\hline 196 & 07176000 & Verdigris River near Claremore, Okla. & 6,534 & $05 / 1943$ & 55.05 & 182,000 & $14 / 74$ & 6/16/2008 & 34.09 & 50,400 \\
\hline 197 & 07176500 & Bird Creek at Avant, Okla. & 364 & 10/1959 & 31.40 & 32,400 & $5 / 64$ & 6/9/2008 & 27.58 & 27,500 \\
\hline
\end{tabular}

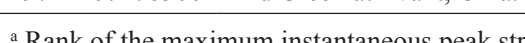

${ }^{2}$ Rank of the maximum instantaneous peak streamflow measured during June 2008 compared to all systematic and historic annual peaks. A rank of 1

Uness otherwie 2008 peak streamflow was higher than all other recorded annual peaks

c Streamflow affected to unknown degree by regulation or diversion.

¿A higher stage exists that corresponds to a streamflow that is less than the peak streamflow

- Streamgage datum changes or stage shifts over period of record. Streamgage vertical datum is referenced to the North American Datum of 1927.

'Datum change at site.

Expected peak streamflows based on Bulletin 17B systematic frequency-curve estimate only

"Estimated.

'Expected peak streamflows are based on regional regression equation estimates only (Eash, 2001).

Expected peak streamflows are based on inclusion of actual, or area-weighted, annual-peak streamflows from an earlier period of record from nearby

discontinued downstream streamgage.

${ }^{k}$ Expected peak streamflows are logarithmic interpolations of weighted estimates between upstream and downstream streamgages.

Streamflow affected by regulation or diversion.

m U.S. Army Corps of Engineers (2009).

"U.S. Army Corps of Engineers (2002).

- Expected peak streamflows are based on weighted estimates from nearby downstream streamgage and regional regression estimates for this streamgage

p The peak streamflow for June 2008 was exceeded by another peak streamflow during 2008.

A higher peak stage of 20.00 occurred in 1929 but corresponded to a lesser peak streamflow.

${ }^{\mathrm{r}}$ U.S. Army Corps of Engineers (2004).

"Estimated AEP uncharacterized because of regulation.

Expected peak streamflows are based on a regional mixed-population analysis (Sando and others, 2008)

"Analysis based on station skew for the current (2008) regulated condition.

\begin{tabular}{|c|c|c|c|c|c|c|c|c|c|c|c|c|}
\hline \multirow{4}{*}{$\begin{array}{l}\text { Estimated } \\
\text { AEP for } \\
\text { observed } \\
\text { peak } \\
\text { streamflow } \\
\text { (percent) }\end{array}$} & \multicolumn{12}{|c|}{ 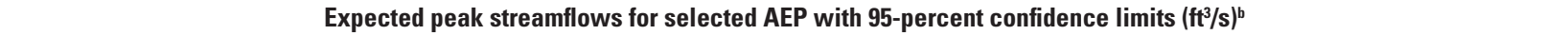 } \\
\hline & \multicolumn{3}{|c|}{$\begin{array}{c}\text { 4-percent AEP } \\
\text { (25-year recurrence) }\end{array}$} & \multicolumn{3}{|c|}{$\begin{array}{c}\text { 2-percent AEP } \\
\text { (50-year recurrence) }\end{array}$} & \multicolumn{3}{|c|}{$\begin{array}{c}\text { 1-percent AEP } \\
\text { (100-year recurrence) }\end{array}$} & \multicolumn{3}{|c|}{$\begin{array}{c}\text { 0.2-percent AEP } \\
\text { (500-year recurrence) }\end{array}$} \\
\hline & \multirow{2}{*}{ Estimate } & \multicolumn{2}{|c|}{ Confidence limit } & \multirow{2}{*}{ Estimate } & \multicolumn{2}{|c|}{ Confidence limit } & \multirow{2}{*}{ Estimate } & \multicolumn{2}{|c|}{ Confidence limit } & \multirow{2}{*}{ Estimate } & \multicolumn{2}{|c|}{ Confidence limit } \\
\hline & & Low & High & & Low & High & & Low & High & & Low & High \\
\hline $4-10$ & 23,900 & 19,800 & 28,700 & 28,300 & 23,000 & 34,700 & 32,800 & 26,100 & 41,100 & 44,000 & 33,100 & 58,700 \\
\hline$>10$ & 63,600 & 53,500 & 75,700 & 72,600 & 58,800 & 89,600 & 81,100 & 63,100 & 104,000 & 99,800 & 70,500 & 141,000 \\
\hline $1-2$ & 23,000 & 19,700 & 27,000 & 26,400 & 21,900 & 31,900 & 29,900 & 23,900 & 37,300 & 37,800 & 27,800 & 51,500 \\
\hline $.2-1$ & & 22,200 & 28,600 & & 24,000 & 32,600 & 30,600 & 25,500 & 36,700 & 36,800 & 28,600 & 47,400 \\
\hline$>10$ & h533,000 & -- & -- & 604,000 & -- & -- & 673,000 & -- & -- & r833,000 & -- & -- \\
\hline$>10$ & ${ }^{n} 536,000$ & -- & -- & 606,000 & -- & -- & '674,000 & -- & -- & 829,000 & -- & -- \\
\hline $4-10$ & 780,000 & -- & -- & 850,000 & -- & -- & r910,000 & -- & -- & $\mathrm{r}_{1}, 120,000$ & -- & -- \\
\hline$>10$ & r85,000 & -- & -- & 893,000 & - & -- & r948,000 & -- & -- & $1,140,000$ & -- & -- \\
\hline $4-10$ & '807,000 & -- & -- & r895,000 & -- & -- & r950,000 & -- & -- & ${ }^{\mathrm{r}}, 142,000$ & -- & -- \\
\hline $4-10$ & 33,200 & 27,600 & 39,900 & 38,200 & 30,700 & 47,500 & 42,900 & 33,300 & 55,300 & 53,400 & 38,300 & 74,500 \\
\hline $4-10$ & 810,000 & 6,920 & 19,400 & 812,100 & 8,060 & 25,700 & 814,400 & 9,230 & 33,200 & 820,400 & 12,200 & 56,300 \\
\hline $4-10$ & 852,100 & 44,800 & 63,700 & 859,600 & 50,400 & 74,600 & 867,300 & 56,100 & 86,100 & 886,000 & 69,500 & 115,000 \\
\hline $4-10$ & 32,100 & 25,600 & 40,300 & 36,300 & 27,600 & 47,800 & 40,800 & 29,500 & 56,500 & 52,300 & 33,400 & 81,900 \\
\hline
\end{tabular}
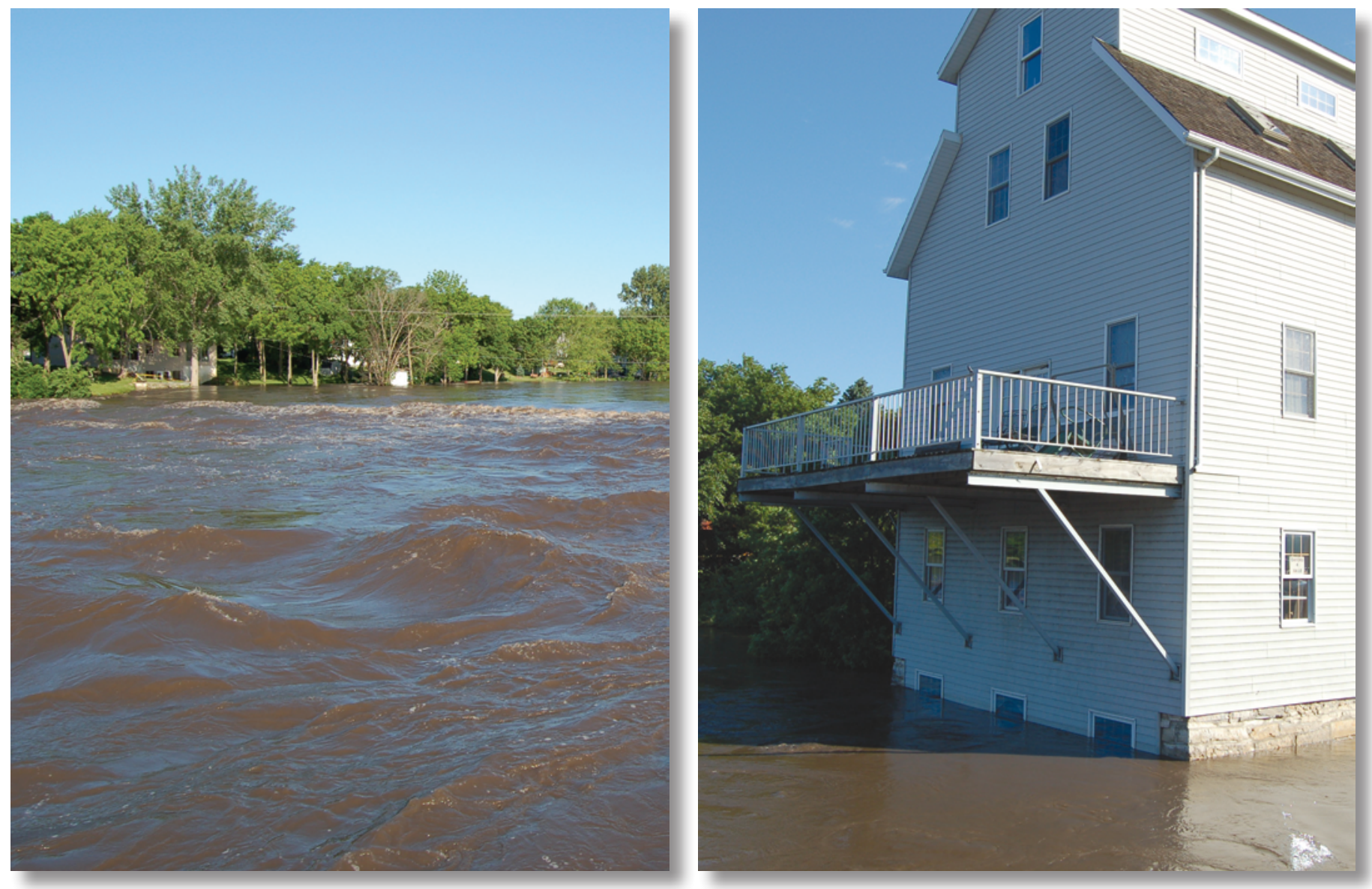

Flooding in Shell Rock, lowa. Photographs by Don Becker, USGS. 
Table 6. Summary of peak stages, streamflows, and flood-probability estimates for selected U.S. Geological Survey streamgages during July 2008

[mi², square mile; ft, foot; fft's, cubic foot per second; AEP, annual exceedance probability; $<$, less than; --, no data]

\begin{tabular}{|c|c|c|c|c|c|c|c|c|c|c|}
\hline \multirow{3}{*}{$\begin{array}{c}\text { Site } \\
\text { number } \\
\text { (fig. 15) }\end{array}$} & \multirow{3}{*}{$\begin{array}{l}\text { Station } \\
\text { number }\end{array}$} & \multirow{3}{*}{ Station name } & \multirow{3}{*}{$\begin{array}{c}\text { Contributing } \\
\text { drainage } \\
\text { area } \\
\left(\mathbf{m i}^{2}\right)\end{array}$} & \multicolumn{7}{|c|}{ Flood data } \\
\hline & & & & \multicolumn{3}{|c|}{ Previous maximum streamflow } & \multicolumn{4}{|c|}{ Flood of July 2008} \\
\hline & & & & Date & $\begin{array}{c}\text { Stage } \\
(\mathrm{ft})\end{array}$ & $\begin{array}{c}\text { Streamflow } \\
\left(\mathrm{ft}^{\prime} / \mathrm{s}\right)\end{array}$ & $\begin{array}{l}\text { Ranke/ } \\
\text { annual } \\
\text { peaks }\end{array}$ & Date & $\begin{array}{l}\text { Peak } \\
\text { stage } \\
(\text { (ft) }\end{array}$ & 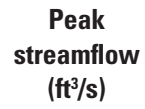 \\
\hline 1 & 05483600 & Middle Raccoon River at Panora, Iowa & 440 & $07 / 1993$ & 20.04 & 22,400 & $3 / 52$ & $7 / 28 / 2008$ & 14.69 & ${ }^{\circ} 14,000$ \\
\hline 2 & 05484000 & South Raccoon River at Redfield, Iowa & 994 & $07 / 1993$ & 26.98 & 44,000 & $2 / 69$ & 7/28/2008 & 24.04 & 37,100 \\
\hline 3 & 05485640 & Fourmile Creek at Des Moines, Iowa & 92.7 & 06/1998 & 15.00 & 5,600 & $\left(^{(d)}\right.$ & $7 / 28 / 2008$ & 15.38 & 6,390 \\
\hline 4 & 05487470 & South River near Ackworth, Iowa & 460 & $06 / 1990$ & 31.25 & 38,100 & $2 / 70$ & 7/29/2008 & 31.57 & 35,700 \\
\hline 5 & 05487825 & Little White Breast Creek Trib. near Chariton, Iowa & .1 & 08/1993 & 18.93 & ${ }^{\mathrm{e} 56}$ & $1 / 19$ & $7 / 28 / 2008$ & 19.72 & 78 \\
\hline 6 & 05487980 & White Breast Creek near Dallas, Iowa & 342 & $07 / 1982$ & 33.45 & 37,300 & 4/46 & $7 / 8 / 2008$ & 28.44 & 16,900 \\
\hline 7 & 05488200 & English Creek near Knoxville, Iowa & 90.1 & $07 / 1982$ & 30.28 & 28,000 & $3 / 24$ & 7/8/2008 & 27.40 & 14,000 \\
\hline 8 & 05489000 & Cedar Creek near Bussey, Iowa & 374 & $07 / 1982$ & 34.61 & 96,000 & $4 / 62$ & $7 / 8 / 2008$ & 28.91 & 30,800 \\
\hline 9 & 05494300 & Fox River at Bloomfield, Iowa & 87.7 & 08/2007 & 25.05 & 13,100 & $2 / 32$ & $7 / 8 / 2008$ & 24.69 & 11,600 \\
\hline 10 & 05502300 & Salt River at Hagers Grove, Mo. & 365 & $05 / 2002$ & 20.91 & 42,000 & 2/35 & $7 / 25 / 2008$ & 20.88 & 29,300 \\
\hline 11 & 05502500 & Salt River near Shelbina, Mo. & 481 & $05 / 2002$ & 28.65 & 24,600 & $1 / 65$ & 7/26/2008 & 28.65 & 28,000 \\
\hline 12 & 05503800 & Crooked Creek near Paris, Mo. & 80.0 & $04 / 1973$ & 15.53 & 12,100 & $4 / 30$ & $7 / 25 / 2008$ & 12.35 & 6,810 \\
\hline 13 & 05504800 & South Fork Salt River above Santa Fe, Mo. & 233 & 09/1993 & 28.66 & 31,800 & $\left({ }^{(d)}\right.$ & 7/26/2008 & 24.72 & 15,500 \\
\hline 14 & 05506100 & Long Branch near Santal Fe, Mo. & 180 & $07 / 1998$ & 22.43 & 16,700 & $1 / 14$ & $7 / 25 / 2008$ & 24.43 & 19,500 \\
\hline 15 & 05506800 & Elk Fork Salt River near Madison, Mo. & 200 & $04 / 1973$ & 33.40 & 42,300 & $3 / 41$ & 7/25/2008 & 30.77 & 24,300 \\
\hline 16 & 05507600 & Lick Creek near Perry, Mo. & 104 & $05 / 1996$ & 22.25 & 11,800 & $2 / 30$ & 7/25/2008 & 26.14 & 15,200 \\
\hline 17 & 05508805 & Spencer Creek at Plum Creek, Frankford, Mo. & 206 & 09/1993 & 18.54 & 20,300 & $1 / 30$ & 7/25/2008 & 19.60 & 20,700 \\
\hline 18 & 06818750 & Platte River near Diagonal, Iowa & 217 & 09/1989 & 23.60 & 8,630 & $1 / 36$ & 7/25/2008 & 25.97 & 13,400 \\
\hline 19 & 06898000 & Thompson River at Davis City, Iowa & 701 & 09/1992 & 24.29 & 57,000 & $5 / 83$ & 7/24/2008 & 16.77 & 21,500 \\
\hline 20 & 06899500 & Thompson River at Trenton, Mo. & 1,720 & 06/1947 & 25.70 & 95,000 & $4 / 84$ & $7 / 25 / 2008$ & 31.96 & 63,400 \\
\hline 21 & 06903700 & South Fork Chariton River near Promise City, Iowa & 168 & 09/1992 & 34.84 & 70,600 & $5 / 42$ & 7/25/2008 & 25.78 & 17,700 \\
\hline 22 & 06904010 & Chariton River near Moulton, Iowa & 740 & 08/2007 & 37.94 & 21,200 & $3 / 29$ & $7 / 9 / 2008$ & 35.81 & ${ }^{\prime} 10,300$ \\
\hline 23 & 06904500 & Chariton River at Novinger, Mo. & 1,370 & 06/1917 & 28.60 & 27,000 & $1 / 86$ & 7/25/2008 & 28.44 & 30,200 \\
\hline 24 & 06905500 & Chariton River near Prairie Hill, Mo. & 1,870 & $05 / 2002$ & 23.01 & 37,100 & $1 / 80$ & 7/27/2008 & 23.27 & ${ }^{c} 38,400$ \\
\hline 25 & 06906150 & Long Banch Creek near Atlanta, Mo. & 23.0 & $05 / 2002$ & 16.44 & 3,360 & $1 / 13$ & $7 / 25 / 2008$ & 16.43 & 4,870 \\
\hline \multicolumn{11}{|c|}{$\begin{array}{l}\text { a Rank of the maximum instantaneous peak streamflow measured during July } 2008 \text { compared to all systematic and historic annual peaks. A rank of } 1 \\
\text { indicates that the July } 2008 \text { peak streamflow was higher than all other recorded annual peaks. }\end{array}$} \\
\hline \\
\hline & & \multicolumn{9}{|c|}{ ‘ Streamflow affected by regulation or diversion. } \\
\hline \multirow{2}{*}{\multicolumn{11}{|c|}{$\begin{array}{l}\text { ' The peak streamflow for July } 2008 \text { was exceeded by another peak streamflow during } 2008 . \\
{ }^{\circ} \text { Estimated. }\end{array}$}} \\
\hline \multicolumn{2}{|c|}{ ‘ Estimated. } & & & & & & & & & \\
\hline \multicolumn{11}{|c|}{${ }^{\mathrm{f} E x p e c t e d ~ p e a k ~ s t r e a m f l o w s ~ b a s e d ~ o n ~ B u l l e t i n ~ 17 B ~ s y s t e m a t i c ~ f r e q u e n c y-c u r v e ~ e s t i m a t e ~ o n l y . ~}$} \\
\hline 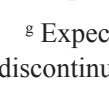 & 20 & 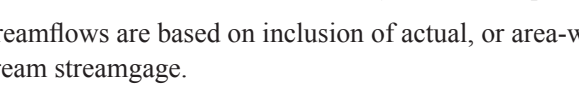 & 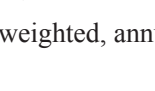 & & & & & & & \\
\hline
\end{tabular}

\begin{tabular}{|c|c|c|c|c|c|c|c|c|c|c|c|c|}
\hline \multirow{4}{*}{$\begin{array}{l}\text { Estimated } \\
\text { AEP for } \\
\text { observed } \\
\text { peak } \\
\text { streamflow } \\
\text { (percent) }\end{array}$} & \multicolumn{12}{|c|}{ Expected peak streamfllows for selected AEP with 95-percent confidence limits $\left(\mathrm{t}^{2} / \mathrm{s}^{b}\right.$} \\
\hline & \multicolumn{3}{|c|}{$\begin{array}{l}\text { 4-percent AEP } \\
\text { (25-year recurrence) }\end{array}$} & \multicolumn{3}{|c|}{$\begin{array}{l}\text { 2-percent AEP } \\
\text { (50-year recurrence) }\end{array}$} & \multicolumn{3}{|c|}{$\begin{array}{c}\text { 1-percent AEP } \\
\text { (100-year recurrence) }\end{array}$} & \multicolumn{3}{|c|}{$\begin{array}{c}\text { 0.2-percent AEP } \\
\text { (500-year recurrence) } \\
\end{array}$} \\
\hline & \multirow{2}{*}{ Estimate } & \multicolumn{2}{|c|}{ Confidence limit } & \multirow{2}{*}{ Estimate } & \multicolumn{2}{|c|}{ Confidence limit } & \multirow{2}{*}{ Estimate } & \multicolumn{2}{|c|}{ Confidence limit } & \multirow{2}{*}{ Estimate } & \multicolumn{2}{|c|}{ Confidence limit } \\
\hline & & Low & High & & Low & High & & Low & High & & Low & High \\
\hline $2-4$ & 14,000 & 11,900 & 16,400 & 16,700 & 13,900 & 20,000 & 19,500 & 15,800 & 23,900 & 26,400 & 20,100 & 34,600 \\
\hline $.2-1$ & 27,400 & 22,900 & 32,800 & 31,600 & 25,900 & 38,600 & 35,800 & 28,600 & 44,800 & 45,900 & 34,400 & 61,100 \\
\hline $2-4$ & 6,140 & 4,880 & 7,730 & 7,330 & 5,690 & 9,440 & 8,580 & 6,500 & 11,300 & 11,800 & 8,310 & 16,600 \\
\hline $2-4$ & 31,000 & 25,500 & 37,500 & 36,200 & 29,100 & 44,900 & 41,400 & 32,400 & 52,700 & 53,500 & 39,200 & 73,000 \\
\hline $2-4$ & ${ }^{5} 74$ & 53 & 126 & 90 & 62 & 164 & ${ }^{\mathrm{f}} 108$ & 72 & 206 & ${ }^{\mathrm{f}} 152$ & 96 & 329 \\
\hline $4-10$ & 819,100 & 15,700 & 23,200 & 822,700 & 18,400 & 28,100 & 826,500 & 21,000 & 33,400 & 836,300 & 27,200 & 48,400 \\
\hline $1-2$ & 9,510 & 7,270 & 12,400 & 11,600 & 8,720 & 15,500 & 14,100 & 10,300 & 19,300 & 20,900 & 14,200 & 30,800 \\
\hline $2-4$ & 28,000 & 23,400 & 33,400 & 33,400 & 27,400 & 40,800 & 39,000 & 31,200 & 48,800 & 53,500 & 40,200 & 71,100 \\
\hline $2-4$ & 11,500 & 9,080 & 14,500 & 14,000 & 10,900 & 17,900 & 16,500 & 12,700 & 21,500 & 23,400 & 16,900 & 32,200 \\
\hline $2-4$ & 27,600 & 22,100 & 34,500 & 32,000 & 24,600 & 41,600 & 36,200 & 26,700 & 49,200 & 46,000 & 30,500 & 69,400 \\
\hline $.2-1$ & 19,300 & 16,200 & 23,000 & 22,600 & 18,300 & 27,900 & 26,000 & 20,300 & 33,300 & 34,100 & 24,400 & 47,800 \\
\hline$>10$ & 8,900 & 6,780 & 11,700 & 10,300 & 7,540 & 14,200 & 11,800 & 8,200 & 16,900 & 15,200 & 9,520 & 24,200 \\
\hline $4-10$ & 20,000 & 13,700 & 29,100 & 23,600 & 15,400 & 36,100 & 27,300 & 17,000 & 43,900 & 36,200 & 20,100 & 65,100 \\
\hline $1-2$ & 16,200 & 11,400 & 23,000 & 18,600 & 12,500 & 27,800 & 21,200 & 13,600 & 33,000 & 27,400 & 15,800 & 47,600 \\
\hline $2-4$ & 21,700 & 16,000 & 29,600 & 25,700 & 18,000 & 36,700 & 29,700 & 19,800 & 44,600 & 39,400 & 23,400 & 66,100 \\
\hline $2-4$ & 14,500 & 11,400 & 18,400 & 16,600 & 12,600 & 22,000 & 18,800 & 13,600 & 25,800 & 23,900 & 15,700 & 36,400 \\
\hline $2-4$ & 19,400 & 16,100 & 23,300 & 21,200 & 17,100 & 26,400 & 23,000 & 17,900 & 29,600 & 27,100 & 19,400 & 37,800 \\
\hline $1-2$ & 10,800 & 9,060 & 12,900 & 12,500 & 10,300 & 15,300 & 14,300 & 11,500 & 17,800 & 18,200 & 13,800 & 24,100 \\
\hline 4-10 & 23,900 & 19,800 & 28,700 & 28,300 & 23,000 & 34,700 & 32,800 & 26,100 & 41,100 & 44,000 & 33,100 & 58,700 \\
\hline $4-10$ & 63,600 & 53,500 & 75,700 & 72,600 & 58,800 & 89,600 & 81,100 & 63,100 & 104,000 & 99,800 & 70,500 & 141,000 \\
\hline $4-10$ & 17,900 & 14,900 & 21,500 & 21,000 & 17,100 & 25,700 & 24,400 & 19,400 & 30,500 & 33,600 & 25,300 & 44,600 \\
\hline$<2$ & " 8,130 & -- & -- & ${ }^{8} 8,660$ & -- & -- & -- & - & -- & - & - & -- \\
\hline $1-2$ & 25,900 & 21,600 & 31,200 & 30,100 & 24,100 & 37,700 & 34,400 & 26,300 & 44,900 & 44,300 & 30,700 & 64,000 \\
\hline$<.2$ & 25,200 & 22,200 & 28,600 & 28,000 & 24,000 & 32,600 & 30,600 & 25,500 & 36,700 & 36,800 & 28,600 & 47,400 \\
\hline $2-4$ & 4,230 & 2,640 & 6,780 & 5,100 & 3,040 & 8,560 & 6,020 & 3,430 & 10,600 & 8,240 & 4,230 & 16,000 \\
\hline
\end{tabular}

Flooding in Spencer, Indiana. Photograph by Paul Baker, USGS.

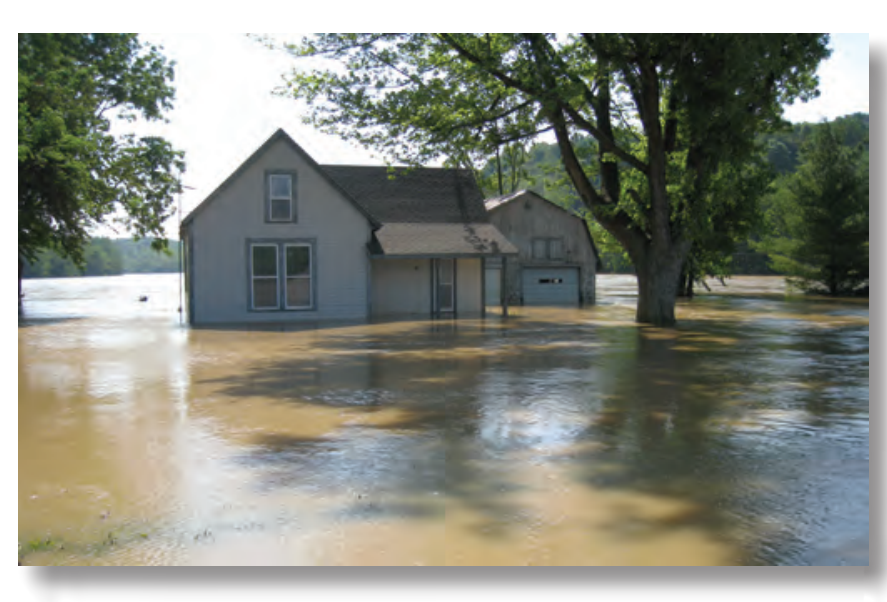

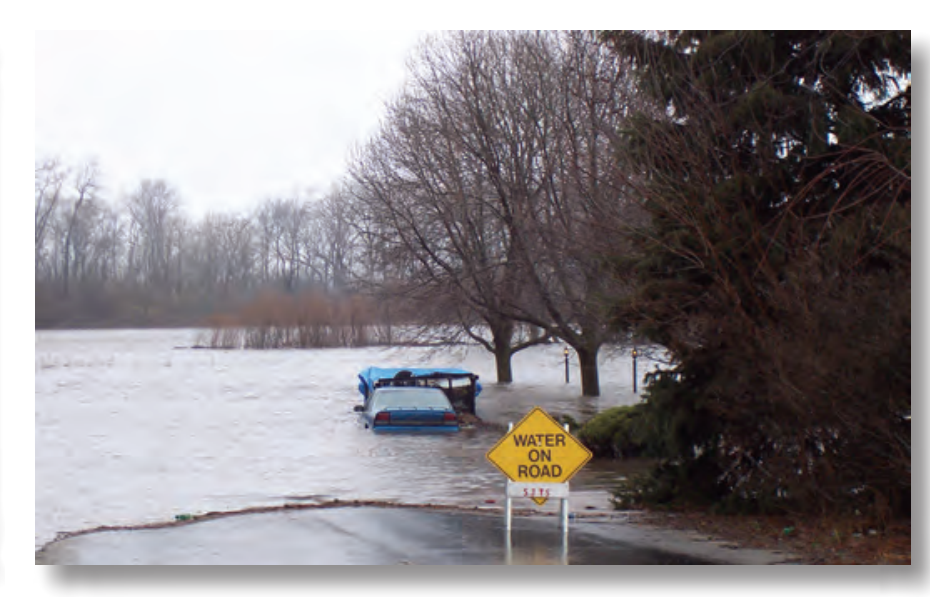

Flooding in St. Joseph, Illinois. Photograph by Robert Holmes, USGS. 
Table 7. Summary of peak stages, streamflows, and flood-probability estimates for selected U.S. Geological Survey streamgages during September 2008 .

[mi2, square mile; ft, foot; fi³/s, cubic foot per second; AEP, annual exceedance probability; <, less than; --, no data; Br, Branch; >, greater than]

Flood data

\begin{tabular}{|c|c|c|c|c|c|c|c|c|c|c|}
\hline \multirow{3}{*}{$\begin{array}{c}\text { Site } \\
\text { number } \\
\text { (fig. 16) }\end{array}$} & \multirow{3}{*}{$\begin{array}{l}\text { Station } \\
\text { number }\end{array}$} & \multirow{3}{*}{ Station name } & \multirow{3}{*}{$\begin{array}{c}\text { Contributing } \\
\text { drainage } \\
\text { area } \\
\left(\mathrm{mi}^{2}\right)\end{array}$} & \\
\hline & & & & \multicolumn{3}{|c|}{ Previous maximum streamflow } & \multicolumn{4}{|c|}{ Flood of September 2008} \\
\hline & & & & Date & $\begin{array}{c}\text { Stage } \\
\text { (tit) }\end{array}$ & $\begin{array}{c}\text { Streamfllow } \\
\left(\left|\mathrm{t}^{2} / \mathbf{s}\right|\right.\end{array}$ & $\begin{array}{l}\text { Rank }{ }^{2 /} \\
\text { annual } \\
\text { peaks }\end{array}$ & Date & $\begin{array}{c}\text { Peak } \\
\text { stage } \\
\text { (ft) }\end{array}$ & 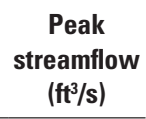 \\
\hline 1 & 04093000 & Deep River at Lake George Outlet, Hobart, Ind. & 124 & $11 / 1990$ & 17.58 & 4,230 & $1 / 62$ & 9/15/2008 & 22.18 & 5,280 \\
\hline 2 & 04094000 & Little Calumet River at Porter, Ind. & 66.2 & 11/1990 & 10.93 & 3,880 & $1 / 64$ & 9/15/2008 & 12.04 & 5,320 \\
\hline 3 & 04095300 & Trail Creek at Michigan City, Ind. & 54.1 & 06/1993 & 12.97 & 4,240 & 3/26 & 9/14/2008 & 13.07 & 3,310 \\
\hline 4 & 04096015 & Galien River near Sawyer, Mich. & 80.7 & $05 / 1996$ & 14.13 & 3,440 & $2 / 13$ & 9/15/2008 & 13.26 & 2,510 \\
\hline 5 & 04096405 & St. Joseph River at Burlington, Mich. & 206 & 06/1989 & 5.82 & 1,390 & $4 / 47$ & 9/16/2008 & 6.83 & 1,130 \\
\hline 6 & 04097500 & St. Joseph River at Three Rivers, Mich. & 1,350 & 04/1950 & 10.60 & 8,260 & (d) & 9/17/2008 & 9.29 & 6,120 \\
\hline 7 & 04099000 & St. Joseph River at Mottville, Mich. & 1,866 & 06/1989 & 10.41 & ${ }^{\prime} 11,400$ & (d) & 9/17/2008 & 8.25 & e7,550 \\
\hline 8 & 04101370 & Juday Creek near South Bend, Ind. & 38.0 & 06/1993 & 3.39 & 226 & $1 / 16$ & 9/15/2008 & 3.65 & 249 \\
\hline 9 & 04101800 & Dowagiac River at Sumnerville, Mich. & 255 & $02 / 1985$ & 9.26 & 1,590 & $1 / 49$ & 9/15/2008 & 11.60 & 2,300 \\
\hline 10 & 04102500 & Paw Paw River at Riverside, Mich. & 390 & 10/1986 & 10.90 & 3,580 & $1 / 57$ & 9/17/2008 & 11.24 & 3,870 \\
\hline 11 & 04102700 & South Branch Black River near Bangor, Mich. & 83.6 & 02/1997 & 14.90 & 2,390 & 2/43 & 9/15/2008 & 13.78 & 1,950 \\
\hline 12 & 04103010 & Kalamazoo River near Marengo, Mich. & 267 & 06/1989 & 10.18 & 1,160 & $2 / 22$ & 9/14/2008 & 10.05 & 1,120 \\
\hline 13 & 04103500 & Kalamazoo River at Marshall, Mich. & 449 & 03/1950 & 8.20 & 2,130 & $2 / 42$ & 9/15/2008 & 7.89 & 2,030 \\
\hline 14 & 04105000 & Battle Creek at Battle Creek, Mich. & 241 & 04/1947 & 4.48 & 3,640 & 9/77 & 9/17/2008 & 3.46 & 2,410 \\
\hline 15 & 04105500 & Kalamazoo River near Battle Creek, Mich. & 824 & 04/1947 & -- & 7,290 & $3 / 72$ & 9/17/2008 & 7.78 & 5,240 \\
\hline 16 & 04105700 & Augusta Creek near Augusta, Mich. & 38.9 & 06/1978 & 3.41 & 560 & $2 / 44$ & 9/14/2008 & 3.48 & 312 \\
\hline 17 & 04106000 & Kalamazoo River at Comstock, Mich. & 1,010 & 04/1947 & 7.94 & 6,910 & 4/72 & 9/18/2008 & 10.43 & 5,670 \\
\hline 18 & 04106300 & Portage Creek near Kalamazoo, Mich. & 22.4 & 05/1989 & 3.09 & 407 & $2 / 44$ & 9/14/2008 & 3.43 & 398 \\
\hline 19 & 04106320 & West Fork Portage Creek near Oshtemo, Mich. & 13.0 & 12/1992 & 2.47 & 36 & $3 / 37$ & 9/15/2008 & 2.17 & 26 \\
\hline 20 & 04106400 & West Fork Portage Creek at Kalamazoo, Mich. & 18.7 & 12/1992 & 3.23 & 41 & $1 / 49$ & 9/15/2008 & 3.69 & 69 \\
\hline 21 & 04108600 & Rabbit River near Hopkins, Mich. & 71.4 & 06/1997 & 11.11 & 3,740 & (') & 9/14/2008 & 8.90 & 1,360 \\
\hline 22 & 04111000 & Grand River near Eaton Rapids, Mich. & 661 & $04 / 1950$ & 8.15 & 3,860 & $2 / 47$ & 9/16/2008 & 8.17 & 3,590 \\
\hline 23 & 04112700 & Sycamore Creek at Harper Rd near Mason, Mich. & 39.5 & $04 / 1975$ & 12.53 & 1,080 & $3 / 34$ & 9/15/2008 & 12.08 & 879 \\
\hline 24 & 05448000 & Mill Creek at Milan, IIl. & 62.4 & 04/1973 & 11.65 & 9,300 & $3 / 67$ & 9/13/2008 & $\$ 11.37$ & 8,790 \\
\hline 25 & 05466500 & Edwards River near New Boston, III. & 445 & $04 / 1973$ & 23.33 & 18,000 & $2 / 74$ & 9/14/2008 & 24.13 & 10,300 \\
\hline 26 & 05469350 & Haight Creek at Kingston, Iowa & 2.7 & 06/2007 & 18.16 & 2,450 & $2 / 19$ & 9/13/2008 & ${ }^{\prime} 16.02$ & ${ }^{\mathrm{f}}, 740$ \\
\hline 27 & 05473400 & Cedar Creek near Oakland Mills, Iowa & 530 & 08/2007 & 21.28 & 13,100 & $1 / 31$ & 9/14/2008 & 21.96 & 14,100 \\
\hline 28 & 05473450 & Big Creek north of Mount Pleasant, Iowa & 58.0 & 04/1973 & -- & 9,580 & $2 / 12$ & 9/13/2008 & 16.90 & 4,520 \\
\hline 29 & 05495000 & Fox River at Waylund, Mo. & 400 & 04/1973 & 21.71 & 26,400 & 4/87 & 9/15/2008 & 20.61 & 18,600 \\
\hline 30 & 05502500 & Salt River near Shelbina, Mo. & 481 & 05/2002 & 28.65 & 24,600 & (d) & 9/16/2008 & 24.29 & 17,800 \\
\hline 31 & 05504800 & South Fork Salt River above Santa Fe, Mo. & 233 & 09/1993 & 28.66 & 31,800 & $2 / 21$ & 9/15/2008 & 26.60 & 22,100 \\
\hline 32 & 05512500 & Bay Creek at Pittsfield, III. & 39.4 & 09/1926 & 18.40 & 35,000 & $3 / 70$ & 9/14/2008 & 14.75 & 12,900 \\
\hline 33 & 05515500 & Kankakee River at Davis, Ind. & 537 & 01/2005 & 13.05 & 1,930 & (d) & 9/15/2008 & 13.74 & 1,900 \\
\hline 34 & 05518000 & Kankakee River at Shelby, Ind. & 1,779 & $03 / 1982$ & 12.98 & 7,650 & $5 / 86$ & 9/19/2008 & :12.86 & 6,230 \\
\hline 35 & 05520500 & Kankakee River at Momence, Ill. & 2,294 & 03/1979 & 10.51 & ${ }_{1}^{16,000}$ & 2/94 & 9/15/2008 & 6.98 & 11,800 \\
\hline 36 & 05527500 & Kankakee River near Wilmington, IIl. & 5,150 & 07/1957 & 11.40 & 75,900 & (') & 9/15/2008 & 8.68 & 48,800 \\
\hline 37 & 05530990 & Salt Creek at Rolling Meadows, IIll. & 30.5 & 08/1987 & 14.03 & 1,650 & $1 / 35$ & 9/13/2008 & 12.99 & $\mathrm{~m}_{2,510}$ \\
\hline 38 & 05531300 & Salt Creek at Elmhurst, IIl. & 91.5 & 08/1972 & 7.27 & 2,230 & $2 / 45$ & 9/14/2008 & 13.27 & i,940 \\
\hline 39 & 05531500 & Salt Creek at Western Springs, Ill. & 115 & 08/1987 & 10.54 & 3,540 & 2/63 & 9/14/2008 & 9.92 & 2,890 \\
\hline 40 & 05532000 & Addison Creek at Bellwood, IIl. & 17.9 & 08/1987 & 12.84 & 1,120 & $4 / 58$ & & 10.33 & 808 \\
\hline
\end{tabular}

\begin{tabular}{|c|c|c|c|c|c|c|c|c|c|c|c|c|}
\hline \multirow{4}{*}{$\begin{array}{c}\text { Estimated } \\
\text { AEP for } \\
\text { observed } \\
\text { peak } \\
\text { streamflow } \\
\text { (percent) }\end{array}$} & \multicolumn{12}{|c|}{ Expected peak streamflows for selected AEP with 95-percent confidence limits $\left(\mathrm{ft}^{3} / \mathrm{s}^{b}\right.$} \\
\hline & \multicolumn{3}{|c|}{$\begin{array}{l}\text { 4-percent AEP } \\
\text { (25-year recurrence) }\end{array}$} & \multicolumn{3}{|c|}{$\begin{array}{c}\text { 2-percent AEP } \\
\text { (50-year recurrence) }\end{array}$} & \multicolumn{3}{|c|}{$\begin{array}{c}\text { 1-percent AEP } \\
\text { (100-year recurrence) }\end{array}$} & \multicolumn{3}{|c|}{$\begin{array}{c}\text { 0.2-percent AEP } \\
\text { (500-year recurrence) }\end{array}$} \\
\hline & \multirow[b]{2}{*}{ Estimate } & \multicolumn{2}{|c|}{ Confidence limit } & \multirow[b]{2}{*}{ Estimate } & \multicolumn{2}{|c|}{ Confidence limit } & \multirow[b]{2}{*}{ Estimate } & \multicolumn{2}{|c|}{ Confidence limit } & \multirow[b]{2}{*}{ Estimate } & \multicolumn{2}{|c|}{ Confidence limit } \\
\hline & & Low & High & & Low & High & & Low & High & & Low & High \\
\hline $1-2$ & 4,440 & 3,530 & 6,380 & 5,220 & 4,040 & 7,910 & 6,070 & 4,570 & 9,670 & 8,320 & 5,900 & 14,800 \\
\hline $2-4$ & 4,490 & 3,230 & 7,530 & 5,660 & 3,920 & 10,300 & 7,010 & 4,680 & 13,700 & 11,000 & 6,750 & 25,200 \\
\hline $2-4$ & 3,190 & 2,190 & 4,640 & 3,770 & 2,480 & 5,730 & 4,350 & 2,750 & 6,890 & 5,820 & 3,390 & 9,990 \\
\hline 4-10 & 2,880 & 2,210 & 4,580 & $c^{c}, 370$ & 2,510 & 5,770 & ‘3,910 & 2,820 & 7,160 & ${ }^{\circ}, 330$ & 3,600 & 11,300 \\
\hline $4-10$ & ${ }^{\circ} 1,250$ & 1,100 & 1,500 & ${ }{ }^{1}, 400$ & 1,210 & 1,710 & ${ }^{\circ} 1,550$ & 1,320 & 1,920 & ${ }^{\mathrm{c}} 1,890$ & 1,570 & 2,430 \\
\hline 4-10 & ${ }^{\circ} 6,360$ & 5,720 & 7,310 & ‘6,970 & 6,200 & 8,140 & ${ }^{7} 7,560$ & 6,660 & 8,950 & 8,900 & 7,680 & 10,900 \\
\hline 4-10 & 8,780 & 8,080 & 9,730 & c9,800 & 8,930 & 11,000 & ${ }^{`} 10,800$ & 9,780 & 12,300 & ${ }^{`} 13,400$ & 11,800 & 15,700 \\
\hline $2-4$ & ${ }^{\circ} 238$ & 173 & 410 & ${ }^{\prime} 282$ & 199 & 521 & ${ }^{9} 329$ & 225 & 649 & ${ }^{\circ} 450$ & 288 & 1,020 \\
\hline$<1$ & 1,590 & 1,360 & 1,850 & 1,770 & 1,470 & 2,130 & 1,950 & 1,570 & 2,430 & - & - & -- \\
\hline $1-2$ & 2,980 & 2,430 & 3,650 & 3,450 & 2,700 & 4,400 & 3,950 & 2,960 & 5,250 & - & - & - \\
\hline $2-4$ & 1,860 & 1,460 & 2,360 & 2,150 & 1,620 & 2,860 & 2,470 & 1,780 & 3,440 & -- & -- & -- \\
\hline $2-4$ & ${ }^{\circ} 1,080$ & 950 & 1,320 & ‘ 1,180 & 1,020 & 1,470 & ${ }^{\circ} 1,280$ & 1,090 & 1,630 & ${ }{ }^{1}, 500$ & 1,250 & 2,010 \\
\hline $2-4$ & 1,910 & 1,590 & 2,290 & 2,150 & 1,740 & 2,660 & 2,410 & 1,880 & 3,080 & -- & -- & -- \\
\hline 4-10 & 2,800 & 2,340 & 3,350 & 3,210 & 2,580 & 3,980 & 3,620 & 2,810 & 4,670 & -- & -- & -- \\
\hline 4-10 & 5,340 & 4,510 & 6,320 & 6,110 & 4,990 & 7,490 & 6,930 & 5,460 & 8,790 & - & -- & - \\
\hline $1-2$ & 263 & 206 & 336 & 303 & 226 & 406 & 344 & 244 & 485 & -- & -- & -- \\
\hline $2-4$ & ${ }^{\complement 5,640}$ & 5,080 & 6,420 & ${ }^{6}, 300$ & 5,620 & 7,280 & ${ }^{\circ} 6,960$ & 6,140 & 8,150 & ${ }^{8}, 510$ & 7,360 & 10,300 \\
\hline$<1$ & 288 & 234 & 355 & 323 & 252 & 415 & 360 & 269 & 481 & -- & - & -- \\
\hline 4-10 & ${ }^{2} 29$ & 25 & 35 & 33 & 28 & 41 & 38 & 32 & 48 & ${ }^{\circ} 49$ & 40 & 67 \\
\hline $.2-1$ & ${ }^{\circ} 47$ & 42 & 55 & ${ }_{53}$ & 46 & 63 & ‘59 & 51 & 72 & ${ }^{`} 75$ & 63 & 95 \\
\hline 4-10 & 1,550 & 1,140 & 2,100 & 1,830 & 1,270 & 2,620 & 2,120 & 1,400 & 3,200 & -- & - & -- \\
\hline 4-10 & c3,970 & 3,520 & 4,640 & ${ }^{\circ}, 360$ & 3,830 & 5,190 & 4,750 & 4,130 & 5,730 & ${ }^{` 5,610}$ & 4,780 & 6,980 \\
\hline $2-4$ & ${ }^{\circ} 877$ & 731 & 1,130 & ${ }^{{ }^{1}, 040}$ & 845 & 1,390 & ${ }^{{ }^{1}, 210}$ & 966 & 1,680 & ${ }^{\circ} 1,680$ & 1,280 & 2,520 \\
\hline 4-10 & 9,090 & 7,110 & 11,600 & 10,800 & 8,110 & 14,300 & 12,500 & 8,980 & 17,300 & 16,500 & 10,700 & 25,400 \\
\hline $2-4$ & 10,200 & 8,490 & 12,200 & 11,800 & 9,500 & 14,600 & 13,400 & 10,400 & 17,100 & 17,200 & 12,300 & 24,000 \\
\hline 4-10 & 2,270 & 1,710 & 3,000 & 2,860 & 2,110 & 3,860 & 3,500 & 2,530 & 4,860 & 5,280 & 3,540 & 7,860 \\
\hline $2-4$ & 13,600 & 11,400 & 16,200 & 15,700 & 12,900 & 19,000 & 17,800 & 14,300 & 22,100 & 22,700 & 17,300 & 29,900 \\
\hline 4-10 & 5,300 & 3,990 & 7,050 & 6,490 & 4,810 & 8,770 & 7,710 & 5,590 & 10,600 & 10,800 & 7,330 & 16,000 \\
\hline 4-10 & 18,900 & 15,600 & 22,900 & 22,300 & 17,700 & 28,000 & 25,900 & 19,800 & 33,800 & 34,600 & 24,100 & 49,600 \\
\hline 4-10 & 19,300 & 16,200 & 23,000 & 22,600 & 18,300 & 27,900 & 26,000 & 20,300 & 33,300 & 34,100 & 24,400 & 47,800 \\
\hline $2-4$ & 20,000 & 13,700 & 29,100 & 23,600 & 15,400 & 36,100 & 27,300 & 17,000 & 43,900 & 36,200 & 20,100 & 65,100 \\
\hline 4-10 & 14,300 & 11,200 & 18,200 & 17,000 & 12,800 & 22,600 & 19,600 & 14,100 & 27,300 & 25,500 & 16,500 & 39,400 \\
\hline $2-4$ & 1,830 & 1,710 & 1,960 & 1,940 & 1,790 & 2,100 & 2,050 & 1,860 & 2,250 & 2,300 & 2,010 & 2,620 \\
\hline 4-10 & 6,370 & 5,940 & 6,830 & 6,730 & 6,180 & 7,320 & 7,060 & 6,390 & 7,810 & 7,760 & 6,740 & 8,930 \\
\hline $2-4$ & 11,700 & 10,600 & 12,900 & 12,600 & 11,300 & 14,200 & 13,500 & 11,800 & 15,500 & 15,300 & 12,600 & 18,400 \\
\hline 4-10 & 54,700 & 47,300 & 63,300 & 61,300 & 51,600 & 72,900 & 67,500 & 55,200 & 82,600 & 80,800 & 61,300 & 106,000 \\
\hline$<.2$ & 1,520 & 1,320 & 1,860 & 1,690 & 1,440 & 2,110 & 1,850 & 1,560 & 2,360 & 2,220 & 1,820 & 2,950 \\
\hline j.- & -- & -- & -- & - & - & - & - & - & - & - & - & - \\
\hline j.- & -- & -- & -- & -- & -- & -- & -- & -- & -- & -- & -- & -- \\
\hline $4-10$ & ‘858 & 767 & 988 & c944 & 837 & 1,100 & ${ }^{\mathrm{c}} 1,030$ & 902 & 1,220 & ${ }^{\circ} 1,210$ & 1,050 & 1,470 \\
\hline
\end{tabular}


Table 7. Summary of peak stages, streamflows, and flood-probability estimates for selected U.S. Geological Survey streamgages during September 2008.-Continued

[mi², square mile; ft, foot; ff/s, cubic foot per second; AEP, annual exceedance probability; <, less than; --, no data; Br., Branch; >, greater than]

Flood data

\begin{tabular}{|c|c|c|c|c|c|c|c|c|c|c|}
\hline \multirow{3}{*}{$\begin{array}{c}\text { Site } \\
\text { number } \\
\text { (fig. 16) }\end{array}$} & \multirow{3}{*}{$\begin{array}{l}\text { Station } \\
\text { number }\end{array}$} & \multirow{3}{*}{ Station name } & \multirow{3}{*}{$\begin{array}{c}\text { Contributing } \\
\text { drainage } \\
\text { area } \\
\text { (mi') }\end{array}$} & \\
\hline & & & & Previou & maximu & n streamflow & & od of $\mathrm{S}$ & ptember 2 & \\
\hline & & & & Date & $\begin{array}{c}\text { Stage } \\
\text { (tt) }\end{array}$ & $\begin{array}{c}\text { Streamfllow } \\
\left(\mid t^{\prime} / s\right)\end{array}$ & $\begin{array}{l}\text { Ranka/ } \\
\text { annual } \\
\text { peaks }\end{array}$ & Date & $\begin{array}{c}\text { Peak } \\
\text { stage } \\
\text { (ft) }\end{array}$ & $\begin{array}{l}\text { Peak } \\
\text { streamflow } \\
\left(t t^{3} / \mathrm{s}\right)\end{array}$ \\
\hline
\end{tabular}

$41 \quad 05532500$ Des Plaines River at Riverside, III. $\quad \begin{array}{lllllllll} & 630 & 08 / 1987 & 9.90 & 9,770 & 2 / 95 & 9 / 14 / 2008 & 9.87 & 9,560\end{array}$

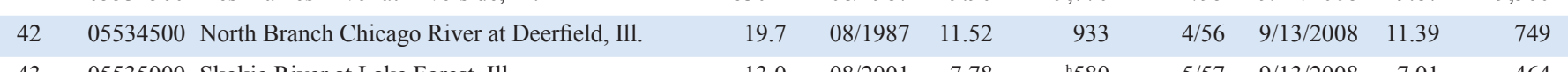

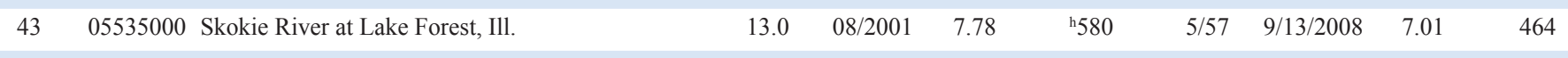

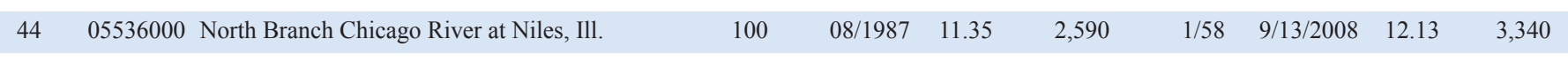

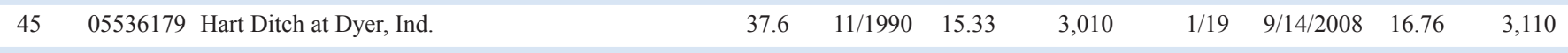

$46 \quad 05536190$ Hart Ditch at Munster, Ind. $\quad \begin{array}{lllllllll}70.7 & 09 / 2006 & - & 3,260 & 1 / 66 & 9 / 14 / 2008 & 9.94 & \text { h.3,840 }\end{array}$

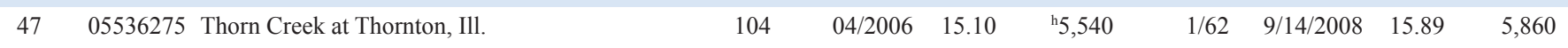

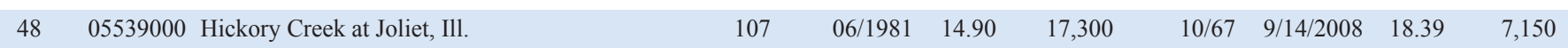

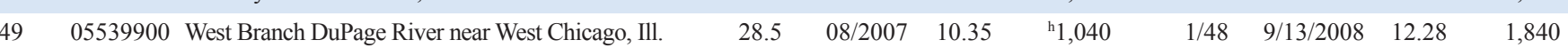

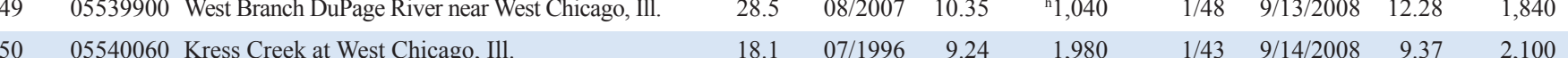

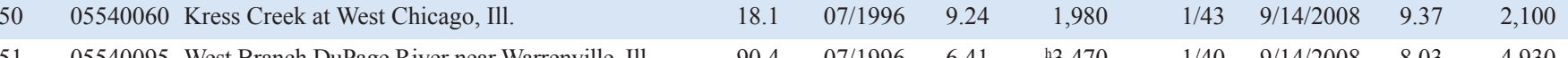

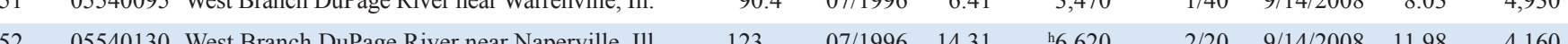

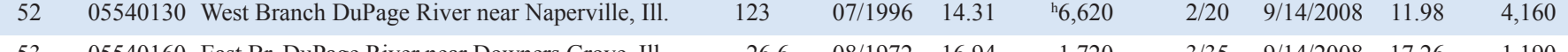

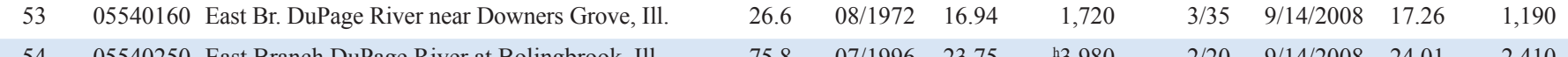

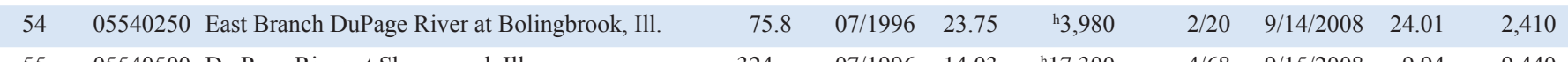

$\begin{array}{lllllllllll}55 & 05540500 & \text { Du Page River at Shorewood, IIl. } & 324 & 07 / 1996 & 14.03 & { }^{{ }_{1}} 7,300 & 4 / 68 & 9 / 15 / 2008 & 9.94 & 9,440\end{array}$

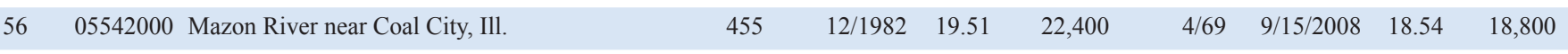

$\begin{array}{lllllllllll}57 & 05550300 & \text { Tyler Creek at Elgin, Ill. } & 38.9 & 08 / 2002 & 8.26 & { }^{1} 1,650 & 3 / 28 & 9 / 13 / 2008 & 8.53 & 1,250\end{array}$

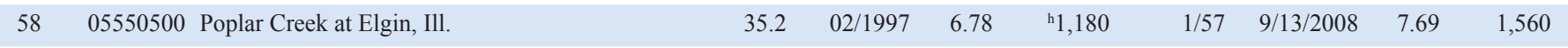

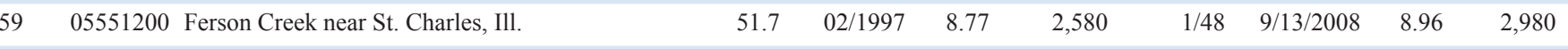

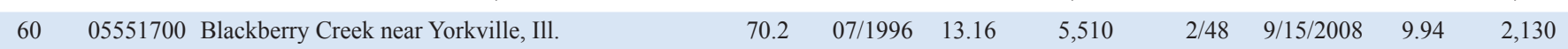

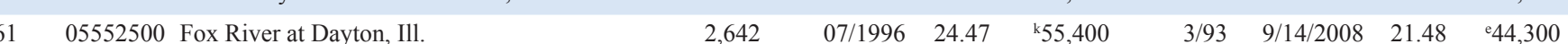

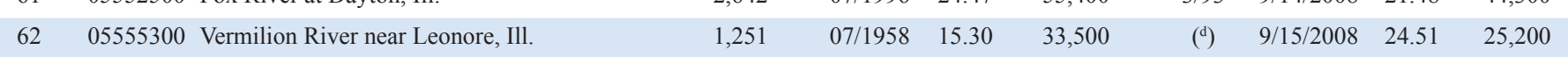

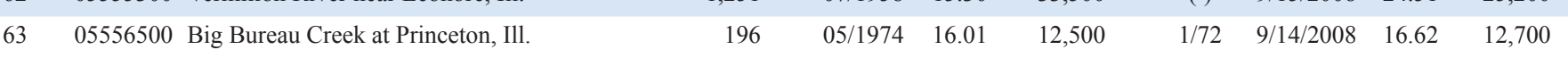

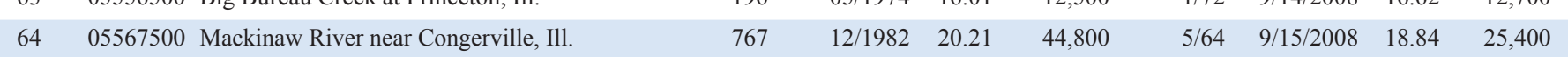

6505573540 Sangamon River at Route 48 at Decatur, III. $\quad \begin{array}{lllllllll}2 & 938 & 05 / 2002 & 24.33 & 131,800 & 2 / 26 & 9 / 14 / 2008 & 24.43 & 21,500\end{array}$

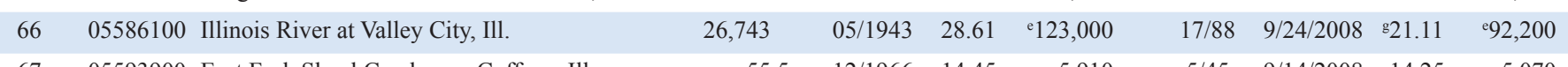

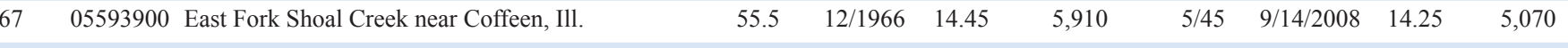

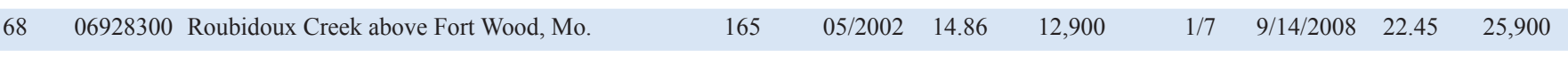

$69 \quad 06934500$ Missouri River at Hermann, Mo. $\quad \begin{array}{lllllllll}522,500 & 07 / 1993 & 36.97 & 750,000 & 24 / 82 & 9 / 15 / 2008 & 31.34 & 9350,000\end{array}$

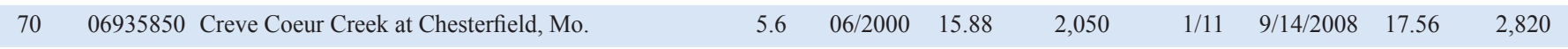

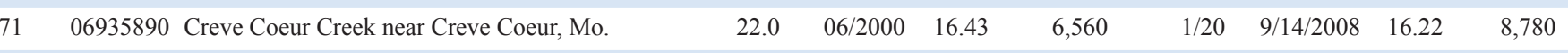

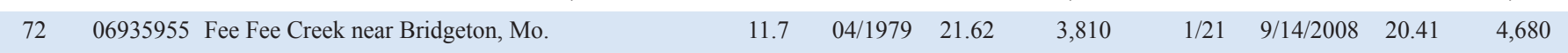

73006935965 Missouri River at St. Charles, Mo. $\quad \begin{array}{lllllllll}524,000 & 05 / 2002 & 31.69 & 350,000 & 1 / 8 & 9 / 16 / 2008 & 31.82 & 0353,000\end{array}$

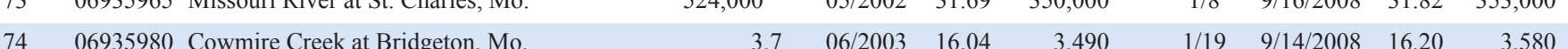

$\begin{array}{llllllllll}75 & 06936475 \text { Coldwater Creek near Black Jack, Mo. } & 40.4 & 04 / 2001 & 10.67 & 10,600 & 2 / 12 & 9 / 14 / 2008 & 15.62 & 9,690\end{array}$

$\begin{array}{ll}76 & 07005000 \\ 77\end{array}$

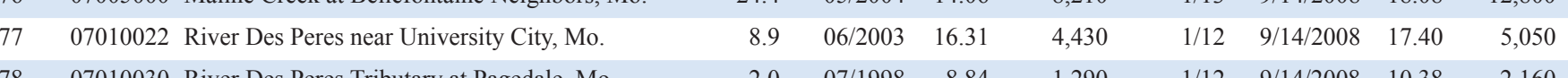

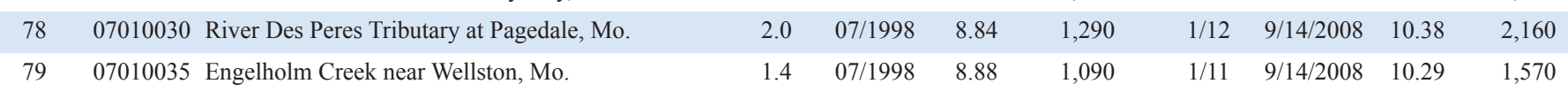

\begin{tabular}{|c|c|c|c|c|c|c|c|c|c|c|c|c|}
\hline \multirow{4}{*}{$\begin{array}{c}\text { Estimated } \\
\text { AEP for } \\
\text { observed } \\
\text { peak } \\
\text { streamflow } \\
\text { (percent) }\end{array}$} & \multicolumn{12}{|c|}{ Expected peak streamflows for selected AEP with 95-percent confidence limits $\left(\mathrm{ft}^{2} / \mathrm{s}\right)^{b}$} \\
\hline & \multicolumn{3}{|c|}{$\begin{array}{c}\text { 4-percent AEP } \\
\text { (25-year recurrence) }\end{array}$} & \multicolumn{3}{|c|}{$\begin{array}{c}\text { 2-percent AEP } \\
\text { (50--year recurrence) }\end{array}$} & \multicolumn{3}{|c|}{$\begin{array}{c}\text { 1-percent AEP } \\
\text { (100-year recurrence) }\end{array}$} & \multicolumn{3}{|c|}{$\begin{array}{l}\text { 0.2-percent AEP } \\
\text { (500-year recurrence) }\end{array}$} \\
\hline & \multirow{2}{*}{ Estimate } & \multicolumn{2}{|c|}{ Confidence limit } & \multirow{2}{*}{ Estimate } & \multicolumn{2}{|c|}{ Confidence limit } & \multirow{2}{*}{ Estimate } & \multicolumn{2}{|c|}{ Confidence limit } & \multirow{2}{*}{ Estimate } & \multicolumn{2}{|c|}{ Confidence limit } \\
\hline & & Low & High & & Low & High & & Low & High & & Low & High \\
\hline $0.2-1$ & 7,340 & 6,710 & 8,160 & 8,010 & 7,280 & 9,000 & 88,640 & 7,800 & 9,800 & 9,990 & 8,900 & 11,500 \\
\hline 4-10 & c871 & 741 & 1,090 & 9960 & 806 & 1,230 & ${ }^{1} 1,040$ & 867 & 1,360 & ${ }^{1} 1,230$ & 995 & 1,660 \\
\hline 4-10 & ${ }^{\circ 509}$ & 442 & 607 & c563 & 485 & 682 & ${ }^{\mathrm{c}} 614$ & 524 & 753 & ${ }^{\circ} 721$ & 604 & 908 \\
\hline $.2-1$ & 2,570 & 2,170 & 3,350 & 2,890 & 2,400 & 3,920 & ${ }^{c} 3,230$ & 2,620 & 4,550 & ${ }^{\circ} 4,080$ & 3,170 & 6,230 \\
\hline $2-4$ & $c^{3}, 100$ & 2,380 & 4,690 & ${ }^{c 3,730}$ & 2,780 & 5,990 & ${ }^{4}, 420$ & 3,200 & 7,540 & ${ }^{\circ} 6,340$ & 4,290 & 12,300 \\
\hline j.- & -- & -- & -- & -- & -- & -- & -- & -- & -- & -- & -- & -- \\
\hline $1-2$ & ${ }^{\circ}, 730$ & 4,110 & 5,650 & ${ }^{c 5,430}$ & 4,650 & 6,610 & ${ }^{\circ} 6,140$ & 5,190 & 7,620 & ${ }^{\circ 7,860}$ & 6,470 & 10,100 \\
\hline $4-10$ & ‘8,480 & 6,660 & 12,400 & ${ }^{\cdot} 10,100$ & 7,670 & 15,600 & ${ }^{`} 11,800$ & 8,730 & 19,200 & ${ }^{\prime} 16,400$ & 11,400 & 30,100 \\
\hline $.2-1$ & ${ }^{\circ} 1,340$ & 1,090 & 1,860 & ${ }^{\mathrm{c} 1,560}$ & 1,230 & 2,260 & ${ }^{c} 1,780$ & 1,380 & 2,710 & ${ }^{2} 2,370$ & 1,740 & 3,990 \\
\hline $1-2$ & ${ }^{{ }^{1}, 320}$ & 893 & 2,460 & ${ }^{\circ} 1,750$ & 1,130 & 3,570 & 2,260 & 1,390 & 5,040 & c3,900 & 2,160 & 10,500 \\
\hline $1-2$ & $c^{3}, 750$ & 2,940 & 5,510 & ${ }^{\circ}, 450$ & 3,390 & 6,930 & ${ }^{\circ 5,220}$ & 3,860 & 8,580 & ${ }^{\circ 7,310}$ & 5,070 & 13,500 \\
\hline $4-10$ & ${ }^{\circ}, 870$ & 3,900 & 6,900 & ${ }^{c 5,690}$ & 4,440 & 8,490 & ${ }^{\circ} 6,580$ & 5,000 & 10,300 & 8,930 & 6,410 & 15,600 \\
\hline 4-10 & ${ }^{{ }^{1}, 200}$ & 991 & 1,610 & ${ }^{`} 1,360$ & 1,110 & 1,920 & ${ }^{\circ} 1,540$ & 1,220 & 2,260 & ${ }^{\circ 1}, 990$ & 1,510 & 3,190 \\
\hline 4-10 & 2,980 & 2,310 & 4,450 & ${ }^{\circ}, 570$ & 2,680 & 5,650 & ${ }^{4}, 210$ & 3,070 & 7,070 & ${ }^{c 5}, 980$ & 4,090 & 11,400 \\
\hline 4-10 & ${ }^{`} 11,400$ & 8,660 & 17,600 & ${ }^{\top} 13,800$ & 10,200 & 22,800 & ‘16,600 & 11,800 & 29,000 & 24,200 & 16,100 & 48,500 \\
\hline 4-10 & 19,900 & 16,800 & 23,600 & 21,900 & 17,900 & 26,900 & 23,700 & 18,700 & 30,100 & 27,200 & 19,700 & 37,400 \\
\hline$>10$ & ${ }^{1} 1,860$ & 1,380 & 3,260 & $c^{2}, 190$ & 1,570 & 4,190 & $c_{2,560}$ & 1,770 & 5,300 & ${ }^{3}, 530$ & 2,270 & 8,750 \\
\hline $2-4$ & ${ }^{\circ}, 420$ & 1,110 & 2,100 & ${ }^{{ }^{1}, 690}$ & 1,280 & 2,650 & ${ }^{`} 1,990$ & 1,460 & 3,280 & ${ }^{2}, 790$ & 1,930 & 5,200 \\
\hline $1-2$ & 2,540 & 2,000 & 3,230 & 2,930 & 2,220 & 3,870 & 3,310 & 2,410 & 4,540 & 4,140 & 2,730 & 6,290 \\
\hline$>10$ & ${ }^{\circ} 3,650$ & 2,300 & 7,550 & ${ }^{\circ} 5,050$ & 3,010 & 11,600 & ${ }^{\circ} 6,820$ & 3,860 & 17,400 & ${ }^{\circ} 12,900$ & 6,450 & 41,100 \\
\hline $2-4$ & 442,100 & 30,900 & 68,800 & ${ }^{`} 52,000$ & 36,800 & 91,300 & ‘63,100 & 43,200 & 119,000 & 95,200 & 60,200 & 208,000 \\
\hline 4-10 & 30,700 & 25,600 & 36,900 & 35,000 & 28,300 & 43,400 & 39,100 & 30,500 & 50,200 & 48,200 & 34,400 & 67,500 \\
\hline $2-4$ & 11,500 & 9,470 & 14,100 & 13,100 & 10,400 & 16,600 & 14,600 & 11,000 & 19,200 & 17,700 & 12,200 & 25,800 \\
\hline $4-10$ & 29,600 & 22,500 & 38,900 & 35,800 & 26,000 & 49,300 & 42,200 & 29,300 & 60,900 & 57,800 & 35,900 & 93,200 \\
\hline j.- & -- & -- & -- & -- & - & -- & -- & -- & -- & -- & -- & -- \\
\hline$>10$ & 1110,000 & -- & -- & '121,000 & -- & -- & 132,000 & -- & -- & 157,000 & -- & -- \\
\hline 4-10 & 5,460 & 4,350 & 6,860 & 6,340 & 4,860 & 8,250 & 7,240 & 5,350 & 9,800 & 9,450 & 6,360 & 14,000 \\
\hline $1-2$ & $\mathrm{~m}_{2} 21,200$ & -- & -- & $\mathrm{m} 25,300$ & -- & - & $\mathrm{m}_{2} 29,700$ & - & - & ${ }^{\mathrm{m}} 40,300$ & -- & -- \\
\hline$>10$ & 533,000 & -- & -- & '604,000 & -- & -- & '673,000 & -- & -- & 1833,000 & -- & -- \\
\hline $.2-1$ & 2,370 & 1,800 & 3,120 & 2,530 & 1,900 & 3,360 & 2,680 & 1,990 & 3,610 & 2,990 & 2,190 & 4,090 \\
\hline $4-10$ & 9,470 & 6,900 & 13,000 & 12,500 & 8,760 & 17,700 & 16,000 & 10,900 & 23,400 & 26,500 & 17,200 & 40,700 \\
\hline $2-4$ & 4,650 & 3,800 & 5,680 & 5,200 & 4,160 & 6,500 & 5,740 & 4,500 & 7,320 & 6,950 & 5,260 & 9,170 \\
\hline$>10$ & 536,000 & -- & -- & '606,000 & -- & -- & '674,000 & -- & -- & 1829,000 & -- & -- \\
\hline $4-10$ & 3,890 & 3,120 & 4,840 & 4,290 & 3,310 & 5,550 & 4,590 & 3,420 & 6,170 & 5,020 & 3,490 & 7,230 \\
\hline 4-10 & 9,430 & 7,120 & 12,500 & 10,100 & 7,320 & 13,900 & 10,600 & 7,430 & 15,100 & 11,500 & 7,590 & 17,300 \\
\hline $4-10$ & 13,300 & 9,460 & 18,600 & 16,100 & 11,100 & 23,400 & 19,600 & 13,200 & 29,200 & 30,600 & 19,700 & 47,600 \\
\hline 4-10 & 5,150 & 4,050 & 6,560 & 5,530 & 4,150 & 7,380 & 5,890 & 4,210 & 8,240 & 6,640 & 4,230 & 10,400 \\
\hline $.2-1$ & 1,700 & 1,120 & 2,580 & 1,870 & 1,160 & 3,010 & 2,010 & 1,180 & 3,420 & 2,240 & 1,160 & 4,320 \\
\hline $2-4$ & 1,480 & 1,100 & 1,990 & 1,620 & 1,200 & 2,190 & 1,750 & 1,280 & 2,380 & 1,990 & 1,450 & 2,740 \\
\hline
\end{tabular}


Table 7. Summary of peak stages, streamflows, and flood-probability estimates for selected U.S. Geological Survey streamgages during September 2008.-Continued

[mi², square mile; ft, foot; ff/s, cubic foot per second; AEP, annual exceedance probability; <, less than; --, no data; Br., Branch; >, greater than]

Flood data

\begin{tabular}{|c|c|c|c|c|c|c|c|c|c|c|}
\hline \multirow{3}{*}{$\begin{array}{c}\text { Site } \\
\text { number } \\
\text { (fig. 16) }\end{array}$} & \multirow{3}{*}{$\begin{array}{l}\text { Station } \\
\text { number }\end{array}$} & \multirow{3}{*}{ Station name } & \multirow{3}{*}{$\begin{array}{l}\text { Contributing } \\
\text { drainage } \\
\text { area } \\
\text { (mi') }\end{array}$} & \multicolumn{7}{|c|}{ Flood data } \\
\hline & & & & \multicolumn{3}{|c|}{ Previous maximum streamflow } & \multicolumn{4}{|c|}{ Flood of September 2008} \\
\hline & & & & Date & $\begin{array}{l}\text { Stage } \\
\text { (tit) }\end{array}$ & $\begin{array}{c}\text { Streamflow } \\
\left(\mid t^{2} / \mathbf{s}\right)\end{array}$ & $\begin{array}{l}\text { Rank"/ } \\
\text { annual } \\
\text { peaks }\end{array}$ & Date & 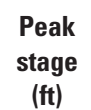 & $\begin{array}{c}\text { Peak } \\
\text { streamallow } \\
\text { (ttr/s) }\end{array}$ \\
\hline 80 & 07010086 & Deer Creek at Maplewood, Mo. & 36.5 & $07 / 2004$ & 16.57 & 5,560 & $1 / 13$ & 9/14/2008 & 21.53 & 10,300 \\
\hline 81 & 07010090 & MacKenzie Creek near Shrewsbury, Mo. & 3.5 & 06/1998 & 10.80 & 1,730 & $1 / 12$ & 9/14/2008 & 11.36 & 1,970 \\
\hline 82 & 07010180 & Gravois Creek near Mehlville, Mo. & 18.1 & 09/2003 & 16.66 & 4,450 & $1 / 12$ & 9/14/2008 & 19.17 & 5,870 \\
\hline 83 & 07010208 & Martigney Creek near Arnold, Mo. & 2.6 & $07 / 2006$ & 13.31 & 1,710 & $1 / 10$ & 9/14/2008 & 14.67 & 2,120 \\
\hline 84 & 07015720 & Bourbeuse River near High Gate, Mo. & 135 & 12/1982 & 23.65 & 49,300 & $3 / 45$ & 9/14/2008 & 24.38 & 38,800 \\
\hline 85 & 07019317 & Mattese Creek near Mattese, Mo. & 7.9 & $07 / 2006$ & 13.93 & 6,560 & $1 / 13$ & 9/14/2008 & 16.71 & 10,700 \\
\hline 86 & 07053810 & Bull Creek near Walnut Shade, Mo. & 191 & 05/2002 & 14.41 & 32,200 & $3 / 12$ & 9/14/2008 & 16.38 & 25,900 \\
\hline 87 & 07144550 & Arkansas River at Derby, Kans. & 33,567 & 11/1998 & 16.45 & 58,300 & $7 / 40$ & 9/13/2008 & 15.19 & 37,100 \\
\hline 88 & 07145700 & Slate Creek at Wellington, Kans. & 154 & 06/1975 & 25.82 & 28,500 & $2 / 49$ & 9/13/2008 & 24.28 & 14,100 \\
\hline 89 & 07146500 & Arkansas River at Arkansas City, Kans. & 36,106 & $06 / 1923$ & 28.43 & 103,000 & 4/91 & 9/14/2008 & 27.53 & i 79,100 \\
\hline 90 & 07151000 & Salt Fork Arkansas River at Tonkawa, Okla. & 4,520 & 10/1973 & 28.98 & 97,300 & $4 / 77$ & $9 / 15 / 2008$ & 25.60 & 4 47,300 \\
\hline 91 & 07151500 & Chikaskia River near Corbin, Kans. & 794 & 06/1923 & 28.00 & 60,000 & $6 / 50$ & 9/13/2008 & 20.07 & 27,100 \\
\hline 92 & 07152000 & Chikaskia River near Blackwell, Okla. & 1,859 & $06 / 1923$ & 37.00 & ${ }^{\bullet} 100,000$ & 4/75 & 9/14/2008 & 35.36 & ${ }^{\circ} 66,500$ \\
\hline 93 & 07260000 & Dutch Creek at Waltreak, Ark. & 81.4 & $07 / 1969$ & 22.38 & 24,500 & $\mathrm{~d}$ & $9 / 3 / 2008$ & 19.61 & 21,000 \\
\hline 94 & 07361500 & Antoine River at Antoine, Ark. & 178 & 05/1905 & 29.70 & 40,000 & 6/71 & 9/3/2008 & 26.64 & 25,300 \\
\hline 95 & 07363000 & Saline River at Benton, Ark. & 550 & $04 / 1927$ & 30.50 & 110,000 & $3 / 80$ & 9/3/2008 & 29.27 & 194,800 \\
\hline
\end{tabular}
$\begin{array}{llllllll}550 & 04 / 1927 & 30.50 & 110,000 & 3 / 80 & 9 / 3 / 2008 & 29.27 & 94,800\end{array}$ a Rank of the maximum instantaneous peak streamflow measured during September 2008 compared
indicates that the September 2008 peak streamflow was higher than all other recorded annual peaks.

${ }^{b}$ Unless otherwise noted, expected peak streamflows are based on Water Resources Council Bulletin 17B weighting by variance method.

${ }^{\circ}$ Expected peak streamflows based on Bulletin 17B systematic frequency-curve estimate only.

${ }^{\circledR}$ The peak streamflow for September 2008 was exceded by another peak streamflow dining 2008 .

' Streamflow affected to unknown degree by regulation or diversion.

${ }^{\mathrm{r}}$ Estimated.

A higher stage exists that corresponds to a streamflow that is less than the peak streamflow.

hAll or part of the record affected by urbanization, mining, agricultural changes, channelization, or other

Streamflow affected by regulation or diversion.

Estimated AEP uncharacterized because of regulation, diversion, or insufficient data.

${ }^{k}$ Streamflow affected by dam failure.

U.S. Army Corps of Engineers (2004).

${ }^{m}$ Expected peak streamflows are based on regional regression equation estimates only.

\begin{tabular}{|c|c|c|c|c|c|c|c|c|c|c|c|c|}
\hline \multirow{4}{*}{$\begin{array}{l}\text { Estimated } \\
\text { AEP for } \\
\text { observed } \\
\text { peak } \\
\text { streamflow } \\
\text { (percent) }\end{array}$} & \multicolumn{12}{|c|}{$t / \mathbf{s}\}$} \\
\hline & \multicolumn{3}{|c|}{$\begin{array}{c}\text { 4-percent AEP } \\
\text { (25-year recurrence) }\end{array}$} & \multicolumn{3}{|c|}{$\begin{array}{c}\text { 2-percent AEP } \\
\text { (50-year recurrence) }\end{array}$} & \multicolumn{3}{|c|}{$\begin{array}{c}\text { 1-percent AEP } \\
\text { (100-year recurrence) }\end{array}$} & \multicolumn{3}{|c|}{$\begin{array}{c}\text { 0.2-2percent AEP } \\
\text { (500-year recurrence) }\end{array}$} \\
\hline & \multirow{2}{*}{ Estimate } & \multicolumn{2}{|c|}{ Confidence limit } & \multirow{2}{*}{ Estimate } & \multicolumn{2}{|c|}{ Confidence limit } & \multirow{2}{*}{ Estimate } & \multicolumn{2}{|c|}{ Confidence limit } & \multirow{2}{*}{ Estimate } & \multicolumn{2}{|c|}{ Confidence limit } \\
\hline & & Low & High & & Low & High & & Low & High & & Low & High \\
\hline$<.2$ & 7,570 & 5,240 & 11,000 & 7,880 & 5,270 & 11,800 & 8,100 & 5,280 & 12,400 & 8,500 & 5,350 & 13,500 \\
\hline $4-10$ & 2,010 & 1,570 & 2,580 & 2,110 & 1,560 & 2,840 & 2,180 & 1,550 & 3,060 & 2,290 & 1,520 & 3,430 \\
\hline $.2-1$ & 5,170 & 4,040 & 6,620 & 5,450 & 4,180 & 7,120 & 5,720 & 4,310 & 7,580 & 6,280 & 4,630 & 8,510 \\
\hline $2-4$ & 2,100 & 1,590 & 2,770 & 2,330 & 1,750 & 3,100 & 2,560 & 1,900 & 3,440 & 3,070 & 2,250 & 4,190 \\
\hline $1-2$ & 33,700 & 26,800 & 42,400 & 37,700 & 28,900 & 49,200 & 41,200 & 30,400 & 55,800 & 48,900 & 33,400 & 71,800 \\
\hline$<.2$ & 7,730 & 5,760 & 10,400 & 8,400 & 6,220 & 11,300 & 9,050 & 6,660 & 12,300 & 10,500 & 7,660 & 14,500 \\
\hline $4-10$ & 33,000 & 21,100 & 51,600 & 39,600 & 24,700 & 63,300 & 46,400 & 28,500 & 75,700 & 62,900 & 36,900 & 107,000 \\
\hline$>10$ & ${ }^{\circ 55,800}$ & 42,600 & 80,400 & ${ }^{\circ} 70,100$ & 52,000 & 105,000 & 886,000 & 66,200 & 135,000 & ${ }^{\circ} 130,000$ & 89,100 & 223,000 \\
\hline $4-10$ & 15,000 & 11,200 & 20,200 & 18,500 & 13,100 & 26,000 & 22,200 & 15,000 & 32,900 & -- & -- & -- \\
\hline 4-10 & 881,200 & 66,200 & 104,000 & ‘99,700 & 80,000 & 131,000 & ${ }^{\circ} 119,000$ & 94,100 & 159,000 & ${ }^{\circ} 168,000$ & 129,000 & 234,000 \\
\hline 4-10 & ${ }^{\circ 50,600}$ & 40,000 & 67,700 & ${ }^{\circ} 61,500$ & 47,800 & 84,400 & ${ }^{\circ} 72,700$ & 55,600 & 102,000 & ${ }^{\circ} 100,000$ & 73,900 & 147,000 \\
\hline $4-10$ & 35,800 & 28,000 & 45,900 & 43,600 & 32,600 & 58,300 & 51,700 & 36,900 & 72,400 & -- & -- & -- \\
\hline $4-10$ & 72,900 & 54,900 & 96,900 & 90,800 & 65,600 & 126,000 & 110,000 & 76,100 & 160,000 & 163,000 & 101,000 & 263,000 \\
\hline $1-2$ & 17,800 & 14,300 & 22,200 & 21,200 & 16,400 & 27,500 & 24,600 & 18,200 & 33,200 & 33,400 & 22,300 & 50,000 \\
\hline $4-10$ & 26,800 & 22,400 & 32,100 & 30,300 & 24,400 & 37,500 & 33,700 & 26,300 & 43,200 & 41,800 & 29,900 & 58,500 \\
\hline $1-2$ & 79,600 & 64,800 & 97,600 & 93,700 & 73,600 & 119,000 & 108,000 & 81,700 & 143,000 & 144,000 & 98,600 & 209,000 \\
\hline
\end{tabular}
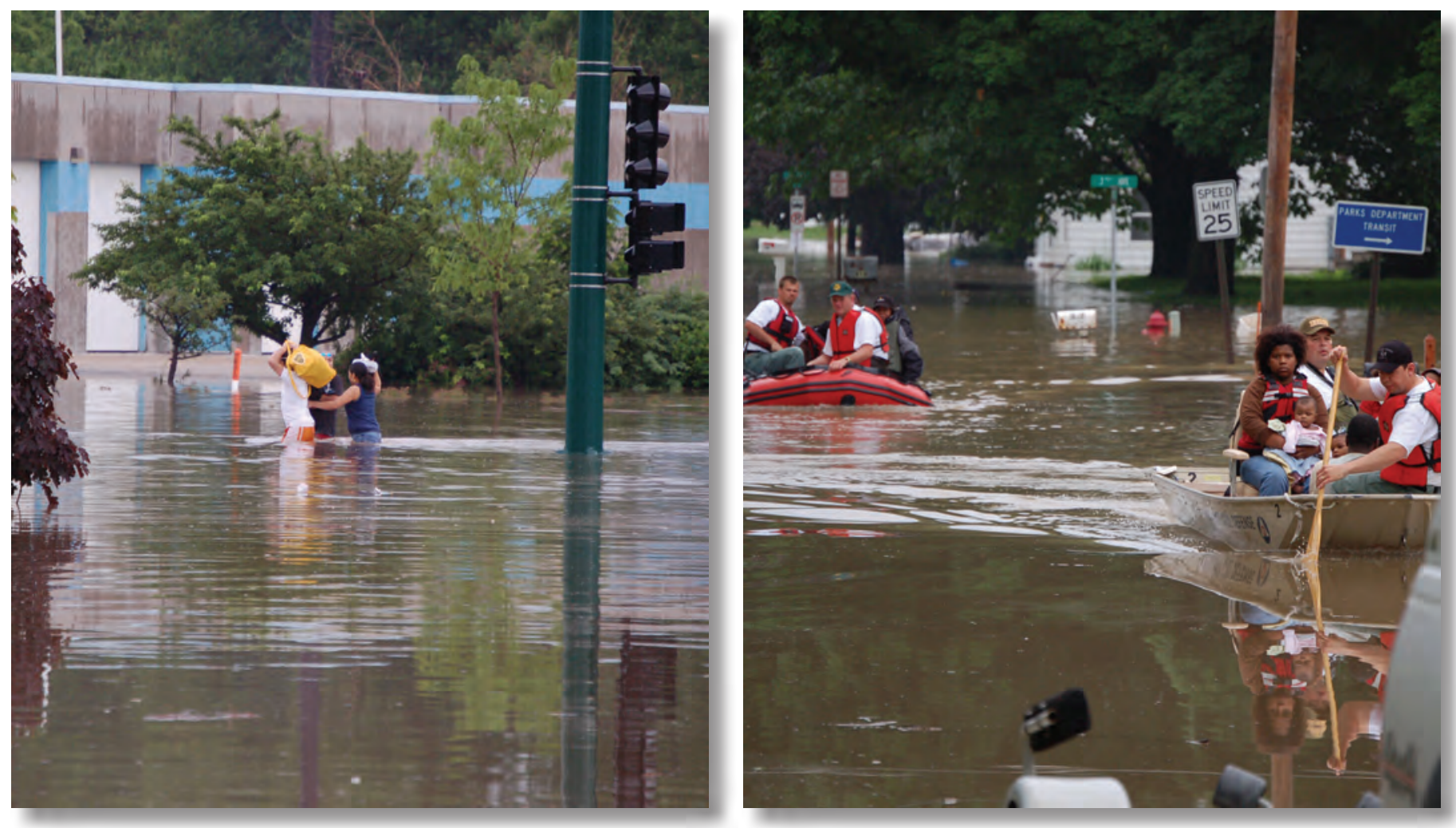
USGS hydrographer installing a temporary streamgage in the town of Cedar Rapids, lowa along Interstate 380. The Cedar River at Cedar Rapids, lowa (USGS streamgage 05464500) main streamgage was inundated by the flood. Photograph by Jason McVay, USGS.
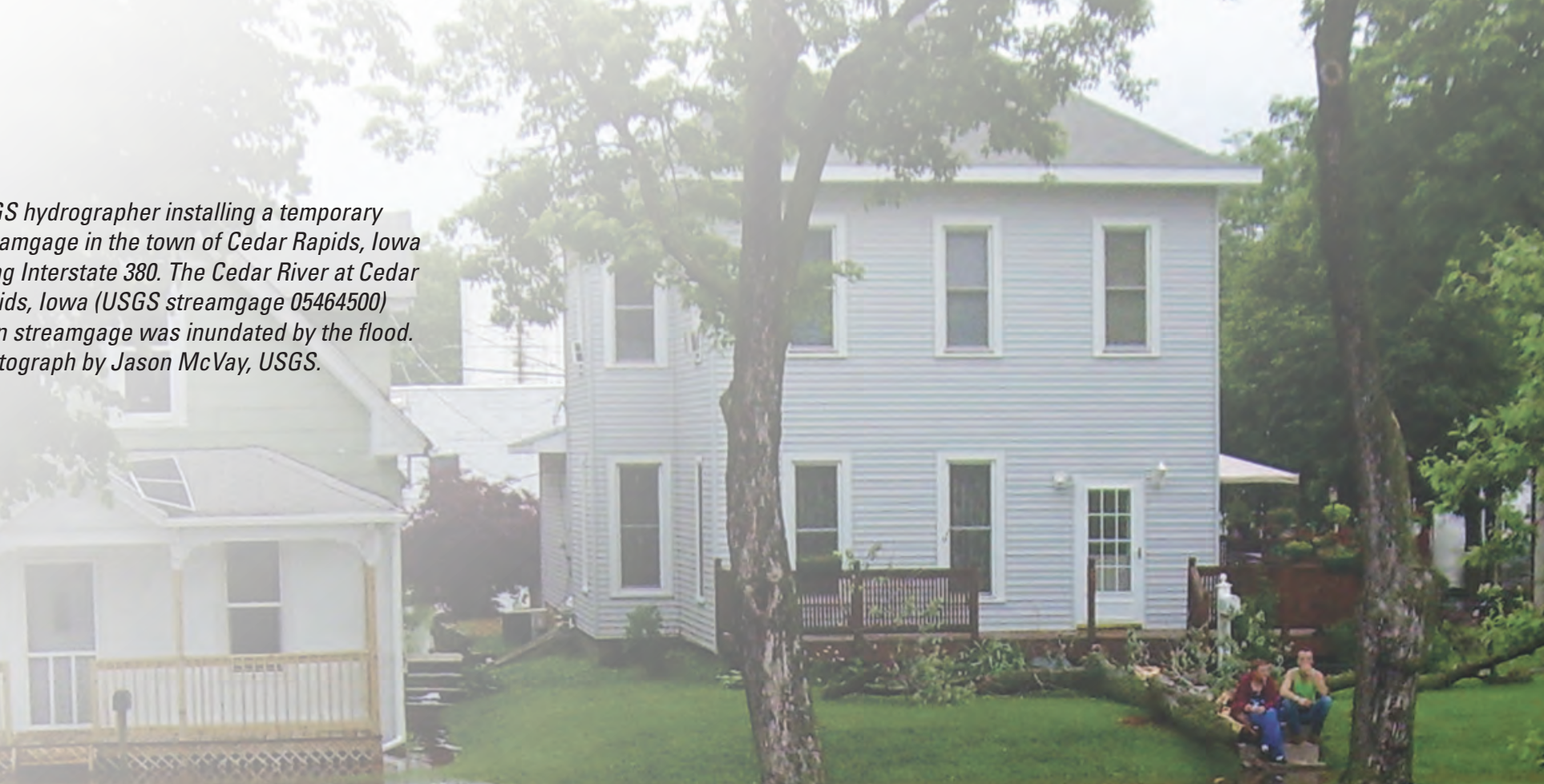

if
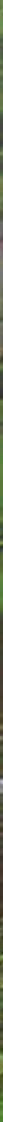

Publishing support provided by:

Rolla and Denver Publishing Service Centers

For more information concerning this publication, contact: Chief, USGS Office of Surface Water 415 National Center

12201 Sunrise Valley Drive Reston, VA 20192

(703) 648-5301

Or visit the Office of Surface Water Web site at: http://water.usgs.gov/osw/ 


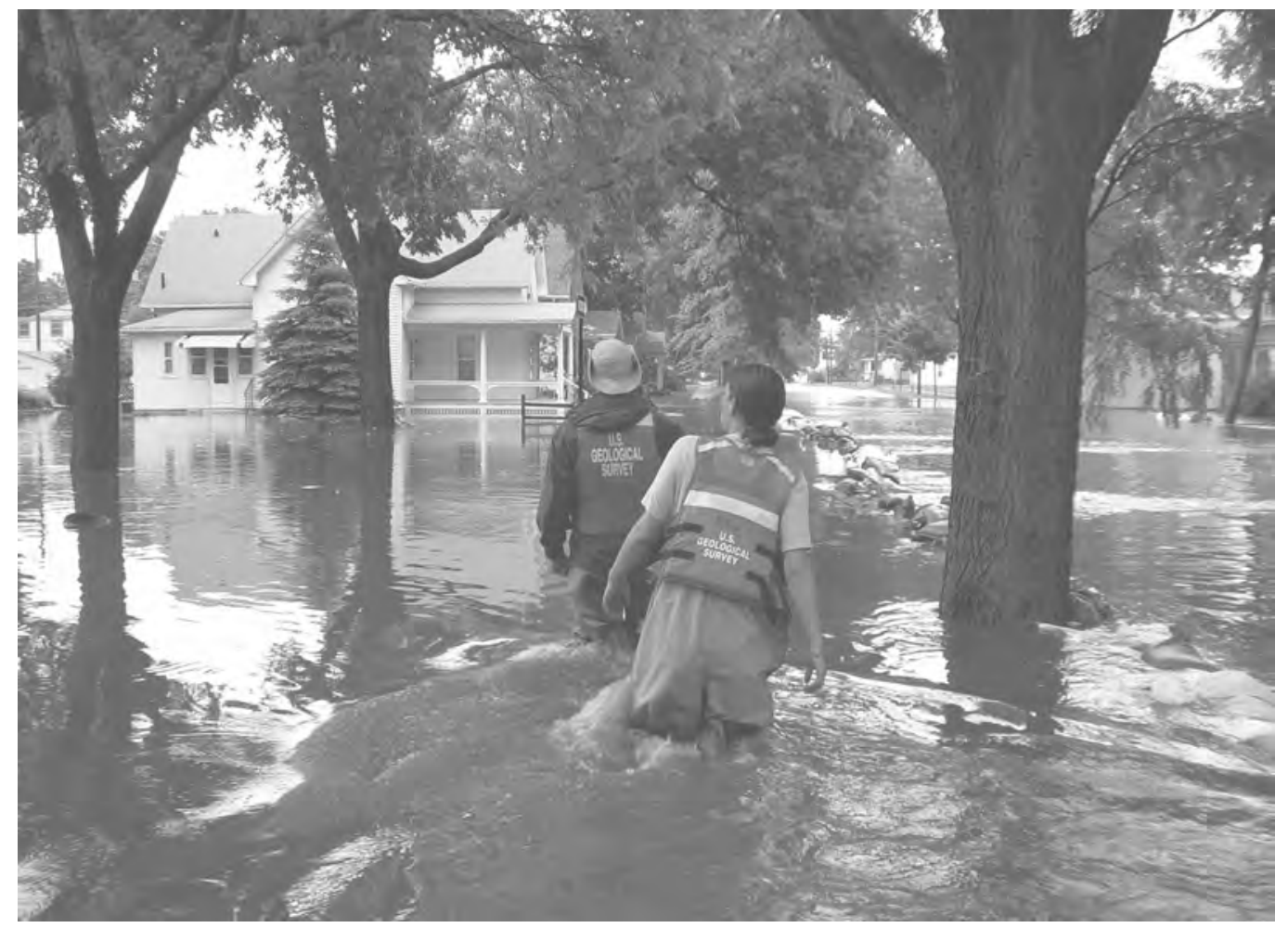

Back cover.

USGS hydrographers wade through the flooded streets of Cedar Rapids, lowa to access streamgage on the Cedar River at Cedar Rapids, lowa (USGS streamgage 05464500). Photograph by Scott Strader, USGS. 


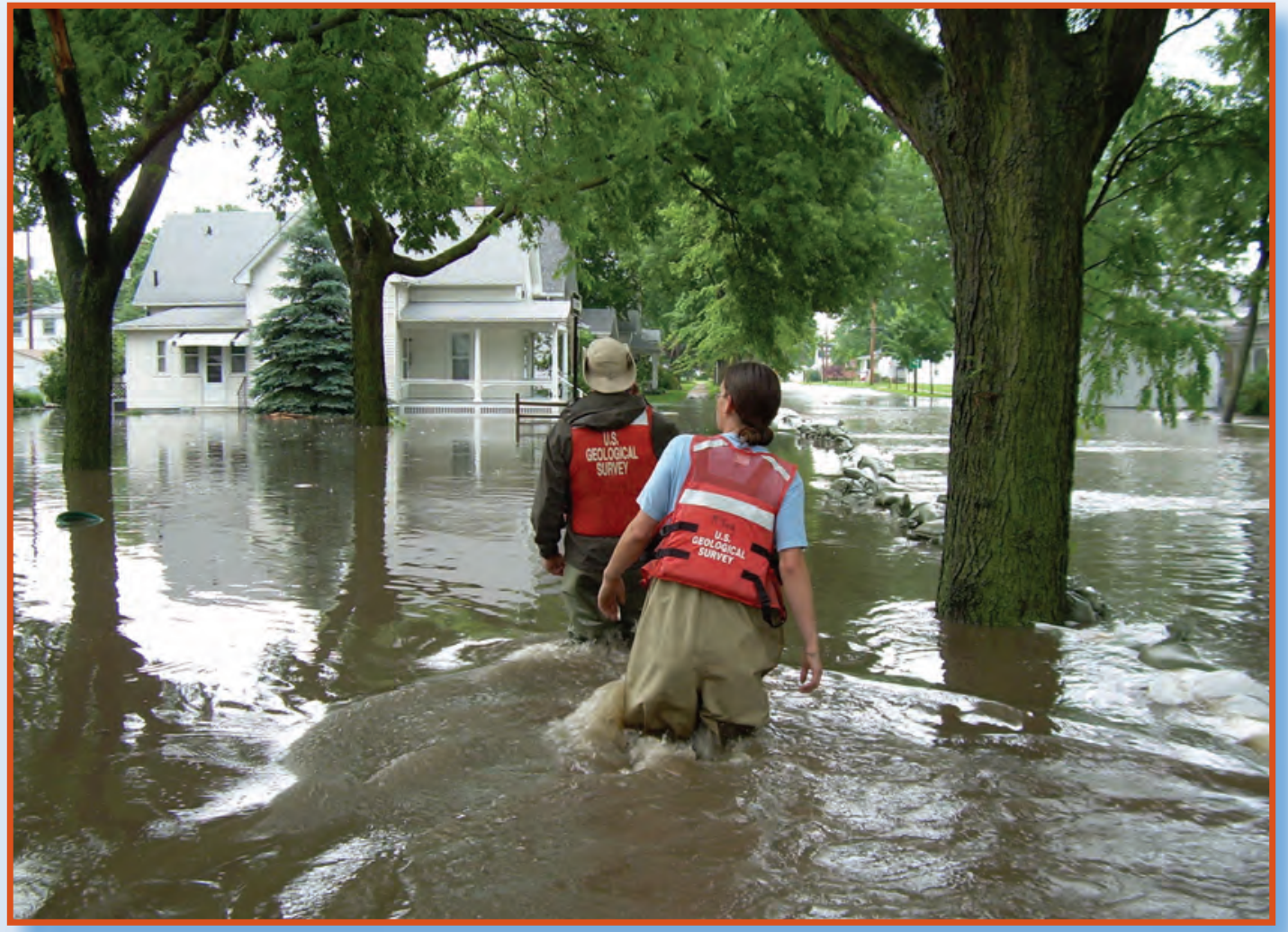

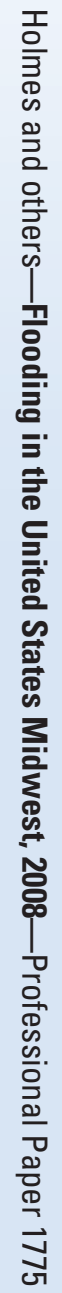

